\title{
ANALISIS EFEKTIFITAS-BIAYA ANTARA KOMBINASI SALBUTAMOL-IPRATROPIUM DENGAN SALBUTAMOL PADA SERANGAN ASMA
}

\author{
Amelia Lorensia*, Ferdias Kurnia Bahari \\ Fakultas Farmasi, Universitas Surabaya \\ *amelia.1orensia@gmail.com
}

\begin{abstract}
ABSTRAK
Pengobatan serangan asma merupakan perlu mendapatkan perhatian untuk mendapatkan pengobatan yang efektif dan efisien. Lini pertama dari pengobatan serangan asma adalah salbutamol nebulasi, namun beberapa pengobatan asma membutuhkan tambahan kombinasi ipratropium. mengetahui cost-effectiveness dengan penggunaan kombinasi salbutamol dan ipratropium bromide dengan salbutamol tunggal terhadap perbaikan gejala asma dan lama perawatan pada pasien serangan asma. Desain penelitian menggunakan retrospektif dari data rekam medis pasien asma di suatu RS di Surabaya pada periode Januari-Oktober 2017. Variabel tergantung adalah biaya dan outcome klinis (lama perawatan dan hilangnya gejala sesak). Analisa data yang digunakan adalah perhitungan ACER dan uji beda. Subjek penelitian sebanyak 64 orang, yang terdiri dari 23 orang kelompok A (salbutamol-ipratropium) dan 41 orang dari kelompok B (salbutamol). Kelompok A lebih cost-effective dalam lama perawatan dan trade-off dalam menurunkan gejala asma dibandingkan kelompok B. Tidak ada perbedaan signifikan antara biaya $(p(0,816)>0,05))$, lama perawatan $(p=0,386)>0,05))$ dan perbaikan gejala asma $(p(0,676)>0,05)$. Oleh karena itu perlu dilakukan penelitian lebih lanjut pada tingkat serangan asma lainnya dan komponen biaya/outcome lainnya.
\end{abstract}

Kata kunci: analsiis efektifitas-biaya, ipratropium, salbutamol, serangan asma

\section{ABSTRACT}

Treatment of asthma exacerbation is necessary to get attention to get effective and efficient treatment. The first line of treatment for asthma exacerbation is nebulation salbutamol, but some asthma treatments require additional combinations of ipratropium. know the cost-effectiveness with the use of a combination of salbutamol and ipratropium bromide with salbutamol alone to improve asthma symptoms and length of treatment in patients with asthma attacks. The study design was retrospective from medical record data of asthma patients in a hospital in Surabaya in the period from January-October 2017. Dependent variables were cost and clinical outcome (duration of treatment and loss of breathless symptoms). Data analysis used was ACER calculation and different test. The subjects were 64 people, consisting of 23 people in group A (salbutamolipratropium) and 41 people in group B (salbutamol). Group A was more costeffective in length of treatment and trade-off in reducing asthma symptoms than in group $B$. There was no significant difference between costs $(p(0.816)>0.05)$, length of treatment $(p=0.386)>0.05))$ and improvement of asthma symptoms $(p(0.676)>$ 0.05). Therefore, further research was needed on the level of other asthma attacks and other cost/outcome components. 
Jurnal Insan Farmasi Indonesia, 3(1) Mei 2020 (38-49)

Amelia Lorensia

p-ISSN 2621-3184 ; e-ISSN 2621-4032

Keywords: asthma exacerbation, cost-effectiveness analysis, ipratropium, salbutamol

\section{PENDAHULUAN}

Di Indonesia, prevalensi asma diperkirakan sebesar $\quad 3,32 \%$ sedangkan prevalensi asma di propinsi Jawa Timur sebesar $2,62 \%{ }^{1}$. Penatalaksanaan asma di rumah sakit biasanya dialami pada pasien yang mengalami serangan asma. Serangan asma adalah perburukan akut atau subakut pada gejala dan fungsi paru dari kondisi status asma pasien yang biasanya ${ }^{2}$. Penggunaan terapi di rumah sakit dengan berbagai macam pengobatan asma dapat menimbulkan drug related problem (DRP), seperti permasalahan keamanan ${ }^{3,4,5}$ dan efektifitas $^{6} \quad$ aminofilin yang merupakan obat rentang terapi sempit, beta- 2 agonis yang merupakan terapi lini pertama ${ }^{5,7}$, kortikosteroid dengan dosis besar ${ }^{8}$. Serangan asma merupakan penyebab terbesar pasien masuk ke IGD. Di Amerika, kejadiannya mencapai 67 dari 10,000 pada tahun $2002^{9}$.

Penelitian sebelumnya oleh Lorensia et al. ${ }^{10}$, menyatakan pengobatan tidak diperlukan pada pasien asma bronkial mencapai $\mathrm{Rp}$. $23,991,039.20$ dan biaya terapi obat pasien asma bronkial lebih mahal dari yang diperlukan mencapai Rp. 4,640,488.00 artinya banyak terapi yang tidak perlu diberikan, bila biaya obat tidak efisien maka dampak negatifnya kepada pasien yang harus mengeluarkan biaya lebih untuk pengobatan. Selain itu, makin banyak terapi yang digunakan pasien maka meningkatkan risiko DRP ${ }^{11,12}$.

Apoteker sebagai salah satu tenaga kesehatan, berperan penting dalam pengobatan asma, termasuk dalam mengidentifikasi dan mencegah DRP. Pertimbangan rasionalitas pengobatan kini meliputi efisien dan efektivitas terapi. Efisien dalam hal ini akan sangat melibatkan biaya, baik berupa uang, waktu, barang, dan jasa. Oleh karena itu, perlu dilakukan penelitian farmakoekonomi yang berfungsi untuk mendeksripsikan dan menganalisis biaya terapi obat atau biaya pengobatan dalam pelayanan kesehatan pada suatu sistem kesehatan yang luas dan pada masyarakat, salah satunya yaitu di rumah sakit ${ }^{13}$.

Penelitian pendahuluan menunjukkan ada dua terapi bronkodilator yang paling banyak digunakan untuk penanganan serangan 
Jurnal Insan Farmasi Indonesia, 3(1) Mei 2020 (38-49)

Amelia Lorensia

p-ISSN 2621-3184 ; e-ISSN 2621-4032

asma, yaitu salbutamol inhalasi tunggal dan kombinasi salbutamolipraptropium. Kedua terapi tersebut masuk dalam pedoman pengobatan asma $^{2}$. Lini pertama pada pengobatan asma tingkat ringan-sedang adalah beta-2 agonis aksi cepat inhalasi, umumnya yang digunakan di rumah sakit di Indonesia adalah salbutamol inhalasi ${ }^{8,14,15}$. Salbutamol dapat memberikan efek relaksasi otot polos saluran pernafasan untuk mengurangi gejala serangan asma. Namun, apabila terapi salbutamol tunggal belum memberikan efek yang optimal maka dapat ditambah ipraptropium, suatu antikolinergik yang akan menghambat refleks vagal dengan menghambat kerja asetilkolin. Kombinasi salbutamol dan ipratropium bromide bermanfaat pada serangan asma dengan tingkat keparahan sedang ${ }^{2}$. Penelitian lain oleh Kirkland et al. ${ }^{16}$, menyatakan secara keseluruhan, pasien yang menerima terapi kombinasi salbutamol dan antikolinergik inhalasi diperkirakan 65 pasien lebih sedikit per 1000 akan membutuhkan rawat inap setelah menerima terapi dibandingkan 231 per
1000 pasien yang menerima salbutamol saja. Meskipun terapi kombinasi salbutamol lebih efektif daripada salbutamol saja dalam mengurangi rawat inap pada peserta dengan serangan asma berat, tapi tidak ditemukan pada peserta serangan asma ringan-sedang $(\mathrm{P}=0,02)$.

Tujuan penelitian ini untuk mengetahui cost-effectiveness dengan penggunaan kombinasi salbutamol dan ipratropium bromide dengan salbutamol tunggal terhadap perbaikan gejala asma dan lama perawatan pada pasien serangan asma yang mendapatkan terapi awal di IGD suatu RS (rumah sakit) di Surabaya.

\section{METODE PENELITIAN}

\section{Desain Penelitian}

Desain penelitian ini menggunakan retrospektif dari data rekam medis pasien asma di suatu RS di Surabaya pada periode JanuariOktober 2017 (Nomor uji etik: 070/276/03.2/2017). Variabel tergantung adalah biaya dan outcome klinis (lama perawatan dan hilangnya gejala sesak). Nomor ijin pengambilan data dari RS No. 070/276/03.2/2017. 
Jurnal Insan Farmasi Indonesia, 3(1) Mei 2020 (38-49)

Amelia Lorensia

p-ISSN 2621-3184 ; e-ISSN 2621-4032

\section{Outcome}

Pada penelitian ini menggunakan outcome berupa lama perawatan di IGD Rumah Sakit (dalam satuan menit) dan perbaikan/hilangnya gejala dari sesak. Perbaikan/hilangnya gejala asma adalah keluhan akhir pasien yang tercatat di rekam medik berupa masih terasa sesak atau tidak.

\section{Populasi dan Sampel Penelitian}

Populasi dalam penelitian ini adalah pasien serangan asma di RS tersebut. Populasi target dalam penelitian ini adalah pasien serangan asma periode Januari 2017-Oktober 2017. Sampel (subjek) yang digunakan dalam penelitian ini adalah pasien asma melalui rekam medis yang memenuhi kriteria inklusi dan kriteria eksklusi. Kriteria inklusi antara lain: usia 17-45 tahun, tingkat keparahan serangan asma ringansedang. Kriteria eksklusi antara lain: pasien yang keluar rumah sakit dengan pulang paksa atau dirujuk ke rumah sakit lain atau meninggal; dan memiliki penyakit penyerta yang dapat mempengaruhi variabel tergantung penelitian (diabetes mellitus, tuberkulosis, ISPA (Infeksi
Saluran Pernafasan Atas), status asmatikus, kanker, dan penyakit jantung koroner). Pengumpulan subjek dalam penelitian ini menggunakan purposive sampling.

\section{Metode Pengumpulan Data}

Penelitian ini menggunakan data sekunder dari data rekam medis periode Januari-Agustus 2017 yang memenuhi kriteria subjek penelitian. Data tersebut kemudian direkap dalam lembar pengumpulan data.

\section{Analisa Data}

Dilakukan perhitungan ACER untuk mengetahui pengobatan yang cost-effective dengan masing-masing outcome klinis yaitu lama pengobatan di IGD dan perbaikan (hilangnya) gejala asma. Selain itu, juga dilakukan uji perbedaan besar biaya, lama pengobatan di IGD, dan perbaikan (hilangnya) gejala asma pada serangan asma dengan t-test bebas (parametrik) atau uji Mann Whitney (nonparametrik).

\section{HASIL DAN PEMBAHASAN}

\section{Karakteristik Subjek Penelitian}

Berdasarkan data rekam medik, pasien serangan asma sebanyak 342 pasien, dari 342 pasien, dan yang 
Jurnal Insan Farmasi Indonesia, 3(1) Mei 2020 (38-49)

Amelia Lorensia

p-ISSN 2621-3184 ; e-ISSN 2621-4032

sesuai dengan kriteria inklusi dan kelompok tidak terdistribusi normal eksklusi sebanyak 64 pasien. Data pada data kelompok $\mathrm{A}(\mathrm{P}=0,023)$, data karakteristik kedua kelompok dapat dilihat pada tabel 1. Sebagian besar subjek penelitian adalah perempuan pada masing-masing kelompok. Sebagian besar subjek dirawat di IGD saja dan gejala asma dapat tertangani, tanpa membutuhkan perawatan lebih lanjut di rawat inap,. Hanya satu orang dari masing-masing kelompok yang mendapatkan perawatan di rawat inap karena tidak mengalami perbaikan gejala asma. Dari hasil uji perbedaan karakteristik antar kelompok menunjukkan bahwa distribusi jenis kelamin, usia dan kedua outcome tidak ada perbedaan antara kelompok A dan B. Sedangkan distribusi karakteristik pekerjaan kedua kelompo subjek ada perbedaan yang signifikan (tabel 1).

Selain terapi yang dibandingkan, ada beberapa terapi lain yang juga digunakan subjek penelitian, seperti bronkodilator, kortiokosteroid, dan infus (tabel 2).

Berdasarkan uji normalitas dengan shapiro-wilk (jumlah masingmasing sampel tiap kelompok <50), menunjukkan data biaya dari kedua kelompok $\mathrm{B}(\mathrm{P}=0,002)$. Berdasarkan tabel 3, terlihat bahwa tidak ada perbedaan bermakna antara sebaran data biaya kelompok A dan B. Bahkan pada data alat kesehatan, tenaga kesehatan, dan biaya kamar antara kedua kelompok tidak ada perbedaan signifikan $(\mathrm{p}(0,816)>0,05)$.

\section{Biaya}

Data uji normalitas dari outcome klinis berupa lama perawatan di IGD ( $\mathrm{P}=0,226)$, dan Kelompok A dan Data Outcome Klinis lama perawatan di IGD Kelompok B $(\mathrm{P}=0,001)$, yang berarti data tidak terdistribus normal (non parametrik). Uji selanjutnya adalah uji perbedaan menggunakan mann whitney $u$ dengan nilai $p$ untuk lama peobatan di rumah sakit adalah 0,386 dan perbaikan gejala asma sebesar 0,676, yang artinya tidak ada perbedaan yang signifikan antara kelompok A dan B (tabel 4).

Penentuan biaya penelitian ini menggunakan pendekatan bottom-up yaitu, menggunakan aktivitas rinci dan data penggunaan input dari catatatn (penggunaan yang teramati) pada 
Jurnal Insan Farmasi Indonesia, 3(1) Mei 2020 (38-49)

Amelia Lorensia

p-ISSN 2621-3184; e-ISSN 2621-4032

tingkat penyedia layanan untuk bromida sebesar Rp. 253.854,00 dan memperkirakan biaya unit ${ }^{17,18,19}$. rata-rata biaya medis langsung Berdasarkan biaya medis langsung kelompok B yaitu salbutamol tunggal rata-rata dari kelompok A yaitu sebesar 257.386,00.

kombinasi salbutamol dan ipratropium

Tabel I. Distribusi Frekuensi Karakteristik Subjek Penelitian

\begin{tabular}{|c|c|c|c|c|c|c|}
\hline \multicolumn{2}{|c|}{$\begin{array}{c}\text { Karakteristik Subjek } \\
\text { Penelitian }\end{array}$} & \multicolumn{2}{|c|}{$\begin{array}{c}\text { Kelompok A } \\
\text { (n: 23) }\end{array}$} & \multicolumn{2}{|c|}{$\begin{array}{c}\text { Kelompok B } \\
(\mathrm{n}: 41)\end{array}$} & \multirow{2}{*}{$\begin{array}{c}\text { Uji perbedaan } \\
\text { karakter antar } \\
\text { kelompok } \\
\text { (Nilai P) } \\
\end{array}$} \\
\hline & & Frekuensi & $\begin{array}{c}\text { Prosentase } \\
(\%)\end{array}$ & Frekuensi & $\begin{array}{c}\text { Prosentase } \\
(\%)\end{array}$ & \\
\hline \multirow[t]{2}{*}{ Jenis Kelamin } & Laki-laki & 11 & 17,18 & 15 & 23,44 & 0,129 \\
\hline & Perempuan & 12 & 18,75 & 26 & 40,62 & \\
\hline \multirow[t]{3}{*}{ Usia (tahun) } & $17-25$ & 13 & 20,31 & 11 & 17,18 & 0,074 \\
\hline & $26-35$ & 4 & 6,25 & 11 & 17,18 & \\
\hline & $36-45$ & 6 & 9,37 & 19 & 29,68 & \\
\hline Outcome Klinis: & $\leq 1$ hari & 22 & 34,37 & 40 & 62,5 & 0,151 \\
\hline $\begin{array}{l}\text { Lama } \\
\text { Perawatan di RS } \\
\text { (hari) }\end{array}$ & $>1$ hari & 1 & 1,56 & 1 & 1,56 & \\
\hline $\begin{array}{l}\text { Outcome Klinis: } \\
\text { Perbaikan gejala }\end{array}$ & $\begin{array}{l}\text { Gejala } \\
\text { hilang }\end{array}$ & 22 & 34,37 & 40 & 62,5 & 0,410 \\
\hline asma & $\begin{array}{l}\text { Gejala } \\
\text { berkurang }\end{array}$ & 1 & 1,56 & 1 & 1,56 & \\
\hline \multirow[t]{4}{*}{ Pekerjaan } & Pelajar & 11 & 17,18 & 4 & 6,25 & 0,001 \\
\hline & $\begin{array}{l}\text { Pegawai } \\
\text { Negeri } \\
\text { Sipil }\end{array}$ & 1 & 1,56 & 3 & 4,68 & \\
\hline & Swasta & 8 & 12,5 & 22 & 34,37 & \\
\hline & $\begin{array}{l}\text { Ibu rumah } \\
\text { tangga }\end{array}$ & 3 & 4,60 & 12 & 18,75 & \\
\hline
\end{tabular}

(Kelompok A: kombinasi salbutamol dan ipratropium bromide, Kelompok B: salbutamol tunggal Nilai $\mathrm{P}>0,05$ artinya data antara kelompok $\mathrm{A}$ dan $\mathrm{B}$ tidak ada perbedaan bermakna)

Tabel II. Terapi Serangan Asma di Rumah Sakit

\begin{tabular}{lcccc}
\hline $\begin{array}{c}\text { Terapi Serangan } \\
\text { Asma }\end{array}$ & \multicolumn{2}{c}{$\begin{array}{c}\text { Kelompok A } \\
\text { (n: 23) }\end{array}$} & \multicolumn{2}{c}{$\begin{array}{c}\text { Kelompok B } \\
\text { (n: 41) }\end{array}$} \\
\cline { 2 - 5 } & Frekuensi & Prosentase*(\%) & Frekuensi & Prosentase*(\%) \\
\hline Oksigen & 6 & 26,09 & 14 & 34,14 \\
Bronchodilator & 23 & 100,00 & 41 & 100,00 \\
antitusif ekspektoran & 6 & 26,09 & 2 & 4,88 \\
Kortikosteroid & 14 & 60,87 & 41 & 100,00 \\
\hline
\end{tabular}

(Kelompok A: kombinasi Salbutamol dan ipratropium bromide, Kelompok B: Salbutamol tunggal *)prosentase dari total Subjek per kelompok)

Tabel III. Data Biaya Medis Langsung

\begin{tabular}{cccc}
\hline Perincian Biaya (Rp.) & Kelompok A & Kelompok B & Uji Perbedaan \\
& $(n: 23)$ & $(n:$ 41) & Nilai P \\
\hline
\end{tabular}


Jurnal Insan Farmasi Indonesia, 3(1) Mei 2020 (38-49)

Amelia Lorensia

p-ISSN 2621-3184 ; e-ISSN 2621-4032

\begin{tabular}{|c|c|c|c|}
\hline Obat & 25.747 & 28.789 & 0,423 \\
\hline Alat Kesehatan & 75.618 & 75.618 & 1,000 \\
\hline Tenaga Kesehatan & 105.000 & 105.000 & 1,000 \\
\hline Biaya Kamar/ Fasilitas Penunjang & 45.000 & 45.000 & 1,000 \\
\hline Total Biaya & 251.365 & 254.407 & 0,816 \\
\hline
\end{tabular}

(Kelompok A: kombinasi Salbutamol dan ipratropium bromide, Kelompok B: Salbutamol tunggal Nilai $\mathrm{P}>0,05$ artinya data antara kelompok $\mathrm{A}$ dan B tidak ada perbedaan bermakna)

Tabel IV. Data Outcome Klinis

\begin{tabular}{lccrr}
\hline Outcome & \multicolumn{2}{c}{$\begin{array}{c}\text { Kelompok A } \\
(\mathbf{n : ~ 2 3 )}\end{array}$} & $\begin{array}{c}\text { Kelompok B } \\
\text { (n: 41) }\end{array}$ & \multicolumn{2}{c}{$\begin{array}{c}\text { Uji Perbedaan } \\
\text { Nilai P }\end{array}$} \\
\hline $\begin{array}{l}\text { Lama pengobatan } \\
\text { rumah sakit (menit) }\end{array}$ & 67,78 & 83,65 & 0,386 \\
$\begin{array}{l}\text { Perbaikan hilangnya } \\
\text { gejala asma (\%) }\end{array}$ & 95,0 & 97,5 & 0,676 \\
\hline
\end{tabular}

(Kelompok A: kombinasi Salbutamol dan ipratropium bromide, Kelompok B: Salbutamol tunggal Nilai $\mathrm{P}>0,05$ artinya data antara kelompok A dan B tidak ada perbedaan bermakna)

Hal ini tidak sesuai dengan tarif INA-CBGs. Tarif INA-CBGs adalah tarif dengan sistem paket yang dibayarkan per episode pelayanan kesehatan, yaitu suatu rangkaian perawatan pasien sampai selesai, besar kecil tarif tidak akan dipengaruhi oleh jumlah hari perawatan. Tarif INACBGs berdasarkan Permenkes nomor 52 tahun 2016, untuk rumah sakit regional 1 kelas B pemerintah untuk eksaserbasi asma tingkat keparahan ringan masuk pada kode J-4-18-I dengan deskripsi kode INA CBGs untuk perawatan asma dan bronkiolitis (ringan) mencapai Rp. 2.722.900,00 sementara eksaserbasi asma tingkat keparahan sedang masuk pada kode J4-18-II dengan deskripsi kode INA CBGs untuk perawatan asthma dan bronkiolitis (sedang) mencapai Rp. $3.632 .800,00^{20}$ Hal ini tidak sesuai dengan tarif INA CBGs kemungkinan disebabkan karena biaya medis langsung yang dihitung hanya eksaserbasi asma tanpa penyakit penyerta yang membuat pengobatan semakin kompleks, selain hanya eksaserbasi asma yang diperhitungkan tanpa bronkiolitis, dan biaya alat kesehatan, kamar, dokter, dan perawat di rawat inap disamakan biayanya di IGD dan tidak bertambah bila pasien rujuk rawat inap. Sehingga pembeda antara 2 kelompok adalah pengobatan dan lama rawat mulai IGD sampai di rawat inap hingga keluar Rumah Sakit.

Meskipun harga obat kombinasi nebulizer salbutamol dan ipratropium bromida Rp. 6.669,00 lebih mahal 
Jurnal Insan Farmasi Indonesia, 3(1) Mei 2020 (38-49)

Amelia Lorensia

p-ISSN 2621-3184 ; e-ISSN 2621-4032

dibanding harga nebulizer salbutamol tunggal Rp. 4.680,00 tetapi secara pengelompokan berbeda. kelompok B sebagai obat pembanding (nebulizer salbutamol), kebanyakan subjek mendapatkan oksigen. Berbeda dengan kelompok A sebagai obat uji (kombinasi nebulizer salbutamol dan ipratropium bromida), kebanyakan subjek tidak mendapat oksigen. Sehingga besar biaya kelompok A sebagai obat uji (kombinasi nebulizer salbutamol dan ipratropium bromida) Rp. 253.854,00 lebih kecil dari kelompok B sebagai obat pembanding (nebulizer salbutamol) yaitu $\mathrm{Rp}$. 257.386,00.

\section{Outcome Lama Pengobatan}

Secara teori mula kerja obat nebulizer salbutamol yaitu 5 menit setelah diguabenakan. Sementara ipratropium bromida mula kerja obat lebih lama sekitar 30-60 menit akan tetapi outcome lama pengobatan di IGD ini merupakan awal pasien masuk ke rumah sakit sampai jam keluar dari IGD rumah sakit sehingga kesulitan yang dihadapi adalah menentukan jam pemberian obatnya dikarenakan tidak terlampir dalam rekam medik akibatnya mula kerja obat sulit ditentukan secara pasti.

Penatalaksanaan eksaserbasi asma di IGD diberikan agonis B2 kerja singkat setiap 20 menit selama 1 jam, oksigen bila saturasi dibawah $90 \%$, dan kortikosteroid bila perlu. Setelah itu dilakukan pemeriksaan fisik, saturasi oksigen, dan pemeriksaan lainnya. Bila respon baik maka pasien boleh pulang. Bila responnya buruk, maka pasien di rujuk ke rawat inap ${ }^{2}$. kedua kelompok ini tidak sesuai dengan standar penatalaksanaan eksaserbasi asma di IGD karena ratarata outcome lama pengobatan di IGD untuk kelompok A yaitu, 67,78 menit sementara rata-rata outcome lama pengobatan di IGD kelompok B yaitu 83,65 menit.

\section{Outcome Gejala Sesak}

Outcome perbaikan gejala hanya diliat sesak, seharusnya diliat juga fungsi paru dari pasien seperti arus puncak ekspirasi dan volume ekspirasi paksa dalam 1 detik. Alasan diliatnya fungsi paru untuk mengetahui tingkat keparahan pasien dan sebagai penegakan adanya gangguan paru, 
Jurnal Insan Farmasi Indonesia, 3(1) Mei 2020 (38-49)

Amelia Lorensia

p-ISSN 2621-3184 ; e-ISSN 2621-4032

salah satu caranya menggunakan

spirometri $^{2}$.

Tabel V. Perhitungan ACER

\begin{tabular}{lcr}
\hline Perhitungan ACER dengan outcome: & $\begin{array}{c}\text { Kelompok A } \\
\text { (n: 23) }\end{array}$ & $\begin{array}{c}\text { Kelompok B } \\
\text { (n: 41) }\end{array}$ \\
\hline Lama pengobatan di rumah sakit (rupiah/menit) & $3.708,54$ & $3.041,32$ \\
Perbaikan hilangnya gejala asma (rupiah/\%) & $262.934,10$ & $260.930,25$ \\
\hline
\end{tabular}

(Kelompok A: kombinasi Salbutamol dan ipratropium bromide, Kelompok B: Salbutamol tunggal)

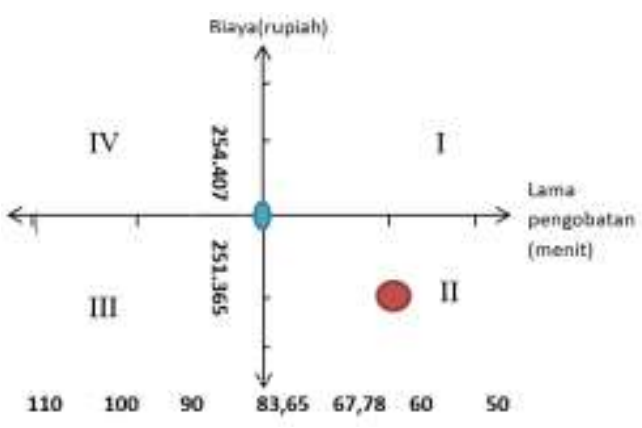

(a)

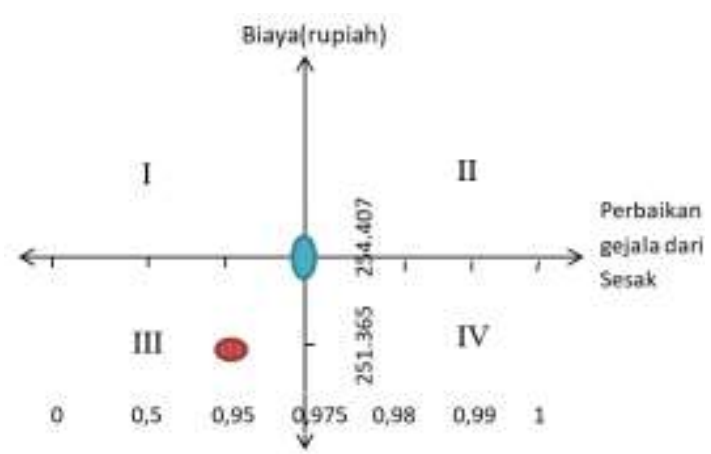

(b)

Keterangan : O Salbutamol tunggal

: kombinasi Salbutamol dan ipratropium bromida

I : Trade off yaitu obat uji lebih efektif dan lebih mahal dari obat pembanding

II :dominant yaitu obat uji lebih efektif dan lebih murah dari obat pembanding

III :Trade off yaitu obat uji lebih efektif dan lebih mahal dari obat pembanding

IV :dominated yaitu obat uji kurang efektif dan lebih mahal dari obat pembanding

Gambar I. (a) Cost-Effectiveness Plane Outcome Lama Pengobatan di IGD; (b) CostEffectiveness Plane Outcome Perbaikam Gejala Sesak

Berdasarkan nilai ACER (tabel

5), dari nilai ACER baik pada outcome lama perawatan dan perbaikan gejala

Hasil serupa juga dapat ditampilkan dalam cost-effectiveness plane berdasarkan outcome lama pengobatan di IGD menggambarkan dominant yaitu obat uji (kombinasi nebulizer salbutamol dan ipratropium bromida) lebih efektif dan lebih murah dari obat pembanding (nebulizer salbutamol) pada gambar 1a (kuadran menunjukkan kelompok B memiliki nilai ACER yang lebih kecil daripada kelompok A.

II). Sedangkan dalam costeffectiveness plane berdasarkan outcome penurunan gejala sesak menggambarkan trade-off yaitu obat uji (kombinasi nebulizer salbutamol dan ipratropium bromida) lebih efektif dan lebih murah dari obat pembanding (nebulizer salbutamol) pada gambar 1 b (kuadran IV). 
Jurnal Insan Farmasi Indonesia, 3(1) Mei 2020 (38-49)

Amelia Lorensia

p-ISSN 2621-3184 ; e-ISSN 2621-4032

Hasil Mann Whitney U lama pengobatan di IGD antara kelompok A (kombinasi aslbutamol dan ipratropium bromida) yaitu 121,52 menit dan B (salbutamol tunggal) yaitu 224,14 menit untuk pasien eksaserbasi asma di IGD tidak ada perbedaan signifikan karena nilai $\mathrm{P}<0,05$. Hal ini sesuai dengan penelitian yang dilakukan Kirkland et al. ${ }^{16}$ menyatakan secara keseluruhan, pasien yang menerima terapi kombinasi salbutamol dan antikholinergik secara inhalasi diperkirakan 65 pasien lebih sedikit per 1000 akan membutuhkan rawat inap setelah menerima terapi dibandingkan 231 per 1000 pasien yang menerima salbutamol saja. Meskipun terapi kombinasi salbutamol lebih efektif dari pada salbutamol saja dalam mengurangi rawat inap pada peserta dengan eksaserbasi berat, tapi tidak ditemukan pada peserta eksaserbasi ringansedang (uji untuk perbedaan antara subkelompok $\mathrm{P}=0,02$ ).

Hasil Mann Whitney U perbaikan gejala asma antara kelompok A (kombinasi aslbutamol dan ipratropium bromida) yaitu 0,95 artinya 1 orang masih terasa sesak dan kelompok B (salbutamol tunggal) yaitu 0,97 artinya 1 orang masih merasa sesak untuk pasien eksaserbasi asma di IGD tidak ada perbedaan signifikan karena nilai $\mathrm{P}>0,05$. Hal ini sesuai dengan penelitian Vexana et al. 21, yang menyatakan tidak ada perbedaan signifikan fungsi paru terhadap kelompok yang diberi kombinasi beta-agonist short acting dan antikholinergik dengan beta-2agonist tunggal pada eksaserbasi asma.

\section{Keterbatasan Penelitian}

Keterbatasan penelitian ini yaitu mengandalkan data sekunder yaitu rekam medis, rekam medis yang digunakan merupakan rekam medis non elektronik dimana tidak ada pencatatan lama pengobatan di IGD di rekam medis tetapi pencatatan waktunya ada di database dan tidak mempertimbangkan faktor stress, aktivitas fisik serta tingkat pendidikan masing-masing subjek.

\section{KESIMPULAN}

Kombinasi salbutamol dan ipratropium bromida lebih cost- 
Jurnal Insan Farmasi Indonesia, 3(1) Mei 2020 (38-49)

Amelia Lorensia

p-ISSN 2621-3184 ; e-ISSN 2621-4032

effective dari salbutamol tunggal

berdasarkan outcome lama perawatan

dirumah sakit. Sedangkan pada

outcome penurunan gejala,

menunjukkan posisi trade-off artinya

kombinasi salbutamol dan ipratropium

bromida lebih murah tetapi tidak lebih

\section{DAFTAR PUSTAKA}

1. Oemiati, R., Sihombing, M.Q. (2010). Faktor-Faktor yang Berhubungan dengan Penyakit Asma Di Indonesia, Media Litbang Kesehat., 20(1),pp.41-50.

2. Global Initiative for Asthma. (2019). Global Strategy for Asthma Management and Prevention (online), Available at: https://ginasthma.org/reports/201 9-gina-report-global-strategy-forasthma-management-and-

prevention/ [diakses 1 Maret 2019].

3. Travers, A.H., Jones, A.P., Camargo, C.A., Milan, S.J., Rowe, B.H. (2012). Addition of Intravenous beta 2 -agonists to inhaled beta (2)-agonists for acute asthma, Cochrane Database Syst Rev., CD010256.

4. Lorensia, A., Ikawati, Z., Andayani, T.M., Maranatha, D., Wahjudi, M. $\left(2016^{\mathrm{a}}\right)$. Comparison of electrolyte disturbance of using intravenous aminophylline versus nebulization salbutamol for exacerbation asthma in Surabaya, Indonesia, Int $J$ Pharm Clin Res, 8(4),pp.221-228.

5. Lorensia, A., Wahjuningsih, E., Supriadi. (2012). Safety of Aminophylline for Asthma efektif dari salbutamol tunggal. Selain itu, tidak ada perbedaan signifikan antara besar biaya pada pasien eksaserbasi asma, lama pengobatan, dan perbaikan gejala antara kombinasi salbutamol dan ipratropium bromide.

Therapy in Delta Surya Hospital at Sidoarjo, J Farm Klin Indones., 1(4),pp.154-161.

6. Lorensia, A., Ikawati, Z., Andayani, T.M., Maranatha, D. (2018). Perbandingan Perbaikan Nilai Peak Ekspiratory Flow Penggunaan Aminofilin dan Salbutamol pada Eksaserbasi Asma, Indones $J$ Chest, 5(2),pp.34-43.

7. Das, S., Bandyopadhyay, A., Bhattacharya, S., Biswas, I., Bairagya, T. (2011). A comparative study of efficacy and safety of arformoterol and salbutamol nebulization as rescue therapy in acute non-severe asthma, Indian $J$ Pharmacol., 43(4),pp.463.

8. Lorensia, A., Canggih, B., Wijaya, R.I. $\left(2013^{\mathrm{a}}\right)$. Analisis Adverse Drug Reactions pada Pasien Asma di Suatu Rumah Sakit, Surabay,. J Farm Indones., 6(3),pp.142-150.

9. Lugogo, N.L., Maclntyre, N.R. (2008). Life-Threatening Asthma: Pathophysiology and Management, Respi Care, 53(6),pp.726-735.

10. Lorensia, A., Wijaya, R.I., Canggih, B. $\left(2013^{\mathrm{b}}\right)$. Studi 
Jurnal Insan Farmasi Indonesia, 3(1) Mei 2020 (38-49)

Amelia Lorensia

p-ISSN 2621-3184 ; e-ISSN 2621-4032

Efektifitas Biaya Terkait

Pemilihan Obat Asma Bronkiale

Rawat Inap di Suatu Rumah Sakit

Swasta di Surabaya, J Ilm Sains

Teknol., 7(1),pp.56-63.

11. Domínguez-Ortega, J., Phillips-

Anglés, E., Barranco, P., Quirce,

S. (2015). Cost-effectiveness of asthma therapy: a comprehensive review, J Asthma, 52(6),pp.529537.

12. Lorensia, A., Wijaya, R.I. $\left(2016^{\mathrm{b}}\right)$. Hubungan Jumlah Obat Yang Digunakan Terhadap Risiko Terjadinya Drug-Related Problems Pada Pasien Asma Di Suatu Rumah Sakit Di Surabaya, J Trop Pharm Chem., 3(4),pp.232-238.

13. Lorensia, A. (2018). Buku Ajar Farmakoekonomi: Menghadapi Tingginya Lonjakan Biaya Pengobatan Yang Mengancam Kestabilan Perekonomian. Surabaya: CV M-Brother.

14. Lorensia, A., Amalia, R.A. (2015) Studi Farmakovigilans pengobatan Asma pada Pasien Rawat Inap di Suatu Rumah Sakit Di Bojonegoro, J Ilm Manuntung, 1(1),pp.8-18.

15. Mafruhah, O.R., Syaputra, B., Sari CP. (2016). Evaluasi Efektivitas Terapi pada Pasien Asma di Rumah Sakit Khusus Paru Respira Yogyakarta Kalasan Periode November 2014Januari 2015, Jurnal Ilmiah Farmasi, 12(2),pp.66-72.

16. Kirkland, S.W., Vandenberghe, C., Voaklander, B., Nikel, T., Campbell, S., Rowe, B.H. (2017). Combined inhaled beta-agonist and anticholinergic agents for emergency management in adults with asthma, Cochrane Database Syst Rev., 1, CD001284.

17. Cunnamaa, L., Sinanovic, E., Rammaa, L., Fostera, N., Berrie, L., Stevens, W., Molapo, S., Marokane, P., Mccarthy, K., Churchyard, G., Avassall, A. (2016). Using Top-Down and Bottom-Up Costing Approaches In LMICs: The Case for Using Both to Assess The Incremental Costs of New Technologies at Scale, Health Econ., 25(Suppl. 1),pp.53-66.

18. Olsson, T.M. (2011). Comparing top-down and bottom-up costing approaches for economic evaluation within social welfare, Eur J Heal Econ., 12(5),pp.445453.

19. Meslin, E.M. (2010). The value of using top-down and bottom-up approaches for building trust and transparency in biobanking,. Public Health Genomics, 13(4),pp.207-214.

20. Indonesian Case Based Groups (INA-CBG's) dan non Indonesian Case Based. (2016). Peraturan Menteri Kesehatan Republik Indonesia Nomor 52 Tahun 2016 Tentang Standar Tarif Pelayanan Kesehat Dalam Penyelenggaraan Progr Jaminan Kesehat.

21. Vézina, K., Chauhan, B.F., Ducharme, F.M. (2014). Inhaled anticholinergics and short-acting beta 2-gonists versus short-acting beta2-agonists alone for children with acute asthma in hospital, Cochrane Database Syst Rev., CD010283. 


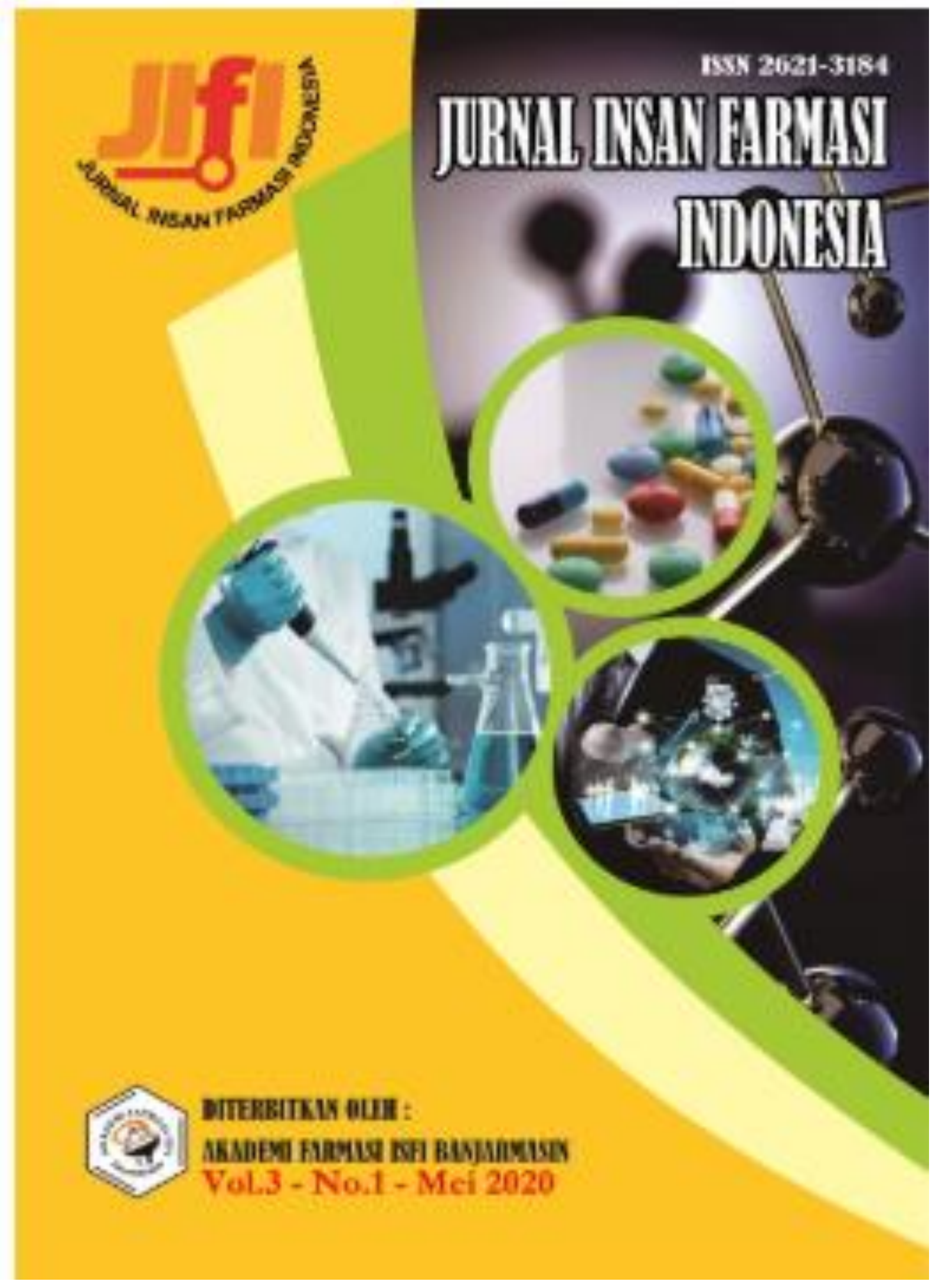




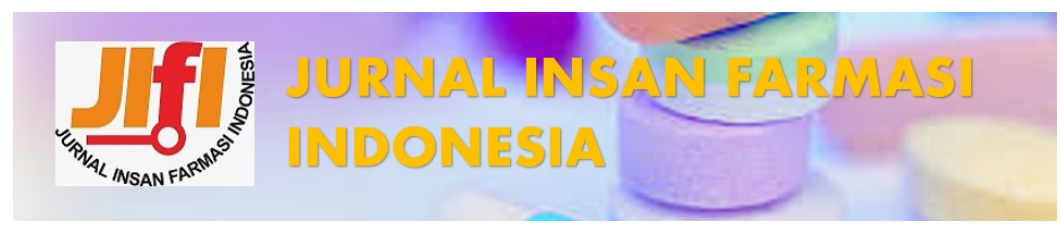

Current Archives Announcements About

Search

Home / Editorial Team

\section{REVIEWER}

Prof. Dr. Abdul Rohman, M.Si., Apt. (Universitas Gadjah Mada, Indonesia)

Prof. Muchtaridi, M.Si.,Ph.D, Apt (Universitas Padjajaran, Indonesia)

Prof. Dr. Gemini Alam, M.Si., Apt. (Universitas Hasanuddin, Indonesia)

Dr. AP. Moch Fadli Asmani (Management and Science University, Malaysia)

drh. Sitarina Widyarini, MP., Ph.D (Universitas Gadjah Mada, Indonesia)

Peni Indrayudha, M.Biotech., Ph.D., Apt (Universitas Muhammadiyah Surakarta, Indonesia)

Erindyah Retno Wikantyasning, M.Si., Ph.D., Apt (Universitas Muhammadiyah Surakarta, Indonesia)

Moch Saiful Bachri, M.Si. Ph.D., Apt (Universitas Ahmad Dahlan, Indonesia)

Dr. Farida Hayati, MSi., Apt. (Universitas Islam Indonesia, Indonesia)

Dr. Laela Hayu Nurani, M.Si., Apt (Universitas Ahmad Dahlan, Indonesia)

Dr. Rahmat Gunawan, M.Si (Universitas Mulawarman, Indonesia)

\section{EDITOR}

Ikhdya Khairani (Akademi Farmasi ISFI Banjarmasin, Indonesia)

Akhmad Baihaqi (Akademi Farmasi ISFI Banjarmasin, Indonesia) 
Muhammad Amin (Akademi Farmasi ISFI Banjarmasin, Indonesia)

Normilawati (Akademi Farmasi ISFI Banjarmasin, Indonesia)

Suryo Supraptono (Akademi Farmasi ISFI Banjarmasin, Indonesia)

wahyudi (Akademi Farmasi ISFI Banjarmasin, Indonesia)

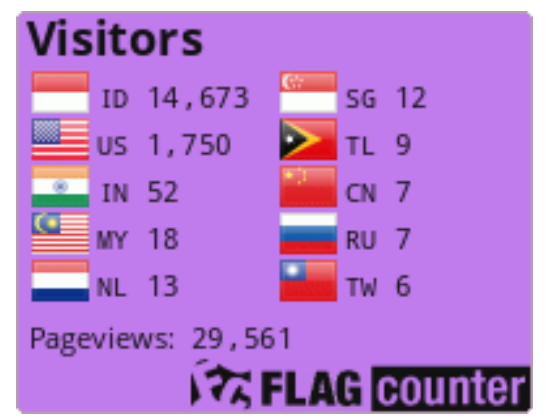

TOOLS by
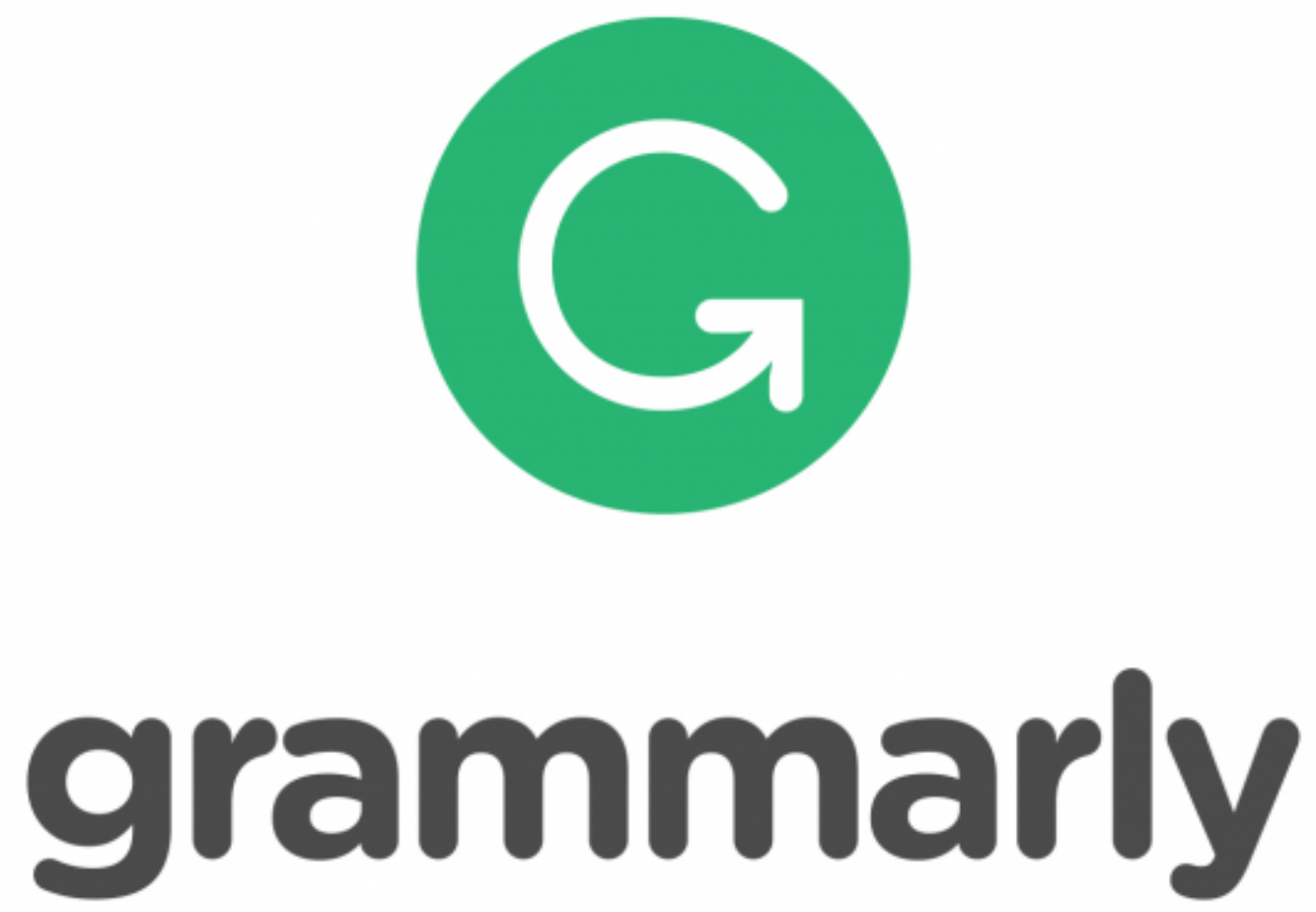

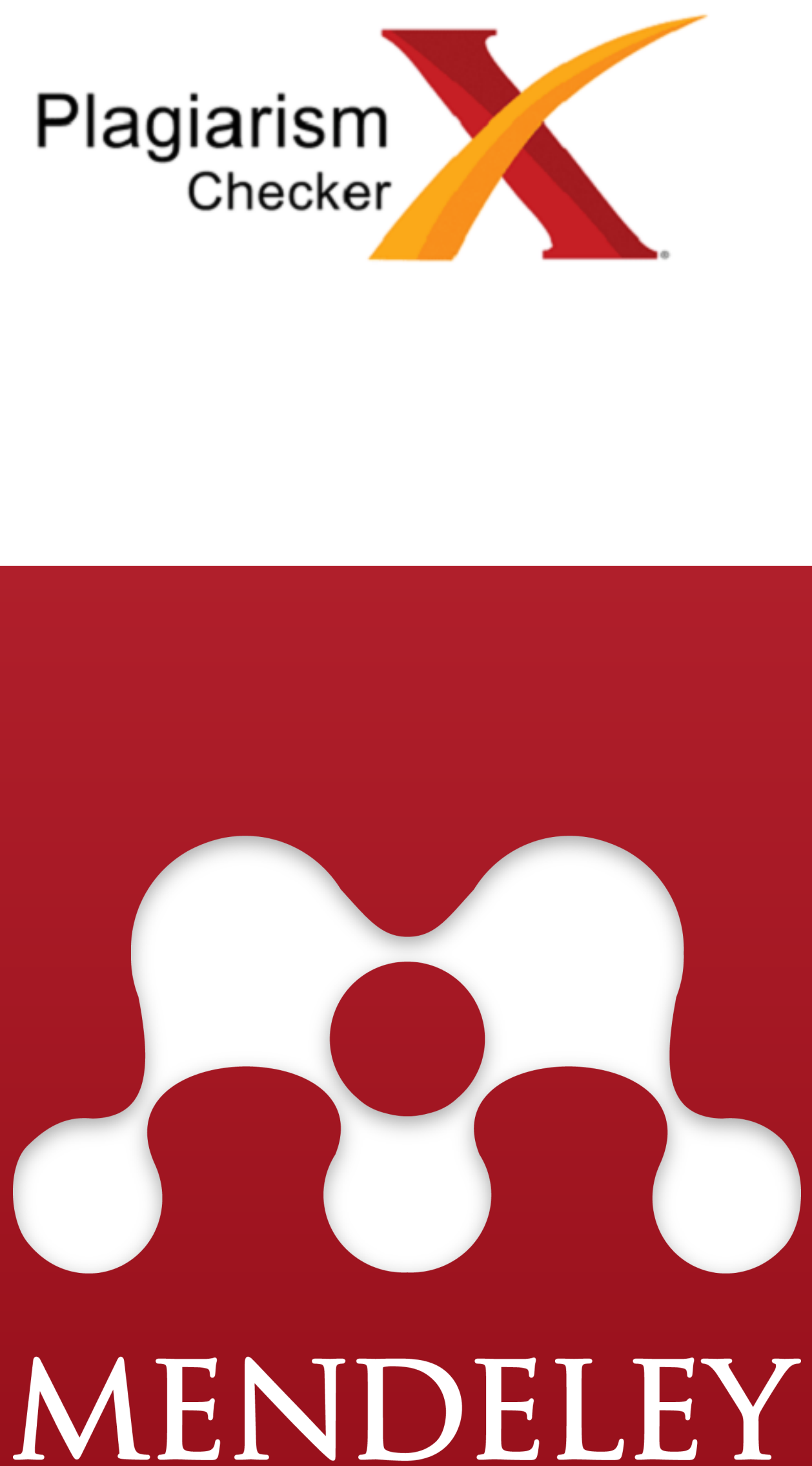

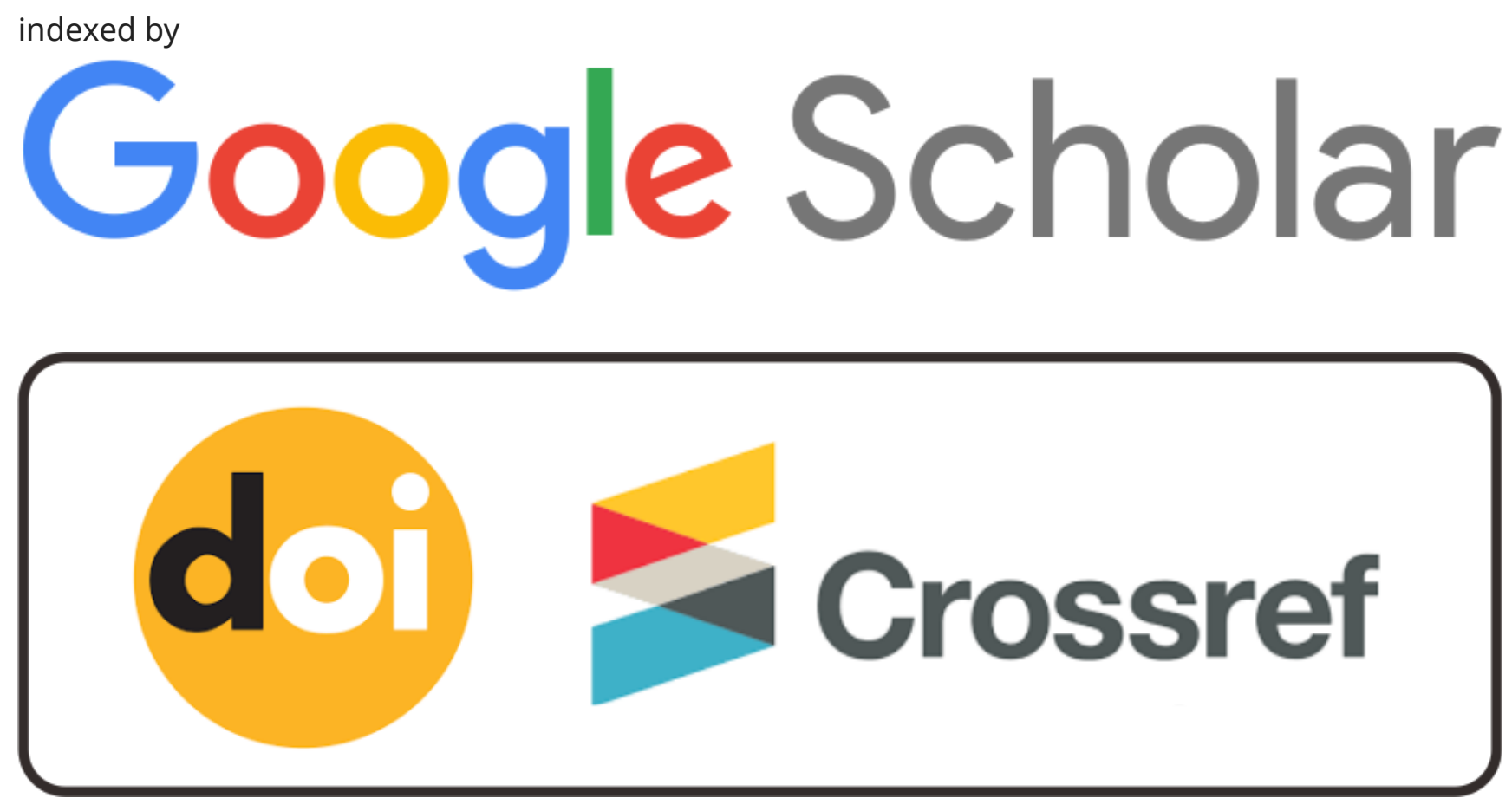

template JIFI

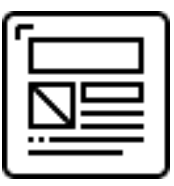

Make a Submission

Open Journal Systems

\section{Information}

For Readers

For Authors

For Librarians 


\section{Redaksi Jurnal Insan Farmasi Indonesia}

Akademi Farmasi ISFI Banjarmasin

Jl. Flamboyan III/7b Kayu Tangi 70123

Banjarmasin Kalimantan Selatan

Telepon: (0511)-3301610, 3300221

Email: jiis@akfar-isfibjm.ac.id

\section{Platform \& workflow by OJS / PKP}




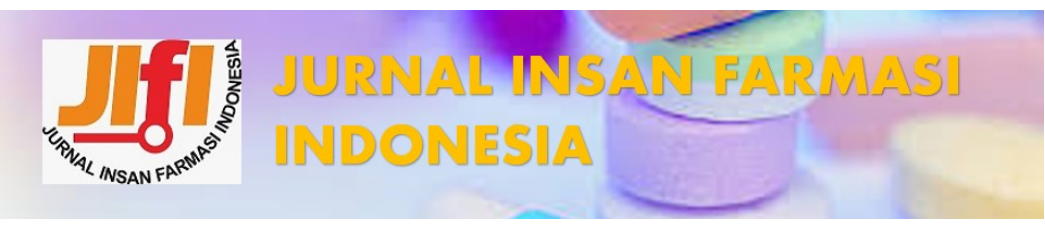

Current Archives Announcements About

Search

Home / Archives / Vol 3 No 1 (2020): Jurnal Insan Farmasi Indonesia

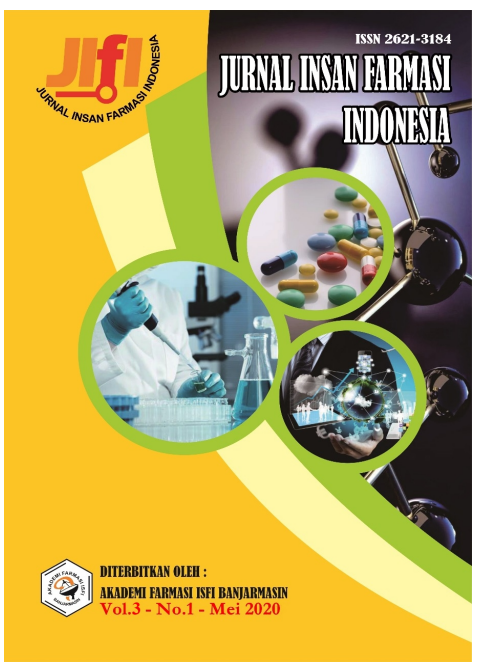

DOI: https://doi.org/10.36387/jifi.v3i1

Published: 2020-05-30

\section{Articles}

ANALISIS EFEKTIVITAS PENGGUNAAN ANTIBIOTIKA PADA PASIEN SIROSIS HEPATIS DENGAN KOMPLIKASI SPONTANEOUS BACTERIAL PERITONITIS DI SALAH SATU RUMAH SAKIT DI YOGYAKARTA

Adnan Adnan, Lolita Lolita

$1-8$

$\triangle$ PDF (Bahasa Indonesia)

EFEK GEL EKSTRAK ETANOL DAUN ASAM JAWA (Tamarindus indica L.) SEBAGAI PENYEMBUHAN LUKA INSISI PADA TIKUS JANTAN GALUR Sprague Dawley

Agustina Susilowati, Nanda Syta Nur'aini

$9-18$ 
ه PDF (Bahasa Indonesia)

ANALISIS BIAYA KEMOTERAPI PASIEN KANKER PAYUDARA DAN KANKER SERVIKS DI RSUD ULIN BANJARMASIN

Noor Aisyah, Akhmad Syarifuddin, Putri Amami, Mardiana Mardiana $19-28$

因 PDF (Bahasa Indonesia)

GAMBARAN TINGKAT PENGETAHUAN DAN KEPATUHAN IBU HAMIL TENTANG KONSUMSI Tablet Fe DENGAN APLIKASI POIN OTDA DI PUSKESMAS ALALAK SELATAN

Amaliyah Wahyuni, Ahmad Maki Zamzami

$29-37$

因 PDF (Bahasa Indonesia)

\section{ANALISIS EFEKTIFITAS-BIAYA ANTARA KOMBINASI SALBUTAMOL-IPRATROPIUM DENGAN SALBUTAMOL PADA SERANGAN ASMA}

Amelia Lorensia, Ferdias Kurnia Bahari

$38-49$

因 PDF (Bahasa Indonesia)

BIAYA PENGGUNAAN OBAT HIPOGLIKEMIK ORAL (OHO) METFORMIN DAN GLIMEPIRID PADA PASIEN DIABETES MELITUS TIPE II RAWAT JALAN NON BPJS DI SERANG TAHUN 2018 TIDAK BERBEDA SIGNIFIKAN

Aprilla Ayu Wulandari, Rika Revina, Dhigna Luthfiyani Citra Pradana

$50-55$

因 PDF (Bahasa Indonesia)

REVIEW ARTIKEL : POTENSI LIKOPEN DARI BUAH TOMAT (Solanum lycopersicum L) SEBAGAI ANTIAGING TOPIKAL

Dani Sujana, Diah Wardani, Nurul Nurul

$56-65$

因 PDF (Bahasa Indonesia)

UJI POTENSI MINYAK ATSIRI DAUN JERUK PURUT (Citrus Hystrix D.C) SEBAGAI ANTIOKSIDAN DAN ANTIBAKTERI

Dwi Rizki Febrianti, Novia Ariani

66-74

因 PDF (Bahasa Indonesia) 
UJI AKTIVITAS ANTIBAKTERI EKSTRAK DAUN BAWANG DAYAK (Eleutherine palmifolia Merr.) TERHADAP Escherichia coli

Eka Kumalasari, Dhea Agustina, Novia Ariani

$75-84$

PDF (Bahasa Indonesia)

PENGARUH PEMBERIAN EKSTRAK ETANOL RUMPUT LAUT MERAH (Gracilaria verrucosa) TERHADAP WAKTU PENDARAHAN (BLEEDING TIME) PADA TIKUS PUTIH JANTAN GALUR WISTAR Keni Idacahyati, Dimas Rahman Fauzi, Tresna Lestari $85-93$

PDF (Bahasa Indonesia)

TINGKAT PENGETAHUAN PENGGUNA KONTRASEPSI KB HORMONAL TERHADAP EFEK SAMPING PENINGKATAN TEKANAN DARAH DI APOTEK PERINTIS BANJARMASIN

Mochammad Maulidie Alfiannor Saputera, Devia Pratiwi, Anna Khumaira Sari, Noverda Ayuchecaria, Nazhipah Isnani

$94-103$

PDF (Bahasa Indonesia)

KEPATUHAN PENGGUNAAN OBAT PADA PASIEN HIPERTENSI DI INSTALASI RAWAT JALAN SALAH SATU RSUD DI WILAYAH DAERAH ISTIMEWA YOGYAKARTA

Muhammad Muhlis, Alissa Jihan Prameswari

$104-113$

㘣 PDF (Bahasa Indonesia)

AKTIVITAS ANTIOKSIDAN SEDUHAN DAUN KOPI KAWA KERING (Coffea arabica L) DENGAN METODE DPPH

Musyirna Rahmah Nasution, Martina Br Manullang

$114-123$

$\triangle$ PDF (Bahasa Indonesia)

UJI AKTIVITAS ANTIBAKTERI GEL EKSTRAK ETANOL DAUN ANGSANA (Pterocarpus indicus Willd.) TERHADAP BAKTERI Staphylococcus aureus

Nelly Suryani Djamain, Vivi Anggia, Nia Fachrunisa

$124-131$

PDF (Bahasa Indonesia)

PENETAPAN KADAR FENOLIK TOTAL EKSTRAK BATANG BAJAKAH TAMPALA (Spatholobus littoralis Hassk.) MENGGUNAKAN SPEKTROFOTOMETRI UV-VISIBLE

Noverda Ayuchecaria, Mochammad Maulidie Alfiannor Saputera, Rakhmadhan Niah

$132-141$ 
因 PDF (Bahasa Indonesia)

TINGKAT PENGETAHUAN PASIEN GLAUKOMA TENTANG CARA PENGGUNAAN DAN PENYIMPANAN OBAT TETES MATA TIMOLOL DI POLI MATA RSUD ULIN BANJARMASIN

Saftia Aryzki, Noverda Ayuchecaria

$142-153$

㘣 PDF (Bahasa Indonesia)

HUBUNGANPEMBERIAN IMUNISASI BACILLE CALMETTE GUERIN (BCG) TERHADAP FAKTOR KEJADIAN TUBERCULOSIS (TB) PARU BALITA DI KLINIK DEGRITHA BANJARBARU

Sari Wahyunita, Eny Hastuti, Arif Fauzi

$154-161$

S PDF (Bahasa Indonesia)

AKTIVITAS BIOLARVASIDA EKSTRAK DAUN JERUK NIPIS (Citrus aurantifolia) TERHADAP LARVA NYAMUK Culex sp

Siska Musiam, Agus Ariyanto, Noverda Ayuchecaria

$162-168$

因 PDF (Bahasa Indonesia)

EVALUASI FORMULASI TABIR SURYA ALAMI SEDIAAN GEL LIDAH BUAYA (Aloe vera) DAN RUMPUT LAUT MERAH (Eucheuma cottonii)

Srie Rezeki Nur Endah, Eddy Suhardiana

$169-176$

因 PDF (Bahasa Indonesia)

KEPATUHAN MINUM OBAT PASIEN HIPERTENSI DI PUSKESMAS KECAMATAN KEBON JERUK JAKARTA BARAT TAHUN 2019

Yardi Saibi, Yoga Sutrisno, Hendri Aldrat, Vidia Arlaini Anwar

$177-186$

因 PDF (Bahasa Indonesia)

PILOT TESTING KUESIONER KDQOL-SFTM PADA PASIEN GAGAL GINJAL TERMINAL DI RS PKU MUHAMMADIYAH BANTUL

Woro Supadmi, Yuni Lestari

$187-198$

因 PDF (Bahasa Indonesia) 


\section{Visitors

\begin{tabular}{|c|c|c|}
\hline - & ID 14,673 & 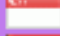 \\
\hline$\underline{\underline{\underline{2}}}$ & US 1,750 & $>$ \\
\hline 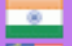 & IN 52 & \\
\hline (c) & WY 18 & \\
\hline & NL 13 & \\
\hline
\end{tabular} \\ Pageviews: 29,561 \\ i 7 FLAG counter}

\section{TOOLS by}
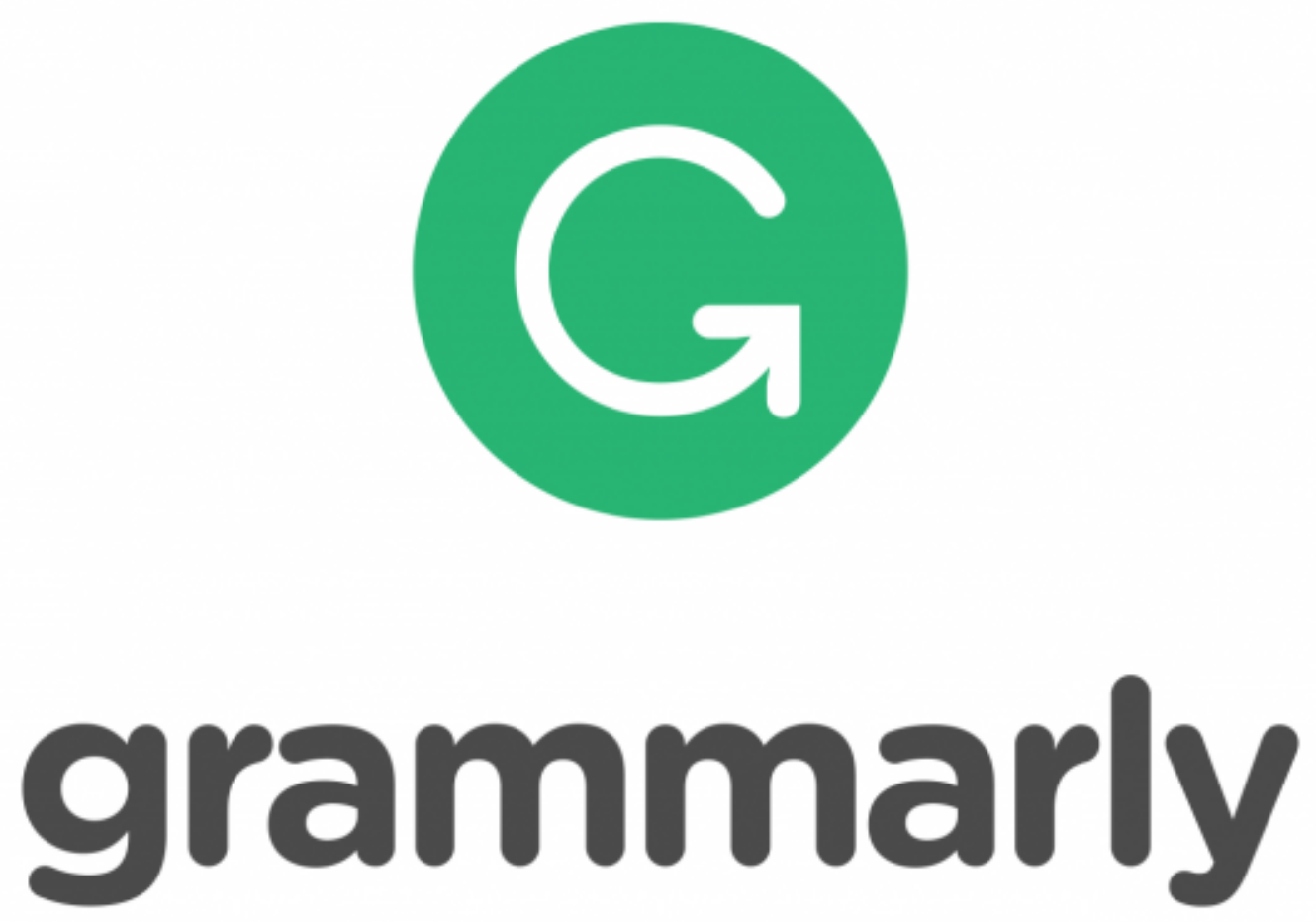

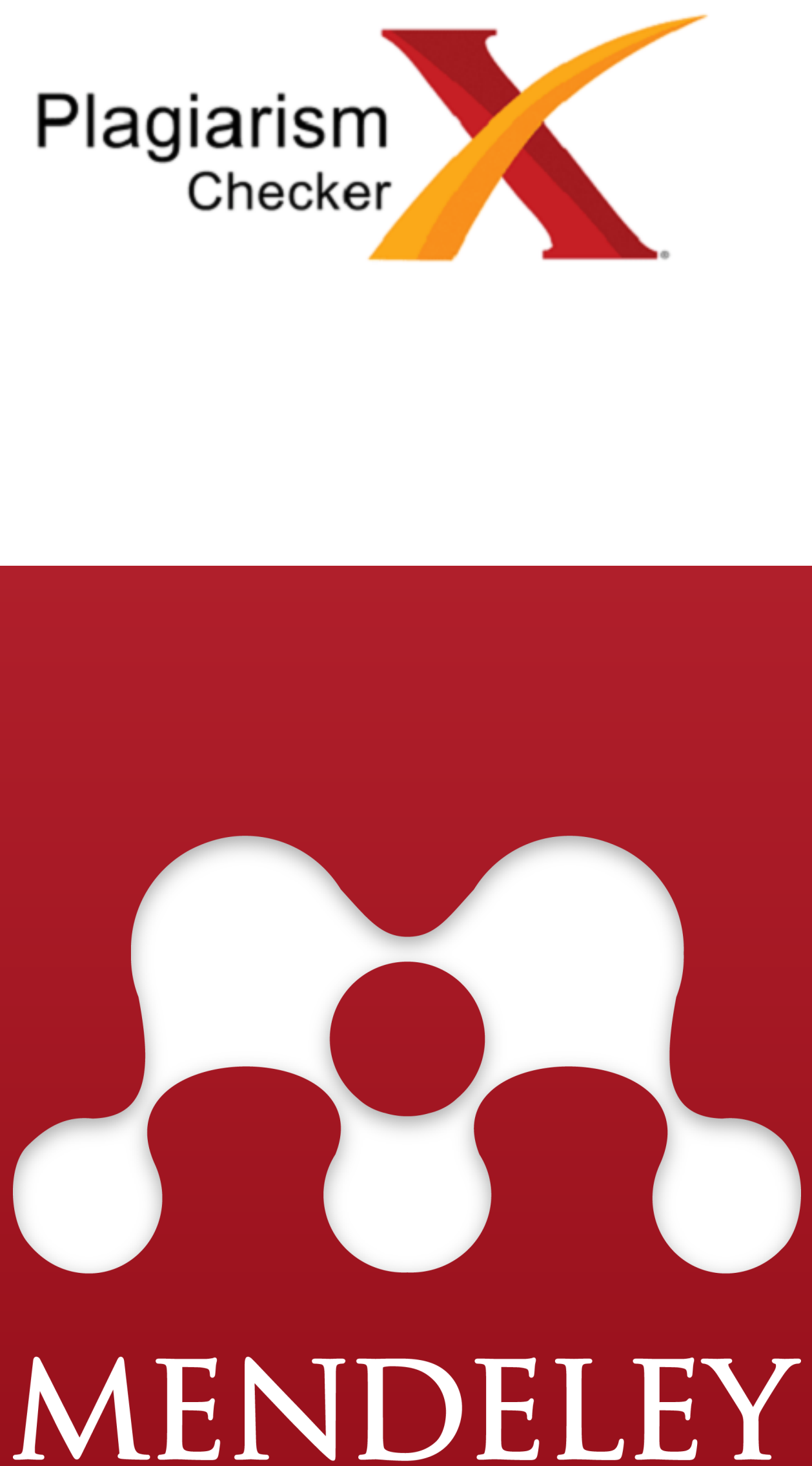

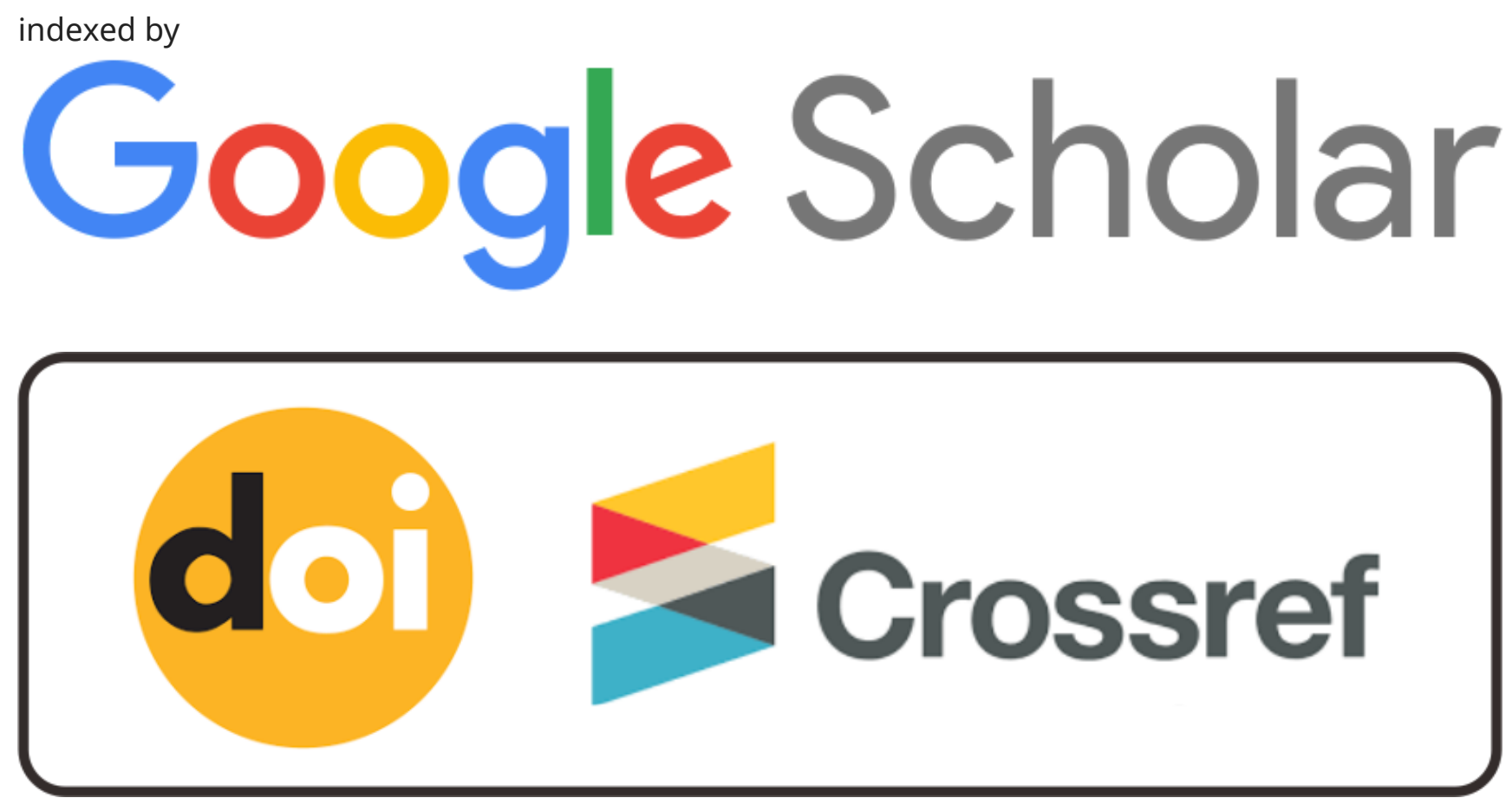

template JIFI

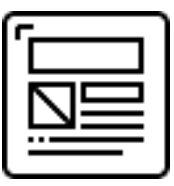

Make a Submission

Open Journal Systems

\section{Information}

For Readers

For Authors

For Librarians 


\section{Redaksi Jurnal Insan Farmasi Indonesia}

Akademi Farmasi ISFI Banjarmasin

Jl. Flamboyan III/7b Kayu Tangi 70123

Banjarmasin Kalimantan Selatan

Telepon: (0511)-3301610, 3300221

Email: jiis@akfar-isfibjm.ac.id

\section{Platform \& workflow by OJS / PKP}




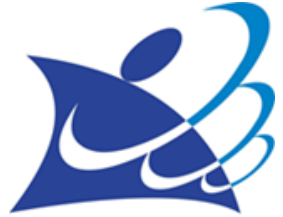

RISTEK-BRIN

KEMENTERIAN RISET DAN TEKNOLOGI/BADAN RISET

DAN INOVASI NASIONAL

DEPUTI BIDANG PENGUATAN RISET DAN PENGEMBANGAN

Gedung B.J.Habibie Lantai 19 - 20, Jalan M.H. Thamrin No. 8, Jakarta 10340

Telepon 021-3162222 Ext. 9702, 9782, 9707; Faksimile 021-3101728

Nomor $\quad:$ B/804/E5/E5.2.1/2019

Jakarta, 3 April 2020

Lampiran $\quad: 1$ (satu) Berkas

Perihal : Pemberitahuan Hasil Akreditasi Jurnal Ilmiah

Periode I Tahun 2020

Kepada Yth.

1. Pimpinan Perguruan Tinggi

2. Koordinator LL Dikti I s.d. XIV

3. Ketua Himpunan Profesi

4. Pengelola Jurnal Ilmiah

di seluruh Indonesia

Dengan hormat,

Sehubungan dengan hasil Akreditasi Jurnal Ilmiah Periode I Tahun 2020 dan telah diterbitkannya Surat Keputusan Menteri Riset dan Teknologi/Badan Riset dan Inovasi Nasional Nomor 85/M/KPT/2020, tanggal 01 April 2020, dengan hormat bersama ini kami sampaikan hasil akreditasi sebagaimana terlampir. Adapun ketentuan penerbitan sertifikat akreditasi sebagai berikut:

1. Bagi usulan akreditasi baru maka sertifikat akreditasi akan diterbitkan dan diberikan kepada pengelola jurnal.

2. Bagi usulan akreditasi ulang yang hasil akreditasi naik peringkat maka sertifikat akreditasi akan diterbitkan dan diberikan kepada pengelola jurnal.

3. Bagi usulan akreditasi ulang yang hasil akreditasi peringkatnya tetap dan telah memiliki sertifikat yang masih berlaku masa akreditasi, maka sertifikat baru tidak akan diterbitkan, dan sertifikat sebelumnya dapat digunakan sampai berakhir masa berlaku.

4. Bagi pengelola yang sudah terakreditasi dan namanya tercantum dalam SK sebelumnya serta belum memiliki sertifikat dapat meminta sertifikat terdahulu.

5. Penerbitan sertifikat dilakukan secara bertahap paling cepat 2 minggu setelah pengumuman ini dan dilakukan pemutakhiran data di laman : http://sinta2.ristekbrin.go.id/journals, penyerahan sertifikat dilakukan secara bertahap dapat diunduh langsung melalui akun pengusul di laman: http://arjuna.ristekbrin.go.id/ mulai tanggal 6 Juni 2020.

6. Bagi usulan yang ditolak administrasi dan usulan baru bisa mengajukan kembali melalui http://arjuna.ristekbrin.go.id/.

Atas perhatian dan kerja sama yang baik, kami ucapkan terima kasih.

Direktur Pengelolaan Kekayaan Intelektual

ttd

Heri Hermansyah

NIP. 197601181999031002

Tembusan :

Plt. Deputi Bidang Penguatan Riset dan Pengembangan 


\title{
MENTERI RISET DAN TEKNOLOGI/ KEPALA BADAN RISET DAN INOVASI NASIONAL REPUBLIK INDONESIA
}

\author{
KEPUTUSAN MENTERI RISET DAN TEKNOLOGI/ \\ KEPALA BADAN RISET DAN INOVASI NASIONAL \\ REPUBLIK INDONESIA
}

NOMOR 85/M/KPT/2020

TENTANG

PERINGKAT AKREDITASI JURNAL ILMIAH PERIODE I

TAHUN 2020

MENTERI RISET DAN TEKNOLOGI/

KEPALA BADAN RISET DAN INOVASI NASIONAL

REPUBLIK INDONESIA,

Menimbang : a. bahwa dalam rangka pembinaan dalam penyelenggaraan ilmu pengetahuan dan teknologi serta untuk meningkatkan relevansi, kuantitas, dan kualitas publikasi ilmiah ilmuwan Indonesia untuk mendukung daya saing bangsa diperlukan peringkat akreditasi jurnal ilmiah;

b. bahwa berdasarkan hasil akreditasi jurnal ilmiah yang ditetapkan oleh Tim Akreditasi Jurnal Ilmiah Kementerian Riset dan Teknologi/Badan Riset dan Inovasi Nasional pada tanggal 26 Maret 2020, telah diperoleh Peringkat Akreditasi Jurnal Ilmiah Periode I Tahun 2020;

c. bahwa berdasarkan pertimbangan sebagaimana dimaksud dalam huruf a dan huruf $b$, perlu menetapkan Keputusan Menteri Riset dan Teknologi/Kepala Badan Riset dan Inovasi Nasional tentang Peringkat Akreditasi Jurnal Ilmiah Periode I Tahun 2020;

Mengingat $: 1$. Undang-Undang Nomor 12 Tahun 2012 tentang Pendidikan Tinggi (Lembaran Negara Republik Indonesia Tahun 2012 Nomor 158, tambahan Lembaran Negara Republik Indonesia Nomor 5336); 
2. Undang-Undang Nomor 11 Tahun 2019 tentang Sistem Nasional Ilmu Pengetahuan dan Teknologi (Lembaran Negara Republik Indonesia Tahun 2019 Nomor 148, Tambahan Lembaran Negara Republik Indonesia, Tambahan Lembaran Negara Republik Indonesia Nomor 6374);

3. Peraturan Pemerintah Nomor 4 Tahun 2014 tentang Penyelenggaraan Pendidikan dan Pengelolaan Perguruan Tinggi (Lembaran Negara Republik Indonesia Tahun 2014 Nomor 16, Tambahan Lembaran Negara Republik Indonesia Nomor 5500);

4. Peraturan Presiden Nomor 50 Tahun 2020 tentang Kementerian Riset dan Teknologi (Lembaran Negara Republik Indonesia Tahun 2020 Nomor 89);

5. Keputusan Presiden Nomor 113/P Tahun 2019 tentang Pembentukan Kementerian Negara dan Pengangkatan Menteri Negara Kabinet Indonesia Maju Periode Tahun 20192024;

\section{MEMUTUSKAN:}

Menetapkan : KEPUTUSAN MENTERI RISET DAN TEKNOLOGI/KEPALA BADAN RISET DAN INOVASI NASIONAL TENTANG PERINGKAT AKREDITASI JURNAL ILMIAH PERIODE I TAHUN 2020.

KESATU : Menetapkan Peringkat Akreditasi Jurnal Ilmiah Periode I Tahun 2020 sebagaimana tercantum dalam Lampiran yang merupakan bagian yang tidak terpisahkan dari Keputusan Menteri/Kepala Badan ini.

KEDUA : Akreditasi Jurnal Ilmiah sebagaimana dimaksud dalam Diktum KESATU berlaku selama 5 (lima) tahun mulai dari nomor dan tahun sebagaimana tercantum dalam Lampiran yang merupakan bagian yang tidak terpisahkan dari Keputusan Menteri/Kepala Badan ini. 
KETIGA : Setiap jurnal ilmiah wajib mencantumkan masa berlaku akreditasi di dalam website jurnal dengan menuliskan tanggal penetapan dan tanggal akhir masa berlaku akreditasi.

KEEMPAT : Keputusan Menteri/Kepala Badan ini mulai berlaku pada tanggal ditetapkan.

Ditetapkan di Jakarta

pada tanggal 1 April 2020

MENTERI RISET DAN TEKNOLOGI/

KEPALA BADAN RISET DAN INOVASI

NASIONAL REPUBLIK INDONESIA,

ttd.

BAMBANG P.S. BRODJONEGORO

Salinan sesuai dengan aslinya KEMENTERIAN RISET DAN TEKNOLOGI/

BADAN RISET DAN INOVASI NASIONAL

Sekretariat Kementerian/Sekretariat Utama

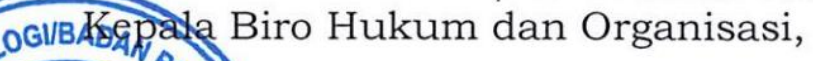


KEPUTUSAN MENTERI RISET DAN TEKNOLOGI/

KEPALA BADAN RISET DAN INOVASI NASIONAL REPUBLIK INDONESIA

NOMOR 85/M/KPT/2020

TENTANG

PERINGKAT AKREDITASI JURNAL ILMIAH

PERIODE I TAHUN 2020

PERINGKAT AKREDITASI JURNAL ILMIAH PERIODE 1 TAHUN 2020

\begin{tabular}{|c|c|c|c|c|c|}
\hline Peringkat & No. & Nama Jurnal & E-ISSN & Penerbit & Keterangan \\
\hline \multirow[t]{5}{*}{1} & $\overline{1}$ & $\begin{array}{l}\text { Bulletin of Chemical } \\
\text { Reaction } \\
\text { Engineering \& } \\
\text { Catalysis }\end{array}$ & 19782993 & $\begin{array}{l}\text { Departement of } \\
\text { Chemical } \\
\text { Engineering, } \\
\text { Diponegoro } \\
\text { University }\end{array}$ & $\begin{array}{l}\text { Reakreditasi } \\
\text { Tetap di } \\
\text { Peringkat } 1 \text { mulai } \\
\text { Volume } 15 \\
\text { Nomor } 1 \text { Tahun } \\
2020\end{array}$ \\
\hline & 2 & $\begin{array}{l}\text { Indonesian } \\
\text { Aquaculture Journal }\end{array}$ & 25026577 & $\begin{array}{l}\text { The Center for } \\
\text { Fisheries } \\
\text { Research, } \\
\text { Indonesian } \\
\text { Ministry of Marine } \\
\text { Affairs and } \\
\text { Fisheries }\end{array}$ & $\begin{array}{l}\text { Reakreditasi } \\
\text { Tetap di } \\
\text { Peringkat } 1 \text { mulai } \\
\text { Volume } 14 \\
\text { Nomor } 2 \text { Tahun } \\
2019\end{array}$ \\
\hline & 3 & $\begin{array}{l}\text { Indonesian Journal } \\
\text { of Chemistry }\end{array}$ & 24601578 & $\begin{array}{l}\text { Chemistry } \\
\text { Department, } \\
\text { Faculty of } \\
\text { Mathematics and } \\
\text { Natural Sciences, } \\
\text { Universitas } \\
\text { Gadjah Mada }\end{array}$ & $\begin{array}{l}\text { Reakreditasi } \\
\text { Tetap di } \\
\text { Peringkat } 1 \text { mulai } \\
\text { Volume } 20 \\
\text { Nomor } 1 \text { Tahun } \\
2020\end{array}$ \\
\hline & 4 & $\begin{array}{l}\text { Jurnal Ilmu Ternak } \\
\text { dan Veteriner }\end{array}$ & $2252696 X$ & $\begin{array}{l}\text { Indonesian } \\
\text { Center for Animal } \\
\text { Research and } \\
\text { Development }\end{array}$ & $\begin{array}{l}\text { Reakreditasi } \\
\text { Tetap di } \\
\text { Peringkat } 1 \text { mulai } \\
\text { Volume } 24 \\
\text { Nomor } 4 \text { Tahun } \\
2020 \\
\end{array}$ \\
\hline & 5 & $\begin{array}{l}\text { Kesmas: National } \\
\text { Public Health } \\
\text { Journal }\end{array}$ & 24600601 & $\begin{array}{l}\text { Fakultas } \\
\text { Kesehatan } \\
\text { Masyarakat } \\
\text { Universitas } \\
\text { Indonesia }\end{array}$ & $\begin{array}{l}\text { Reakreditasi } \\
\text { Tetap di } \\
\text { Peringkat } 1 \text { mulai } \\
\text { Volume } 14 \\
\text { Nomor } 2 \text { Tahun } \\
2019\end{array}$ \\
\hline
\end{tabular}

6. Molekul ... 


\begin{tabular}{|c|c|c|c|c|c|}
\hline \begin{tabular}{|l|} 
Peringkat \\
\end{tabular} & No. & Nama Jurnal & E-ISSN & Penerbit & Keterangan \\
\hline & 6 & $\begin{array}{l}\text { Molekul: Jurnal } \\
\text { Ilmiah Kimia }\end{array}$ & 25030310 & $\begin{array}{l}\text { Jurusan Kimia } \\
\text { FMIPA } \\
\text { Universitas } \\
\text { Jenderal } \\
\text { Soedirman }\end{array}$ & $\begin{array}{l}\text { Reakreditasi } \\
\text { Tetap di } \\
\text { Peringkat } 1 \text { mulai } \\
\text { Volume } 14 \\
\text { Nomor } 2 \text { Tahun } \\
2019\end{array}$ \\
\hline & 7 & $\begin{array}{l}\text { SAINS TANAH - } \\
\text { Journal of Soil } \\
\text { Science and } \\
\text { Agroclimatology }\end{array}$ & 23561424 & $\begin{array}{l}\text { Department of } \\
\text { Soil Science, } \\
\text { Faculty of } \\
\text { Agriculture, } \\
\text { Universitas } \\
\text { Sebelas Maret }\end{array}$ & $\begin{array}{l}\text { Reakreditasi } \\
\text { Tetap di } \\
\text { Peringkat } 1 \text { mulai } \\
\text { Volume } 15 \\
\text { Nomor } 1 \text { Tahun } \\
2018\end{array}$ \\
\hline \multirow[t]{5}{*}{2} & 1 & $\begin{array}{l}\text { Advances in Food } \\
\text { Science, Sustainable } \\
\text { Agriculture and } \\
\text { Agroindustrial } \\
\text { Engineering } \\
\text { (AFSSAAE) }\end{array}$ & 26225921 & $\begin{array}{l}\text { Universitas } \\
\text { Brawijaya }\end{array}$ & $\begin{array}{l}\text { Usulan Baru } \\
\text { mulai Volume } 1 \\
\text { Nomor } 1 \text { Tahun } \\
2018\end{array}$ \\
\hline & 2 & $\begin{array}{l}\text { Al Quds: Jurnal } \\
\text { Studi Alquran dan } \\
\text { Hadis }\end{array}$ & 25803190 & $\begin{array}{l}\text { Institut Agama } \\
\text { Islam Negeri } \\
\text { (IAIN) Curup }\end{array}$ & $\begin{array}{l}\text { Reakreditasi Naik } \\
\text { Peringkat dari } \\
\text { Peringkat } 3 \text { ke } \\
\text { Peringkat } 2 \text { mulai } \\
\text { Volume } 3 \text { Nomor } \\
2 \text { Tahun } 2019 \\
\end{array}$ \\
\hline & 3 & $\begin{array}{l}\text { Al-Bidayah: Jurnal } \\
\text { Pendidikan Dasar } \\
\text { Islam }\end{array}$ & 25493388 & $\begin{array}{l}\text { Program Studi } \\
\text { Pendidikan Guru } \\
\text { Madrasah } \\
\text { Ibtidaiyah } \\
\text { Fakultas Ilmu } \\
\text { Tarbiyah dan } \\
\text { Keguruan, } \\
\text { Universitas Islam } \\
\text { Negeri Sunan } \\
\text { Kalijaga } \\
\text { Yogyakarta } \\
\end{array}$ & $\begin{array}{l}\text { Reakreditasi Naik } \\
\text { Peringkat dari } \\
\text { Peringkat } 3 \mathrm{ke} \\
\text { Peringkat } 2 \text { mulai } \\
\text { Volume } 11 \\
\text { Nomor } 2 \text { Tahun } \\
2019\end{array}$ \\
\hline & 4 & $\begin{array}{l}\text { Al-Istinbath: Jurnal } \\
\text { Hukum Islam }\end{array}$ & 25483382 & $\begin{array}{l}\text { Institut Agama } \\
\text { Islam Negeri } \\
\text { (IAIN)) Curup }\end{array}$ & $\begin{array}{l}\text { Reakreditasi Naik } \\
\text { Peringkat dari } \\
\text { Peringkat } 3 \text { ke } \\
\text { Peringkat } 2 \text { mulai } \\
\text { Volume } 4 \text { Nomor } \\
2 \text { Tahun } 2019\end{array}$ \\
\hline & 5 & Amerta & 25498908 & $\begin{array}{l}\text { Pusat Penelitian } \\
\text { Arkeologi } \\
\text { Nasional }\end{array}$ & $\begin{array}{l}\text { Reakreditasi } \\
\text { Tetap di } \\
\text { Peringkat } 2 \text { mulai } \\
\text { Volume } 37 \\
\text { Nomor } 2 \text { Tahun } \\
2019\end{array}$ \\
\hline
\end{tabular}

6. Analisa ... 


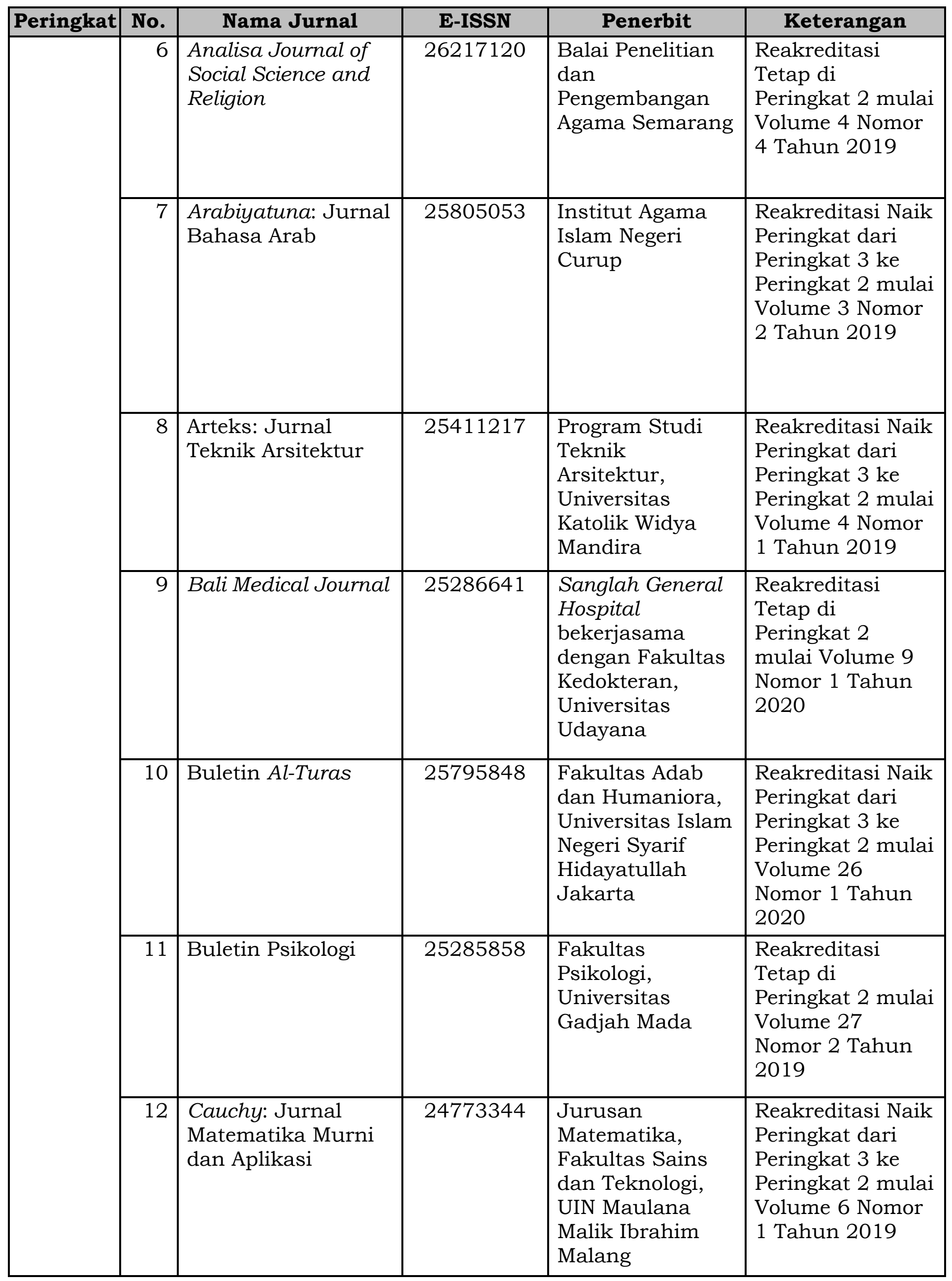




\begin{tabular}{|c|c|c|c|c|c|}
\hline \multirow[t]{9}{*}{ Peringkat } & No. & Nama Jurnal & E-ISSN & Penerbit & Keterangan \\
\hline & 13 & $\begin{array}{l}\text { Communication in } \\
\text { Biomathematical } \\
\text { Sciences }\end{array}$ & 25492896 & $\begin{array}{l}\text { Indonesian } \\
\text { Biomathematical } \\
\text { Society }\end{array}$ & $\begin{array}{l}\text { Usulan Baru } \\
\text { mulai Volume } 1 \\
\text { Nomor } 1 \text { Tahun } \\
2017\end{array}$ \\
\hline & 14 & $\begin{array}{l}\text { Communicatus: } \\
\text { Jurnal Ilmu } \\
\text { Komunikasi }\end{array}$ & 25498452 & $\begin{array}{l}\text { Fakultas Dakwah } \\
\text { dan Komunikasi, } \\
\text { UIN Sunan } \\
\text { Gunung Djati } \\
\text { Bandung }\end{array}$ & $\begin{array}{l}\text { Reakreditasi Naik } \\
\text { Peringkat dari } \\
\text { Peringkat } 3 \text { ke } \\
\text { Peringkat } 2 \text { mulai } \\
\text { Volume } 3 \text { Nomor } \\
2 \text { Tahun } 2019\end{array}$ \\
\hline & 15 & $\begin{array}{l}\text { Indigenous: Jurnal } \\
\text { Ilmiah Psikologi }\end{array}$ & $2541450 X$ & $\begin{array}{l}\text { Fakultas } \\
\text { Psikologi, } \\
\text { Universitas } \\
\text { Muhammadiyah } \\
\text { Surakarta }\end{array}$ & $\begin{array}{l}\text { Reakreditasi Naik } \\
\text { Peringkat dari } \\
\text { Peringkat } 4 \text { ke } \\
\text { Peringkat } 2 \text { mulai } \\
\text { Volume } 4 \text { Nomor } \\
2 \text { Tahun } 2019 \\
\end{array}$ \\
\hline & 16 & $\begin{array}{l}\text { Indonesian Fisheries } \\
\text { Research Journal }\end{array}$ & 25026569 & $\begin{array}{l}\text { The Center for } \\
\text { Fisheries } \\
\text { Research, } \\
\text { Indonesian } \\
\text { Ministry of Marine } \\
\text { Affairs and } \\
\text { Fisheries }\end{array}$ & $\begin{array}{l}\text { Reakreditasi } \\
\text { Tetap di } \\
\text { Peringkat } 2 \text { mulai } \\
\text { Volume } 25 \\
\text { Nomor } 2 \text { Tahun } \\
2019\end{array}$ \\
\hline & 17 & $\begin{array}{l}\text { Intensif: Jurnal } \\
\text { Penelitian dan } \\
\text { Penerapan } \\
\text { Teknologi Sistem } \\
\text { Informasi }\end{array}$ & 25496824 & $\begin{array}{l}\text { Universitas } \\
\text { Nusantara PGRI } \\
\text { Kediri }\end{array}$ & $\begin{array}{l}\text { Reakreditasi Naik } \\
\text { Peringkat dari } \\
\text { Peringkat } 3 \mathrm{ke} \\
\text { Peringkat } 2 \text { mulai } \\
\text { Volume } 4 \text { Nomor } \\
1 \text { Tahun } 2020\end{array}$ \\
\hline & 18 & $\begin{array}{l}\text { International } \\
\text { Journal of Islamic } \\
\text { Business and } \\
\text { Economics (IJIBEC) }\end{array}$ & $2615420 X$ & $\begin{array}{l}\text { Fakultas } \\
\text { Ekonomi dan } \\
\text { Bisnis Islam } \\
\text { (FEBI) IAIN } \\
\text { Pekalongan } \\
\text { Kerjasama MES } \\
\text { dan IAEI }\end{array}$ & $\begin{array}{l}\text { Reakreditasi Naik } \\
\text { Peringkat dari } \\
\text { Peringkat } 3 \mathrm{ke} \\
\text { Peringkat } 2 \text { mulai } \\
\text { Volume } 3 \text { Nomor } \\
2 \text { Tahun } 2019\end{array}$ \\
\hline & 19 & $\begin{array}{l}\text { JDM (Jurnal } \\
\text { Dinamika } \\
\text { Manajemen) }\end{array}$ & 23375434 & $\begin{array}{l}\text { Universitas } \\
\text { Negeri Semarang }\end{array}$ & $\begin{array}{l}\text { Reakreditasi } \\
\text { Tetap di } \\
\text { Peringkat } 2 \text { mulai } \\
\text { Volume } 10 \\
\text { Nomor } 2 \text { Tahun } \\
2019\end{array}$ \\
\hline & 20 & $\begin{array}{l}\text { JIPF (Jurnal Ilmu } \\
\text { Pendidikan Fisika) }\end{array}$ & 24778451 & $\begin{array}{l}\text { Institute of } \\
\text { Managing and } \\
\text { Publishing of } \\
\text { Scientific } \\
\text { Journals STKIP } \\
\text { Singkawang }\end{array}$ & $\begin{array}{l}\text { Reakreditasi Naik } \\
\text { Peringkat dari } \\
\text { Peringkat } 3 \text { ke } \\
\text { Peringkat } 2 \text { mulai } \\
\text { Volume } 5 \text { Nomor } \\
1 \text { Tahun } 2020\end{array}$ \\
\hline
\end{tabular}




\begin{tabular}{|c|c|c|c|c|c|}
\hline \begin{tabular}{|l|} 
Peringkat \\
\end{tabular} & No. & Nama Jurnal & E-ISSN & Penerbit & Keterangan \\
\hline \multirow{8}{*}{ | } & 21 & $\begin{array}{l}\text { Journal of the Civil } \\
\text { Engineering Forum }\end{array}$ & 25495925 & $\begin{array}{l}\text { Departemen } \\
\text { Teknik Sipil dan } \\
\text { Lingkungan } \\
\text { Universitas } \\
\text { Gadjah Mada }\end{array}$ & $\begin{array}{l}\text { Reakreditasi } \\
\text { Tetap di } \\
\text { Peringkat } 2 \text { mulai } \\
\text { Volume } 6 \text { Nomor } \\
1 \text { Tahun } 2020\end{array}$ \\
\hline & 22 & $\begin{array}{l}\text { Jurnal Ekonomi } \\
\text { dan Keuangan } \\
\text { Islam }\end{array}$ & 26146908 & $\begin{array}{l}\text { Pusat Pengkajian } \\
\text { dan } \\
\text { Pengembangan } \\
\text { Ekonomi Islam } \\
\text { (P3EI), Fakultas } \\
\text { Ekonomi, } \\
\text { Universitas Islam } \\
\text { Indonesia }\end{array}$ & $\begin{array}{l}\text { Reakreditasi Naik } \\
\text { Peringkat dari } \\
\text { Peringkat } 3 \mathrm{ke} \\
\text { Peringkat } 2 \text { mulai } \\
\text { Volume } 6 \text { Nomor } \\
1 \text { Tahun } 2020\end{array}$ \\
\hline & 23 & $\begin{array}{l}\text { Jurnal Fitopatologi } \\
\text { Indonesia }\end{array}$ & 23392479 & $\begin{array}{l}\text { Perhimpunan } \\
\text { Fitopatologi } \\
\text { Indonesia }\end{array}$ & $\begin{array}{l}\text { Reakreditasi } \\
\text { Tetap di } \\
\text { Peringkat } 2 \text { mulai } \\
\text { Volume } 16 \\
\text { Nomor } 1 \text { Tahun } \\
2020\end{array}$ \\
\hline & 24 & $\begin{array}{l}\text { Jurnal Ilmiah } \\
\text { Akuntansi dan } \\
\text { Bisnis }\end{array}$ & 23031018 & $\begin{array}{l}\text { Fakultas } \\
\text { Ekonomi dan } \\
\text { Bisnis } \\
\text { Universitas } \\
\text { Udayana }\end{array}$ & $\begin{array}{l}\text { Reakreditasi } \\
\text { Tetap di } \\
\text { Peringkat } 2 \text { mulai } \\
\text { Volume } 15 \\
\text { Nomor } 1 \text { Tahun } \\
2020\end{array}$ \\
\hline & 25 & $\begin{array}{l}\text { Jurnal Ilmiah } \\
\text { Al-Syir'ah }\end{array}$ & 25280368 & $\begin{array}{l}\text { Fakultas Syariah } \\
\text { IAIN Manado }\end{array}$ & $\begin{array}{l}\text { Reakreditasi Naik } \\
\text { Peringkat dari } \\
\text { Peringkat } 3 \text { ke } \\
\text { Peringkat } 2 \text { mulai } \\
\text { Volume } 17 \\
\text { Nomor } 2 \text { Tahun } \\
2019\end{array}$ \\
\hline & 26 & $\begin{array}{l}\text { Jurnal Ilmu } \\
\text { Kehutanan }\end{array}$ & 24773751 & $\begin{array}{l}\text { Universitas } \\
\text { Gadjah Mada }\end{array}$ & $\begin{array}{l}\text { Reakreditasi } \\
\text { Tetap di } \\
\text { Peringkat } 2 \text { mulai } \\
\text { Volume } 13 \\
\text { Nomor } 2 \text { Tahun } \\
2019\end{array}$ \\
\hline & 27 & $\begin{array}{l}\text { Jurnal Ilmu } \\
\text { Komunikasi }\end{array}$ & 25488643 & $\begin{array}{l}\text { Prodi Ilmu } \\
\text { Komunikasi } \\
\text { FISIP Universitas } \\
\text { Atma Jaya } \\
\text { Yogyakarta }\end{array}$ & $\begin{array}{l}\text { Reakreditasi } \\
\text { Tetap di } \\
\text { Peringkat } 2 \text { mulai } \\
\text { Volume } 16 \\
\text { Nomor } 2 \text { Tahun } \\
2019\end{array}$ \\
\hline & 28 & $\begin{array}{l}\text { Jurnal Iqra': Kajian } \\
\text { Ilmu Pendidikan }\end{array}$ & 25487892 & $\begin{array}{l}\text { Fakultas } \\
\text { Tarbiyah IAI } \\
\text { Ma'arif NU Metro } \\
\text { Lampung }\end{array}$ & $\begin{array}{l}\text { Reakreditasi Naik } \\
\text { Peringkat dari } \\
\text { Peringkat } 3 \text { ke } \\
\text { Peringkat } 2 \text { mulai } \\
\text { Volume } 4 \text { Nomor } \\
2 \text { Tahun } 2019\end{array}$ \\
\hline
\end{tabular}




\begin{tabular}{|c|c|c|c|c|c|}
\hline Peringkat & No. & Nama Jurnal & E-ISSN & Penerbit & Keterangan \\
\hline \multirow{8}{*}{ 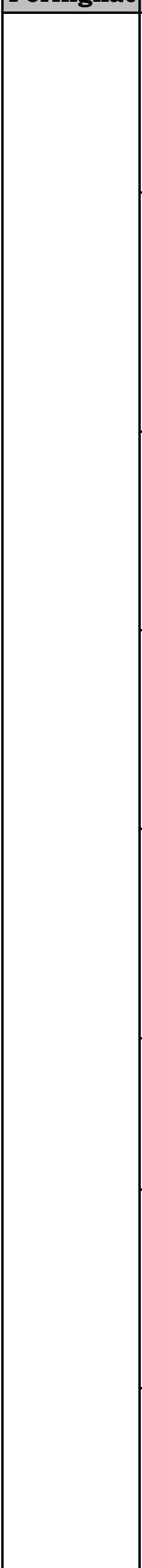 } & 29 & $\begin{array}{l}\text { Jurnal } \\
\text { Jurisprudence }\end{array}$ & 25495615 & $\begin{array}{l}\text { Program Magister } \\
\text { Ilmu Hukum, } \\
\text { Universitas } \\
\text { Muhammadiyah } \\
\text { Surakarta }\end{array}$ & $\begin{array}{l}\text { Reakreditasi Naik } \\
\text { Peringkat dari } \\
\text { Peringkat } 4 \text { ke } \\
\text { Peringkat } 2 \text { mulai } \\
\text { Volume } 9 \text { Nomor } \\
2 \text { Tahun } 2019 \\
\end{array}$ \\
\hline & 30 & $\begin{array}{l}\text { Jurnal Kebijakan } \\
\text { dan Administrasi } \\
\text { Publik }\end{array}$ & 24774693 & $\begin{array}{l}\text { Magister } \\
\text { Administrasi } \\
\text { Publik (MAP) } \\
\text { Fakultas Ilmu } \\
\text { Sosial dan Ilmu } \\
\text { Politik } \\
\text { Universitas } \\
\text { Gadjah Mada } \\
\end{array}$ & $\begin{array}{l}\text { Reakreditasi } \\
\text { Tetap di } \\
\text { Peringkat } 2 \text { mulai } \\
\text { Volume } 23 \\
\text { Nomor } 2 \text { Tahun } \\
2019\end{array}$ \\
\hline & 31 & $\begin{array}{l}\text { Jurnal Kebijakan } \\
\text { Perikanan } \\
\text { Indonesia }\end{array}$ & 25026550 & $\begin{array}{l}\text { Pusat Riset } \\
\text { Perikanan } \\
\text { Kementerian } \\
\text { Kelautan dan } \\
\text { Perikanan }\end{array}$ & $\begin{array}{l}\text { Reakreditasi } \\
\text { Tetap di } \\
\text { Peringkat } 2 \text { mulai } \\
\text { Volume } 11 \\
\text { Nomor } 2 \text { Tahun } \\
2019\end{array}$ \\
\hline & 32 & $\begin{array}{l}\text { Jurnal Kelautan } \\
\text { Nasional }\end{array}$ & 26154579 & $\begin{array}{l}\text { Pusat Riset } \\
\text { Kelautan } \\
\text { Kementerian } \\
\text { Kelautan dan } \\
\text { Perikanan }\end{array}$ & $\begin{array}{l}\text { Reakreditasi } \\
\text { Tetap di } \\
\text { Peringkat } 2 \text { mulai } \\
\text { Volume } 14 \\
\text { Nomor } 3 \text { Tahun } \\
2019\end{array}$ \\
\hline & 33 & Jurnal Komunikasi & 25282727 & $\begin{array}{l}\text { Fakultas Ilmu } \\
\text { Komunikasi } \\
\text { Universitas } \\
\text { Tarumanagara }\end{array}$ & $\begin{array}{l}\text { Reakreditasi Naik } \\
\text { Peringkat dari } \\
\text { Peringkat } 3 \mathrm{ke} \\
\text { Peringkat } 2 \text { mulai } \\
\text { Volume } 11 \\
\text { Nomor } 2 \text { Tahun } \\
2019\end{array}$ \\
\hline & 34 & $\begin{array}{l}\text { Jurnal Manajemen } \\
\text { dan Pelayanan } \\
\text { Farmasi (Journal of } \\
\text { Management and } \\
\text { Pharmacy Practice) } \\
\end{array}$ & 24432946 & $\begin{array}{l}\text { Universitas } \\
\text { Gadjah Mada }\end{array}$ & $\begin{array}{l}\text { Reakreditasi } \\
\text { Tetap di } \\
\text { Peringkat } 2 \text { mulai } \\
\text { Volume } 9 \text { Nomor } \\
\text { 4 Tahun } 2019 \\
\end{array}$ \\
\hline & 35 & Jurnal Ners & 25025791 & $\begin{array}{l}\text { Fakultas } \\
\text { Keperawatan } \\
\text { Universitas } \\
\text { Airlangga }\end{array}$ & $\begin{array}{l}\text { Reakreditasi } \\
\text { Tetap di } \\
\text { Peringkat } 2 \text { mulai } \\
\text { Volume } 14 \\
\text { Nomor } 2 \text { Tahun } \\
2019\end{array}$ \\
\hline & 36 & $\begin{array}{l}\text { Jurnal Pendidikan } \\
\text { Jasmani dan } \\
\text { Olahraga }\end{array}$ & $2580071 \mathrm{X}$ & $\begin{array}{l}\text { Departemen } \\
\text { Pendidikan } \\
\text { Olahraga FPOK } \\
\text { Universitas } \\
\text { Pendidikan } \\
\text { Indonesia }\end{array}$ & $\begin{array}{l}\text { Reakreditasi Naik } \\
\text { Peringkat dari } \\
\text { Peringkat } 3 \text { ke } \\
\text { Peringkat } 2 \text { mulai } \\
\text { Volume } 4 \text { Nomor } \\
2 \text { Tahun } 2019\end{array}$ \\
\hline
\end{tabular}




\begin{tabular}{|c|c|c|c|c|c|}
\hline \begin{tabular}{|l|} 
Peringkat \\
\end{tabular} & No. & Nama Jurnal & E-ISSN & Penerbit & Keterangan \\
\hline & 37 & $\begin{array}{l}\text { Jurnal Pendidikan } \\
\text { Kedokteran } \\
\text { Indonesia: The } \\
\text { Indonesian Journal } \\
\text { of Medical Education }\end{array}$ & 26545810 & $\begin{array}{l}\text { Asosiasi Institusi } \\
\text { Pendidikan } \\
\text { Kedokteran } \\
\text { Indonesia }\end{array}$ & $\begin{array}{l}\text { Usulan Baru } \\
\text { mulai Volume } 3 \\
\text { Nomor } 1 \text { Tahun } \\
2019\end{array}$ \\
\hline & 38 & $\begin{array}{l}\text { Jurnal Pendidikan } \\
\text { Vokasi }\end{array}$ & 24769401 & $\begin{array}{l}\text { Asosiasi Dosen } \\
\text { dan Guru Vokasi } \\
\text { Indonesia dan } \\
\text { Program } \\
\text { Pascasarjana } \\
\text { Universitas } \\
\text { Negeri } \\
\text { Yogyakarta }\end{array}$ & $\begin{array}{l}\text { Reakreditasi } \\
\text { Tetap di } \\
\text { Peringkat } 2 \text { mulai } \\
\text { Volume } 9 \text { Nomor } \\
3 \text { Tahun } 2019\end{array}$ \\
\hline & 39 & $\begin{array}{l}\text { Jurnal Pengolahan } \\
\text { Hasil Perikanan } \\
\text { Indonesia }\end{array}$ & $2354886 \mathrm{X}$ & $\begin{array}{l}\text { Masyarakat } \\
\text { Pengolahan Hasil } \\
\text { Perikanan } \\
\text { Indonesia }\end{array}$ & $\begin{array}{l}\text { Reakreditasi } \\
\text { Tetap di } \\
\text { Peringkat } 2 \text { mulai } \\
\text { Volume } 2 \text { Nomor } \\
3 \text { Tahun } 2019\end{array}$ \\
\hline & 40 & $\begin{array}{l}\text { Jurnal Psikologi } \\
\text { Ulayat: Indonesian } \\
\text { Journal of } \\
\text { Indigenous } \\
\text { Psychology }\end{array}$ & 25801228 & $\begin{array}{l}\text { Konsorsium } \\
\text { Psikologi Ilmiah } \\
\text { Nusantara (KPIN) }\end{array}$ & $\begin{array}{l}\text { Reakreditasi Naik } \\
\text { Peringkat dari } \\
\text { Peringkat } 3 \text { ke } \\
\text { Peringkat } 2 \text { mulai } \\
\text { Volume } 6 \text { Nomor } \\
2 \text { Tahun } 2019\end{array}$ \\
\hline & 41 & $\begin{array}{l}\text { Jurnal Sain } \\
\text { Veteriner }\end{array}$ & 24073733 & $\begin{array}{l}\text { Universitas } \\
\text { Gadjah Mada }\end{array}$ & $\begin{array}{l}\text { Reakreditasi } \\
\text { Tetap di } \\
\text { Peringkat } 2 \text { mulai } \\
\text { Volume } 37 \\
\text { Nomor } 2 \text { Tahun } \\
2019\end{array}$ \\
\hline & 42 & $\begin{array}{l}\text { Jurnal SMaRT } \\
\text { (Studi Masyarakat } \\
\text { Religi dan Tradisi) }\end{array}$ & $2528553 X$ & $\begin{array}{l}\text { Balai Penelitian } \\
\text { dan } \\
\text { Pengembangan } \\
\text { Agama Semarang }\end{array}$ & $\begin{array}{l}\text { Reakreditasi } \\
\text { Tetap di } \\
\text { Peringkat } 2 \text { mulai } \\
\text { Volume } 5 \text { Nomor } \\
2 \text { Tahun } 2019 \\
\end{array}$ \\
\hline & 43 & $\begin{array}{l}\text { Jurnal Studi Ilmu- } \\
\text { Ilmu Al-Qur'an dan } \\
\text { Hadis }\end{array}$ & 25484737 & $\begin{array}{l}\text { Program Studi } \\
\text { Ilmu al-Qur'an } \\
\text { dan Tafsir UIN } \\
\text { Sunan Kalijaga } \\
\text { Yogyakarta }\end{array}$ & $\begin{array}{l}\text { Reakreditasi Naik } \\
\text { Peringkat dari } \\
\text { Peringkat } 3 \text { ke } \\
\text { Peringkat } 2 \text { mulai } \\
\text { Volume } 21 \\
\text { Nomor } 1 \text { Tahun } \\
2020\end{array}$ \\
\hline & 44 & $\begin{array}{l}\text { Knowledge } \\
\text { Engineering and } \\
\text { Data Science }\end{array}$ & 25974637 & $\begin{array}{l}\text { Jurusan Teknik } \\
\text { Elektro, Program } \\
\text { Studi Teknik } \\
\text { Informatika, } \\
\text { Universitas } \\
\text { Negeri Malang }\end{array}$ & $\begin{array}{l}\text { Usulan Baru } \\
\text { mulai Volume } 1 \\
\text { Nomor } 1 \text { Tahun } \\
2018\end{array}$ \\
\hline
\end{tabular}

45. Konseling ... 


\begin{tabular}{|c|c|c|c|c|c|}
\hline Peringkat & No. & Nama Jurnal & E-ISSN & Penerbit & Keterangan \\
\hline & 45 & $\begin{array}{l}\text { Konseling Religi } \\
\text { Jurnal Bimbingan } \\
\text { Konseling Islam }\end{array}$ & 24772100 & $\begin{array}{l}\text { Prodi Bimbingan } \\
\text { dan Konseling } \\
\text { Islam Jurusan } \\
\text { Dakwah dan } \\
\text { Komunikasi } \\
\text { STAIN Kudus }\end{array}$ & $\begin{array}{l}\text { Reakreditasi } \\
\text { Tetap di } \\
\text { Peringkat } 2 \text { mulai } \\
\text { Volume } 10 \\
\text { Nomor } 2 \text { Tahun } \\
2019\end{array}$ \\
\hline & 46 & $\begin{array}{l}\text { Majalah Kedokteran } \\
\text { Gigi Indonesia }\end{array}$ & 24422576 & $\begin{array}{l}\text { Fakultas } \\
\text { Kedokteran Gigi } \\
\text { Universitas } \\
\text { Gadjah Mada }\end{array}$ & $\begin{array}{l}\text { Reakreditasi } \\
\text { Tetap di } \\
\text { Peringkat } 2 \text { mulai } \\
\text { Volume } 5 \text { Nomor } \\
3 \text { Tahun } 2019\end{array}$ \\
\hline & 47 & $\begin{array}{l}\text { Majalah Obat } \\
\text { Tradisional }\end{array}$ & 24069086 & $\begin{array}{l}\text { Fakultas Farmasi } \\
\text { Universitas } \\
\text { Gadjah Mada }\end{array}$ & $\begin{array}{l}\text { Reakreditasi } \\
\text { Tetap di } \\
\text { Peringkat } 2 \text { mulai } \\
\text { Volume } 24 \\
\text { Nomor } 3 \text { Tahun } \\
2019\end{array}$ \\
\hline & 48 & Media Akuakultur & 25029460 & $\begin{array}{l}\text { Pusat Riset } \\
\text { Perikanan } \\
\text { Kementerian } \\
\text { Kelautan dan } \\
\text { Perikanan }\end{array}$ & $\begin{array}{l}\text { Reakreditasi } \\
\text { Tetap di } \\
\text { Peringkat } 2 \text { mulai } \\
\text { Volume } 14 \\
\text { Nomor } 2 \text { Tahun } \\
2019\end{array}$ \\
\hline & 49 & $\begin{array}{l}\text { MIX: Jurnal Ilmiah } \\
\text { Manajemen }\end{array}$ & 24605328 & $\begin{array}{l}\text { Universitas } \\
\text { Mercu Buana }\end{array}$ & $\begin{array}{l}\text { Reakreditasi } \\
\text { Tetap di } \\
\text { Peringkat } 2 \text { mulai } \\
\text { Volume } 10 \\
\text { Nomor } 1 \text { Tahun } \\
2020\end{array}$ \\
\hline & 50 & $\begin{array}{l}\text { Muwazah: Jurnal } \\
\text { Kajian Gender }\end{array}$ & 25025368 & $\begin{array}{l}\text { Institut Agama } \\
\text { Islam Negeri } \\
\text { Pekalongan }\end{array}$ & $\begin{array}{l}\text { Reakreditasi Naik } \\
\text { Peringkat dari } \\
\text { Peringkat } 3 \text { ke } \\
\text { Peringkat } 2 \text { mulai } \\
\text { Volume } 11 \\
\text { Nomor } 2 \text { Tahun } \\
2019\end{array}$ \\
\hline & 51 & $\begin{array}{l}\text { Signifikan: Jurnal } \\
\text { Ilmu Ekonomi }\end{array}$ & 24769223 & $\begin{array}{l}\text { Universitas Islam } \\
\text { Negeri Syarif } \\
\text { Hidayatullah } \\
\text { Jakarta }\end{array}$ & $\begin{array}{l}\text { Reakreditasi } \\
\text { Tetap di } \\
\text { Peringkat } 2 \text { mulai } \\
\text { Volume } 8 \text { Nomor } \\
2 \text { Tahun } 2019\end{array}$ \\
\hline & 52 & $\begin{array}{l}\text { Substantive Justice } \\
\text { International } \\
\text { Journal of Law }\end{array}$ & 25990462 & $\begin{array}{l}\text { Fakultas Hukum, } \\
\text { Universitas } \\
\text { Muslim } \\
\text { Indonesia }\end{array}$ & $\begin{array}{l}\text { Usulan Baru } \\
\text { mulai Volume } 1 \\
\text { Nomor } 1 \text { Tahun } \\
2018\end{array}$ \\
\hline & 53 & $\begin{array}{l}\text { Sustinere: Journal } \\
\text { of Environment and } \\
\text { Sustainability }\end{array}$ & 25491253 & $\begin{array}{l}\text { Centre for Science } \\
\text { and Technology, } \\
\text { IAIN Surakarta }\end{array}$ & $\begin{array}{l}\text { Usulan Baru } \\
\text { mulai Volume } 2 \\
\text { Nomor } 1 \text { Tahun } \\
2018\end{array}$ \\
\hline
\end{tabular}




\begin{tabular}{|c|c|c|c|c|c|}
\hline Peringkat & No. & Nama Jurnal & E-ISSN & Penerbit & Keterangan \\
\hline & 54 & Telematika & 24424528 & $\begin{array}{l}\text { Universitas } \\
\text { Amikom } \\
\text { Purwokerto }\end{array}$ & $\begin{array}{l}\text { Reakreditasi Naik } \\
\text { Peringkat dari } \\
\text { Peringkat } 3 \text { ke } \\
\text { Peringkat } 2 \text { mulai } \\
\text { Volume } 13 \\
\text { Nomor } 1 \text { Tahun } \\
2020\end{array}$ \\
\hline & 55 & $\begin{array}{l}\text { Wartazoa: Buletin } \\
\text { Ilmu Peternakan } \\
\text { dan Kesehatan } \\
\text { Hewan Indonesia }\end{array}$ & 23546832 & $\begin{array}{l}\text { Pusat Penelitian } \\
\text { dan } \\
\text { Pengembangan } \\
\text { Peternakan } \\
\text { Kementerian } \\
\text { Pertanian }\end{array}$ & $\begin{array}{l}\text { Reakreditasi } \\
\text { Tetap di } \\
\text { Peringkat } 2 \text { mulai } \\
\text { Volume } 29 \\
\text { Nomor } 4 \text { Tahun } \\
2019\end{array}$ \\
\hline \multirow[t]{7}{*}{3} & 1 & $\begin{array}{l}\text { Academia Praja: } \\
\text { Jurnal Ilmu Politik, } \\
\text { Pemerintahan dan } \\
\text { Administrasi Publik }\end{array}$ & 27159124 & $\begin{array}{l}\text { Universitas } \\
\text { Jenderal Achmad } \\
\text { Yani }\end{array}$ & $\begin{array}{l}\text { Usulan Baru } \\
\text { mulai Volume } 1 \\
\text { Nomor } 2 \text { Tahun } \\
2018\end{array}$ \\
\hline & 2 & $\begin{array}{l}\text { Aceh Journal of } \\
\text { Animal Science }\end{array}$ & 26228734 & $\begin{array}{l}\text { Fakultas } \\
\text { Kelautan dan } \\
\text { Perikanan } \\
\text { Universitas Syiah } \\
\text { Kuala }\end{array}$ & $\begin{array}{l}\text { Reakreditasi } \\
\text { Tetap di } \\
\text { Peringkat } 3 \text { mulai } \\
\text { Volume } 4 \text { Nomor } \\
2 \text { Tahun } 2019 \\
\end{array}$ \\
\hline & 3 & $\begin{array}{l}\text { Acta Biochimica } \\
\text { Indonesiana }\end{array}$ & 26543222 & $\begin{array}{l}\text { Perhimpunan } \\
\text { Biokimia dan } \\
\text { Biologi Molekuler } \\
\text { Indonesia }\end{array}$ & $\begin{array}{l}\text { Usulan Baru } \\
\text { mulai Volume } 1 \\
\text { Nomor } 1 \text { Tahun } \\
2018\end{array}$ \\
\hline & 4 & Acta Chimica Asiana & 25500503 & $\begin{array}{l}\text { Universitas } \\
\text { Mataram }\end{array}$ & $\begin{array}{l}\text { Usulan Baru } \\
\text { mulai Volume } 1 \\
\text { Nomor } 2 \text { Tahun } \\
2018\end{array}$ \\
\hline & 5 & $\begin{array}{l}\text { Agregat: Jurnal } \\
\text { Ekonomi dan Bisnis }\end{array}$ & 25497243 & $\begin{array}{l}\text { Fakultas } \\
\text { Ekonomi dan } \\
\text { Bisnis } \\
\text { Universitas } \\
\text { Muhammadiyah } \\
\text { Prof. DR. HAMKA }\end{array}$ & $\begin{array}{l}\text { Reakreditasi Naik } \\
\text { Peringkat dari } \\
\text { Peringkat } 4 \text { ke } \\
\text { Peringkat } 3 \text { mulai } \\
\text { Volume } 3 \text { Nomor } \\
2 \text { Tahun } 2019\end{array}$ \\
\hline & 6 & $\begin{array}{l}\text { Agrikan: Jurnal } \\
\text { Agribisnis } \\
\text { Perikanan }\end{array}$ & 26210193 & $\begin{array}{l}\text { Sekolah Tinggi } \\
\text { Ilmu Pertanian } \\
\text { Wuna Raha }\end{array}$ & $\begin{array}{l}\text { Reakreditasi Naik } \\
\text { Peringkat dari } \\
\text { Peringkat } 4 \text { ke } \\
\text { Peringkat } 3 \text { mulai } \\
\text { Volume } 12 \\
\text { Nomor } 2 \text { Tahun } \\
2019\end{array}$ \\
\hline & 7 & Agroteknika & 26853450 & $\begin{array}{l}\text { Politeknik } \\
\text { Pertaninan } \\
\text { Negeri } \\
\text { Payakumbuh }\end{array}$ & $\begin{array}{l}\text { Usulan Baru } \\
\text { mulai Volume } 1 \\
\text { Nomor } 1 \text { Tahun } \\
2018\end{array}$ \\
\hline
\end{tabular}




\begin{tabular}{|c|c|c|c|c|c|}
\hline \begin{tabular}{|l|} 
Peringkat \\
\end{tabular} & No. & Nama Jurnal & E-ISSN & Penerbit & Keterangan \\
\hline & 8 & $\begin{array}{l}\text { Agrovigor: Jurnal } \\
\text { Agroekoteknologi }\end{array}$ & 24770353 & $\begin{array}{l}\text { Program Studi } \\
\text { Agroekoteknologi, } \\
\text { Universitas } \\
\text { Trunojoyo } \\
\text { Madura }\end{array}$ & $\begin{array}{l}\text { Reakreditasi Naik } \\
\text { Peringkat dari } \\
\text { Peringkat } 4 \text { ke } \\
\text { Peringkat } 3 \text { mulai } \\
\text { Volume } 12 \\
\text { Nomor } 2 \text { Tahun } \\
2019\end{array}$ \\
\hline & 9 & $\begin{array}{l}\text { AJIS: Academic } \\
\text { Journal of Islamic } \\
\text { Studies }\end{array}$ & 25483285 & $\begin{array}{l}\text { Institut Agama } \\
\text { Islam Negeri } \\
\text { (IAIN) Curup }\end{array}$ & $\begin{array}{l}\text { Reakreditasi Naik } \\
\text { Peringkat dari } \\
\text { Peringkat } 4 \text { ke } \\
\text { Peringkat } 3 \text { mulai } \\
\text { Volume } 4 \text { Nomor } \\
2 \text { Tahun } 2019\end{array}$ \\
\hline & 10 & $\begin{array}{l}\text { Alchemy: Journal of } \\
\text { Chemistry }\end{array}$ & 24606871 & $\begin{array}{l}\text { Jurusan Kimia } \\
\text { Fakultas Sains } \\
\text { dan Teknologi } \\
\text { Universitas Islam } \\
\text { Negeri Maulana } \\
\text { Malik Ibrahim } \\
\text { Malang } \\
\end{array}$ & $\begin{array}{l}\text { Usulan Baru } \\
\text { mulai Volume } 6 \\
\text { Nomor } 1 \text { Tahun } \\
2018\end{array}$ \\
\hline & 11 & $\begin{array}{l}\text { Al-Falah: Journal of } \\
\text { Islamic Economics }\end{array}$ & 25483102 & $\begin{array}{l}\text { Institut Agama } \\
\text { Islam Negari } \\
\text { (IAIN), Curup- } \\
\text { Bengkulu }\end{array}$ & $\begin{array}{l}\text { Reakreditasi Naik } \\
\text { Peringkat dari } \\
\text { Peringkat } 4 \text { ke } \\
\text { Peringkat } 3 \text { mulai } \\
\text { Volume } 4 \text { Nomor } \\
2 \text { Tahun } 2019 \\
\end{array}$ \\
\hline & 12 & Al-Kimia & 25499335 & $\begin{array}{l}\text { Jurusan Kimia } \\
\text { Fak. Sains dan } \\
\text { Teknologi } \\
\text { Universitas Islam } \\
\text { Negeri Alauddin } \\
\text { Makassar }\end{array}$ & $\begin{array}{l}\text { Reakreditasi } \\
\text { Tetap di } \\
\text { Peringkat } 3 \text { mulai } \\
\text { Volume } 7 \text { Nomor } \\
2 \text { Tahun } 2019\end{array}$ \\
\hline & 13 & $\begin{array}{l}\text { Al-Tanzim: Jurnal } \\
\text { Manajemen } \\
\text { Pendidikan Islam }\end{array}$ & 25495720 & $\begin{array}{l}\text { FAI Universitas } \\
\text { Nurul Jadid }\end{array}$ & $\begin{array}{l}\text { Reakreditasi } \\
\text { Tetap di } \\
\text { Peringkat } 3 \text { mulai } \\
\text { Volume } 3 \text { Nomor } \\
2 \text { Tahun } 2019 \\
\end{array}$ \\
\hline & 14 & $\begin{array}{l}\text { Al-Tazkiah: Jurnal } \\
\text { Bimbingan dan } \\
\text { Konseling Islam }\end{array}$ & 25412663 & $\begin{array}{l}\text { Jurusan BKI, } \\
\text { Fakultas Dakwah } \\
\text { dan Ilmu } \\
\text { Komunikasi, } \\
\text { Universitas Islam } \\
\text { Negeri Mataram }\end{array}$ & $\begin{array}{l}\text { Usulan Baru } \\
\text { mulai Volume } 7 \\
\text { Nomor } 1 \text { Tahun } \\
2018\end{array}$ \\
\hline & 15 & $\begin{array}{l}\text { An-Nisbah: Jurnal } \\
\text { Ekonomi Syariah }\end{array}$ & 25495712 & $\begin{array}{l}\text { Fakultas } \\
\text { Ekonomi dan } \\
\text { Bisnis Islam } \\
\text { Institut Agama } \\
\text { Islam Negeri } \\
\text { Tulungagung }\end{array}$ & $\begin{array}{l}\text { Reakreditasi Naik } \\
\text { Peringkat dari } \\
\text { Peringkat } 4 \text { ke } \\
\text { Peringkat } 3 \text { mulai } \\
\text { Volume } 6 \text { Nomor } \\
2 \text { Tahun } 2019\end{array}$ \\
\hline
\end{tabular}




\begin{tabular}{|c|c|c|c|c|c|}
\hline \begin{tabular}{|l|} 
Peringkat \\
\end{tabular} & No. & Nama Jurnal & E-ISSN & Penerbit & Keterangan \\
\hline & 16 & $\begin{array}{l}\text { Asia Pacific Fraud } \\
\text { Journal }\end{array}$ & $2502695 X$ & $\begin{array}{l}\text { Association of } \\
\text { Certified Fraud } \\
\text { Examiners } \\
\text { Indonesia } \\
\text { Chapter }\end{array}$ & $\begin{array}{l}\text { Usulan Baru } \\
\text { mulai Volume } 3 \\
\text { Nomor } 1 \text { Tahun } \\
2018\end{array}$ \\
\hline & 17 & $\begin{array}{l}\text { At-Turas: Jurnal } \\
\text { Studi Keislaman }\end{array}$ & 24601063 & $\begin{array}{l}\text { Lembaga } \\
\text { Penerbitan, } \\
\text { Penelitian, dan } \\
\text { Pengabdian } \\
\text { kepada } \\
\text { Masyarakat } \\
\text { (LP3M) } \\
\text { Universitas Nurul } \\
\text { Jadid }\end{array}$ & $\begin{array}{l}\text { Reakreditasi } \\
\text { Tetap di } \\
\text { Peringkat } 3 \text { mulai } \\
\text { Volume } 6 \text { Nomor } \\
2 \text { Tahun } 2018\end{array}$ \\
\hline & 18 & $\begin{array}{l}\text { Bioedusains: Jurnal } \\
\text { Pendidikan Biologi } \\
\text { dan Sains }\end{array}$ & 25987453 & $\begin{array}{l}\text { Institut } \\
\text { Penelitian } \\
\text { Matematika, } \\
\text { Komputer, } \\
\text { Keperawatan, } \\
\text { Pendidikan dan } \\
\text { Ekonomi } \\
\text { (IPM2KPE) } \\
\end{array}$ & $\begin{array}{l}\text { Usulan Baru } \\
\text { mulai Volume } 1 \\
\text { Nomor } 1 \text { Tahun } \\
2018\end{array}$ \\
\hline & 19 & $\begin{array}{l}\text { BioLink (Jurnal } \\
\text { Biologi Lingkungan, } \\
\text { Industri, Kesehatan) }\end{array}$ & 25975269 & $\begin{array}{l}\text { Fakultas Biologi } \\
\text { Universitas } \\
\text { Medan Area }\end{array}$ & $\begin{array}{l}\text { Reakreditasi } \\
\text { Tetap di } \\
\text { Peringkat } 3 \text { mulai } \\
\text { Volume } 6 \text { Nomor } \\
2 \text { Tahun } 2020\end{array}$ \\
\hline & 20 & $\begin{array}{l}\text { Bioscientia } \\
\text { Medicina: Journal of } \\
\text { Biomedicine and } \\
\text { Translational } \\
\text { Research } \\
\end{array}$ & 25980580 & $\begin{array}{l}\text { Fakultas } \\
\text { Kedokteran } \\
\text { Universitas } \\
\text { Sriwijaya }\end{array}$ & $\begin{array}{l}\text { Usulan Baru } \\
\text { mulai Volume } 2 \\
\text { Nomor } 2 \text { Tahun } \\
2018\end{array}$ \\
\hline & 21 & $\begin{array}{l}\text { Bioscientist: Jurnal } \\
\text { Ilmiah Biologi }\end{array}$ & 26544571 & IKIP Mataram & $\begin{array}{l}\text { Usulan Baru } \\
\text { mulai Volume } 6 \\
\text { Nomor } 1 \text { Tahun } \\
2018\end{array}$ \\
\hline & 22 & $\begin{array}{l}\text { Caradde: Jurnal } \\
\text { Pengabdian Kepada } \\
\text { Masyarakat }\end{array}$ & 26217910 & $\begin{array}{l}\text { Institute for } \\
\text { Learning } \\
\text { Innovation and } \\
\text { Counseling }\end{array}$ & $\begin{array}{l}\text { Usulan Baru } \\
\text { mulai Volume } 1 \\
\text { Nomor } 1 \text { Tahun } \\
2018\end{array}$ \\
\hline & 23 & $\begin{array}{l}\text { Cheesa: Chemical } \\
\text { Engineering } \\
\text { Research Articles }\end{array}$ & 26152347 & $\begin{array}{l}\text { Universitas PGRI } \\
\text { Madiun }\end{array}$ & $\begin{array}{l}\text { Usulan Baru } \\
\text { mulai Volume } 1 \\
\text { Nomor } 1 \text { Tahun } \\
2018\end{array}$ \\
\hline & 24 & $\begin{array}{l}\text { Chemica Jurnal } \\
\text { Teknik Kimia }\end{array}$ & 23558776 & $\begin{array}{l}\text { Program Studi } \\
\text { Teknik Kimia, } \\
\text { Fakultas } \\
\text { Teknologi } \\
\text { Industri, } \\
\text { Universitas } \\
\text { Ahmad Dahlan }\end{array}$ & $\begin{array}{l}\text { Reakreditasi Naik } \\
\text { Peringkat dari } \\
\text { Peringkat } 4 \mathrm{ke} \\
\text { Peringkat } 3 \text { mulai } \\
\text { Volume } 6 \text { Nomor } \\
2 \text { Tahun } 2019\end{array}$ \\
\hline
\end{tabular}




\begin{tabular}{|c|c|c|c|c|c|}
\hline Peringkat & No. & Nama Jurnal & E-ISSN & Penerbit & Keterangan \\
\hline \multirow[t]{8}{*}{ 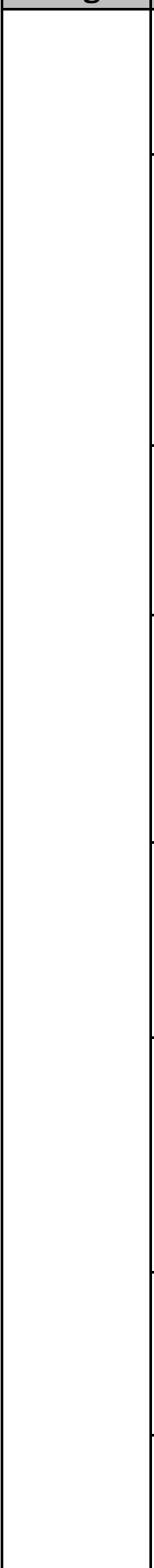 } & 25 & $\begin{array}{l}\text { Cropsaver: Journal } \\
\text { of Plant Protection }\end{array}$ & 26215756 & $\begin{array}{l}\text { Universitas } \\
\text { Padjadjaran }\end{array}$ & $\begin{array}{l}\text { Usulan Baru } \\
\text { mulai Volume } 1 \\
\text { Nomor } 1 \text { Tahun } \\
2018\end{array}$ \\
\hline & 26 & $\begin{array}{l}\text { Dayah: Journal of } \\
\text { Islamic Education }\end{array}$ & 26142694 & $\begin{array}{l}\text { Pusat Penelitian } \\
\text { dan Penerbitan, } \\
\text { Lembaga } \\
\text { Penelitian dan } \\
\text { Pengabdian } \\
\text { kepada } \\
\text { Masyarakat } \\
\text { (LP2M) UIN Ar- } \\
\text { Raniry } \\
\end{array}$ & $\begin{array}{l}\text { Usulan Baru } \\
\text { mulai Volume } 1 \\
\text { Nomor } 2 \text { Tahun } \\
2018\end{array}$ \\
\hline & 27 & $\begin{array}{l}\text { Dentino: Jurnal } \\
\text { Kedokteran Gigi }\end{array}$ & 25274937 & $\begin{array}{l}\text { Fakultas } \\
\text { Kedokteran Gigi } \\
\text { Universitas } \\
\text { Lambung } \\
\text { Mangkurat }\end{array}$ & $\begin{array}{l}\text { Reakreditasi } \\
\text { Tetap di } \\
\text { Peringkat } 3 \text { mulai } \\
\text { Volume } 4 \text { Nomor } \\
2 \text { Tahun } 2019\end{array}$ \\
\hline & 28 & $\begin{array}{l}\text { Desimal: Jurnal } \\
\text { Matematika }\end{array}$ & 26139081 & $\begin{array}{l}\text { Prodi Pendidikan } \\
\text { Matamatika } \\
\text { Fakultas } \\
\text { Tarbiyah dan } \\
\text { Keguruan UIN } \\
\text { Raden Intan } \\
\text { Lampung }\end{array}$ & $\begin{array}{l}\text { Reakreditasi } \\
\text { Tetap di } \\
\text { Peringkat } 3 \text { mulai } \\
\text { Volume } 3 \text { Nomor } \\
1 \text { Tahun } 2020\end{array}$ \\
\hline & 29 & $\begin{array}{l}\text { Diglosia: Jurnal } \\
\text { Kajian Bahasa, } \\
\text { Sastra, dan } \\
\text { Pengajarannya }\end{array}$ & 26158655 & $\begin{array}{l}\text { Universitas } \\
\text { Mulawarman }\end{array}$ & $\begin{array}{l}\text { Reakreditasi Naik } \\
\text { Peringkat dari } \\
\text { Peringkat } 4 \text { ke } \\
\text { Peringkat } 3 \text { mulai } \\
\text { Volume } 3 \text { Nomor } \\
1 \text { Tahun } 2020\end{array}$ \\
\hline & 30 & $\begin{array}{l}\text { Dimas: Jurnal } \\
\text { Pemikiran Agama } \\
\text { untuk } \\
\text { Pemberdayaan }\end{array}$ & 25029428 & $\begin{array}{l}\text { LP2M UIN } \\
\text { Walisongo }\end{array}$ & $\begin{array}{l}\text { Reakreditasi Naik } \\
\text { Peringkat dari } \\
\text { Peringkat } 4 \text { ke } \\
\text { Peringkat } 3 \text { mulai } \\
\text { Volume } 19 \\
\text { Nomor } 2 \text { Tahun } \\
2019\end{array}$ \\
\hline & 31 & $\begin{array}{l}\text { Dinika Academic } \\
\text { Journal of Islamic } \\
\text { Studies }\end{array}$ & 25034227 & IAIN Surakarta & $\begin{array}{l}\text { Reakreditasi } \\
\text { Tetap di } \\
\text { Peringkat } 3 \text { mulai } \\
\text { Volume } 4 \text { Nomor } \\
3 \text { Tahun } 2019 \\
\end{array}$ \\
\hline & 32 & $\begin{array}{l}\text { Diponegoro } \\
\text { International } \\
\text { Journal of Business }\end{array}$ & 25804995 & $\begin{array}{l}\text { Universitas } \\
\text { Diponegoro }\end{array}$ & $\begin{array}{l}\text { Usulan Baru } \\
\text { mulai Volume } 1 \\
\text { Nomor } 1 \text { Tahun } \\
2018\end{array}$ \\
\hline
\end{tabular}

33. English ... 


\begin{tabular}{|c|c|c|c|c|c|}
\hline \begin{tabular}{|l|} 
Peringkat \\
\end{tabular} & No. & Nama Jurnal & E-ISSN & Penerbit & Keterangan \\
\hline & 33 & $\begin{array}{l}\text { English Franca: } \\
\text { Academic Journal of } \\
\text { English Language } \\
\text { and Education }\end{array}$ & 25803689 & $\begin{array}{l}\text { Institut Agama } \\
\text { Islam Negeri } \\
\text { (IAIN) Curup }\end{array}$ & $\begin{array}{l}\text { Reakreditasi } \\
\text { Tetap di } \\
\text { Peringkat } 3 \text { mulai } \\
\text { Volume } 3 \text { Nomor } \\
2 \text { Tahun } 2019\end{array}$ \\
\hline & 34 & $\begin{array}{l}\text { English Language } \\
\text { Teaching } \\
\text { Educational Journal }\end{array}$ & 26216485 & $\begin{array}{l}\text { Universitas } \\
\text { Ahmad Dahlan }\end{array}$ & $\begin{array}{l}\text { Usulan Baru } \\
\text { mulai Volume } 1 \\
\text { Nomor } 1 \text { Tahun } \\
2018\end{array}$ \\
\hline & 35 & $\begin{array}{l}\text { Fitofarmaka: Jurnal } \\
\text { Ilmiah Farmasi }\end{array}$ & $2622755 \mathrm{X}$ & $\begin{array}{l}\text { Universitas } \\
\text { Pakuan }\end{array}$ & $\begin{array}{l}\text { Usulan Baru } \\
\text { mulai Volume } 8 \\
\text { Nomor } 1 \text { Tahun } \\
2018\end{array}$ \\
\hline & 36 & $\begin{array}{l}\text { Food Science and } \\
\text { Technology Journal } \\
\text { (Foodscitech) }\end{array}$ & 26224127 & $\begin{array}{l}\text { Universitas Dr } \\
\text { Soetomo } \\
\text { Surabaya }\end{array}$ & $\begin{array}{l}\text { Usulan Baru } \\
\text { mulai Volume } 1 \\
\text { Nomor } 1 \text { Tahun } \\
2018\end{array}$ \\
\hline & 37 & $\begin{array}{l}\text { Gondang: Jurnal } \\
\text { Seni dan Budaya }\end{array}$ & 25990543 & $\begin{array}{l}\text { Universitas } \\
\text { Negeri Medan }\end{array}$ & $\begin{array}{l}\text { Reakreditasi Naik } \\
\text { Peringkat dari } \\
\text { Peringkat } 4 \text { ke } \\
\text { Peringkat } 3 \text { mulai } \\
\text { Volume } 3 \text { Nomor } \\
2 \text { Tahun } 2019\end{array}$ \\
\hline & 38 & $\begin{array}{l}\text { Harmoni Sosial: } \\
\text { Jurnal Pendidikan } \\
\text { IPS }\end{array}$ & 24607916 & $\begin{array}{l}\text { Himpunan } \\
\text { Sarjana } \\
\text { Pendidikan Ilmu- } \\
\text { Ilmu Sosial } \\
\text { Indonesia } \\
\text { (HISPISI) } \\
\text { bekerjasama } \\
\text { dengan Program } \\
\text { Studi Pendidikan } \\
\text { IPS Pascasarjana } \\
\text { Universitas } \\
\text { Negeri } \\
\text { Yogyakarta } \\
\end{array}$ & $\begin{array}{l}\text { Reakreditasi Naik } \\
\text { Peringkat dari } \\
\text { Peringkat } 4 \text { ke } \\
\text { Peringkat } 3 \text { mulai } \\
\text { Volume } 6 \text { Nomor } \\
2 \text { Tahun } 2019\end{array}$ \\
\hline & 39 & $\begin{array}{l}\text { Indonesian Journal } \\
\text { of Artificial } \\
\text { Intelligence and } \\
\text { Data Mining }\end{array}$ & 26146150 & $\begin{array}{l}\text { Universitas Islam } \\
\text { Negeri Sultan } \\
\text { Syarif Kasim } \\
\text { Riau }\end{array}$ & $\begin{array}{l}\text { Usulan Baru } \\
\text { mulai Volume } 1 \\
\text { Nomor } 1 \text { Tahun } \\
2018\end{array}$ \\
\hline & 40 & $\begin{array}{l}\text { Indonesian Journal } \\
\text { of Guidance and } \\
\text { Counseling: Theory } \\
\text { and Application }\end{array}$ & 25976133 & $\begin{array}{l}\text { Jurusan } \\
\text { Bimbingan dan } \\
\text { Konseling, } \\
\text { Fakultas Ilmu } \\
\text { Pendidikan, } \\
\text { Universitas } \\
\text { Negeri Semarang }\end{array}$ & $\begin{array}{l}\text { Reakreditasi } \\
\text { Tetap di } \\
\text { Peringkat } 3 \text { mulai } \\
\text { Volume } 8 \text { Nomor } \\
2 \text { Tahun } 2019\end{array}$ \\
\hline
\end{tabular}




\begin{tabular}{|c|c|c|c|c|c|}
\hline \begin{tabular}{|l|} 
Peringkat \\
\end{tabular} & No. & Nama Jurnal & E-ISSN & Penerbit & Keterangan \\
\hline & 41 & $\begin{array}{l}\text { Indonesian Journal } \\
\text { of Science and } \\
\text { Education }\end{array}$ & 25985205 & $\begin{array}{l}\text { Fakultas } \\
\text { Keguruan dan } \\
\text { Ilmu Pendidikan, } \\
\text { Universitas Tidar }\end{array}$ & $\begin{array}{l}\text { Reakreditasi } \\
\text { Tetap di } \\
\text { Peringkat } 3 \text { mulai } \\
\text { Volume } 3 \text { Nomor } \\
2 \text { Tahun } 2019 \\
\end{array}$ \\
\hline & 42 & $\begin{array}{l}\text { Indonesian Review } \\
\text { of Physics (IRiP) }\end{array}$ & 26212889 & $\begin{array}{l}\text { Universitas } \\
\text { Ahmad Dahlan }\end{array}$ & $\begin{array}{l}\text { Usulan Baru } \\
\text { mulai Volume } 1 \\
\text { Nomor } 1 \text { Tahun } \\
2018\end{array}$ \\
\hline & 43 & Infotekmesin & 26859858 & $\begin{array}{l}\text { P3M, Politeknik } \\
\text { Negeri Cilacap }\end{array}$ & $\begin{array}{l}\text { Reakreditasi Naik } \\
\text { Peringkat dari } \\
\text { Peringkat } 4 \text { ke } \\
\text { Peringkat } 3 \text { mulai } \\
\text { Volume } 11 \\
\text { Nomor } 1 \text { Tahun } \\
2020\end{array}$ \\
\hline & 44 & $\begin{array}{l}\text { International } \\
\text { Journal of Language } \\
\text { Teaching and } \\
\text { Education }\end{array}$ & 25982303 & $\begin{array}{l}\text { Magister Program } \\
\text { of English } \\
\text { Education } \\
\text { Department, } \\
\text { Universitas } \\
\text { Jambi }\end{array}$ & $\begin{array}{l}\text { Reakreditasi Naik } \\
\text { Peringkat dari } \\
\text { Peringkat } 4 \text { ke } \\
\text { Peringkat } 3 \text { mulai } \\
\text { Volume } 3 \text { Nomor } \\
2 \text { Tahun } 2019 \\
\end{array}$ \\
\hline & 45 & $\begin{array}{l}\text { International } \\
\text { Journal of Zakat } \\
\text { (IJAZ) }\end{array}$ & 25482335 & $\begin{array}{l}\text { Pusat Kajian } \\
\text { Strategis Badan } \\
\text { Amil Zakat } \\
\text { Nasional }\end{array}$ & $\begin{array}{l}\text { Usulan Baru } \\
\text { mulai Volume } 3 \\
\text { Nomor } 3 \text { Tahun } \\
2018\end{array}$ \\
\hline & 46 & $\begin{array}{l}\text { Istawa: Jurnal } \\
\text { Pendidikan Islam }\end{array}$ & 25410970 & $\begin{array}{l}\text { Postgraduate } \\
\text { Universitas } \\
\text { Muhammadiyah } \\
\text { Ponorogo }\end{array}$ & $\begin{array}{l}\text { Reakreditasi } \\
\text { Tetap di } \\
\text { Peringkat } 3 \text { mulai } \\
\text { Volume } 4 \text { Nomor } \\
2 \text { Tahun } 2019\end{array}$ \\
\hline & 47 & $\begin{array}{l}\text { JAK (Jurnal } \\
\text { Akuntansi): Kajian } \\
\text { Ilmiah Akuntansi }\end{array}$ & 25495968 & $\begin{array}{l}\text { Prodi Akuntansi } \\
\text { FEB Universitas } \\
\text { Serang Raya }\end{array}$ & $\begin{array}{l}\text { Reakreditasi Naik } \\
\text { Peringkat dari } \\
\text { Peringkat } 4 \text { ke } \\
\text { Peringkat } 3 \text { mulai } \\
\text { Volume } 7 \text { Nomor } \\
1 \text { Tahun } 2020\end{array}$ \\
\hline & 48 & $\begin{array}{l}\text { JAMP: Jurnal } \\
\text { Administrasi dan } \\
\text { Manajemen } \\
\text { Pendidikan }\end{array}$ & 26158574 & $\begin{array}{l}\text { Jurusan } \\
\text { Administrasi } \\
\text { Pendidikan } \\
\text { Fakultas Ilmu } \\
\text { Pendidikan } \\
\text { Universitas } \\
\text { Negeri Malang }\end{array}$ & $\begin{array}{l}\text { Usulan Baru } \\
\text { mulai Volume } 1 \\
\text { Nomor } 1 \text { Tahun } \\
2018\end{array}$ \\
\hline & 49 & $\begin{array}{l}\text { Jati: Jurnal } \\
\text { Akuntansi Terapan } \\
\text { Indonesia }\end{array}$ & 26150689 & $\begin{array}{l}\text { Universitas } \\
\text { Muhammadiyah } \\
\text { Yogyakarta }\end{array}$ & $\begin{array}{l}\text { Usulan Baru } \\
\text { mulai Volume } 1 \\
\text { Nomor } 1 \text { Tahun } \\
2018\end{array}$ \\
\hline
\end{tabular}




\begin{tabular}{|c|c|c|c|c|c|}
\hline \begin{tabular}{|l|} 
Peringkat \\
\end{tabular} & No. & Nama Jurnal & E-ISSN & Penerbit & Keterangan \\
\hline & 50 & $\begin{array}{l}\text { JIPI (Jurnal IPA dan } \\
\text { Pembelajaran IPA) }\end{array}$ & $2620553 X$ & $\begin{array}{l}\text { Universitas Syiah } \\
\text { Kuala }\end{array}$ & $\begin{array}{l}\text { Reakreditasi } \\
\text { Tetap di } \\
\text { Peringkat } 3 \text { mulai } \\
\text { Volume } 3 \text { Nomor } \\
2 \text { Tahun } 2019\end{array}$ \\
\hline & 51 & $\begin{array}{l}\text { JITeCS (Journal of } \\
\text { Information } \\
\text { Technology and } \\
\text { Computer Science) }\end{array}$ & 25409824 & $\begin{array}{l}\text { Fakultas Ilmu } \\
\text { Komputer, } \\
\text { Universitas } \\
\text { Brawijaya }\end{array}$ & $\begin{array}{l}\text { Reakreditasi Naik } \\
\text { Peringkat dari } \\
\text { Peringkat } 4 \text { ke } \\
\text { Peringkat } 3 \text { mulai } \\
\text { Volume } 4 \text { Nomor } \\
\text { 3 Tahun } 2019\end{array}$ \\
\hline & 52 & $\begin{array}{l}\text { JMIE (Journal of } \\
\text { Madrasah } \\
\text { Ibtidaiyah } \\
\text { Education) }\end{array}$ & 25802739 & $\begin{array}{l}\text { Perkumpulan } \\
\text { Dosen } \\
\text { Pendidikan Guru } \\
\text { Madrasah } \\
\text { Ibtidaiyah } \\
\text { se-Indonesia }\end{array}$ & $\begin{array}{l}\text { Reakreditasi Naik } \\
\text { Peringkat dari } \\
\text { Peringkat } 4 \text { ke } \\
\text { Peringkat } 3 \text { mulai } \\
\text { Volume } 3 \text { Nomor } \\
2 \text { Tahun } 2019\end{array}$ \\
\hline & 53 & $\begin{array}{l}\text { JMM (Jurnal } \\
\text { Masyarakat } \\
\text { Mandiri) }\end{array}$ & 26145758 & $\begin{array}{l}\text { Universitas } \\
\text { Muhammadiyah } \\
\text { Mataram }\end{array}$ & $\begin{array}{l}\text { Reakreditasi Naik } \\
\text { Peringkat dari } \\
\text { Peringkat } 4 \text { ke } \\
\text { Peringkat } 3 \text { mulai } \\
\text { Volume } 4 \text { Nomor } \\
1 \text { Tahun } 2020 \\
\end{array}$ \\
\hline & 54 & $\begin{array}{l}\text { JOMIS (Journal of } \\
\text { Midwifery Science) }\end{array}$ & 25797077 & $\begin{array}{l}\text { LPPM Universitas } \\
\text { Abdurrab }\end{array}$ & $\begin{array}{l}\text { Usulan Baru } \\
\text { mulai Volume } 3 \\
\text { Nomor } 1 \text { Tahun } \\
2019\end{array}$ \\
\hline & 55 & $\begin{array}{l}\text { Journal } \\
\text { Communication } \\
\text { Spectrum: Capturing } \\
\text { New Perspectives in } \\
\text { Communication } \\
\end{array}$ & 26226405 & $\begin{array}{l}\text { UB Press } \\
\text { Universitas } \\
\text { Bakrie }\end{array}$ & $\begin{array}{l}\text { Usulan Baru } \\
\text { mulai Volume } 8 \\
\text { Nomor } 1 \text { Tahun } \\
2018\end{array}$ \\
\hline & 56 & $\begin{array}{l}\text { Journal of } \\
\text { Indonesian Dental } \\
\text { Association }\end{array}$ & 26216175 & $\begin{array}{l}\text { Persatuan Dokter } \\
\text { Gigi Indonesia }\end{array}$ & $\begin{array}{l}\text { Usulan Baru } \\
\text { mulai Volume } 1 \\
\text { Nomor } 1 \text { Tahun } \\
2018\end{array}$ \\
\hline & 57 & $\begin{array}{l}\text { Journal of Applied } \\
\text { Food Technology }\end{array}$ & 26147076 & $\begin{array}{l}\text { Fakultas } \\
\text { Peternakan dan } \\
\text { Pertanian } \\
\text { Universitas } \\
\text { Diponegoro } \\
\text { bekerjasama } \\
\text { dengan } \\
\text { Indonesian Food } \\
\text { Technologists } \\
\end{array}$ & $\begin{array}{l}\text { Usulan Baru } \\
\text { mulai Volume } 5 \\
\text { Nomor } 1 \text { Tahun } \\
2018\end{array}$ \\
\hline & 58 & $\begin{array}{l}\text { Journal of } \\
\text { Community } \\
\text { Empowerment for } \\
\text { Health }\end{array}$ & 26550164 & $\begin{array}{l}\text { Universitas } \\
\text { Gadjah Mada }\end{array}$ & $\begin{array}{l}\text { Usulan Baru } \\
\text { mulai Volume } 1 \\
\text { Nomor } 1 \text { Tahun } \\
2018\end{array}$ \\
\hline
\end{tabular}




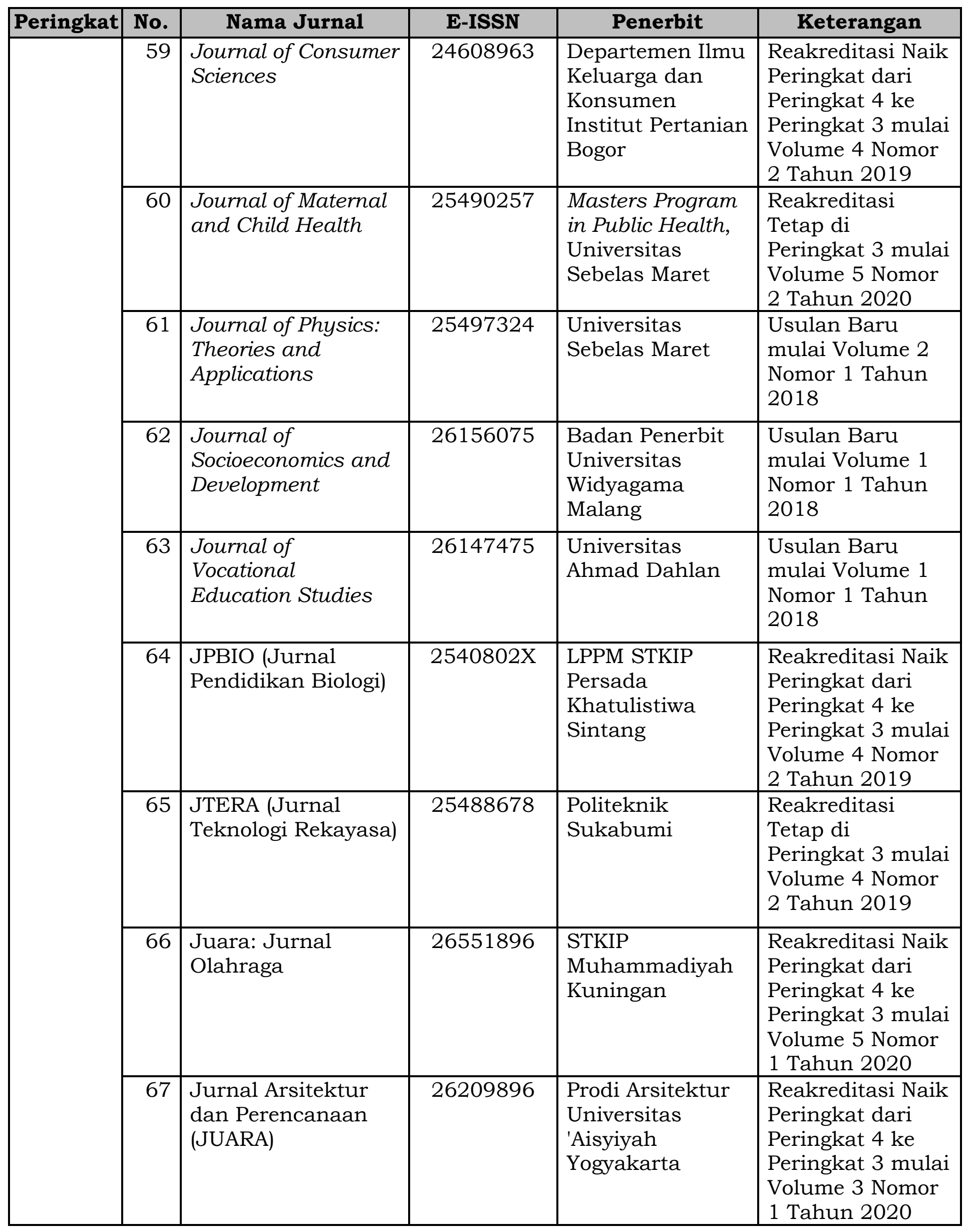

68. Jurnal ... 


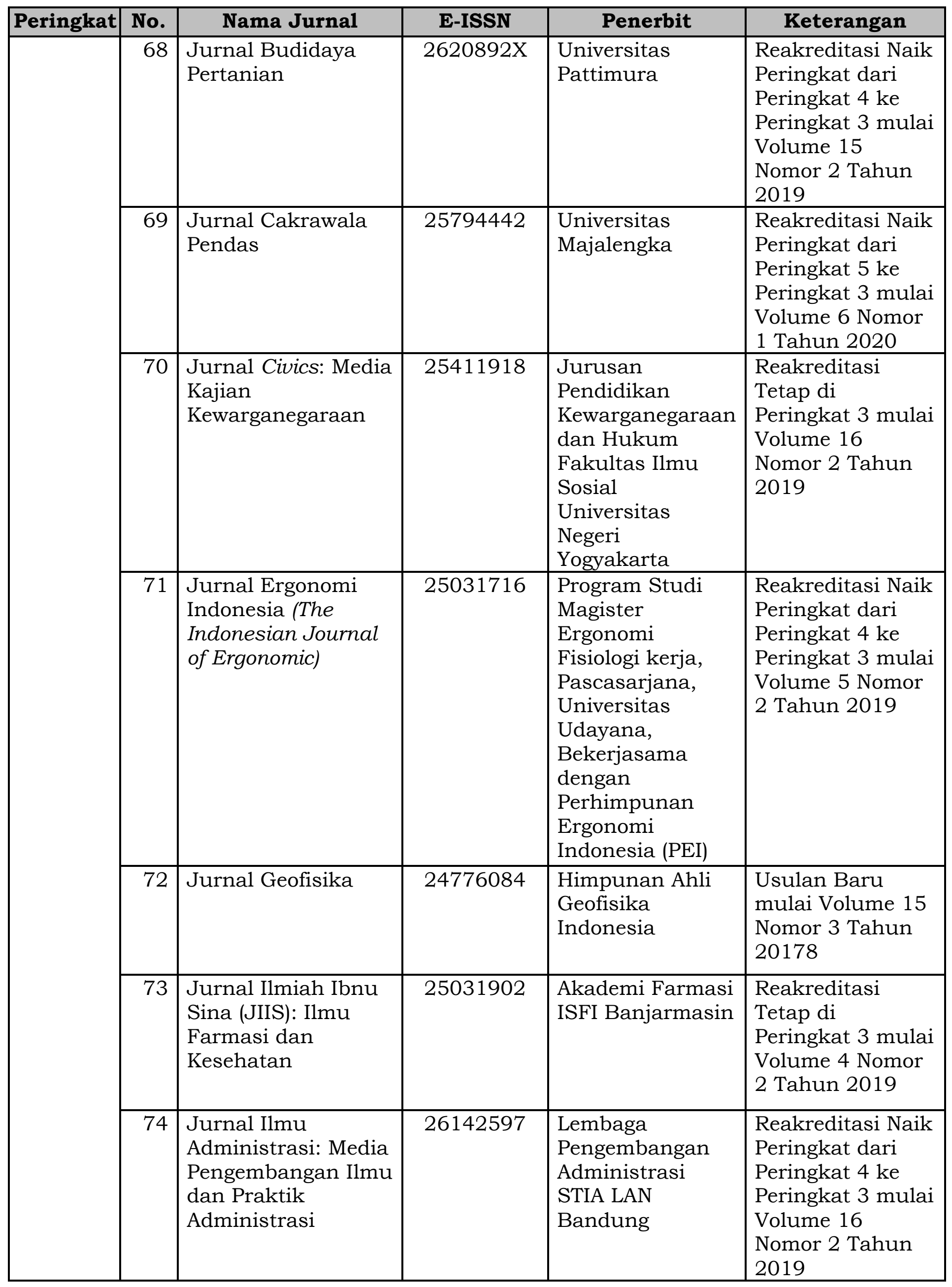




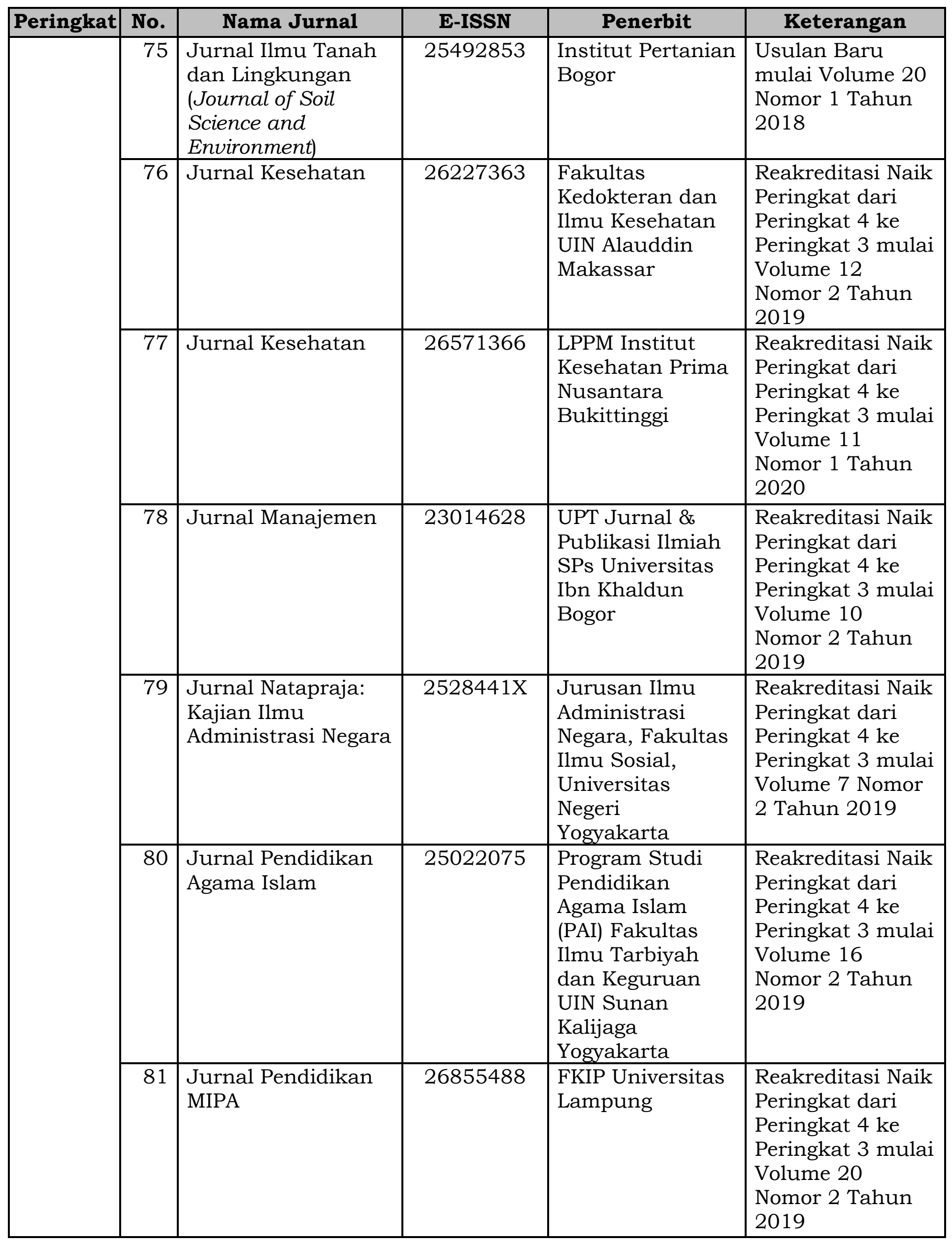

82. Jurnal ... 


\begin{tabular}{|c|c|c|c|c|c|}
\hline Peringkat & No. & Nama Jurnal & E-ISSN & Penerbit & Keterangan \\
\hline & 82 & $\begin{array}{l}\text { Jurnal Penelitan } \\
\text { Ekonomi dan Bisnis }\end{array}$ & 2460429 & $\begin{array}{l}\text { Fakultas } \\
\text { Ekonomi dan } \\
\text { Bisnis, } \\
\text { Universitas Dian } \\
\text { Nuswantoro }\end{array}$ & $\begin{array}{l}\text { Reakreditasi Naik } \\
\text { Peringkat dari } \\
\text { Peringkat } 4 \text { ke } \\
\text { Peringkat } 3 \\
\text { mulai Volume } 4 \\
\text { Nomor } 2 \text { Tahun } \\
2019\end{array}$ \\
\hline & 83 & $\begin{array}{l}\text { Jurnal Penelitian } \\
\text { Ilmu Pendidikan }\end{array}$ & 25415492 & $\begin{array}{l}\text { Fakultas Ilmu } \\
\text { Pendidikan } \\
\text { Universitas } \\
\text { Negeri } \\
\text { Yogyakarta }\end{array}$ & $\begin{array}{l}\text { Reakreditasi Naik } \\
\text { Peringkat dari } \\
\text { Peringkat } 4 \text { ke } \\
\text { Peringkat } 3 \\
\text { mulai Volume } 12 \\
\text { Nomor } 2 \text { Tahun } \\
2019 \\
\end{array}$ \\
\hline & 84 & Jurnal Promkes & 25409972 & $\begin{array}{l}\text { Fakultas } \\
\text { Kesehatan } \\
\text { Masyarakat } \\
\text { Universitas } \\
\text { Airlangga }\end{array}$ & $\begin{array}{l}\text { Reakreditasi Naik } \\
\text { Peringkat dari } \\
\text { Peringkat } 4 \text { ke } \\
\text { Peringkat } 3 \text { mulai } \\
\text { Volume } 7 \text { Nomor } \\
2 \text { Tahun } 2019\end{array}$ \\
\hline & 85 & $\begin{array}{l}\text { Jurnal } \\
\text { Psikohumanika }\end{array}$ & 23020660 & $\begin{array}{l}\text { Fakultas } \\
\text { Psikologi } \\
\text { Universitas Setia } \\
\text { Budi Surakarta }\end{array}$ & $\begin{array}{l}\text { Usulan Baru } \\
\text { mulai Volume } 10 \\
\text { Nomor } 1 \text { Tahun } \\
2018\end{array}$ \\
\hline & 86 & $\begin{array}{l}\text { Jurnal Psikologi } \\
\text { Pendidikan dan } \\
\text { Konseling: Jurnal } \\
\text { Kajian Psikologi } \\
\text { Pendidikan dan } \\
\text { Bimbingan } \\
\text { Konseling } \\
\end{array}$ & 24772518 & $\begin{array}{l}\text { Universitas } \\
\text { Negeri Makassar }\end{array}$ & $\begin{array}{l}\text { Reakreditasi } \\
\text { Tetap di } \\
\text { Peringkat } 3 \text { mulai } \\
\text { Volume } 5 \text { Nomor } \\
2 \text { Tahun } 2019\end{array}$ \\
\hline & 87 & $\begin{array}{l}\text { Jurnal Rekayasa } \\
\text { Sistem Industri }\end{array}$ & 23391499 & $\begin{array}{l}\text { Teknik Industri - } \\
\text { Universitas } \\
\text { Katolik } \\
\text { Parahyangan }\end{array}$ & $\begin{array}{l}\text { Reakreditasi Naik } \\
\text { Peringkat dari } \\
\text { Peringkat } 4 \text { ke } \\
\text { Peringkat } 3 \text { mulai } \\
\text { Volume } 8 \text { Nomor } \\
2 \text { Tahun } 2019\end{array}$ \\
\hline & 88 & $\begin{array}{l}\text { Jurnal Sistem dan } \\
\text { Manajemen Industri }\end{array}$ & 25802895 & $\begin{array}{l}\text { Universitas } \\
\text { Serang Raya }\end{array}$ & $\begin{array}{l}\text { Reakreditasi } \\
\text { Tetap di } \\
\text { Peringkat } 3 \text { mulai } \\
\text { Volume } 3 \text { Nomor } \\
2 \text { Tahun } 2019\end{array}$ \\
\hline & 89 & $\begin{array}{l}\text { Jurnal Tadris } \\
\text { Matematika }\end{array}$ & 26214008 & $\begin{array}{l}\text { Jurusan Tadris } \\
\text { Matematika, IAIN } \\
\text { Tulungagung }\end{array}$ & $\begin{array}{l}\text { Usulan Baru } \\
\text { mulai Volume } 1 \\
\text { Nomor } 1 \text { Tahun } \\
2018\end{array}$ \\
\hline & 90 & $\begin{array}{l}\text { Jurnal Tekno } \\
\text { Insentif }\end{array}$ & $2655089 X$ & $\begin{array}{l}\text { Lembaga } \\
\text { Layanan } \\
\text { Pendidikan } \\
\text { Tinggi Wilayah IV }\end{array}$ & $\begin{array}{l}\text { Usulan Baru } \\
\text { mulai Volume } 12 \\
\text { Nomor } 2 \text { Tahun } \\
2018\end{array}$ \\
\hline
\end{tabular}




\begin{tabular}{|c|c|c|c|c|c|}
\hline Peringkat & No. & Nama Jurnal & E-ISSN & Penerbit & Keterangan \\
\hline & 91 & $\begin{array}{l}\text { Jurnal Universitas } \\
\text { Kadiri Riset Teknik } \\
\text { Sipil }\end{array}$ & 25810855 & $\begin{array}{l}\text { Universitas } \\
\text { Kadiri }\end{array}$ & $\begin{array}{l}\text { Usulan Baru } \\
\text { mulai Volume } 2 \\
\text { Nomor } 1 \text { Tahun } \\
2018\end{array}$ \\
\hline & 92 & Komunikator & 25499246 & $\begin{array}{l}\text { Jurusan Ilmu } \\
\text { Komunikasi } \\
\text { Universitas } \\
\text { Muhammadiyah } \\
\text { Yogyakarta }\end{array}$ & $\begin{array}{l}\text { Reakreditasi } \\
\text { Tetap di } \\
\text { Peringkat } 3 \text { mulai } \\
\text { Volume } 11 \\
\text { Nomor } 2 \text { Tahun } \\
2019\end{array}$ \\
\hline & 93 & $\begin{array}{l}\text { Kontemplasi: Jurnal } \\
\text { Ke-Ushuluddinan }\end{array}$ & 25806866 & $\begin{array}{l}\text { Institut Agama } \\
\text { Islam Negeri } \\
\text { Tulungagung }\end{array}$ & $\begin{array}{l}\text { Usulan Baru } \\
\text { mulai Volume } 6 \\
\text { Nomor } 1 \text { Tahun } \\
2018\end{array}$ \\
\hline & 94 & Konversi & 25413481 & $\begin{array}{l}\text { Program Studi } \\
\text { Teknik Kimia } \\
\text { Fakultas Teknik } \\
\text { Universitas } \\
\text { Lambung } \\
\text { Mangkurat }\end{array}$ & $\begin{array}{l}\text { Reakreditasi Naik } \\
\text { Peringkat dari } \\
\text { Peringkat } 4 \text { ke } \\
\text { Peringkat } 3 \text { mulai } \\
\text { Volume } 8 \text { Nomor } \\
2 \text { Tahun } 2019\end{array}$ \\
\hline & 95 & $\begin{array}{l}\text { Lensa: Kajian } \\
\text { Kebahasaan, } \\
\text { Kesusastraan, dan } \\
\text { Budaya }\end{array}$ & $2503328 \mathrm{X}$ & $\begin{array}{l}\text { Fakultas Bahasa } \\
\text { dan Budaya } \\
\text { Asing (FBBA), } \\
\text { Universitas } \\
\text { Muhammadiyah } \\
\text { Semarang }\end{array}$ & $\begin{array}{l}\text { Reakreditasi } \\
\text { Tetap di } \\
\text { Peringkat } 3 \text { mulai } \\
\text { Volume } 9 \text { Nomor } \\
2 \text { Tahun } 2019\end{array}$ \\
\hline & 96 & Lentera Hukum & 26213710 & $\begin{array}{l}\text { Universitas } \\
\text { Jember }\end{array}$ & $\begin{array}{l}\text { Reakreditasi } \\
\text { Tetap di } \\
\text { Peringkat } 3 \text { mulai } \\
\text { Volume } 6 \text { Nomor } \\
3 \text { Tahun } 2019\end{array}$ \\
\hline & 97 & $\begin{array}{l}\text { Lentera Pustaka: } \\
\text { Jurnal Kajian Ilmu } \\
\text { Perpustakaan, } \\
\text { Informasi dan } \\
\text { Kearsipan }\end{array}$ & 25409638 & $\begin{array}{l}\text { Program Studi } \\
\text { Ilmu } \\
\text { Perpustakaan } \\
\text { Fakultas Ilmu } \\
\text { Budaya } \\
\text { Universitas } \\
\text { Diponegoro }\end{array}$ & $\begin{array}{l}\text { Reakreditasi } \\
\text { Tetap di } \\
\text { Peringkat } 3 \text { mulai } \\
\text { Volume } 5 \text { Nomor } \\
2 \text { Tahun } 2019\end{array}$ \\
\hline & 98 & $\begin{array}{l}\text { LINGUA: Jurnal } \\
\text { Bahasa, Sastra, dan } \\
\text { Pengajarannya }\end{array}$ & $2442238 X$ & $\begin{array}{l}\text { Center of } \\
\text { Language and } \\
\text { Cultural Studies }\end{array}$ & $\begin{array}{l}\text { Reakreditasi } \\
\text { Tetap di } \\
\text { Peringkat } 3 \text { mulai } \\
\text { Volume } 15 \\
\text { Nomor } 2 \text { Tahun } \\
2018\end{array}$ \\
\hline & 99 & $\begin{array}{l}\text { Media Keperawatan } \\
\text { Indonesia }\end{array}$ & 26151669 & $\begin{array}{l}\text { LPPM Universitas } \\
\text { Muhammadiyah } \\
\text { Semarang }\end{array}$ & $\begin{array}{l}\text { Reakreditasi Naik } \\
\text { Peringkat dari } \\
\text { Peringkat } 4 \text { ke } \\
\text { Peringkat } 3 \text { mulai }\end{array}$ \\
\hline
\end{tabular}




\begin{tabular}{|c|c|c|c|c|c|}
\hline Peringkat & No. & Nama Jurnal & E-ISSN & Penerbit & Keterangan \\
\hline & & & & & $\begin{array}{l}\text { Volume } 3 \text { Nomor } \\
1 \text { Tahun } 2020\end{array}$ \\
\hline & 100 & $\begin{array}{l}\text { Metathesis: Journal } \\
\text { of English } \\
\text { Language, Literature } \\
\text { and Teaching }\end{array}$ & 25802720 & $\begin{array}{l}\text { Fakultas } \\
\text { Keguruan dan } \\
\text { Ilmu Pendidikan } \\
\text { Universitas Tidar }\end{array}$ & $\begin{array}{l}\text { Reakreditasi Naik } \\
\text { Peringkat dari } \\
\text { Peringkat } 4 \text { ke } \\
\text { Peringkat } 3 \text { mulai } \\
\text { Volume } 3 \text { Nomor } \\
2 \text { Tahun } 2019\end{array}$ \\
\hline & 101 & Muslim Heritage & 25025341 & $\begin{array}{l}\text { Institusi Agama } \\
\text { Islam Negeri } \\
\text { Ponorogo }\end{array}$ & $\begin{array}{l}\text { Reakreditasi Naik } \\
\text { Peringkat dari } \\
\text { Peringkat } 4 \text { ke } \\
\text { Peringkat } 3 \text { mulai } \\
\text { Volume } 4 \text { Nomor } \\
2 \text { Tahun } 2019\end{array}$ \\
\hline & 102 & $\begin{array}{l}\text { Nazhruna: Jurnal } \\
\text { Pendidikan Islam }\end{array}$ & 26148013 & $\begin{array}{l}\text { Program Studi } \\
\text { Pendidikan Islam } \\
\text { Institut } \\
\text { Pesantren KH } \\
\text { Abdul Chalim } \\
\text { Pacet Mojokerto }\end{array}$ & $\begin{array}{l}\text { Reakreditasi } \\
\text { Tetap di } \\
\text { Peringkat } 3 \text { mulai } \\
\text { Volume } 4 \text { Nomor } \\
1 \text { Tahun } 2020\end{array}$ \\
\hline & 103 & $\begin{array}{l}\text { NOBEL: Journal of } \\
\text { Literature and } \\
\text { Language Teaching }\end{array}$ & 25492470 & $\begin{array}{l}\text { English } \\
\text { Department, } \\
\text { Faculty of Arts } \\
\text { and Humanities, } \\
\text { UIN Sunan } \\
\text { Ampel Surabaya }\end{array}$ & $\begin{array}{l}\text { Reakreditasi } \\
\text { Tetap di } \\
\text { Peringkat } 3 \text { mulai } \\
\text { Volume } 10 \\
\text { Nomor } 2 \text { Tahun } \\
2019\end{array}$ \\
\hline & 104 & $\begin{array}{l}\text { Nurse and Health: } \\
\text { Jurnal Keperawatan }\end{array}$ & 26232448 & $\begin{array}{l}\text { LPPM Akademi } \\
\text { Keperawatan } \\
\text { Kerta Cendekia } \\
\text { Sidoarjo }\end{array}$ & $\begin{array}{l}\text { Reakreditasi Naik } \\
\text { Peringkat dari } \\
\text { Peringkat } 4 \text { ke } \\
\text { Peringkat } 3 \text { mulai } \\
\text { Volume } 8 \text { Nomor } \\
2 \text { Tahun } 2019\end{array}$ \\
\hline & 105 & $\begin{array}{l}\text { Organum: Jurnal } \\
\text { Saintifik } \\
\text { Manajemen dan } \\
\text { Akuntansi }\end{array}$ & 26208164 & $\begin{array}{l}\text { Universitas } \\
\text { Winaya Mukti }\end{array}$ & $\begin{array}{l}\text { Usulan Baru } \\
\text { mulai Volume } 1 \\
\text { Nomor } 1 \text { Tahun } \\
2018\end{array}$ \\
\hline & 106 & PCD Journal & 20850441 & $\begin{array}{l}\text { Research Center } \\
\text { for Politics and } \\
\text { Government } \\
\text { (PolGov) } \\
\text { Universitas } \\
\text { Gadjah Mada }\end{array}$ & $\begin{array}{l}\text { Reakreditasi } \\
\text { Tetap di } \\
\text { Peringkat } 3 \text { mulai } \\
\text { Volume } 7 \text { Nomor } \\
2 \text { Tahun } 2019\end{array}$ \\
\hline
\end{tabular}




\begin{tabular}{|c|c|c|c|c|c|}
\hline \begin{tabular}{|l|} 
Peringkat \\
\end{tabular} & No. & Nama Jurnal & E-ISSN & Penerbit & Keterangan \\
\hline & 107 & Perspektif & 26849305 & $\begin{array}{l}\text { Universitas } \\
\text { Medan Area }\end{array}$ & $\begin{array}{l}\text { Reakreditasi Naik } \\
\text { Peringkat dari } \\
\text { Peringkat } 4 \text { ke } \\
\text { Peringkat } 3 \text { mulai } \\
\text { Volume } 9 \text { Nomor } \\
1 \text { Tahun } 2020\end{array}$ \\
\hline & 108 & $\begin{array}{l}\text { Pilar Nusa Mandiri: } \\
\text { Journal of } \\
\text { Computing and } \\
\text { Information System }\end{array}$ & 25276514 & $\begin{array}{l}\text { LPPM STMIK } \\
\text { Nusa Mandiri } \\
\text { Jakarta }\end{array}$ & $\begin{array}{l}\text { Reakreditasi } \\
\text { Tetap di } \\
\text { Peringkat } 3 \text { mulai } \\
\text { Volume } 15 \\
\text { Nomor } 2 \text { Tahun } \\
2019\end{array}$ \\
\hline & 109 & $\begin{array}{l}\text { Prima: Jurnal } \\
\text { Pendidikan } \\
\text { Matematika }\end{array}$ & 25802216 & $\begin{array}{l}\text { FKIP Universitas } \\
\text { Muhammadiyah } \\
\text { Tangerang }\end{array}$ & $\begin{array}{l}\text { Reakreditasi Naik } \\
\text { Peringkat dari } \\
\text { Peringkat } 4 \text { ke } \\
\text { Peringkat } 3 \text { mulai } \\
\text { Volume } 4 \text { Nomor } \\
1 \text { Tahun } 2020\end{array}$ \\
\hline & 110 & $\begin{array}{l}\text { Prisma Sains: } \\
\text { Jurnal Pengkajian } \\
\text { Ilmu dan } \\
\text { Pembelajaran } \\
\text { Matematika dan IPA } \\
\text { IKIP Mataram }\end{array}$ & 25407899 & $\begin{array}{l}\text { Fakultas } \\
\text { Pendidikan } \\
\text { Matematika dan } \\
\text { IPA IKIP Mataram }\end{array}$ & $\begin{array}{l}\text { Reakreditasi } \\
\text { Tetap di } \\
\text { Peringkat } 3 \text { mulai } \\
\text { Volume } 7 \text { Nomor } \\
2 \text { Tahun } 2019\end{array}$ \\
\hline & 111 & Refleksi & 27146103 & $\begin{array}{l}\text { Fakultas } \\
\text { Ushuluddin UIN } \\
\text { Syarif } \\
\text { Hidayatullah } \\
\text { Jakarta }\end{array}$ & $\begin{array}{l}\text { Usulan Baru } \\
\text { mulai Volume } 17 \\
\text { Nomor } 1 \text { Tahun } \\
2018\end{array}$ \\
\hline & 112 & $\begin{array}{l}\text { Research: Computer, } \\
\text { Information System } \\
\& \text { Technology } \\
\text { Management }\end{array}$ & 26157357 & $\begin{array}{l}\text { Universitas PGRI } \\
\text { Madiun }\end{array}$ & $\begin{array}{l}\text { Usulan Baru } \\
\text { mulai Volume } 1 \\
\text { Nomor } 1 \text { Tahun } \\
2018\end{array}$ \\
\hline & 113 & $\begin{array}{l}\text { Riwayah: Jurnal } \\
\text { Studi Hadis }\end{array}$ & 25028839 & $\begin{array}{l}\text { Program Studi } \\
\text { Ilmu Hadis, } \\
\text { Jurusan } \\
\text { Ushuluddin } \\
\text { Sekolah Tinggi } \\
\text { Agama Islam } \\
\text { Negeri Kudus }\end{array}$ & $\begin{array}{l}\text { Reakreditasi Naik } \\
\text { Peringkat dari } \\
\text { Peringkat } 5 \text { ke } \\
\text { Peringkat } 3 \text { mulai } \\
\text { Volume } 5 \text { Nomor } \\
2 \text { Tahun } 2019\end{array}$ \\
\hline & 114 & $\begin{array}{l}\text { Science and } \\
\text { Technology } \\
\text { Indonesia }\end{array}$ & 25804391 & $\begin{array}{l}\text { Jurusan Kimia } \\
\text { FMIPA } \\
\text { Universitas } \\
\text { Sriwijaya }\end{array}$ & $\begin{array}{l}\text { Reakreditasi } \\
\text { Tetap di } \\
\text { Peringkat } 3 \text { mulai } \\
\text { Volume } 5 \text { Nomor } \\
1 \text { Tahun } 2020\end{array}$ \\
\hline
\end{tabular}




\begin{tabular}{|c|c|c|c|c|c|}
\hline \multirow[t]{9}{*}{ Peringkat } & No. & Nama Jurnal & E-ISSN & Penerbit & Keterangan \\
\hline & 115 & $\begin{array}{l}\text { Scientiae Educatia: } \\
\text { Jurnal Pendidikan } \\
\text { Sains }\end{array}$ & 25277596 & $\begin{array}{l}\text { Tadris Biologi } \\
\text { IAIN Syekh } \\
\text { Nurjati Cirebon } \\
\text { bekerjasama } \\
\text { dengan PPII } \\
\text { (Perhimpunan } \\
\text { Pendidik IPA } \\
\text { Indonesia) }\end{array}$ & $\begin{array}{l}\text { Reakreditasi } \\
\text { Tetap di } \\
\text { Peringkat } 3 \text { mulai } \\
\text { Volume } 8 \text { Nomor } \\
2 \text { Tahun } 2019\end{array}$ \\
\hline & 116 & Simulacra & 26568721 & $\begin{array}{l}\text { Universitas } \\
\text { Trunojoyo } \\
\text { Madura }\end{array}$ & $\begin{array}{l}\text { Usulan Baru } \\
\text { mulai Volume } 1 \\
\text { Nomor } 1 \text { Tahun } \\
2018\end{array}$ \\
\hline & 117 & $\begin{array}{l}\text { Sosioglobal: Jurnal } \\
\text { Pemikiran dan } \\
\text { Penelitian Sosiologi }\end{array}$ & 25484559 & $\begin{array}{l}\text { Departemen } \\
\text { Sosiologi, } \\
\text { Fakultas Ilmu } \\
\text { Sosial dan Ilmu } \\
\text { Politik, } \\
\text { Universitas } \\
\text { Padjadjaran } \\
\end{array}$ & $\begin{array}{l}\text { Reakreditasi Naik } \\
\text { Peringkat dari } \\
\text { Peringkat } 6 \text { ke } \\
\text { Peringkat } 3 \text { mulai } \\
\text { Volume } 4 \text { Nomor } \\
1 \text { Tahun } 2019\end{array}$ \\
\hline & 118 & $\begin{array}{l}\text { Tadbir: Jurnal Studi } \\
\text { Manajemen } \\
\text { Pendidikan }\end{array}$ & 25805037 & $\begin{array}{l}\text { Institut Agama } \\
\text { Islam Negeri } \\
\text { (IAIN) Curup }\end{array}$ & $\begin{array}{l}\text { Reakreditasi } \\
\text { Tetap di } \\
\text { Peringkat } 3 \text { mulai } \\
\text { Volume } 3 \text { Nomor } \\
2 \text { Tahun } 2019\end{array}$ \\
\hline & 119 & $\begin{array}{l}\text { Ta'dib: Jurnal } \\
\text { Pendidikan Islam }\end{array}$ & 25285092 & $\begin{array}{l}\text { Fakultas } \\
\text { Tarbiyah dan } \\
\text { Keguruan } \\
\text { Universitas Islam } \\
\text { Bandung dan } \\
\text { Asosiasi Dosen } \\
\text { Pendidikan } \\
\text { Agama Islam } \\
\text { Indonesia } \\
\text { (ADPISI) }\end{array}$ & $\begin{array}{l}\text { Usulan Baru } \\
\text { mulai Volume } 7 \\
\text { Nomor } 1 \text { Tahun } \\
2018\end{array}$ \\
\hline & 120 & $\begin{array}{l}\text { The Indonesian } \\
\text { Journal of } \\
\text { Occupational Safety } \\
\text { and Health }\end{array}$ & 25407872 & $\begin{array}{l}\text { Fakultas } \\
\text { Kesehatan } \\
\text { Masyarakat } \\
\text { Universitas } \\
\text { Airlangga }\end{array}$ & $\begin{array}{l}\text { Reakreditasi Naik } \\
\text { Peringkat dari } \\
\text { Peringkat } 4 \text { ke } \\
\text { Peringkat } 3 \text { mulai } \\
\text { Volume } 8 \text { Nomor } \\
\text { 3 Tahun } 2019 \\
\end{array}$ \\
\hline & 121 & $\begin{array}{l}\text { Veritas: Jurnal } \\
\text { Teologi dan } \\
\text { Pelayanan }\end{array}$ & 26849194 & $\begin{array}{l}\text { Sekolah Tinggi } \\
\text { Teologi SAAT }\end{array}$ & $\begin{array}{l}\text { Reakreditasi } \\
\text { Tetap di } \\
\text { Peringkat } 3 \text { mulai } \\
\text { Volume } 18 \\
\text { Nomor } 2 \text { Tahun } \\
2019\end{array}$ \\
\hline & 122 & $\begin{array}{l}\text { Volksgeist: Jurnal } \\
\text { Ilmu Hukum dan } \\
\text { Konstitusi }\end{array}$ & 26155648 & $\begin{array}{l}\text { Fakultas Syariah } \\
\text { IAIN Purwokerto }\end{array}$ & $\begin{array}{l}\text { Usulan Baru } \\
\text { mulai Volume } 1 \\
\text { Nomor } 1 \text { Tahun } \\
2018\end{array}$ \\
\hline
\end{tabular}




\begin{tabular}{|c|c|c|c|c|c|}
\hline Peringkat & No. & Nama Jurnal & E-ISSN & Penerbit & Keterangan \\
\hline & 123 & Warta LPM & 25495631 & $\begin{array}{l}\text { Lembaga } \\
\text { Penelitian dan } \\
\text { Pengabdian } \\
\text { Masyarakat } \\
\text { Universitas } \\
\text { Muhammadiyah } \\
\text { Surakarta } \\
\end{array}$ & $\begin{array}{l}\text { Reakreditasi Naik } \\
\text { Peringkat dari } \\
\text { Peringkat } 5 \text { ke } \\
\text { Peringkat } 3 \text { mulai } \\
\text { Volume } 23 \\
\text { Nomor } 1 \text { Tahun } \\
2020\end{array}$ \\
\hline \multirow[t]{8}{*}{4} & 1 & Abdimas Dewantara & 26158782 & $\begin{array}{l}\text { Universitas } \\
\text { sarjanawiyata } \\
\text { Tamansiswa }\end{array}$ & $\begin{array}{l}\text { Usulan Baru } \\
\text { mulai Volume } 1 \\
\text { Nomor } 1 \text { Tahun } \\
2018\end{array}$ \\
\hline & 2 & $\begin{array}{l}\text { Administratio: } \\
\text { Jurnal Ilmiah } \\
\text { Administrasi Publik } \\
\text { dan Pembangunan }\end{array}$ & 25486977 & $\begin{array}{l}\text { Jurusan Ilmu } \\
\text { Administrasi } \\
\text { Publik Fakultas } \\
\text { Ilmu Sosial dan } \\
\text { Ilmu Politik } \\
\text { Universitas } \\
\text { Lampung dan } \\
\text { Perhimpunan } \\
\text { Sarjana } \\
\text { Administrasi } \\
\text { Indonesia }\end{array}$ & $\begin{array}{l}\text { Reakreditasi Naik } \\
\text { Peringkat dari } \\
\text { Peringkat } 6 \mathrm{ke} \\
\text { Peringkat } 4 \text { mulai } \\
\text { Volume } 9 \text { Nomor } \\
1 \text { Tahun } 2018\end{array}$ \\
\hline & 3 & $\begin{array}{l}\text { Agrosains: Jurnal } \\
\text { Penelitian Agronomi }\end{array}$ & 26557339 & $\begin{array}{l}\text { Universitas } \\
\text { Sebelas Maret }\end{array}$ & $\begin{array}{l}\text { Usulan Baru } \\
\text { mulai Volume } 20 \\
\text { Nomor } 1 \text { Tahun } \\
2018\end{array}$ \\
\hline & 4 & $\begin{array}{l}\text { Al Fikra: Jurnal } \\
\text { Ilmiah Keislaman }\end{array}$ & 25027263 & $\begin{array}{l}\text { Universitas Islam } \\
\text { Negri Sultan } \\
\text { Syarif Kasim } \\
\text { Riau }\end{array}$ & $\begin{array}{l}\text { Usulan Baru } \\
\text { mulai Volume } 17 \\
\text { Nomor } 1 \text { Tahun } \\
2018\end{array}$ \\
\hline & 5 & $\begin{array}{l}\text { Al-Adabiya: Jurnal } \\
\text { Kebudayaan dan } \\
\text { Keagamaan }\end{array}$ & 25409204 & $\begin{array}{l}\text { IAI Sunan Giri } \\
\text { Ponorogo }\end{array}$ & $\begin{array}{l}\text { Usulan Baru } \\
\text { mulai Volume } 13 \\
\text { Nomor } 1 \text { Tahun } \\
2018\end{array}$ \\
\hline & 6 & $\begin{array}{l}\text { Al-Adl: Jurnal } \\
\text { Hukum }\end{array}$ & 24770124 & $\begin{array}{l}\text { Universitas Islam } \\
\text { Kalimantan } \\
\text { Muhammad } \\
\text { Aryad Al-Banjari }\end{array}$ & $\begin{array}{l}\text { Reakreditasi Naik } \\
\text { Peringkat dari } \\
\text { Peringkat } 5 \text { ke } \\
\text { Peringkat } 4 \text { mulai } \\
\text { Volume } 12 \\
\text { Nomor } 1 \text { Tahun } \\
2020\end{array}$ \\
\hline & 7 & $\begin{array}{l}\text { Al-Adzka: Jurnal } \\
\text { Ilmiah Pendidikan } \\
\text { Guru Madrasah } \\
\text { Ibtidaiyah }\end{array}$ & $2597937 X$ & $\begin{array}{l}\text { Jurusan PGMI } \\
\text { Fakultas } \\
\text { Tarbiyah dan } \\
\text { Keguruan UIN } \\
\text { Antasari } \\
\text { Banjarmasin }\end{array}$ & $\begin{array}{l}\text { Usulan Baru } \\
\text { mulai Volume } 8 \\
\text { Nomor } 1 \text { Tahun } \\
2018\end{array}$ \\
\hline & 8 & $\begin{array}{l}\text { Al-Bukhari: Jurnal } \\
\text { Ilmu Hadis }\end{array}$ & 26213559 & $\begin{array}{l}\text { Institut Agama } \\
\text { Islam Negeri } \\
\text { Zawiyah Cot Kala } \\
\text { Langsa }\end{array}$ & $\begin{array}{l}\text { Usulan Baru } \\
\text { mulai Volume } 1 \\
\text { Nomor } 1 \text { Tahun } \\
2018\end{array}$ \\
\hline
\end{tabular}




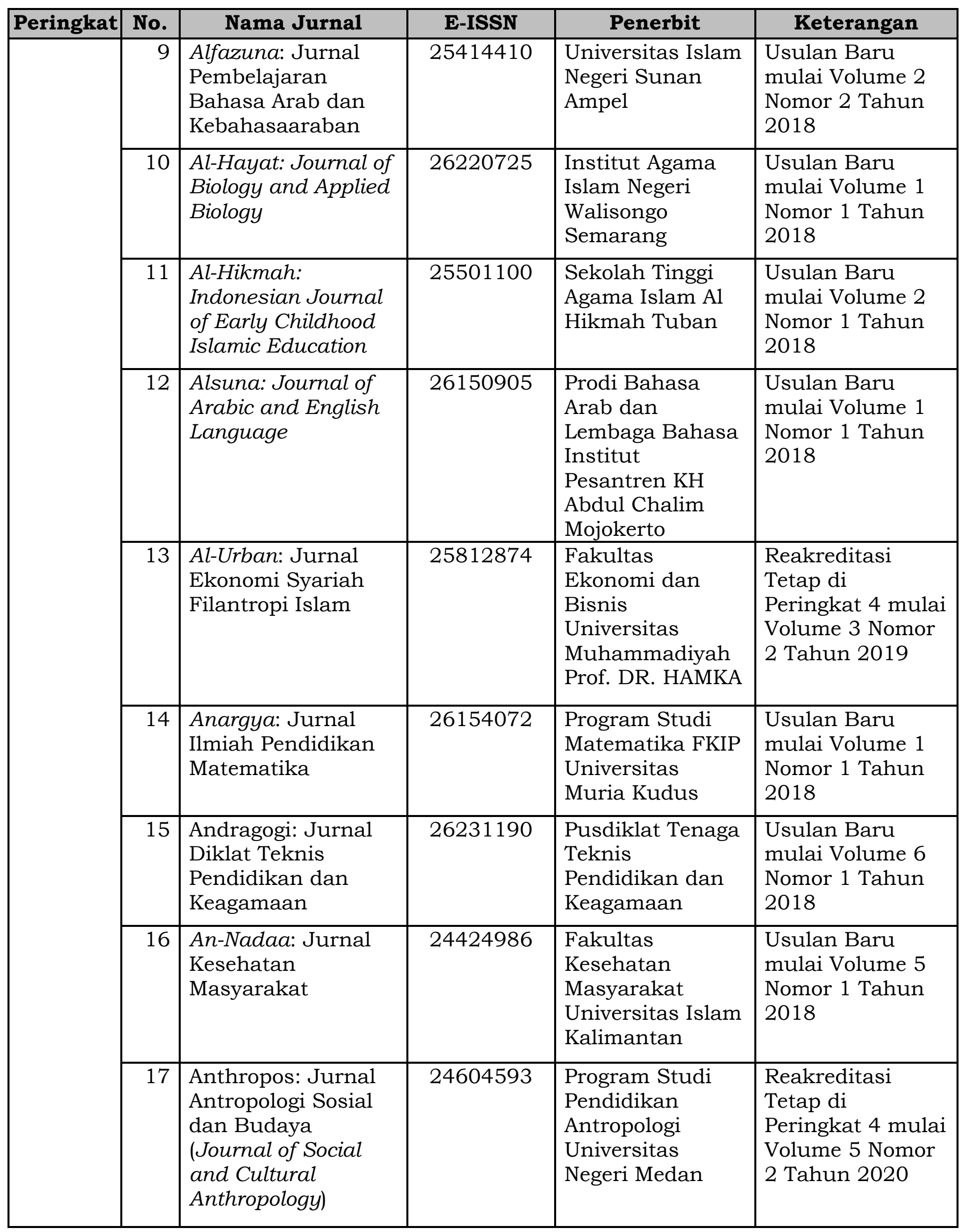

18. Astonjadro ... 


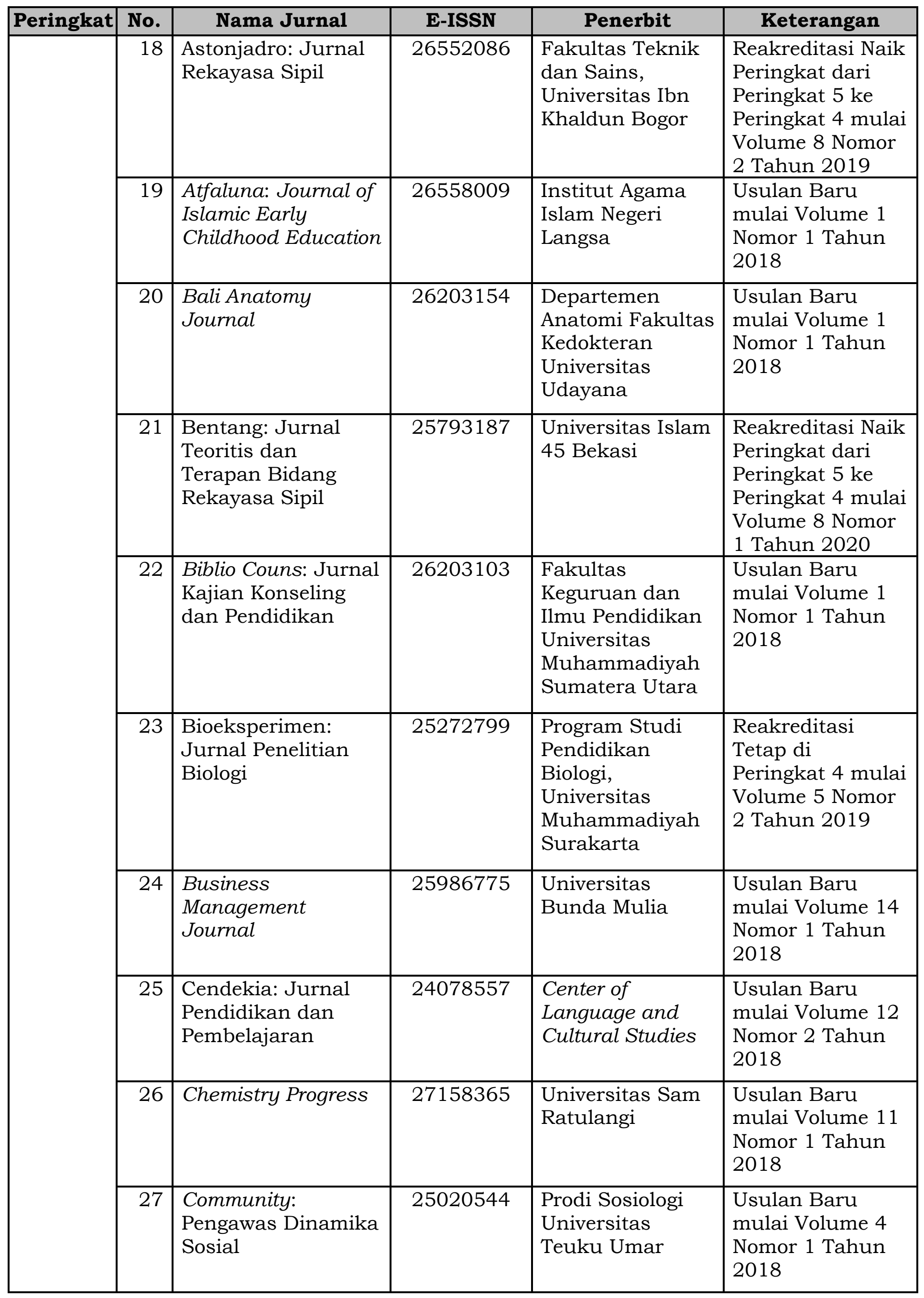




\begin{tabular}{|c|c|c|c|c|c|}
\hline Peringkat & No. & Nama Jurnal & E-ISSN & Penerbit & Keterangan \\
\hline & 28 & $\begin{array}{l}\text { Compton: Jurnal } \\
\text { Ilmiah Pendidikan } \\
\text { Fisika }\end{array}$ & 25795252 & $\begin{array}{l}\text { Prodi Pendidikan } \\
\text { Fisika, FKIP, } \\
\text { Universitas } \\
\text { Sarjanawiyata } \\
\text { Tamansiswa }\end{array}$ & $\begin{array}{l}\text { Reakreditasi Naik } \\
\text { Peringkat dari } \\
\text { Peringkat } 5 \text { ke } \\
\text { Peringkat } 4 \text { mulai } \\
\text { Volume } 6 \text { Nomor } \\
2 \text { Tahun } 2019\end{array}$ \\
\hline & 29 & $\begin{array}{l}\text { Cyberspace: Jurnal } \\
\text { Pendidikan } \\
\text { Teknologi Informasi }\end{array}$ & 25979671 & $\begin{array}{l}\text { Pusat Penelitian } \\
\text { dan Penerbitan } \\
\text { Lembaga } \\
\text { Penelitian dan } \\
\text { Pengabdian } \\
\text { kepada } \\
\text { Masyarakat dan } \\
\text { Pendidikan } \\
\text { Teknologi } \\
\text { Informasi UIN Ar- } \\
\text { Raniry }\end{array}$ & $\begin{array}{l}\text { Usulan Baru } \\
\text { mulai Volume } 2 \\
\text { Nomor } 1 \text { Tahun } \\
2018\end{array}$ \\
\hline & 30 & $\begin{array}{l}\text { De Fermat: Jurnal } \\
\text { Pendidikan } \\
\text { Matematika }\end{array}$ & 26217309 & $\begin{array}{l}\text { Universitas } \\
\text { Balikpapan }\end{array}$ & $\begin{array}{l}\text { Usulan Baru } \\
\text { mulai Volume } 1 \\
\text { Nomor } 1 \text { Tahun } \\
2018\end{array}$ \\
\hline & 31 & $\begin{array}{l}\text { Diakom: Jurnal } \\
\text { Media dan } \\
\text { Komunikasi }\end{array}$ & 26231212 & $\begin{array}{l}\text { Kementerian } \\
\text { Komunikasi dan } \\
\text { Informatika }\end{array}$ & $\begin{array}{l}\text { Usulan Baru } \\
\text { mulai Volume } 1 \\
\text { Nomor } 1 \text { Tahun } \\
2018\end{array}$ \\
\hline & 32 & Diksi & 25796399 & $\begin{array}{l}\text { Fakultas Bahasa } \\
\text { dan Seni } \\
\text { Universitas } \\
\text { Negeri } \\
\text { Yogyakarta }\end{array}$ & $\begin{array}{l}\text { Usulan Baru } \\
\text { mulai Volume } 26 \\
\text { Nomor } 1 \text { Tahun } \\
2018\end{array}$ \\
\hline & 33 & $\begin{array}{l}\text { Dinamika } \\
\text { Kesehatan: Jurnal } \\
\text { Kebidanan dan } \\
\text { Keperawatan }\end{array}$ & 25494058 & $\begin{array}{l}\text { LPPM Universitas } \\
\text { Sari Mulia }\end{array}$ & $\begin{array}{l}\text { Reakreditasi Naik } \\
\text { Peringkat dari } \\
\text { Peringkat } 5 \mathrm{ke} \\
\text { Peringkat } 4 \text { mulai } \\
\text { Volume } 10 \\
\text { Nomor } 2 \text { Tahun } \\
2019\end{array}$ \\
\hline & 34 & $\begin{array}{l}\text { e-Journal Ekonomi } \\
\text { Bisnis dan } \\
\text { Akuntansi }\end{array}$ & 26853523 & $\begin{array}{l}\text { UPT Penerbitan } \\
\text { Universitas } \\
\text { Jember }\end{array}$ & $\begin{array}{l}\text { Usulan Baru } \\
\text { mulai Volume } 5 \\
\text { Nomor } 1 \text { Tahun } \\
2018\end{array}$ \\
\hline & 35 & $\begin{array}{l}\text { Ekonomika Syariah: } \\
\text { Journal of Economic } \\
\text { Studies }\end{array}$ & 26148110 & IAIN Bukittinggi & $\begin{array}{l}\text { Usulan Baru } \\
\text { mulai Volume } 2 \\
\text { Nomor } 1 \text { Tahun } \\
2018\end{array}$ \\
\hline & 36 & Electro Luceat & 25974467 & $\begin{array}{l}\text { LPPM Politeknik } \\
\text { Katolik Saint } \\
\text { Paul Soorng }\end{array}$ & $\begin{array}{l}\text { Usulan Baru } \\
\text { mulai Volume } 4 \\
\text { Nomor } 1 \text { Tahun } \\
2018\end{array}$ \\
\hline
\end{tabular}




\begin{tabular}{|c|c|c|c|c|c|}
\hline \begin{tabular}{|l|} 
Peringkat \\
\end{tabular} & No. & Nama Jurnal & E-ISSN & Penerbit & Keterangan \\
\hline & 37 & $\begin{array}{l}\text { Elementary School: } \\
\text { Jurnal Pendidikan } \\
\text { dan Pembelajaran } \\
\text { ke SD-an }\end{array}$ & 25024264 & $\begin{array}{l}\text { Universitas PGRI } \\
\text { Yogyakarta }\end{array}$ & $\begin{array}{l}\text { Reakreditasi Naik } \\
\text { Peringkat dari } \\
\text { Peringkat } 6 \text { ke } \\
\text { Peringkat } 4 \text { mulai } \\
\text { Volume } 5 \text { Nomor } \\
2 \text { Tahun } 2018 \\
\end{array}$ \\
\hline & 38 & $\begin{array}{l}\text { English Teaching } \\
\text { Journal: A Journal } \\
\text { of English Literature, } \\
\text { Language, and } \\
\text { Education }\end{array}$ & 26864738 & $\begin{array}{l}\text { Universitas PGRI } \\
\text { Madiun }\end{array}$ & $\begin{array}{l}\text { Usulan Baru } \\
\text { mulai Volume } 6 \\
\text { Nomor } 1 \text { Tahun } \\
2018\end{array}$ \\
\hline & 39 & $\begin{array}{l}\text { Enlighten: Jurnal } \\
\text { Bimbingan } \\
\text { Konseling Islam }\end{array}$ & 26228920 & IAIN Langsa & $\begin{array}{l}\text { Usulan Baru } \\
\text { mulai Volume } 1 \\
\text { Nomor } 1 \text { Tahun } \\
2018\end{array}$ \\
\hline & 40 & $\begin{array}{l}\text { Equilibrium: Jurnal } \\
\text { Ekonomi, } \\
\text { Manajemen, } \\
\text { Akuntansi }\end{array}$ & 25989952 & $\begin{array}{l}\text { LPPM Universitas } \\
\text { Wijaya Kusuma } \\
\text { Surabaya }\end{array}$ & $\begin{array}{l}\text { Usulan Baru } \\
\text { mulai Volume } 14 \\
\text { Nomor } 1 \text { Tahun } \\
2018\end{array}$ \\
\hline & 41 & $\begin{array}{l}\text { Fidei: Jurnal Teologi } \\
\text { Sistematika dan } \\
\text { Praktika }\end{array}$ & 26218135 & $\begin{array}{l}\text { Sekolah Tinggi } \\
\text { Teologi } \\
\text { Tawangmangu }\end{array}$ & $\begin{array}{l}\text { Usulan Baru } \\
\text { mulai Volume } 1 \\
\text { Nomor } 1 \text { Tahun } \\
2018\end{array}$ \\
\hline & 42 & $\begin{array}{l}\text { Fullerene Journal of } \\
\text { Chemistry }\end{array}$ & 25985868 & $\begin{array}{l}\text { Jurusan Kimia, } \\
\text { Universitas } \\
\text { Negeri Manado }\end{array}$ & $\begin{array}{l}\text { Reakreditasi } \\
\text { Tetap di } \\
\text { Peringkat } 4 \text { mulai } \\
\text { Volume } 4 \text { Nomor } \\
2 \text { Tahun } 2019\end{array}$ \\
\hline & 43 & $\begin{array}{l}\text { Ghidza: Jurnal Gizi } \\
\text { dan Kesehatan }\end{array}$ & 26227622 & $\begin{array}{l}\text { Universitas } \\
\text { Tadulako }\end{array}$ & $\begin{array}{l}\text { Usulan Baru } \\
\text { mulai Volume } 2 \\
\text { Nomor } 1 \text { Tahun } \\
2018\end{array}$ \\
\hline & 44 & $\begin{array}{l}\text { Golden Age: Jurnal } \\
\text { Ilmiah Tumbuh } \\
\text { Kembang Anak Usia } \\
\text { Dini }\end{array}$ & 25023519 & $\begin{array}{l}\text { Universitas Islam } \\
\text { Negeri Sunan } \\
\text { Kalijaga }\end{array}$ & $\begin{array}{l}\text { Usulan Baru } \\
\text { mulai Volume } 3 \\
\text { Nomor } 1 \text { Tahun } \\
2018\end{array}$ \\
\hline
\end{tabular}

45. Hermeneutika ... 


\begin{tabular}{|c|c|c|c|c|c|}
\hline \begin{tabular}{|l|} 
Peringkat \\
\end{tabular} & No. & Nama Jurnal & E-ISSN & Penerbit & Keterangan \\
\hline & 45 & $\begin{array}{l}\text { Hermeneutika: } \\
\text { Jurnal } \\
\text { Hermeneutika }\end{array}$ & 26140055 & $\begin{array}{l}\text { Jurusan } \\
\text { Pendidikan } \\
\text { Sosiologi FKIP } \\
\text { Universitas } \\
\text { Sultan Ageng } \\
\text { Tirtayasa } \\
\text { Bekerjasama } \\
\text { dengan Asosiasi } \\
\text { Program Studi } \\
\text { Sosiologi } \\
\text { Indonesia (APSSI) } \\
\text { dan Ikatan } \\
\text { Sosiologi } \\
\text { Indonesia (ISI) }\end{array}$ & $\begin{array}{l}\text { Usulan Baru } \\
\text { mulai Volume } 4 \\
\text { Nomor } 1 \text { Tahun } \\
2018\end{array}$ \\
\hline & 46 & $\begin{array}{l}\text { IJCA (Indonesian } \\
\text { Journal of Chemical } \\
\text { Analysis) }\end{array}$ & 26227126 & $\begin{array}{l}\text { Universitas Islam } \\
\text { Indonesia }\end{array}$ & $\begin{array}{l}\text { Usulan Baru } \\
\text { mulai Volume } 1 \\
\text { Nomor } 1 \text { Tahun } \\
2018\end{array}$ \\
\hline & 47 & $\begin{array}{l}\text { IJID (International } \\
\text { Journal on } \\
\text { Informatics for } \\
\text { Development) }\end{array}$ & 25497448 & $\begin{array}{l}\text { Fakultas Sains } \\
\text { dan Teknologi } \\
\text { Universitas Islam } \\
\text { Negeri Sunan } \\
\text { Kalijaga } \\
\text { Yogyakarta } \\
\end{array}$ & $\begin{array}{l}\text { Usulan Baru } \\
\text { mulai Volume } 6 \\
\text { Nomor } 2 \text { Tahun } \\
2017\end{array}$ \\
\hline & 48 & $\begin{array}{l}\text { IJOLTL (Indonesian } \\
\text { Journal of Language } \\
\text { Teaching and } \\
\text { Linguistics) }\end{array}$ & 25028278 & $\begin{array}{l}\text { Center of } \\
\text { Language and } \\
\text { Cultural Studies }\end{array}$ & $\begin{array}{l}\text { Usulan Baru } \\
\text { mulai Volume } 3 \\
\text { Nomor } 2 \text { Tahun } \\
2018\end{array}$ \\
\hline & 49 & $\begin{array}{l}\text { Imara: Jurnal Riset } \\
\text { Ekonomi Islam }\end{array}$ & 26221918 & $\begin{array}{l}\text { Institut Agama } \\
\text { Islam Negeri } \\
\text { Batusangkar }\end{array}$ & $\begin{array}{l}\text { Usulan Baru } \\
\text { mulai Volume } 2 \\
\text { Nomor } 1 \text { Tahun } \\
2018\end{array}$ \\
\hline & 50 & $\begin{array}{l}\text { Indonesia } \\
\text { Accounting Journal }\end{array}$ & 26866609 & $\begin{array}{l}\text { Universitas Sam } \\
\text { Ratulangi }\end{array}$ & $\begin{array}{l}\text { Usulan Baru } \\
\text { mulai Volume } 1 \\
\text { Nomor } 1 \text { Tahun } \\
2019\end{array}$ \\
\hline & 51 & $\begin{array}{l}\text { Indonesian Journal } \\
\text { of Agricultural } \\
\text { Research }\end{array}$ & 26155842 & $\begin{array}{l}\text { Fakultas } \\
\text { Pertanian } \\
\text { Universitas } \\
\text { Sumatera Utara }\end{array}$ & $\begin{array}{l}\text { Usulan Baru } \\
\text { mulai Volume } 1 \\
\text { Nomor } 1 \text { Tahun } \\
2018\end{array}$ \\
\hline & 52 & $\begin{array}{l}\text { Indonesian Journal } \\
\text { of Learning } \\
\text { Education and } \\
\text { Counseling }\end{array}$ & 26228068 & $\begin{array}{l}\text { Institute for } \\
\text { Learning } \\
\text { Innovation and } \\
\text { Counseling }\end{array}$ & $\begin{array}{l}\text { Usulan Baru } \\
\text { mulai Volume } 1 \\
\text { Nomor } 1 \text { Tahun } \\
2018\end{array}$ \\
\hline & 53 & $\begin{array}{l}\text { Indonesian Journal } \\
\text { of Physical Medicine } \\
\& \text { Rehabilitation }\end{array}$ & 26217678 & $\begin{array}{l}\text { Perhimpunan } \\
\text { Besar } \\
\text { Kedokteran Fisik } \\
\text { dan Rehabilitasi } \\
\text { Indonesia }\end{array}$ & $\begin{array}{l}\text { Usulan Baru } \\
\text { mulai Volume } 6 \\
\text { Nomor } 2 \text { Tahun } \\
2017\end{array}$ \\
\hline
\end{tabular}




\begin{tabular}{|c|c|c|c|c|c|}
\hline Peringkat & No. & Nama Jurnal & E-ISSN & Penerbit & Keterangan \\
\hline & 54 & $\begin{array}{l}\text { Infomatek: Jurnal } \\
\text { Informatika, } \\
\text { Manajemen dan } \\
\text { Teknologi }\end{array}$ & 26147807 & $\begin{array}{l}\text { Fakultas Teknik } \\
\text { Universitas } \\
\text { Pasundan }\end{array}$ & $\begin{array}{l}\text { Usulan Baru } \\
\text { mulai Volume } 20 \\
\text { Nomor } 1 \text { Tahun } \\
2018\end{array}$ \\
\hline & 55 & $\begin{array}{l}\text { Inform: Jurnal } \\
\text { Ilmiah Bidang } \\
\text { Teknologi Informasi } \\
\text { dan Komunikasi }\end{array}$ & 25810367 & $\begin{array}{l}\text { Program Studi } \\
\text { Teknik } \\
\text { Informatika } \\
\text { Universitas } \\
\text { Dr.Soetomo }\end{array}$ & $\begin{array}{l}\text { Usulan Baru } \\
\text { mulai Volume } 3 \\
\text { Nomor } 2 \text { Tahun } \\
2018\end{array}$ \\
\hline & 56 & $\begin{array}{l}\text { Informatika: Jurnal } \\
\text { Informatika, } \\
\text { Manajemen dan } \\
\text { Komputer }\end{array}$ & 25803042 & $\begin{array}{l}\text { P3M STMIK } \\
\text { Dumai }\end{array}$ & $\begin{array}{l}\text { Usulan Baru } \\
\text { mulai Volume } 10 \\
\text { Nomor } 1 \text { Tahun } \\
2018\end{array}$ \\
\hline & 57 & $\begin{array}{l}\text { International } \\
\text { Journal of } \\
\text { Economics, Business } \\
\text { and Accounting } \\
\text { Research (IJEBAR) }\end{array}$ & 26141280 & $\begin{array}{l}\text { LPPM STIE AAS } \\
\text { Surakarta }\end{array}$ & $\begin{array}{l}\text { Usulan Baru } \\
\text { mulai Volume } 2 \\
\text { Nomor } 1 \text { Tahun } \\
2018\end{array}$ \\
\hline & 58 & $\begin{array}{l}\text { Intiqad: Jurnal } \\
\text { Agama dan } \\
\text { Pendidikan Islam }\end{array}$ & 25980033 & $\begin{array}{l}\text { Universitas } \\
\text { Muhammadiyash } \\
\text { Sumatera Utara }\end{array}$ & $\begin{array}{l}\text { Reakreditasi } \\
\text { Tetap di } \\
\text { Peringkat } 4 \text { mulai } \\
\text { Volume } 11 \\
\text { Nomor } 2 \text { Tahun } \\
2019\end{array}$ \\
\hline & 59 & $\begin{array}{l}\text { Islamic Studies } \\
\text { Journal for Social } \\
\text { Transformation }\end{array}$ & 26860619 & $\begin{array}{l}\text { Lembaga } \\
\text { Penelitian dan } \\
\text { Pengabdian } \\
\text { kepada } \\
\text { Masyarakat IAIN } \\
\text { Pekalongan }\end{array}$ & $\begin{array}{l}\text { Reakreditasi } \\
\text { Tetap di } \\
\text { Peringkat } 4 \text { mulai } \\
\text { Volume } 3 \text { Nomor } \\
2 \text { Tahun } 2019\end{array}$ \\
\hline & 60 & $\begin{array}{l}\text { JCES (Journal of } \\
\text { Character Education } \\
\text { Society) }\end{array}$ & 26143666 & $\begin{array}{l}\text { Universitas } \\
\text { Muhammadiyah } \\
\text { Mataram }\end{array}$ & $\begin{array}{l}\text { Usulan Baru } \\
\text { mulai Volume } 1 \\
\text { Nomor } 2 \text { Tahun } \\
2018\end{array}$ \\
\hline & 61 & $\begin{array}{l}\text { JECCE (Journal of } \\
\text { Early Childhood } \\
\text { Care and Education) }\end{array}$ & 26151413 & $\begin{array}{l}\text { Universitas } \\
\text { Ahmad Dahlan }\end{array}$ & $\begin{array}{l}\text { Usulan Baru } \\
\text { mulai Volume } 1 \\
\text { Nomor } 1 \text { Tahun } \\
2018\end{array}$ \\
\hline & 62 & Jendela Olahraga & 25797662 & $\begin{array}{l}\text { Universitas PGRI } \\
\text { Semarang }\end{array}$ & $\begin{array}{l}\text { Reakreditasi Naik } \\
\text { Peringkat dari } \\
\text { Peringkat } 5 \text { ke } \\
\text { Peringkat } 4 \text { mulai } \\
\text { Volume } 5 \text { Nomor } \\
1 \text { Tahun } 2020\end{array}$ \\
\hline & 63 & $\begin{array}{l}\text { JGISE-Journal of } \\
\text { Geospatial } \\
\text { Information Science } \\
\text { and Engineerin }\end{array}$ & 26231182 & $\begin{array}{l}\text { Universitas } \\
\text { Gadjah Mada }\end{array}$ & $\begin{array}{l}\text { Usulan Baru } \\
\text { mulai Volume } 1 \\
\text { Nomor } 1 \text { Tahun } \\
2018\end{array}$ \\
\hline
\end{tabular}




\begin{tabular}{|c|c|c|c|c|c|}
\hline \begin{tabular}{|l|} 
Peringkat \\
\end{tabular} & No. & Nama Jurnal & E-ISSN & Penerbit & Keterangan \\
\hline & 64 & $\begin{array}{l}\text { JIPI (Jurnal Ilmiah } \\
\text { Penelitian dan } \\
\text { Pembelajaran } \\
\text { Informatika) }\end{array}$ & 25408984 & $\begin{array}{l}\text { Prodi Pendidikan } \\
\text { Teknologi } \\
\text { Informasi STKIP } \\
\text { PGRI } \\
\text { Tulungagung }\end{array}$ & $\begin{array}{l}\text { Reakreditasi } \\
\text { Tetap di } \\
\text { Peringkat } 4 \\
\text { mulai Volume } 4 \\
\text { Nomor } 2 \text { Tahun } \\
2019 \\
\end{array}$ \\
\hline & 65 & $\begin{array}{l}\text { JIRE (Jurnal } \\
\text { Informatika dan } \\
\text { Rekayasa } \\
\text { Elektronik) }\end{array}$ & 26206900 & $\begin{array}{l}\text { Lembaga } \\
\text { Penelitian dan } \\
\text { pengabdian } \\
\text { Masyarakat } \\
\text { STMIK Lombok } \\
\end{array}$ & $\begin{array}{l}\text { Usulan Baru } \\
\text { mulai Volume } 1 \\
\text { Nomor } 1 \text { Tahun } \\
2018\end{array}$ \\
\hline & 66 & $\begin{array}{l}\text { Journal of } \\
\text { Administration and } \\
\text { Educational } \\
\text { Management } \\
\text { (ALIGNMENT) }\end{array}$ & 25985159 & $\begin{array}{l}\text { Institut } \\
\text { Penelitian } \\
\text { Matematika, } \\
\text { Komputer, } \\
\text { Keperawatan, } \\
\text { Pendidikan dan } \\
\text { Ekonomi } \\
\text { (IPM2KPE) }\end{array}$ & $\begin{array}{l}\text { Usulan Baru } \\
\text { mulai Volume } 1 \\
\text { Nomor } 1 \text { Tahun } \\
2018\end{array}$ \\
\hline & 67 & $\begin{array}{l}\text { Journal of } \\
\text { Agromedicine and } \\
\text { Medical Science }\end{array}$ & 24609048 & $\begin{array}{l}\text { UPT Penerbitan } \\
\text { Universitas } \\
\text { Jember }\end{array}$ & $\begin{array}{l}\text { Usulan Baru } \\
\text { mulai Volume } 4 \\
\text { Nomor } 1 \text { Tahun } \\
2018\end{array}$ \\
\hline & 68 & $\begin{array}{l}\text { Journal of Earth } \\
\text { Energy Science, } \\
\text { Engineering, and } \\
\text { Technology }\end{array}$ & E26140268 & $\begin{array}{l}\text { Universitas } \\
\text { Trisakti }\end{array}$ & $\begin{array}{l}\text { Usulan Baru } \\
\text { mulai Volume } 1 \\
\text { Nomor } 2 \text { Tahun } \\
2018\end{array}$ \\
\hline & 69 & $\begin{array}{l}\text { Journal of Education } \\
\text { and Instruction } \\
\text { (JOEAI) }\end{array}$ & 26148617 & $\begin{array}{l}\text { Institut } \\
\text { Penelitian } \\
\text { Matematika, } \\
\text { Komputer, } \\
\text { Keperawatan, } \\
\text { Pendidikan dan } \\
\text { Ekonomi } \\
\text { (IPM2KPE) }\end{array}$ & $\begin{array}{l}\text { Usulan Baru } \\
\text { mulai Volume } 1 \\
\text { Nomor } 1 \text { Tahun } \\
2018\end{array}$ \\
\hline & 70 & $\begin{array}{l}\text { Journal of English } \\
\text { Education and } \\
\text { Teaching }\end{array}$ & 26225867 & $\begin{array}{l}\text { Fakultas } \\
\text { Keguruan dan } \\
\text { Ilmu Pendidikan } \\
\text { Universitas } \\
\text { Bengkulu }\end{array}$ & $\begin{array}{l}\text { Reakreditasi Naik } \\
\text { Peringkat dari } \\
\text { Peringkat } 5 \text { ke } \\
\text { Peringkat } 4 \text { mulai } \\
\text { Volume } 3 \text { Nomor } \\
4 \text { Tahun } 2019\end{array}$ \\
\hline & 71 & $\begin{array}{l}\text { Journal of } \\
\text { Information } \\
\text { Technology and } \\
\text { Computer Science } \\
\text { (INTECOMS) }\end{array}$ & 26141574 & $\begin{array}{l}\text { Institut } \\
\text { Penelitian } \\
\text { Matematika, } \\
\text { Komputer, } \\
\text { Keperawatan, } \\
\text { Pendidikan dan } \\
\text { Ekonomi } \\
\text { (IPM2KPE) }\end{array}$ & $\begin{array}{l}\text { Usulan Baru } \\
\text { mulai Volume } 1 \\
\text { Nomor } 1 \text { Tahun } \\
2018\end{array}$ \\
\hline
\end{tabular}




\begin{tabular}{|c|c|c|c|c|c|}
\hline Peringkat & No. & Nama Jurnal & E-ISSN & Penerbit & Keterangan \\
\hline & 72 & $\begin{array}{l}\text { Journal of Integrated } \\
\text { System }\end{array}$ & 26217104 & $\begin{array}{l}\text { Program Studi } \\
\text { Teknik Industri, } \\
\text { Universitas } \\
\text { Kristen } \\
\text { Maranatha }\end{array}$ & $\begin{array}{l}\text { Usulan Baru } \\
\text { mulai Volume } 1 \\
\text { Nomor } 1 \text { Tahun } \\
2018\end{array}$ \\
\hline & 73 & $\begin{array}{l}\text { Journal of Livestock } \\
\text { and Animal Health }\end{array}$ & 26552159 & $\begin{array}{l}\text { Politeknik } \\
\text { Pertaninan } \\
\text { Negeri } \\
\text { Payakumbuh }\end{array}$ & $\begin{array}{l}\text { Usulan Baru } \\
\text { mulai Volume } 1 \\
\text { Nomor } 1 \text { Tahun } \\
2018\end{array}$ \\
\hline & 74 & $\begin{array}{l}\text { J-SAKTI (Jurnal } \\
\text { Sains Komputer } \\
\text { dan Informatika) }\end{array}$ & 25497200 & $\begin{array}{l}\text { STIKOM Tunas } \\
\text { Pematang } \\
\text { Siantar }\end{array}$ & $\begin{array}{l}\text { Reakreditasi Naik } \\
\text { Peringkat dari } \\
\text { Peringkat } 5 \text { ke } \\
\text { Peringkat } 4 \text { mulai } \\
\text { Volume } 3 \text { Nomor } \\
2 \text { Tahun } 2019 \\
\end{array}$ \\
\hline & 75 & $\begin{array}{l}\text { JTI: Jurnal Teknik } \\
\text { Industri }\end{array}$ & 27146235 & $\begin{array}{l}\text { Industrial } \\
\text { Engineering } \\
\text { Department } \\
\text { Universitas Islam } \\
\text { Negeri Sultan } \\
\text { Syarif Kasim } \\
\text { Riau }\end{array}$ & $\begin{array}{l}\text { Usulan Baru } \\
\text { mulai Volume } 1 \\
\text { Nomor } 2 \text { Tahun } \\
2018\end{array}$ \\
\hline & 76 & Jurnal Agribest & 26154862 & $\begin{array}{l}\text { Universitas } \\
\text { Muhammadiyah } \\
\text { Jember }\end{array}$ & $\begin{array}{l}\text { Reakreditasi Naik } \\
\text { Peringkat dari } \\
\text { Peringkat } 5 \text { ke } \\
\text { Peringkat } 4 \text { mulai } \\
\text { Volume } 3 \text { Nomor } \\
2 \text { Tahun } 2019\end{array}$ \\
\hline & 77 & $\begin{array}{l}\text { Jurnal Arsitektur } \\
\text { Zonasi }\end{array}$ & 26209934 & $\begin{array}{l}\text { Universitas } \\
\text { Pendidikan } \\
\text { Indonesia }\end{array}$ & $\begin{array}{l}\text { Usulan Baru } \\
\text { mulai Volume } 1 \\
\text { Nomor } 1 \text { Tahun } \\
2018\end{array}$ \\
\hline & 78 & Jurnal Ecosolum & $2654430 X$ & $\begin{array}{l}\text { Fakultas } \\
\text { Pertanian, } \\
\text { Universitas } \\
\text { Hasanuddin }\end{array}$ & $\begin{array}{l}\text { Usulan Baru } \\
\text { mulai Volume } 7 \\
\text { Nomor } 1 \text { Tahun } \\
2018\end{array}$ \\
\hline & 79 & $\begin{array}{l}\text { Jurnal Entrepreneur } \\
\text { dan } \\
\text { Entrepreneurship }\end{array}$ & 25809393 & $\begin{array}{l}\text { Universitas } \\
\text { Ciputra } \\
\text { Surabaya }\end{array}$ & $\begin{array}{l}\text { Reakreditasi } \\
\text { Tetap di } \\
\text { Peringkat } 4 \text { mulai } \\
\text { Volume } 8 \text { Nomor } \\
2 \text { Tahun } 2019\end{array}$ \\
\hline & 80 & $\begin{array}{l}\text { Jurnal Fundadikdas } \\
\text { (Fundamental } \\
\text { Pendidikan Dasar) }\end{array}$ & 26141620 & $\begin{array}{l}\text { Universitas } \\
\text { Ahmad Dahlan }\end{array}$ & $\begin{array}{l}\text { Usulan Baru } \\
\text { mulai Volume } 1 \\
\text { Nomor } 1 \text { Tahun } \\
2018\end{array}$ \\
\hline & 81 & $\begin{array}{l}\text { Jurnal Geofisika } \\
\text { Eksplorasi }\end{array}$ & 26856182 & $\begin{array}{l}\text { Universitas } \\
\text { Lampung }\end{array}$ & $\begin{array}{l}\text { Usulan Baru } \\
\text { mulai Volume } 4 \\
\text { Nomor } 1 \text { Tahun } \\
2018\end{array}$ \\
\hline
\end{tabular}

82. Jurnal ... 


\begin{tabular}{|c|c|c|c|c|c|}
\hline \begin{tabular}{|l|} 
Peringkat \\
\end{tabular} & No. & Nama Jurnal & E-ISSN & Penerbit & Keterangan \\
\hline & 82 & Jurnal Gizi & 25804847 & $\begin{array}{l}\text { Program Studi } \\
\text { Gizi Fakultas } \\
\text { Ilmu } \\
\text { Keperawatan dan } \\
\text { Kesehatan } \\
\text { Universitas } \\
\text { Muhammadiyah } \\
\text { Semarang }\end{array}$ & $\begin{array}{l}\text { Reakreditasi Naik } \\
\text { Peringkat dari } \\
\text { Peringkat } 5 \text { ke } \\
\text { Peringkat } 4 \text { mulai } \\
\text { Volume } 8 \text { Nomor } \\
2 \text { Tahun } 2019\end{array}$ \\
\hline & 83 & $\begin{array}{l}\text { Jurnal HPJI } \\
\text { (Himpunan } \\
\text { Pengembangan } \\
\text { Jalan Indonesia) }\end{array}$ & 26544873 & $\begin{array}{l}\text { Universitas } \\
\text { Katolik } \\
\text { Parahyangan }\end{array}$ & $\begin{array}{l}\text { Usulan Baru } \\
\text { mulai Volume } 4 \\
\text { Nomor } 1 \text { Tahun } \\
2018\end{array}$ \\
\hline & 84 & $\begin{array}{l}\text { Jurnal Hukum } \\
\text { Bisnis Bonum } \\
\text { Commune }\end{array}$ & 26229668 & $\begin{array}{l}\text { Universitas } 17 \\
\text { Agustus } 1945 \\
\text { Surabaya }\end{array}$ & $\begin{array}{l}\text { Usulan Baru } \\
\text { mulai Volume } 1 \\
\text { Nomor } 1 \text { Tahun } \\
2018\end{array}$ \\
\hline & 85 & $\begin{array}{l}\text { Jurnal Hukum } \\
\text { Magnum Opus }\end{array}$ & $2623274 X$ & $\begin{array}{l}\text { Universitas } 17 \\
\text { Agustus } 1945 \\
\text { Surabaya }\end{array}$ & $\begin{array}{l}\text { Usulan Baru } \\
\text { mulai Volume } 1 \\
\text { Nomor } 1 \text { Tahun } \\
2018\end{array}$ \\
\hline & 86 & $\begin{array}{l}\text { Jurnal ICMES: The } \\
\text { Journal of Middle } \\
\text { East Studies }\end{array}$ & 26217341 & $\begin{array}{l}\text { Indonesia Center } \\
\text { for Middle East } \\
\text { Studies }\end{array}$ & $\begin{array}{l}\text { Usulan Baru } \\
\text { mulai Volume } 2 \\
\text { Nomor } 1 \text { Tahun } \\
2018\end{array}$ \\
\hline & 87 & $\begin{array}{l}\text { Jurnal Ilmiah } \\
\text { Fonema: Jurnal } \\
\text { Edukasi Bahasa } \\
\text { dan Sastra } \\
\text { Indonesia }\end{array}$ & 26212900 & $\begin{array}{l}\text { Universitas } \\
\text { Soetomo } \\
\text { Surabaya }\end{array}$ & $\begin{array}{l}\text { Usulan Baru } \\
\text { mulai Volume } 1 \\
\text { Nomor } 1 \text { Tahun } \\
2018\end{array}$ \\
\hline & 88 & $\begin{array}{l}\text { Jurnal Ilmiah } \\
\text { Informatika }\end{array}$ & 25496301 & $\begin{array}{l}\text { Universitas } \\
\text { Ibrahimy }\end{array}$ & $\begin{array}{l}\text { Usulan Baru } \\
\text { mulai Volume } 3 \\
\text { Nomor } 1 \text { Tahun } \\
2018\end{array}$ \\
\hline & 89 & $\begin{array}{l}\text { Jurnal Ilmiah } \\
\text { Kesehatan (Journal } \\
\text { of Health Sciences) }\end{array}$ & 24773948 & $\begin{array}{l}\text { Universitas } \\
\text { Nahdlatul Ulama } \\
\text { Surabaya }\end{array}$ & $\begin{array}{l}\text { Reakreditasi Naik } \\
\text { Peringkat dari } \\
\text { Peringkat } 5 \text { ke } \\
\text { Peringkat } 4 \text { mulai } \\
\text { Volume } 13 \\
\text { Nomor } 1 \text { Tahun } \\
2020\end{array}$ \\
\hline & 90 & $\begin{array}{l}\text { Jurnal Ilmiah } \\
\text { Permas: Jurnal } \\
\text { Ilmiah STIKES } \\
\text { Kendal }\end{array}$ & 25498134 & $\begin{array}{l}\text { LPPM STIKES } \\
\text { Kendal }\end{array}$ & $\begin{array}{l}\text { Reakreditasi } \\
\text { Tetap di } \\
\text { Peringkat } 4 \text { mulai } \\
\text { Volume } 10 \\
\text { Nomor } 1 \text { Tahun } \\
2020\end{array}$ \\
\hline
\end{tabular}

91. Jurnal ... 


\begin{tabular}{|c|c|c|c|c|c|}
\hline Peringkat & No. & Nama Jurnal & E-ISSN & Penerbit & Keterangan \\
\hline & 91 & Jurnal Ilmiah Platax & 23023589 & $\begin{array}{l}\text { Fakultas } \\
\text { Perikanan Dan } \\
\text { Ilmu Kelautan, } \\
\text { Universitas Sam } \\
\text { Ratulangi }\end{array}$ & $\begin{array}{l}\text { Reakreditasi } \\
\text { Tetap di } \\
\text { Peringkat } 4 \text { mulai } \\
\text { Volume } 8 \text { Nomor } \\
1 \text { Tahun } 2020\end{array}$ \\
\hline & 92 & $\begin{array}{l}\text { Jurnal Ilmiah Poli } \\
\text { Bisnis }\end{array}$ & 26561212 & $\begin{array}{l}\text { Politeknik Negeri } \\
\text { Padang }\end{array}$ & $\begin{array}{l}\text { Usulan Baru } \\
\text { mulai Volume } 10 \\
\text { Nomor } 1 \text { Tahun } \\
2018\end{array}$ \\
\hline & 93 & $\begin{array}{l}\text { Jurnal Ilmiah } \\
\text { Universitas } \\
\text { Batanghari Jambi }\end{array}$ & 25494236 & $\begin{array}{l}\text { Lembaga } \\
\text { Penelitian dan } \\
\text { Pengabdian pada } \\
\text { Masyarakat, } \\
\text { Universitas } \\
\text { Batanghari }\end{array}$ & $\begin{array}{l}\text { Reakreditasi Naik } \\
\text { Peringkat dari } \\
\text { Peringkat } 5 \text { ke } \\
\text { Peringkat } 4 \text { mulai } \\
\text { Volume } 20 \\
\text { Nomor } 1 \text { Tahun } \\
2020\end{array}$ \\
\hline & 94 & $\begin{array}{l}\text { Jurnal Ilmu } \\
\text { Kelautan } \\
\text { Kepulauan }\end{array}$ & $2620570 X$ & $\begin{array}{l}\text { Program Studi } \\
\text { Ilmu Kelautan. } \\
\text { Fakultas } \\
\text { Perikanan dan } \\
\text { Kelautan. } \\
\text { Universitas } \\
\text { Khairun, Ternate }\end{array}$ & $\begin{array}{l}\text { Usulan Baru } \\
\text { mulai Volume } 1 \\
\text { Nomor } 1 \text { Tahun } \\
2018\end{array}$ \\
\hline & 95 & $\begin{array}{l}\text { Jurnal Ilmu } \\
\text { Keperawatan } \\
\text { Medikal Bedah }\end{array}$ & 26212986 & $\begin{array}{l}\text { Persatuan } \\
\text { Perawat Nasional } \\
\text { Indonesia (PPNI) } \\
\text { Jawa Tengah }\end{array}$ & $\begin{array}{l}\text { Usulan Baru } \\
\text { mulai Volume } 1 \\
\text { Nomor } 1 \text { Tahun } \\
2018\end{array}$ \\
\hline & 96 & Jurnal Iqtisaduna & 25500295 & $\begin{array}{l}\text { Fakultas } \\
\text { Ekonomi dan } \\
\text { Bisnis Islam UIN } \\
\text { Alaudddin } \\
\text { Makassar }\end{array}$ & $\begin{array}{l}\text { Reakreditasi } \\
\text { Tetap di } \\
\text { Peringkat } 4 \text { mulai } \\
\text { Volume } 5 \text { Nomor } \\
2 \text { Tahun } 2019\end{array}$ \\
\hline & 97 & $\begin{array}{l}\text { Jurnal Justisia: } \\
\text { Jurnal Ilmu } \\
\text { Hukum, } \\
\text { Perundang- } \\
\text { undangan dan } \\
\text { Pranata Sosial } \\
\end{array}$ & 26145642 & $\begin{array}{l}\text { Universitas Islam } \\
\text { Negeri Ar-Raniry } \\
\text { Banda Aceh }\end{array}$ & $\begin{array}{l}\text { Usulan Baru } \\
\text { mulai Volume } 3 \\
\text { Nomor } 1 \text { Tahun } \\
2018\end{array}$ \\
\hline & 98 & Jurnal Karinov & 26206161 & $\begin{array}{l}\text { Universitas } \\
\text { Negeri Malang }\end{array}$ & $\begin{array}{l}\text { Usulan Baru } \\
\text { mulai Volume } 1 \\
\text { Nomor } 2 \text { Tahun } \\
2018\end{array}$ \\
\hline & 99 & $\begin{array}{l}\text { Jurnal Kebidanan } \\
\text { dan Kesehatan } \\
\text { Tradisional }\end{array}$ & 25805207 & $\begin{array}{l}\text { Politeknik } \\
\text { Kesehatan } \\
\text { Surakarta }\end{array}$ & $\begin{array}{l}\text { Reakreditasi Naik } \\
\text { Peringkat dari } \\
\text { Peringkat } 6 \text { ke } \\
\text { Peringkat } 4 \text { mulai } \\
\text { Volume } 5 \text { Nomor } \\
1 \text { Tahun } 2020 \\
\end{array}$ \\
\hline
\end{tabular}




\begin{tabular}{|c|c|c|c|c|c|}
\hline \begin{tabular}{|l|} 
Peringkat \\
\end{tabular} & No. & Nama Jurnal & E-ISSN & Penerbit & Keterangan \\
\hline & 100 & $\begin{array}{l}\text { Jurnal Keperawatan } \\
\text { Jiwa }\end{array}$ & 26558106 & $\begin{array}{l}\text { FIKKeS } \\
\text { Universitas } \\
\text { Muhammadiyah } \\
\text { Semarang }\end{array}$ & $\begin{array}{l}\text { Reakreditasi } \\
\text { Tetap di } \\
\text { Peringkat } 4 \text { mulai } \\
\text { Volume } 8 \text { Nomor } \\
1 \text { Tahun } 2020\end{array}$ \\
\hline & 101 & $\begin{array}{l}\text { Jurnal KIBASP } \\
\text { (Kajian Bahasa, } \\
\text { Sastra dan } \\
\text { Pengajaran) }\end{array}$ & 25975218 & $\begin{array}{l}\text { Institut } \\
\text { Penelitian } \\
\text { Matematika, } \\
\text { Komputer, } \\
\text { Keperawatan, } \\
\text { Pendidikan, dan } \\
\text { Ekonomi } \\
\text { (IPM2KPE) } \\
\end{array}$ & $\begin{array}{l}\text { Reakreditasi } \\
\text { Tetap di } \\
\text { Peringkat } 4 \text { mulai } \\
\text { Volume } 3 \text { Nomor } \\
1 \text { Tahun } 2019\end{array}$ \\
\hline & 102 & $\begin{array}{l}\text { Jurnal Kumparan } \\
\text { Fisika }\end{array}$ & 26551403 & $\begin{array}{l}\text { Universitas } \\
\text { Bengkulu }\end{array}$ & $\begin{array}{l}\text { Usulan Baru } \\
\text { mulai Volume } 1 \\
\text { Nomor } 1 \text { Tahun } \\
2018\end{array}$ \\
\hline & 103 & $\begin{array}{l}\text { Jurnal Mutu } \\
\text { Pangan: Indonesian } \\
\text { Journal of Food } \\
\text { Quality }\end{array}$ & 26849550 & $\begin{array}{l}\text { Departemen Ilmu } \\
\text { dan Teknologi } \\
\text { Pangan, Institut } \\
\text { Pertanian Bogor }\end{array}$ & $\begin{array}{l}\text { Usulan Baru } \\
\text { mulai Volume } 5 \\
\text { Nomor } 1 \text { Tahun } \\
2018\end{array}$ \\
\hline & 104 & $\begin{array}{l}\text { Jurnal Pendidikan } \\
\text { Dasar }\end{array}$ & 25495801 & $\begin{array}{l}\text { Program } \\
\text { Pascasarjana, } \\
\text { Universitas } \\
\text { Negeri Jakarta }\end{array}$ & $\begin{array}{l}\text { Usulan Baru } \\
\text { mulai Volume } 9 \\
\text { Nomor } 1 \text { Tahun } \\
2018\end{array}$ \\
\hline & 105 & $\begin{array}{l}\text { Jurnal Pendidikan } \\
\text { Matematika: Judika } \\
\text { Education }\end{array}$ & 26146088 & $\begin{array}{l}\text { Institut } \\
\text { Penelitian } \\
\text { Matematika, } \\
\text { Komputer, } \\
\text { Keperawatan, } \\
\text { Pendidikan dan } \\
\text { Ekonomi } \\
\text { (IPM2KPE) }\end{array}$ & $\begin{array}{l}\text { Usulan Baru } \\
\text { mulai Volume } 1 \\
\text { Nomor } 1 \text { Tahun } \\
2018\end{array}$ \\
\hline & 106 & $\begin{array}{l}\text { Jurnal Pendidikan } \\
\text { Sejarah }\end{array}$ & 25809180 & $\begin{array}{l}\text { LPPM Universitas } \\
\text { Negeri Jakarta }\end{array}$ & $\begin{array}{l}\text { Reakreditasi Naik } \\
\text { Peringkat dari } \\
\text { Peringkat } 6 \text { ke } \\
\text { Peringkat } 4 \text { mulai } \\
\text { Volume } 7 \text { Nomor } \\
2 \text { Tahun } 2018\end{array}$ \\
\hline & 107 & $\begin{array}{l}\text { Jurnal Pendidikan } \\
\text { Sejarah Indonesia }\end{array}$ & 26221837 & $\begin{array}{l}\text { Universitas } \\
\text { Negeri Malang }\end{array}$ & $\begin{array}{l}\text { Usulan Baru } \\
\text { mulai Volume } 1 \\
\text { Nomor } 1 \text { Tahun } \\
2018\end{array}$ \\
\hline & 108 & $\begin{array}{l}\text { Jurnal Penelitian } \\
\text { Humaniora }\end{array}$ & 25414496 & $\begin{array}{l}\text { Lembaga } \\
\text { Penelitian dan } \\
\text { Pengabdian } \\
\text { Masyarakat } \\
\text { Universitas } \\
\text { Muhammadiyah } \\
\text { Surakarta }\end{array}$ & $\begin{array}{l}\text { Reakreditasi Naik } \\
\text { Peringkat dari } \\
\text { Peringkat } 5 \text { ke } \\
\text { Peringkat } 4 \text { mulai } \\
\text { Volume } 21 \\
\text { Nomor } 1 \text { Tahun } \\
20208\end{array}$ \\
\hline
\end{tabular}




\begin{tabular}{|c|c|c|c|c|c|}
\hline Peringkat & No. & Nama Jurnal & E-ISSN & Penerbit & Keterangan \\
\hline & 109 & $\begin{array}{l}\text { Jurnal Penelitian } \\
\text { Transportasi Laut }\end{array}$ & 25484087 & $\begin{array}{l}\text { Puslitbang } \\
\text { Transportasi } \\
\text { Laut, Sungai, } \\
\text { Danau, dan } \\
\text { Penyeberangan }\end{array}$ & $\begin{array}{l}\text { Usulan Baru } \\
\text { mulai Volume } 19 \\
\text { Nomor } 2 \text { Tahun } \\
2017\end{array}$ \\
\hline & 110 & $\begin{array}{l}\text { Jurnal Persatuan } \\
\text { Perawat Nasional } \\
\text { Indonesia (JPPNI) }\end{array}$ & 25498576 & $\begin{array}{l}\text { Dewan Pengurus } \\
\text { Pusat Persatuan } \\
\text { Perawat Nasional } \\
\text { Indonesia }\end{array}$ & $\begin{array}{l}\text { Usulan Baru } \\
\text { mulai Volume } 3 \\
\text { Nomor } 1 \text { Tahun } \\
2018\end{array}$ \\
\hline & 111 & Jurnal Planoearth & 26154226 & $\begin{array}{l}\text { Universitas } \\
\text { Muhammadiyah } \\
\text { Mataram }\end{array}$ & $\begin{array}{l}\text { Usulan Baru } \\
\text { mulai Volume } 3 \\
\text { Nomor } 1 \text { Tahun } \\
2018\end{array}$ \\
\hline & 112 & $\begin{array}{l}\text { Jurnal Ruaya: } \\
\text { Jurnal Penelitian } \\
\text { dan Kajian Ilmu } \\
\text { Perikanan dan } \\
\text { Kelautan }\end{array}$ & 25413155 & $\begin{array}{l}\text { Universitas } \\
\text { Muhammadiyah } \\
\text { Pontianak }\end{array}$ & $\begin{array}{l}\text { Reakreditasi Naik } \\
\text { Peringkat dari } \\
\text { Peringkat } 5 \text { ke } \\
\text { Peringkat } 4 \text { mulai } \\
\text { Volume } 8 \text { Nomor } \\
1 \text { Tahun } 2020\end{array}$ \\
\hline & 113 & $\begin{array}{l}\text { Jurnal Sains dan } \\
\text { Informatika: } \\
\text { Research of Science } \\
\text { and Informatic }\end{array}$ & $2502096 \mathrm{X}$ & $\begin{array}{l}\text { Lembaga } \\
\text { Layanan } \\
\text { Pendidikan } \\
\text { Tinggi Wilayah X }\end{array}$ & $\begin{array}{l}\text { Reakreditasi } \\
\text { Tetap di } \\
\text { Peringkat } 4 \text { mulai } \\
\text { Volume } 5 \text { Nomor } \\
2 \text { Tahun } 2019\end{array}$ \\
\hline & 114 & $\begin{array}{l}\text { Jurnal Sains dan } \\
\text { Teknologi Maritim }\end{array}$ & 26232030 & $\begin{array}{l}\text { Sekolah Tinggi } \\
\text { Maritim dan } \\
\text { Transport "AMNI" } \\
\text { Semarang }\end{array}$ & $\begin{array}{l}\text { Usulan Baru } \\
\text { mulai Volume } 17 \\
\text { Nomor } 2 \text { Tahun } \\
2018\end{array}$ \\
\hline & 115 & Jurnal Seni Tari & 22526714 & $\begin{array}{l}\text { Universitas } \\
\text { Negeri Semarang }\end{array}$ & $\begin{array}{l}\text { Reakreditasi Naik } \\
\text { Peringkat dari } \\
\text { Peringkat } 5 \text { ke } \\
\text { Peringkat } 4 \text { mulai } \\
\text { Volume } 8 \text { Nomor } \\
2 \text { Tahun } 2019 \\
\end{array}$ \\
\hline & 116 & $\begin{array}{l}\text { Jurnal Techno Nusa } \\
\text { Mandiri }\end{array}$ & $2527676 \mathrm{X}$ & $\begin{array}{l}\text { LPPM STMIK } \\
\text { Nusa Mandiri } \\
\text { Jakarta }\end{array}$ & $\begin{array}{l}\text { Reakreditasi } \\
\text { Tetap di } \\
\text { Peringkat } 4 \text { mulai } \\
\text { Volume } 16 \\
\text { Nomor } 2 \text { Tahun } \\
2019\end{array}$ \\
\hline & 117 & Jurnal Teknik & 27157660 & $\begin{array}{l}\text { Universitas } \\
\text { Negeri Gorontalo }\end{array}$ & $\begin{array}{l}\text { Usulan Baru } \\
\text { mulai Volume } 16 \\
\text { Nomor } 1 \text { Tahun } \\
2018\end{array}$ \\
\hline
\end{tabular}




\begin{tabular}{|c|c|c|c|c|c|}
\hline Peringkat & No. & Nama Jurnal & E-ISSN & Penerbit & Keterangan \\
\hline & 118 & Jurnal Ternak & 26846799 & $\begin{array}{l}\text { Fakultas } \\
\text { Peternakan - } \\
\text { Universitas Islam } \\
\text { Lamongan }\end{array}$ & $\begin{array}{l}\text { Reakreditasi Naik } \\
\text { Peringkat dari } \\
\text { Peringkat } 5 \text { ke } \\
\text { Peringkat } 4 \text { mulai } \\
\text { Volume } 10 \\
\text { Nomor } 2 \text { Tahun } \\
2019\end{array}$ \\
\hline & 119 & $\begin{array}{l}\text { Justindo (Jurnal } \\
\text { Sistem dan } \\
\text { Teknologi Informasi } \\
\text { Indonesia) }\end{array}$ & 25415735 & $\begin{array}{l}\text { Universitas } \\
\text { Muhammadiyah } \\
\text { Jember }\end{array}$ & $\begin{array}{l}\text { Usulan Baru } \\
\text { mulai Volume } 3 \\
\text { Nomor } 1 \text { Tahun } \\
2018\end{array}$ \\
\hline & 120 & $\begin{array}{l}\text { Kacanegara Jurnal } \\
\text { Pengabdian pada } \\
\text { Masyarakat }\end{array}$ & 26572338 & $\begin{array}{l}\text { Sekolah Tinggi } \\
\text { Teknologi } \\
\text { Adisutjipto }\end{array}$ & $\begin{array}{l}\text { Usulan Baru } \\
\text { mulai Volume } 1 \\
\text { Nomor } 1 \text { Tahun } \\
2018\end{array}$ \\
\hline & 121 & $\begin{array}{l}\text { KAGANGA: Jurnal } \\
\text { Pendidikan Sejarah } \\
\text { dan Riset Sosial- } \\
\text { Humaniora }\end{array}$ & 25984934 & $\begin{array}{l}\text { Institut } \\
\text { Penelitian } \\
\text { Matematika, } \\
\text { Komputer, } \\
\text { Keperawatan, } \\
\text { Pendidikan dan } \\
\text { Ekonomi } \\
\text { (IPM2KPE) } \\
\end{array}$ & $\begin{array}{l}\text { Usulan Baru } \\
\text { mulai Volume } 1 \\
\text { Nomor } 1 \text { Tahun } \\
2018\end{array}$ \\
\hline & 122 & Kebudayaan & 26858088 & $\begin{array}{l}\text { Kementerian } \\
\text { Pendidikan dan } \\
\text { Kebudayaan }\end{array}$ & $\begin{array}{l}\text { Usulan Baru } \\
\text { mulai Volume } 13 \\
\text { Nomor } 1 \text { Tahun } \\
2018\end{array}$ \\
\hline & 123 & $\begin{array}{l}\text { KESMAS } \\
\text { UWIGAMA: Jurnal } \\
\text { Kesehatan } \\
\text { Masyarakat }\end{array}$ & 24775819 & $\begin{array}{l}\text { Universitas } \\
\text { Widya Gama } \\
\text { Mahakam } \\
\text { Samarinda }\end{array}$ & $\begin{array}{l}\text { Usulan Baru } \\
\text { mulai Volume } 4 \\
\text { Nomor } 1 \text { Tahun } \\
2018\end{array}$ \\
\hline & 124 & $\begin{array}{l}\text { Kiryoku : Jurnal } \\
\text { Studi Kejepangan }\end{array}$ & 25810960 & $\begin{array}{l}\text { Universitas } \\
\text { Diponegoro }\end{array}$ & $\begin{array}{l}\text { Usulan Baru } \\
\text { mulai Volume } 2 \\
\text { Nomor } 1 \text { Tahun } \\
2018\end{array}$ \\
\hline & 125 & $\begin{array}{l}\text { Komputasi: Jurnal } \\
\text { Ilmiah Ilmu } \\
\text { Komputer dan } \\
\text { Matematika }\end{array}$ & 26543990 & $\begin{array}{l}\text { Universitas } \\
\text { Pakuan }\end{array}$ & $\begin{array}{l}\text { Usulan Baru } \\
\text { mulai Volume } 15 \\
\text { Nomor } 2 \text { Tahun } \\
2018\end{array}$ \\
\hline & 126 & Law and Justice & 25498282 & $\begin{array}{l}\text { Fakultas Hukum } \\
\text { Universitas } \\
\text { Muhammadiyah } \\
\text { Surakarta }\end{array}$ & $\begin{array}{l}\text { Reakreditasi Naik } \\
\text { Peringkat dari } \\
\text { Peringkat } 6 \mathrm{ke} \\
\text { Peringkat } 4 \text { mulai } \\
\text { Volume } 4 \text { Nomor } \\
2 \text { Tahun } 2019 \\
\end{array}$ \\
\hline
\end{tabular}




\begin{tabular}{|c|c|c|c|c|c|}
\hline \begin{tabular}{|l|} 
Peringkat \\
\end{tabular} & No. & Nama Jurnal & E-ISSN & Penerbit & Keterangan \\
\hline & 127 & $\begin{array}{l}\text { Lex Librum: Jurnal } \\
\text { Ilmu Hukum }\end{array}$ & 26219867 & $\begin{array}{l}\text { Sekolah Tinggi } \\
\text { Ilmu Hukum } \\
\text { Sumpah Pemuda }\end{array}$ & $\begin{array}{l}\text { Reakreditasi Naik } \\
\text { Peringkat dari } \\
\text { Peringkat } 5 \text { ke } \\
\text { Peringkat } 4 \text { mulai } \\
\text { Volume } 6 \text { Nomor } \\
1 \text { Tahun } 2019\end{array}$ \\
\hline & 128 & $\begin{array}{l}\text { Linguista: Jurnal } \\
\text { Ilmiah Bahasa, } \\
\text { Sastra, dan } \\
\text { Pembelajarannya }\end{array}$ & 25798944 & $\begin{array}{l}\text { Universitas PGRI } \\
\text { Madiun }\end{array}$ & $\begin{array}{l}\text { Usulan Baru } \\
\text { mulai Volume } 2 \\
\text { Nomor } 1 \text { Tahun } \\
2018\end{array}$ \\
\hline & 129 & $\begin{array}{l}\text { Lingusitic, English } \\
\text { Education and Art } \\
\text { (LEEA) Journal }\end{array}$ & 25973819 & $\begin{array}{l}\text { Institut } \\
\text { Penelitian } \\
\text { Matematika, } \\
\text { Komputer, } \\
\text { Keperawatan, } \\
\text { Pendidikan, dan } \\
\text { Ekonomi } \\
\text { (IPM2KPE) } \\
\end{array}$ & $\begin{array}{l}\text { Reakreditasi } \\
\text { Tetap di } \\
\text { Peringkat } 4 \text { mulai } \\
\text { Volume } 3 \text { Nomor } \\
1 \text { Tahun } 2019\end{array}$ \\
\hline & 130 & $\begin{array}{l}\text { Living Islam: Journal } \\
\text { of Islamic } \\
\text { Discourses }\end{array}$ & 26216590 & $\begin{array}{l}\text { Universitas Islam } \\
\text { Negeri Sunan } \\
\text { Kalijaga }\end{array}$ & $\begin{array}{l}\text { Usulan Baru } \\
\text { mulai Volume } 1 \\
\text { Nomor } 2 \text { Tahun } \\
2018\end{array}$ \\
\hline & 131 & $\begin{array}{l}\text { Malahayati } \\
\text { International } \\
\text { Journal of Nursing } \\
\text { and Health Science }\end{array}$ & 26214083 & $\begin{array}{l}\text { Universitas } \\
\text { Malahayati }\end{array}$ & $\begin{array}{l}\text { Usulan Baru } \\
\text { mulai Volume } 1 \\
\text { Nomor } 1 \text { Tahun } \\
2018\end{array}$ \\
\hline & 132 & $\begin{array}{l}\text { Matappa: Jurnal } \\
\text { Pengabdian Kepada } \\
\text { Masyarakat }\end{array}$ & 26146673 & $\begin{array}{l}\text { STKIP Andi } \\
\text { Matappa } \\
\text { Pangkep }\end{array}$ & $\begin{array}{l}\text { Usulan Baru } \\
\text { mulai Volume } 1 \\
\text { Nomor } 1 \text { Tahun } \\
2018\end{array}$ \\
\hline & 133 & $\begin{array}{l}\text { Modeling: Jurnal } \\
\text { Prodi PGMI }\end{array}$ & $2477667 X$ & $\begin{array}{l}\text { Prodi PGMI } \\
\text { STITNU Al } \\
\text { Hikmah } \\
\text { Mojokerto }\end{array}$ & $\begin{array}{l}\text { Reakreditasi } \\
\text { Tetap di } \\
\text { Peringkat } 4 \text { mulai } \\
\text { Volume } 6 \text { Nomor } \\
2 \text { Tahun } 2019\end{array}$ \\
\hline & 134 & $\begin{array}{l}\text { MPI (Media } \\
\text { Pharmaceutica } \\
\text { Indonesiana) }\end{array}$ & 25279017 & $\begin{array}{l}\text { Fakultas Farmasi } \\
\text { Universitas } \\
\text { Surabaya }\end{array}$ & $\begin{array}{l}\text { Reakreditasi } \\
\text { Tetap di } \\
\text { Peringkat } 4 \text { mulai } \\
\text { Volume } 2 \text { Nomor } \\
4 \text { Tahun } 2019\end{array}$ \\
\hline & 135 & $\begin{array}{l}\text { Mulawarman Law } \\
\text { Review }\end{array}$ & 25273477 & $\begin{array}{l}\text { Fakultas Hukum } \\
\text { Universitas } \\
\text { Mulawarman }\end{array}$ & $\begin{array}{l}\text { Usulan Baru } \\
\text { mulai Volume } 3 \\
\text { Nomor } 1 \text { Tahun } \\
2018\end{array}$ \\
\hline & 136 & $\begin{array}{l}\text { Nation State: } \\
\text { Journal of } \\
\text { International Studies } \\
\text { (NSJIS) }\end{array}$ & $2621735 \mathrm{X}$ & $\begin{array}{l}\text { Fakultas } \\
\text { Ekonomi dan } \\
\text { Ilmu Sosial } \\
\text { Universitas } \\
\text { AMIKOM } \\
\text { Yogyakarta } \\
\end{array}$ & $\begin{array}{l}\text { Usulan Baru } \\
\text { mulai Volume } 1 \\
\text { Nomor } 1 \text { Tahun } \\
2018\end{array}$ \\
\hline
\end{tabular}




\begin{tabular}{|c|c|c|c|c|c|}
\hline \begin{tabular}{|l|} 
Peringkat \\
\end{tabular} & No. & Nama Jurnal & E-ISSN & Penerbit & Keterangan \\
\hline & 137 & $\begin{array}{l}\text { Nisbah: Jurnal } \\
\text { Perbankan Syariah }\end{array}$ & 25286633 & $\begin{array}{l}\text { Program Studi } \\
\text { Perbankan } \\
\text { Syariah Fakultas } \\
\text { Ekonomi Islam } \\
\text { Universitas } \\
\text { Djuanda Bogor }\end{array}$ & $\begin{array}{l}\text { Reakreditasi Naik } \\
\text { Peringkat dari } \\
\text { Peringkat } 5 \text { ke } \\
\text { Peringkat } 4 \text { mulai } \\
\text { Volume } 4 \text { Nomor } \\
1 \text { Tahun } 2018\end{array}$ \\
\hline & 138 & $\begin{array}{l}\text { Nun: Jurnal Studi } \\
\text { Alquran dan Tafsir } \\
\text { di Nusantara }\end{array}$ & 25812254 & $\begin{array}{l}\text { Asosiasi Ilmu } \\
\text { Alqur'an dan } \\
\text { Tafsir se- } \\
\text { Indonesia }\end{array}$ & $\begin{array}{l}\text { Usulan Baru } \\
\text { mulai Volume } 4 \\
\text { Nomor } 1 \text { Tahun } \\
2018\end{array}$ \\
\hline & 139 & Paedagogie & 26217171 & $\begin{array}{l}\text { Universitas } \\
\text { Muhammadiyah } \\
\text { Magelang }\end{array}$ & $\begin{array}{l}\text { Usulan Baru } \\
\text { mulai Volume } 13 \\
\text { Nomor } 1 \text { Tahun } \\
2018\end{array}$ \\
\hline & 140 & $\begin{array}{l}\text { PARETO: Jurnal } \\
\text { Ekonomi dan } \\
\text { Kebijakan Publik }\end{array}$ & 26203456 & $\begin{array}{l}\text { Fakultas } \\
\text { Ekonomi } \\
\text { Universitas Prof. } \\
\text { Dr. Hazairin, SH }\end{array}$ & $\begin{array}{l}\text { Usulan Baru } \\
\text { mulai Volume } 1 \\
\text { Nomor } 1 \text { Tahun } \\
2018\end{array}$ \\
\hline & 141 & $\begin{array}{l}\text { Pastura: Journal of } \\
\text { Tropical Forage } \\
\text { Science }\end{array}$ & 25498444 & $\begin{array}{l}\text { Universitas } \\
\text { Udayana }\end{array}$ & $\begin{array}{l}\text { Usulan Baru } \\
\text { mulai Volume } 7 \\
\text { Nomor } 2 \text { Tahun } \\
2018\end{array}$ \\
\hline & 142 & $\begin{array}{l}\text { Pasundan Food } \\
\text { Technology Journal } \\
\text { (PFTJ) }\end{array}$ & 26151405 & $\begin{array}{l}\text { Universitas } \\
\text { Pasundan }\end{array}$ & $\begin{array}{l}\text { Usulan Baru } \\
\text { mulai Volume } 5 \\
\text { Nomor } 1 \text { Tahun } \\
2018\end{array}$ \\
\hline & 143 & $\begin{array}{l}\text { Permana: Jurnal } \\
\text { Perpajakan, } \\
\text { Manajemen, dan } \\
\text { Akuntansi }\end{array}$ & $2685600 X$ & $\begin{array}{l}\text { Universitas } \\
\text { Pancasakti Tegal }\end{array}$ & $\begin{array}{l}\text { Usulan Baru } \\
\text { mulai Volume } 10 \\
\text { Nomor } 1 \text { Tahun } \\
2018\end{array}$ \\
\hline & 144 & $\begin{array}{l}\text { Rabit: Jurnal } \\
\text { Teknologi dan } \\
\text { Sistem Informasi } \\
\text { Univrab }\end{array}$ & $2502891 X$ & $\begin{array}{l}\text { LPPM Universitas } \\
\text { Abdurrab }\end{array}$ & $\begin{array}{l}\text { Reakreditasi Naik } \\
\text { Peringkat dari } \\
\text { Peringkat } 5 \mathrm{ke} \\
\text { Peringkat } 4 \text { mulai } \\
\text { Volume } 5 \text { Nomor } \\
1 \text { Tahun } 2020\end{array}$ \\
\hline & 145 & $\begin{array}{l}\text { Samakia: Jurnal } \\
\text { Ilmu Perikanan }\end{array}$ & 25032283 & $\begin{array}{l}\text { Fakultas Sains \& } \\
\text { Teknologi, } \\
\text { Universitas } \\
\text { Ibrahimy }\end{array}$ & $\begin{array}{l}\text { Reakreditasi Naik } \\
\text { Peringkat dari } \\
\text { Peringkat } 5 \text { ke } \\
\text { Peringkat } 4 \text { mulai } \\
\text { Volume } 9 \text { Nomor } \\
1 \text { Tahun } 2018\end{array}$ \\
\hline & 146 & $\begin{array}{l}\text { SeBaSa: Jurnal } \\
\text { Pendidikan Bahasa } \\
\text { dan Sastra } \\
\text { Indonesia }\end{array}$ & 26210851 & $\begin{array}{l}\text { Universitas } \\
\text { Hamzanwadi }\end{array}$ & $\begin{array}{l}\text { Usulan Baru } \\
\text { mulai Volume } 1 \\
\text { Nomor } 1 \text { Tahun } \\
2018\end{array}$ \\
\hline
\end{tabular}




\begin{tabular}{|c|c|c|c|c|c|}
\hline \begin{tabular}{|l|} 
Peringkat \\
\end{tabular} & No. & Nama Jurnal & E-ISSN & Penerbit & Keterangan \\
\hline & 147 & $\begin{array}{l}\text { Siklus: Journal } \\
\text { Research Midwifery } \\
\text { Politeknik Tegal }\end{array}$ & 25495054 & $\begin{array}{l}\text { Pusat Penelitian } \\
\text { dan Pengabdian } \\
\text { Masyarakat } \\
\text { (P3M) Politeknik } \\
\text { Harapan } \\
\text { Bersama }\end{array}$ & $\begin{array}{l}\text { Reakreditasi } \\
\text { Tetap di } \\
\text { Peringkat } 4 \text { mulai } \\
\text { Volume } 9 \text { Nomor } \\
1 \text { Tahun } 2020\end{array}$ \\
\hline & 148 & Simbiosa & 25986007 & $\begin{array}{l}\text { Universitas Riau } \\
\text { Kepulauan }\end{array}$ & $\begin{array}{l}\text { Reakreditasi } \\
\text { Tetap di } \\
\text { Peringkat } 4 \text { mulai } \\
\text { Volume } 8 \text { Nomor } \\
2 \text { Tahun } 2019\end{array}$ \\
\hline & 149 & Sirok Bastra & 26212013 & $\begin{array}{l}\text { Kantor Bahasa } \\
\text { Kepulauan } \\
\text { Bangka Belitung }\end{array}$ & $\begin{array}{l}\text { Usulan Baru } \\
\text { mulai Volume } 6 \\
\text { Nomor } 2 \text { Tahun } \\
2018\end{array}$ \\
\hline & 150 & $\begin{array}{l}\text { Smart Medical } \\
\text { Journal }\end{array}$ & 2621091 & $\begin{array}{l}\text { Universitas } \\
\text { Sebelas Maret }\end{array}$ & $\begin{array}{l}\text { Usulan Baru } \\
\text { mulai Volume } 1 \\
\text { Nomor } 1 \text { Tahun } \\
2018\end{array}$ \\
\hline & 151 & $\begin{array}{l}\text { Socia: Jurnal Ilmu- } \\
\text { Ilmu Sosial }\end{array}$ & 25499475 & $\begin{array}{l}\text { Fakultas Ilmu } \\
\text { Sosial } \\
\text { Universitas } \\
\text { Negeri } \\
\text { Yogyakarta }\end{array}$ & $\begin{array}{l}\text { Reakreditasi Naik } \\
\text { Peringkat dari } \\
\text { Peringkat } 5 \text { ke } \\
\text { Peringkat } 4 \text { mulai } \\
\text { Volume } 16 \\
\text { Nomor } 2 \text { Tahun } \\
2019\end{array}$ \\
\hline & 152 & $\begin{array}{l}\text { Socius (Pendidikan } \\
\text { dan Pembelajaran } \\
\text { Ilmu Pengetahuan } \\
\text { Sosial) }\end{array}$ & $2089967 X$ & $\begin{array}{l}\text { Universitas } \\
\text { Lambung } \\
\text { Mangkurat }\end{array}$ & $\begin{array}{l}\text { Usulan Baru } \\
\text { mulai Volume } 7 \\
\text { Nomor } 1 \text { Tahun } \\
2018\end{array}$ \\
\hline & 153 & $\begin{array}{l}\text { SPEJ (Science and } \\
\text { Physics Education } \\
\text { Journal) }\end{array}$ & 25982567 & $\begin{array}{l}\text { Institut } \\
\text { Penelitian } \\
\text { Matematika, } \\
\text { Komputer, } \\
\text { Keperawatan, } \\
\text { Pendidikan, dan } \\
\text { Ekonomi } \\
\text { (IPM2KPE) } \\
\end{array}$ & $\begin{array}{l}\text { Reakreditasi } \\
\text { Tetap di } \\
\text { Peringkat } 4 \text { mulai } \\
\text { Volume } 3 \text { Nomor } \\
1 \text { Tahun } 2019\end{array}$ \\
\hline & 154 & $\begin{array}{l}\text { Sutasoma : Jurnal } \\
\text { Sastra Jawa }\end{array}$ & 26865408 & $\begin{array}{l}\text { Jurusan Bahasa } \\
\text { dan Sastra Jawa, } \\
\text { Fakultas Bahasa } \\
\text { dan Seni, } \\
\text { Universitas } \\
\text { Negeri Semarang }\end{array}$ & $\begin{array}{l}\text { Usulan Baru } \\
\text { mulai Volume } 6 \\
\text { Nomor } 1 \text { Tahun } \\
2018\end{array}$ \\
\hline & 155 & $\begin{array}{l}\text { Tekinfo (Jurnal } \\
\text { Ilmiah Teknik } \\
\text { Industri dan } \\
\text { Informasi) }\end{array}$ & 23031867 & $\begin{array}{l}\text { Program Studi S1 } \\
\text { Teknik Industri - } \\
\text { Universitas Setia } \\
\text { Budi }\end{array}$ & $\begin{array}{l}\text { Usulan Baru } \\
\text { mulai Volume } 6 \\
\text { Nomor } 2 \text { Tahun } \\
2018\end{array}$ \\
\hline
\end{tabular}




\begin{tabular}{|c|c|c|c|c|c|}
\hline \begin{tabular}{|l|} 
Peringkat \\
\end{tabular} & No. & Nama Jurnal & E-ISSN & Penerbit & Keterangan \\
\hline & 156 & $\begin{array}{l}\text { Teknika: Jurnal } \\
\text { Sains dan Teknologi }\end{array}$ & 26544113 & $\begin{array}{l}\text { Fakultas Teknik } \\
\text { Universitas } \\
\text { Sultan Ageng } \\
\text { Tirtayasa }\end{array}$ & $\begin{array}{l}\text { Reakreditasi Naik } \\
\text { Peringkat dari } \\
\text { Peringkat } 5 \text { ke } \\
\text { Peringkat } 4 \text { mulai } \\
\text { Volume } 15 \\
\text { Nomor } 2 \text { Tahun } \\
2019\end{array}$ \\
\hline & 157 & Teknodika & 26566621 & $\begin{array}{l}\text { Program Studi } \\
\text { Magister } \\
\text { Teknologi } \\
\text { Pendidikan } \\
\text { Universitas } \\
\text { Sebelas Maret }\end{array}$ & $\begin{array}{l}\text { Usulan Baru } \\
\text { mulai Volume } 16 \\
\text { Nomor } 1 \text { Tahun } \\
2018\end{array}$ \\
\hline & 158 & $\begin{array}{l}\text { The Indonesian } \\
\text { Journal of Health } \\
\text { Science }\end{array}$ & 24769614 & $\begin{array}{l}\text { Universitas } \\
\text { Muhammadiyah } \\
\text { Jember }\end{array}$ & $\begin{array}{l}\text { Reakreditasi Naik } \\
\text { Peringkat dari } \\
\text { Peringkat } 5 \text { ke } \\
\text { Peringkat } 4 \text { mulai } \\
\text { Volume } 10 \\
\text { Nomor } 1 \text { Tahun } \\
2018\end{array}$ \\
\hline & 159 & $\begin{array}{l}\text { The International } \\
\text { Journal of Applied } \\
\text { Business }\end{array}$ & 25990705 & $\begin{array}{l}\text { Universitas } \\
\text { Airlangga }\end{array}$ & $\begin{array}{l}\text { Usulan Baru } \\
\text { mulai Volume } 2 \\
\text { Nomor } 1 \text { Tahun } \\
2018\end{array}$ \\
\hline & 160 & $\begin{array}{l}\text { The International } \\
\text { Journal of Business } \\
\text { Review (The Jobs } \\
\text { Review) }\end{array}$ & $2621413 X$ & $\begin{array}{l}\text { Universitas } \\
\text { Pendidikan } \\
\text { Indonesia }\end{array}$ & $\begin{array}{l}\text { Usulan Baru } \\
\text { mulai Volume } 1 \\
\text { Nomor } 1 \text { Tahun } \\
2018\end{array}$ \\
\hline & 161 & $\begin{array}{l}\text { Tropical Wetland } \\
\text { Journal }\end{array}$ & $2654279 X$ & $\begin{array}{l}\text { Program } \\
\text { Pascasarjana, } \\
\text { Universitas } \\
\text { Lambung } \\
\text { Mangkurat }\end{array}$ & $\begin{array}{l}\text { Usulan Baru } \\
\text { mulai Volume } 4 \\
\text { Nomor } 1 \text { Tahun } \\
2018\end{array}$ \\
\hline & 162 & $\begin{array}{l}\text { Undas: Jurnal Hasil } \\
\text { Penelitian Bahasa } \\
\text { dan Sastra }\end{array}$ & 18584470 & $\begin{array}{l}\text { Balai Bahasa } \\
\text { Kalimantan } \\
\text { Selatan }\end{array}$ & $\begin{array}{l}\text { Usulan Baru } \\
\text { mulai Volume } 14 \\
\text { Nomor } 1 \text { Tahun } \\
2018\end{array}$ \\
\hline & 163 & $\begin{array}{l}\text { Warmadewa } \\
\text { Medical Journal } \\
\text { (WMJ) }\end{array}$ & 25799010 & $\begin{array}{l}\text { Universitas } \\
\text { Warmadewa }\end{array}$ & $\begin{array}{l}\text { Reakreditasi } \\
\text { Tetap di } \\
\text { Peringkat } 4 \text { mulai } \\
\text { Volume } 4 \text { Nomor } \\
3 \text { Tahun } 2019\end{array}$ \\
\hline & 164 & $\begin{array}{l}\text { World Nutrition } \\
\text { Journal }\end{array}$ & 25807013 & $\begin{array}{l}\text { Perhimpunan } \\
\text { Nutrisi Indonesia }\end{array}$ & $\begin{array}{l}\text { Usulan Baru } \\
\text { mulai Volume } 2 \\
\text { Nomor } 1 \text { Tahun } \\
2018\end{array}$ \\
\hline
\end{tabular}




\begin{tabular}{|c|c|c|c|c|c|}
\hline \begin{tabular}{|l|} 
Peringkat \\
\end{tabular} & No. & Nama Jurnal & E-ISSN & Penerbit & Keterangan \\
\hline \multirow[t]{10}{*}{5} & 1 & $\begin{array}{l}\text { Agro Bali: } \\
\text { Agricultural Journal }\end{array}$ & $2655853 X$ & $\begin{array}{l}\text { Universitas Panji } \\
\text { Sakti }\end{array}$ & $\begin{array}{l}\text { Usulan Baru } \\
\text { mulai Volume } 1 \\
\text { Nomor } 1 \text { Tahun } \\
2018\end{array}$ \\
\hline & 2 & $\begin{array}{l}\text { Agroekoteknologi } \\
\text { Tropika Lembab }\end{array}$ & $2621394 X$ & $\begin{array}{l}\text { Jurusan } \\
\text { Agroekoteknologi } \\
\text { Fakultas } \\
\text { Pertanian } \\
\text { Universitas } \\
\text { Mulawarman }\end{array}$ & $\begin{array}{l}\text { Usulan Baru } \\
\text { mulai Volume } 1 \\
\text { Nomor } 1 \text { Tahun } \\
2018\end{array}$ \\
\hline & 3 & $\begin{array}{l}\text { Agroindustrial } \\
\text { Technology Journal }\end{array}$ & 25989480 & $\begin{array}{l}\text { Universitas } \\
\text { Darussalam } \\
\text { Gontor }\end{array}$ & $\begin{array}{l}\text { Usulan Baru } \\
\text { mulai Volume } 2 \\
\text { Nomor } 1 \text { Tahun } \\
2018\end{array}$ \\
\hline & 4 & $\begin{array}{l}\text { Al Qodiri: Jurnal } \\
\text { Pendidikan, Sosial } \\
\text { dan Keagamaan }\end{array}$ & 25988735 & $\begin{array}{l}\text { P3M Sekolah } \\
\text { Tinggi Agama } \\
\text { Islam STAI Al- } \\
\text { Qodiri }\end{array}$ & $\begin{array}{l}\text { Reakreditasi Naik } \\
\text { Peringkat dari } \\
\text { Peringkat } 6 \text { ke } \\
\text { Peringkat } 5 \text { mulai } \\
\text { Volume } 17 \\
\text { Nomor } 2 \text { Tahun } \\
2019\end{array}$ \\
\hline & 5 & $\begin{array}{l}\text { Al-Bayan: Jurnal } \\
\text { Ilmu Al-Qur'an dan } \\
\text { Hadist }\end{array}$ & 26152568 & $\begin{array}{l}\text { Sekolah Tinggi } \\
\text { Ilmu Al-Qur'an } \\
\text { Wali Songo } \\
\text { Situbondo }\end{array}$ & $\begin{array}{l}\text { Usulan Baru } \\
\text { mulai Volume } 1 \\
\text { Nomor } 1 \text { Tahun } \\
2018\end{array}$ \\
\hline & 6 & $\begin{array}{l}\text { Al-Fikr: Jurnal } \\
\text { Pendidikan Islam }\end{array}$ & 27163717 & $\begin{array}{l}\text { Sekolah Tinggi } \\
\text { Agama Islam } \\
\text { Negeri Sorong }\end{array}$ & $\begin{array}{l}\text { Usulan Baru } \\
\text { mulai Volume } 4 \\
\text { Nomor } 1 \text { Tahun } \\
2018\end{array}$ \\
\hline & 7 & $\begin{array}{l}\text { Al-Idaroh: Jurnal } \\
\text { Studi Manajemen } \\
\text { Pendidikan Islam }\end{array}$ & 25793683 & $\begin{array}{l}\text { LP3M Sekolah } \\
\text { Tinggi Ilmu } \\
\text { Tarbiyah Al- } \\
\text { Urwatul Wutsqo } \\
\text { Jombang } \\
\end{array}$ & $\begin{array}{l}\text { Usulan Baru } \\
\text { mulai Volume } 2 \\
\text { Nomor } 1 \text { Tahun } \\
2018\end{array}$ \\
\hline & 8 & $\begin{array}{l}\text { Al-Iktisab: Journal } \\
\text { of Islamic Economic } \\
\text { Law }\end{array}$ & $2615661 X$ & $\begin{array}{l}\text { Universitas } \\
\text { Darussalam } \\
\text { Gontor }\end{array}$ & $\begin{array}{l}\text { Usulan Baru } \\
\text { mulai Volume } 2 \\
\text { Nomor } 1 \text { Tahun } \\
2018\end{array}$ \\
\hline & $\overline{9}$ & Al-Mabsut & $2502213 \mathrm{X}$ & $\begin{array}{l}\text { Institut Agama } \\
\text { Islam Ngawi }\end{array}$ & $\begin{array}{l}\text { Usulan Baru } \\
\text { mulai Volume } 12 \\
\text { Nomor } 1 \text { Tahun } \\
2018\end{array}$ \\
\hline & 10 & $\begin{array}{l}\text { Al-Manar: Jurnal } \\
\text { Komunikasi dan } \\
\text { Pendidikan Islam }\end{array}$ & 26158779 & $\begin{array}{l}\text { Sekolah Tinggi } \\
\text { Agama Islam } \\
\text { Masjid Syuhada } \\
\text { (STAIMS) } \\
\text { Yogyakarta }\end{array}$ & $\begin{array}{l}\text { Usulan Baru } \\
\text { mulai Volume } 7 \\
\text { Nomor } 1 \text { Tahun } \\
2018\end{array}$ \\
\hline
\end{tabular}




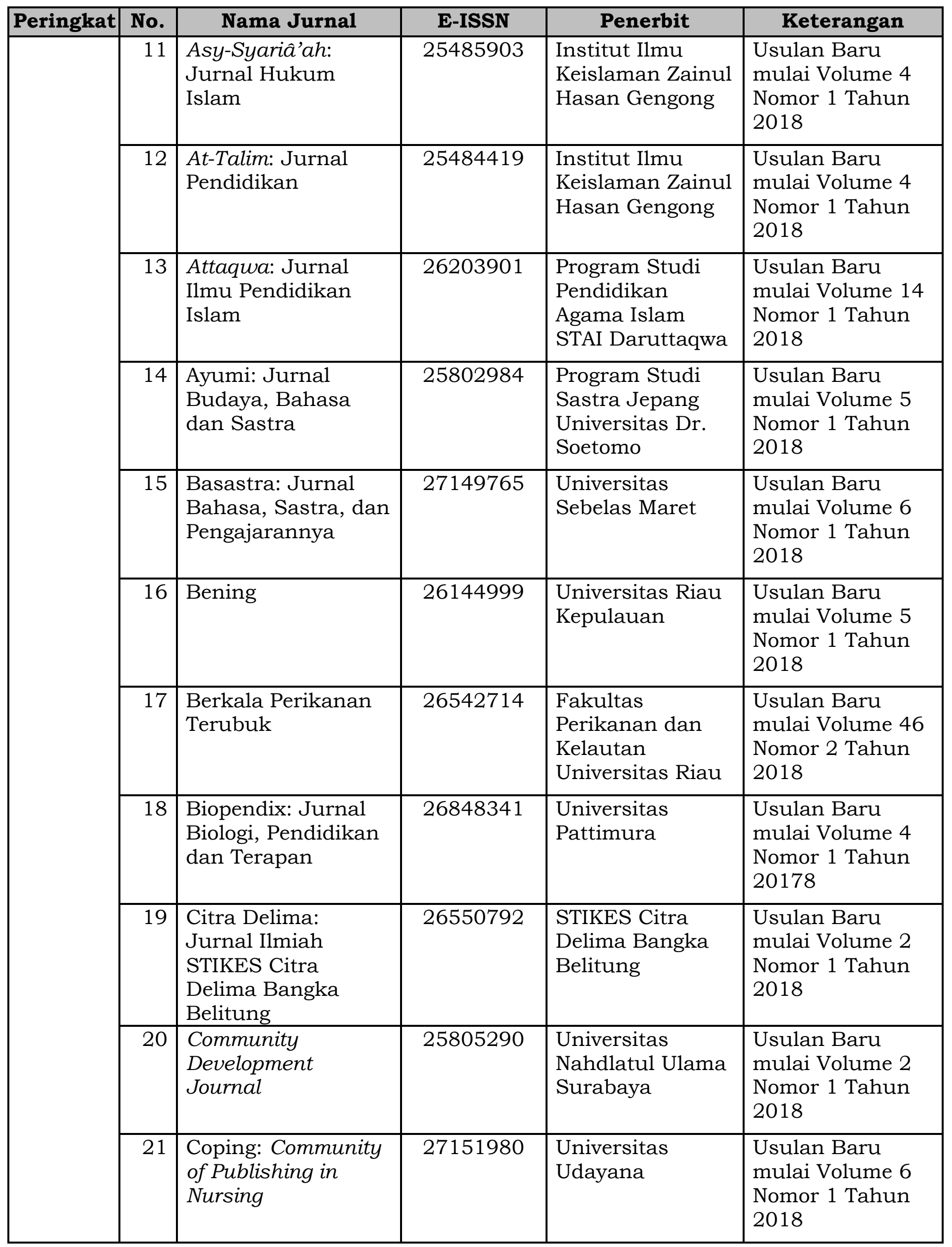




\begin{tabular}{|c|c|c|c|c|c|}
\hline Peringkat & No. & Nama Jurnal & E-ISSN & Penerbit & Keterangan \\
\hline & 22 & $\begin{array}{l}\text { Cyber Security dan } \\
\text { Forensik Digital } \\
\text { (CSFD) }\end{array}$ & 26158442 & $\begin{array}{l}\text { Universitas Islam } \\
\text { Negeri Sunan } \\
\text { Kalijaga }\end{array}$ & $\begin{array}{l}\text { Usulan Baru } \\
\text { mulai Volume } 1 \\
\text { Nomor } 1 \text { Tahun } \\
2018\end{array}$ \\
\hline & 23 & DIALEKTIKA & $2685791 X$ & $\begin{array}{l}\text { Institut Agama } \\
\text { Islam Negeri } \\
\text { Ambon }\end{array}$ & $\begin{array}{l}\text { Usulan Baru } \\
\text { mulai Volume } 11 \\
\text { Nomor } 1 \text { Tahun } \\
2018\end{array}$ \\
\hline & 24 & $\begin{array}{l}\text { Dialektika: Jurnal } \\
\text { Ekonomi dan Ilmu } \\
\text { Sosial }\end{array}$ & $2598781 X$ & $\begin{array}{l}\text { Universitas Islam } \\
\text { Raden Rahmat } \\
\text { Malang }\end{array}$ & $\begin{array}{l}\text { Usulan Baru } \\
\text { mulai Volume } 3 \\
\text { Nomor } 1 \text { Tahun } \\
2018\end{array}$ \\
\hline & 25 & $\begin{array}{l}\text { Didaktika: Jurnal } \\
\text { Pendidikan Sekolah } \\
\text { Dasar }\end{array}$ & 27158128 & $\begin{array}{l}\text { Universitas } \\
\text { Negeri } \\
\text { Yogyakarta }\end{array}$ & $\begin{array}{l}\text { Usulan Baru } \\
\text { mulai Volume } 1 \\
\text { Nomor } 1 \text { Tahun } \\
2018\end{array}$ \\
\hline & 26 & $\begin{array}{l}\text { DIKDAS MATAPPA: } \\
\text { Jurnal Pendidikan } \\
\text { Dasar }\end{array}$ & 26206307 & $\begin{array}{l}\text { STKIP Andi } \\
\text { Matappa } \\
\text { Pangkep }\end{array}$ & $\begin{array}{l}\text { Usulan Baru } \\
\text { mulai Volume } 1 \\
\text { Nomor } 1 \text { Tahun } \\
2018\end{array}$ \\
\hline & 27 & Jurnal Dimensi & 25990004 & $\begin{array}{l}\text { Universitas Riau } \\
\text { Kepulauan } \\
\text { Batam }\end{array}$ & $\begin{array}{l}\text { Usulan Baru } \\
\text { mulai Volume } 7 \\
\text { Nomor } 1 \text { Tahun } \\
2018\end{array}$ \\
\hline & 28 & $\begin{array}{l}\text { Dinamika Global: } \\
\text { Jurnal Ilmu } \\
\text { Hubungan } \\
\text { Internasional }\end{array}$ & 26849399 & $\begin{array}{l}\text { Universitas } \\
\text { Jenderal Achmad } \\
\text { Yani }\end{array}$ & $\begin{array}{l}\text { Usulan Baru } \\
\text { mulai Volume } 3 \\
\text { Nomor } 1 \text { Tahun } \\
2018\end{array}$ \\
\hline & 29 & $\begin{array}{l}\text { E-Bisnis: Jurnal } \\
\text { Ilmiah Ekonomi dan } \\
\text { Bisnis }\end{array}$ & 26148870 & $\begin{array}{l}\text { Sekolah Tinggi } \\
\text { Elektronika dan } \\
\text { Komputer }\end{array}$ & $\begin{array}{l}\text { Usulan Baru } \\
\text { mulai Volume } 11 \\
\text { Nomor } 1 \text { Tahun } \\
2018\end{array}$ \\
\hline & 30 & $\begin{array}{l}\text { Economos: Jurnal } \\
\text { Ekonomi dan Bisnis }\end{array}$ & $2655321 X$ & $\begin{array}{l}\text { Universitas } \\
\text { Muhammadiyah } \\
\text { Parepare }\end{array}$ & $\begin{array}{l}\text { Usulan Baru } \\
\text { mulai Volume } 1 \\
\text { Nomor } 2 \text { Tahun } \\
2018\end{array}$ \\
\hline & 31 & $\begin{array}{l}\text { Edugama: Jurnal } \\
\text { Kependidikan dan } \\
\text { Sosial Keagamaan }\end{array}$ & 26140217 & $\begin{array}{l}\text { LP2M IAIN } \\
\text { Syaikh } \\
\text { Abdurrahman } \\
\text { Siddik Bangka } \\
\text { Belitung }\end{array}$ & $\begin{array}{l}\text { Usulan Baru } \\
\text { mulai Volume } 4 \\
\text { Nomor } 1 \text { Tahun } \\
2018\end{array}$ \\
\hline & 32 & $\begin{array}{l}\text { Efficient: Indonesian } \\
\text { Journal of } \\
\text { Development } \\
\text { Economics }\end{array}$ & $2655318 X$ & $\begin{array}{l}\text { Universitas } \\
\text { Negeri Semarang }\end{array}$ & $\begin{array}{l}\text { Usulan Baru } \\
\text { mulai Volume } 1 \\
\text { Nomor } 2 \text { Tahun } \\
2018\end{array}$ \\
\hline
\end{tabular}




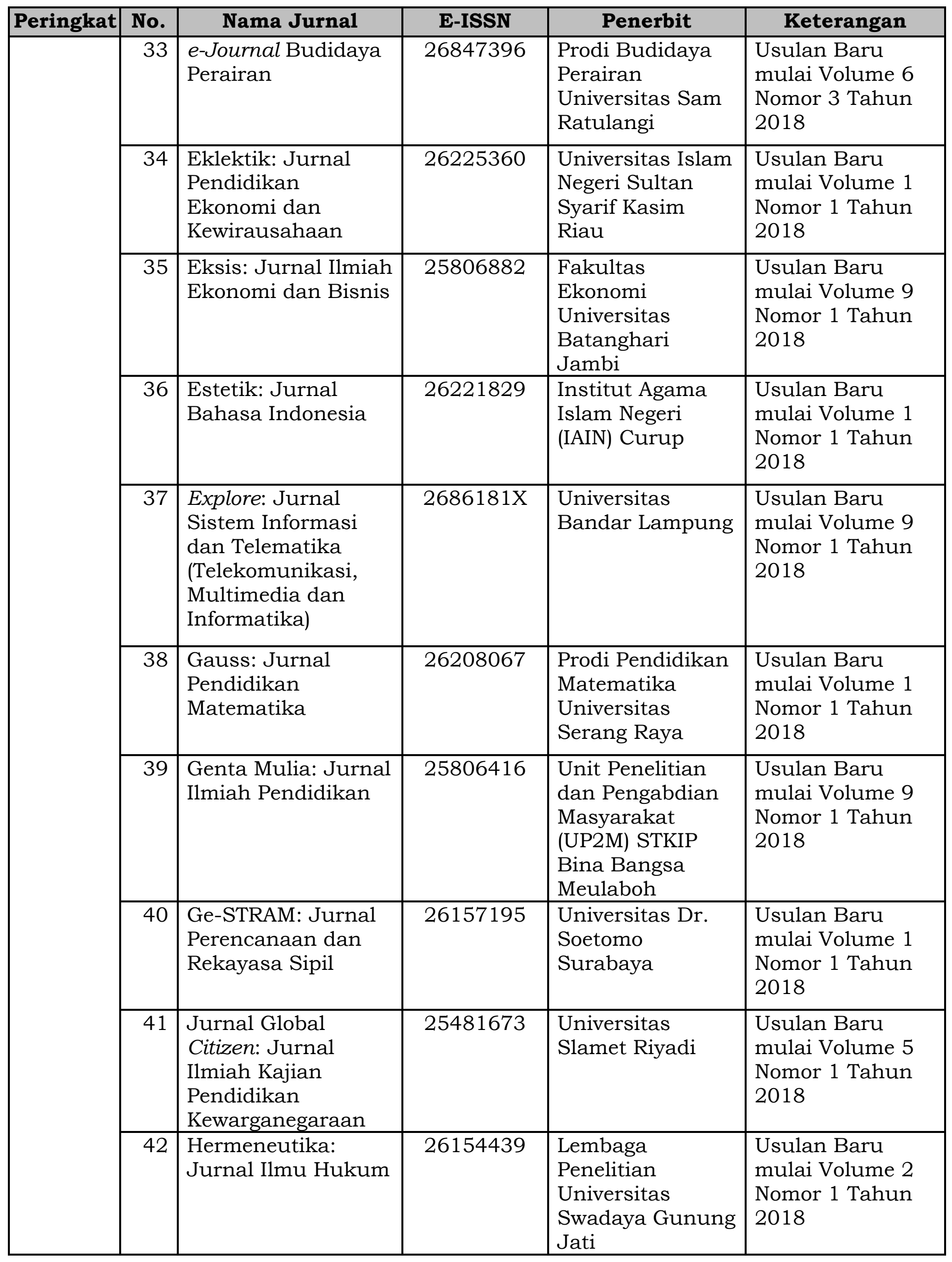

43. Humanika ... 


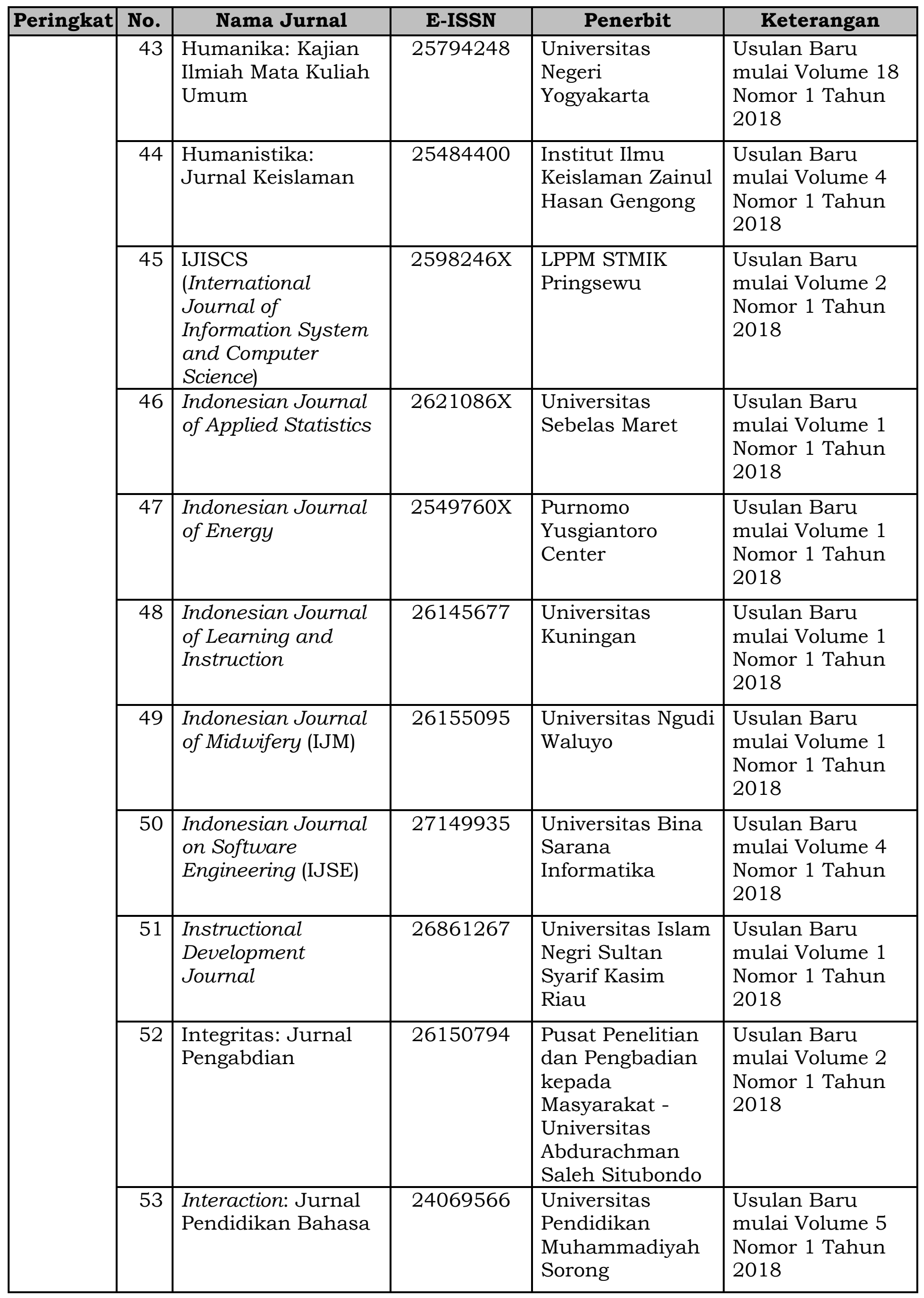

54. Internal ... 


\begin{tabular}{|c|c|c|c|c|c|}
\hline \begin{tabular}{|l|} 
Peringkat \\
\end{tabular} & No. & Nama Jurnal & E-ISSN & Penerbit & Keterangan \\
\hline & 54 & $\begin{array}{l}\text { Internal (Information } \\
\text { System Journal) }\end{array}$ & 26560259 & $\begin{array}{l}\text { Universitas } \\
\text { Masoem }\end{array}$ & $\begin{array}{l}\text { Usulan Baru } \\
\text { mulai Volume } 1 \\
\text { Nomor } 1 \text { Tahun } \\
2018\end{array}$ \\
\hline & 55 & $\begin{array}{l}\text { International } \\
\text { Journal on } \\
\text { Language, Research } \\
\text { and Education } \\
\text { Studies } \\
\end{array}$ & 25806785 & $\begin{array}{l}\text { Fakultas Ilmu } \\
\text { Tarbiyah dan } \\
\text { Keguruan UIN } \\
\text { Sumatera Utara }\end{array}$ & $\begin{array}{l}\text { Usulan Baru } \\
\text { mulai Volume } 2 \\
\text { Nomor } 1 \text { Tahun } \\
2018\end{array}$ \\
\hline & 56 & $\begin{array}{l}\text { IQRO: Journal of } \\
\text { Islamic Education }\end{array}$ & 26223201 & $\begin{array}{l}\text { Prodi Pendidikan } \\
\text { Agama Islam } \\
\text { Institut Agama } \\
\text { Islam Negeri } \\
\text { Palopo } \\
\end{array}$ & $\begin{array}{l}\text { Usulan Baru } \\
\text { mulai Volume } 1 \\
\text { Nomor } 1 \text { Tahun } \\
2018\end{array}$ \\
\hline & 57 & Iqtishodiyah & 25485911 & $\begin{array}{l}\text { Institut Ilmu } \\
\text { Keislaman Zainul } \\
\text { Hasan Gengong }\end{array}$ & $\begin{array}{l}\text { Usulan Baru } \\
\text { mulai Volume } 4 \\
\text { Nomor } 1 \text { Tahun } \\
2018\end{array}$ \\
\hline & 58 & $\begin{array}{l}\text { Islam Transformatif: } \\
\text { Journal of Islamic } \\
\text { Studies }\end{array}$ & 25992171 & $\begin{array}{l}\text { Institut Agama } \\
\text { Islam Negeri } \\
\text { Bukittinggi }\end{array}$ & $\begin{array}{l}\text { Usulan Baru } \\
\text { mulai Volume } 2 \\
\text { Nomor } 1 \text { Tahun } \\
2018\end{array}$ \\
\hline & 59 & $\begin{array}{l}\text { Istighna: Jurnal } \\
\text { Pendidikan dan } \\
\text { Pemikiran Islam }\end{array}$ & 26558459 & $\begin{array}{l}\text { Sekolah Tinggi } \\
\text { ilmu Tarbiyah } \\
\text { Islamic Village }\end{array}$ & $\begin{array}{l}\text { Usulan Baru } \\
\text { mulai Volume } 1 \\
\text { Nomor } 2 \text { Tahun } \\
2018\end{array}$ \\
\hline & 60 & $\begin{array}{l}\text { JAF- Journal of } \\
\text { Accounting and } \\
\text { Finance }\end{array}$ & 25811088 & $\begin{array}{l}\text { Universitas } \\
\text { Telkom }\end{array}$ & $\begin{array}{l}\text { Usulan Baru } \\
\text { mulai Volume } 2 \\
\text { Nomor } 1 \text { Tahun } \\
2018\end{array}$ \\
\hline & 61 & $\begin{array}{l}\text { JAS (Jurnal Agri } \\
\text { Sains) }\end{array}$ & 25810227 & $\begin{array}{l}\text { Universitas } \\
\text { Muara Bungo }\end{array}$ & $\begin{array}{l}\text { Usulan Baru } \\
\text { mulai Volume } 2 \\
\text { Nomor } 1 \text { Tahun } \\
2018\end{array}$ \\
\hline & 62 & $\begin{array}{l}\text { JATI EMAS (Jurnal } \\
\text { Aplikasi Teknik dan } \\
\text { Pengabdian } \\
\text { Masyarakat) }\end{array}$ & 25500821 & $\begin{array}{l}\text { DPD Jawa Timur } \\
\text { Forum Dosen } \\
\text { Indonesia }\end{array}$ & $\begin{array}{l}\text { Usulan Baru } \\
\text { mulai Volume } 2 \\
\text { Nomor } 1 \text { Tahun } \\
2018\end{array}$ \\
\hline & 63 & $\begin{array}{l}\text { JEEMECS (Journal } \\
\text { of Electrical } \\
\text { Engineering, } \\
\text { Mechatronic and } \\
\text { Computer Science) } \\
\end{array}$ & 26144867 & $\begin{array}{l}\text { Universitas } \\
\text { Merdeka Malang }\end{array}$ & $\begin{array}{l}\text { Usulan Baru } \\
\text { mulai Volume } 1 \\
\text { Nomor } 1 \text { Tahun } \\
2018\end{array}$ \\
\hline & 64 & $\begin{array}{l}\text { JIMEK: Jurnal } \\
\text { Ilmiah Mahasiswa } \\
\text { Ekonomi }\end{array}$ & 26212374 & $\begin{array}{l}\text { Fakultas } \\
\text { Ekonomi } \\
\text { Universitas } \\
\text { Kadiri }\end{array}$ & $\begin{array}{l}\text { Usulan Baru } \\
\text { mulai Volume } 1 \\
\text { Nomor } 1 \text { Tahun } \\
2018\end{array}$ \\
\hline
\end{tabular}

65. JISAMAR ... 


\begin{tabular}{|c|c|c|c|c|c|}
\hline Peringkat & No. & Nama Jurnal & E-ISSN & Penerbit & Keterangan \\
\hline & 65 & $\begin{array}{l}\text { JISAMAR (Journal of } \\
\text { Information System, } \\
\text { Applied, } \\
\text { Management, } \\
\text { Accounting and } \\
\text { Research) }\end{array}$ & 25988719 & $\begin{array}{l}\text { Sekolah Tinggi } \\
\text { Manajemen } \\
\text { Informatika dan } \\
\text { Komputer } \\
\text { Jayakarta }\end{array}$ & $\begin{array}{l}\text { Usulan Baru } \\
\text { mulai Volume } 2 \\
\text { Nomor } 1 \text { Tahun } \\
2018\end{array}$ \\
\hline & 66 & $\begin{array}{l}\text { JISIP (Jurnal Ilmu } \\
\text { Sosial dan } \\
\text { Pendidikan) }\end{array}$ & 26566753 & $\begin{array}{l}\text { Lembaga } \\
\text { Penelitian dan } \\
\text { Pendidikan (LPP) } \\
\text { Mandala }\end{array}$ & $\begin{array}{l}\text { Usulan Baru } \\
\text { mulai Volume } 2 \\
\text { Nomor } 1 \text { Tahun } \\
2018\end{array}$ \\
\hline & 67 & $\begin{array}{l}\text { Joined Journal } \\
\text { (Journal of } \\
\text { Informatics } \\
\text { Education) }\end{array}$ & 26208415 & Universitas IVET & $\begin{array}{l}\text { Usulan Baru } \\
\text { mulai Volume } 1 \\
\text { Nomor } 2 \text { Tahun } \\
2018\end{array}$ \\
\hline & 68 & $\begin{array}{l}\text { JOLLT: Journal of } \\
\text { Languages and } \\
\text { Language Teaching' }\end{array}$ & 26211378 & IKIP Mataram & $\begin{array}{l}\text { Reakreditasi } \\
\text { Tetap di } \\
\text { Peringkat } 5 \text { mulai } \\
\text { Volume } 8 \text { Nomor } \\
1 \text { Tahun } 2020 \\
\end{array}$ \\
\hline & 69 & $\begin{array}{l}\text { Journal Civics and } \\
\text { Social Studies }\end{array}$ & 26558963 & $\begin{array}{l}\text { Institut } \\
\text { Pendidikan } \\
\text { Indonesia }\end{array}$ & $\begin{array}{l}\text { Usulan Baru } \\
\text { mulai Volume } 2 \\
\text { Nomor } 1 \text { Tahun } \\
2018\end{array}$ \\
\hline & 70 & $\begin{array}{l}\text { Journal of Applied } \\
\text { Sciences in Travel } \\
\text { and Hospitality }\end{array}$ & 26228319 & $\begin{array}{l}\text { Politeknik Negeri } \\
\text { Bali }\end{array}$ & $\begin{array}{l}\text { Usulan Baru } \\
\text { mulai Volume } 1 \\
\text { Nomor } 3 \text { Tahun } \\
2018\end{array}$ \\
\hline & 71 & $\begin{array}{l}\text { Journal of Music } \\
\text { Science, Technology, } \\
\text { and Industry } \\
\text { (JOMSTI) }\end{array}$ & 26228211 & $\begin{array}{l}\text { Institut Seni } \\
\text { Indonesia } \\
\text { Denpasar }\end{array}$ & $\begin{array}{l}\text { Usulan Baru } \\
\text { mulai Volume } 1 \\
\text { Nomor } 1 \text { Tahun } \\
2018\end{array}$ \\
\hline & 72 & $\begin{array}{l}\text { Journal of } \\
\text { Pharmacopolium }\end{array}$ & 26211521 & $\begin{array}{l}\text { STIKes Bakti } \\
\text { Tunas Husada }\end{array}$ & $\begin{array}{l}\text { Usulan Baru } \\
\text { mulai Volume } 1 \\
\text { Nomor } 1 \text { Tahun } \\
2018\end{array}$ \\
\hline & 73 & $\begin{array}{l}\text { Journal of Science } \\
\text { Education and } \\
\text { Practice }\end{array}$ & 25497170 & $\begin{array}{l}\text { Universitas } \\
\text { Pakuan }\end{array}$ & $\begin{array}{l}\text { Usulan Baru } \\
\text { mulai Volume } 2 \\
\text { Nomor } 1 \text { Tahun } \\
2018\end{array}$ \\
\hline & 74 & J-Proteksion & 25413562 & $\begin{array}{l}\text { Universitas } \\
\text { Muhammadiyah } \\
\text { Jember }\end{array}$ & $\begin{array}{l}\text { Usulan Baru } \\
\text { mulai Volume } 2 \\
\text { Nomor } 2 \text { Tahun } \\
2018\end{array}$ \\
\hline & 75 & $\begin{array}{l}\text { Jurnal Abdiel: } \\
\text { Khazanah } \\
\text { Pemikiran Teologi, } \\
\text { Pendidikan Agama } \\
\text { Kristen, dan Musik } \\
\text { Gereja }\end{array}$ & 26851253 & $\begin{array}{l}\text { Sekolah Tinggi } \\
\text { Theologia Abdiel }\end{array}$ & $\begin{array}{l}\text { Usulan Baru } \\
\text { mulai Volume } 2 \\
\text { Nomor } 1 \text { Tahun } \\
2018\end{array}$ \\
\hline
\end{tabular}




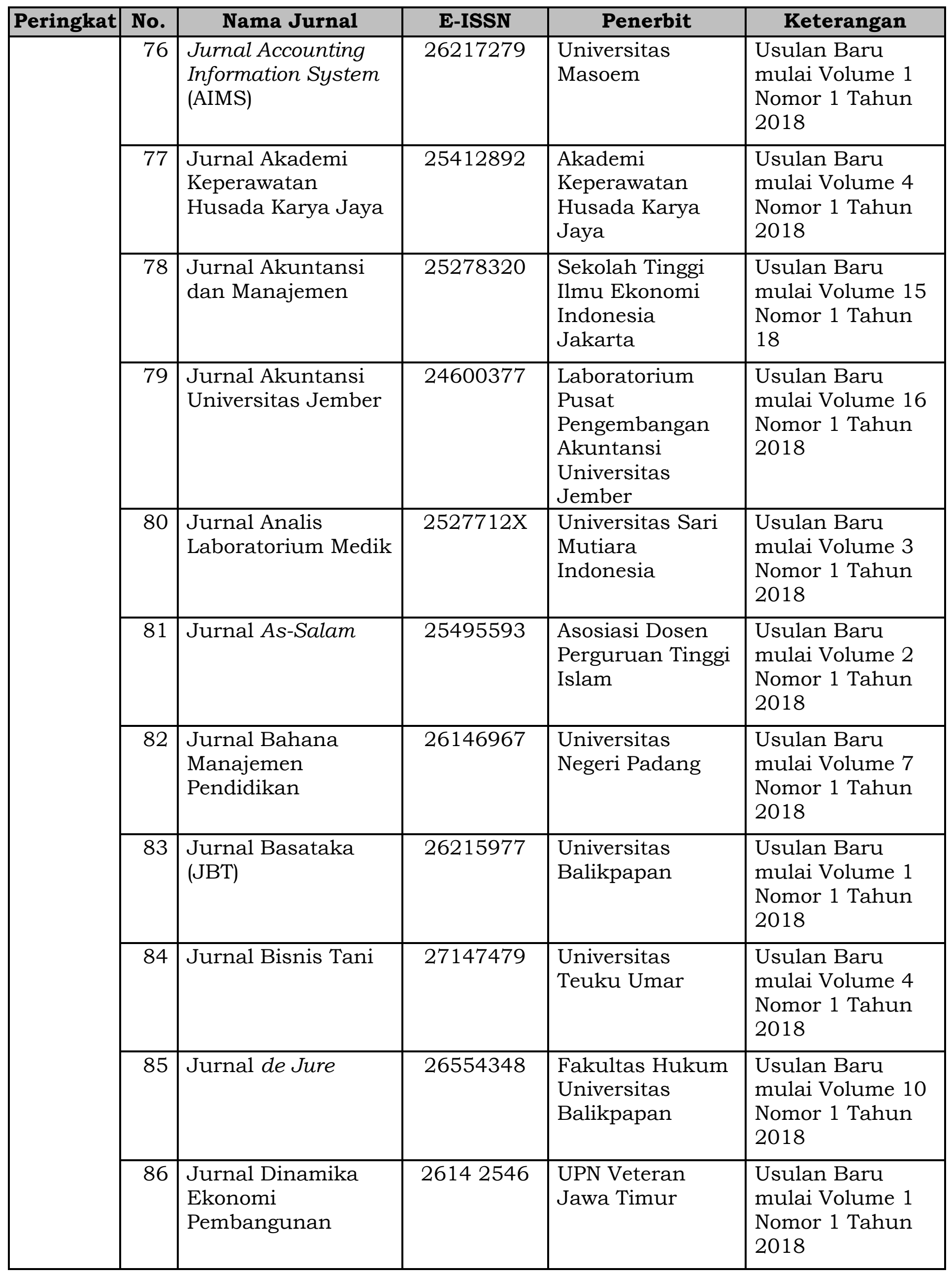




\begin{tabular}{|c|c|c|c|c|c|}
\hline Peringkat & No. & Nama Jurnal & E-ISSN & Penerbit & Keterangan \\
\hline & 87 & Jurnal Doppler & 25803123 & $\begin{array}{l}\text { Prodi Kebidanan } \\
\text { Universitas } \\
\text { Pahlawan } \\
\text { Tuanku } \\
\text { Tambusai } \\
\end{array}$ & $\begin{array}{l}\text { Usulan Baru } \\
\text { mulai Volume } 2 \\
\text { Nomor } 1 \text { Tahun } \\
2018\end{array}$ \\
\hline & 88 & $\begin{array}{l}\text { Jurnal Dunia } \\
\text { Kesmas }\end{array}$ & 25493485 & $\begin{array}{l}\text { Persatuan Dosen } \\
\text { Kesehatan } \\
\text { Masyarakat }\end{array}$ & $\begin{array}{l}\text { Reakreditasi } \\
\text { Tetap di } \\
\text { Peringkat } 5 \text { mulai } \\
\text { Volume } 8 \text { Nomor } \\
4 \text { Tahun } 2019\end{array}$ \\
\hline & 89 & $\begin{array}{l}\text { Jurnal Educatio } \\
\text { FKIP UNMA }\end{array}$ & 25486756 & $\begin{array}{l}\text { Universitas } \\
\text { Majalengka }\end{array}$ & $\begin{array}{l}\text { Usulan Baru } \\
\text { mulai Volume } 4 \\
\text { Nomor } 1 \text { Tahun } \\
2018\end{array}$ \\
\hline & 90 & Jurnal Edueco & 26217511 & $\begin{array}{l}\text { Universitas } \\
\text { Balikpapan }\end{array}$ & $\begin{array}{l}\text { Usulan Baru } \\
\text { mulai Volume } 1 \\
\text { Nomor } 1 \text { Tahun } \\
2018\end{array}$ \\
\hline & 91 & $\begin{array}{l}\text { Jurnal Forum } \\
\text { Mekanika }\end{array}$ & 26558211 & $\begin{array}{l}\text { Sekolah Tinggi } \\
\text { Teknik PLN }\end{array}$ & $\begin{array}{l}\text { Usulan Baru } \\
\text { mulai Volume } 7 \\
\text { Nomor } 1 \text { Tahun } \\
2018\end{array}$ \\
\hline & 92 & Jurnal GeoEkonomi & 25034790 & $\begin{array}{l}\text { Universitas } \\
\text { Balikpapan }\end{array}$ & $\begin{array}{l}\text { Usulan Baru } \\
\text { mulai Volume } 9 \\
\text { Nomor } 1 \text { Tahun } \\
2018\end{array}$ \\
\hline & 93 & $\begin{array}{l}\text { Jurnal Gizi dan } \\
\text { Kesehatan }\end{array}$ & 25803751 & $\begin{array}{l}\text { Program Studi } \\
\text { Gizi Fakultas } \\
\text { Ilmu Kesehatan } \\
\text { Universitas Ngudi } \\
\text { Waluyo }\end{array}$ & $\begin{array}{l}\text { Usulan Baru } \\
\text { mulai Volume } 10 \\
\text { Nomor } 24 \text { Tahun } \\
2018\end{array}$ \\
\hline & 94 & $\begin{array}{l}\text { Jurnal Harpodon } \\
\text { Borneo }\end{array}$ & 25416294 & $\begin{array}{l}\text { Fakultas } \\
\text { Perikanan } \\
\text { Universitas } \\
\text { Borneo Tarakan }\end{array}$ & $\begin{array}{l}\text { Usulan Baru } \\
\text { mulai Volume } 10 \\
\text { Nomor } 2 \text { Tahun } \\
2017\end{array}$ \\
\hline & 95 & $\begin{array}{l}\text { Jurnal IKA PGSD: } \\
\text { Ikatan Alumni } \\
\text { PGSD UNARS }\end{array}$ & 26564459 & $\begin{array}{l}\text { Fakultas } \\
\text { Keguruan dan } \\
\text { Ilmu Pendidikan } \\
\text { Universitas } \\
\text { Abdurachman } \\
\text { Saleh Situbondo }\end{array}$ & $\begin{array}{l}\text { Usulan Baru } \\
\text { mulai Volume } 6 \\
\text { Nomor } 1 \text { Tahun } \\
2018\end{array}$ \\
\hline & 96 & $\begin{array}{l}\text { Jurnal Ilmiah } \\
\text { Betrik: Besemah } \\
\text { Teknologi Informasi } \\
\text { dan Komputer }\end{array}$ & 27157369 & $\begin{array}{l}\text { Sekolah Tinggi } \\
\text { Teknologi Pagar } \\
\text { Alam }\end{array}$ & $\begin{array}{l}\text { Usulan Baru } \\
\text { mulai Volume } 9 \\
\text { Nomor } 1 \text { Tahun } \\
2018\end{array}$ \\
\hline & 97 & $\begin{array}{l}\text { Jurnal Ilmiah } \\
\text { Informatika } \\
\text { Komputer }\end{array}$ & 20898045 & $\begin{array}{l}\text { Universitas } \\
\text { Gunadarma }\end{array}$ & $\begin{array}{l}\text { Usulan Baru } \\
\text { mulai Volume } 23 \\
\text { Nomor } 1 \text { Tahun } \\
2018\end{array}$ \\
\hline
\end{tabular}




\begin{tabular}{|c|c|c|c|c|c|}
\hline \begin{tabular}{|l|} 
Peringkat \\
\end{tabular} & No. & Nama Jurnal & E-ISSN & Penerbit & Keterangan \\
\hline & 98 & $\begin{array}{l}\text { Jurnal Ilmiah } \\
\text { Keperawatan Imelda }\end{array}$ & 25977172 & $\begin{array}{l}\text { Universitas } \\
\text { Imelda Medan }\end{array}$ & $\begin{array}{l}\text { Usulan Baru } \\
\text { mulai Volume } 4 \\
\text { Nomor } 1 \text { Tahun } \\
2018\end{array}$ \\
\hline & 99 & $\begin{array}{l}\text { Jurnal Ilmiah } \\
\text { Pangabdhi }\end{array}$ & 24776289 & $\begin{array}{l}\text { Universitas } \\
\text { Trunojoyo } \\
\text { Madura }\end{array}$ & $\begin{array}{l}\text { Usulan Baru } \\
\text { mulai Volume } 4 \\
\text { Nomor } 1 \text { Tahun } \\
2018\end{array}$ \\
\hline & 100 & $\begin{array}{l}\text { Jurnal Ilmiah } \\
\text { Penegakan Hukum }\end{array}$ & $2622061 X$ & $\begin{array}{l}\text { Universitas } \\
\text { Medan Area }\end{array}$ & $\begin{array}{l}\text { Reakreditasi } \\
\text { Tetap di } \\
\text { Peringkat } 5 \text { mulai } \\
\text { Volume } 6 \text { Nomor } \\
2 \text { Tahun } 2019\end{array}$ \\
\hline & 101 & $\begin{array}{l}\text { Jurnal Ilmiah } \\
\text { Teknik Mesin Al- } \\
\text { Jazari }\end{array}$ & 26150867 & $\begin{array}{l}\text { UPT Publikasi } \\
\text { dan Pengelolaan } \\
\text { Jurnal, } \\
\text { Universitas Islam } \\
\text { Kalimantan }\end{array}$ & $\begin{array}{l}\text { Usulan Baru } \\
\text { mulai Volume } 3 \\
\text { Nomor } 1 \text { Tahun } \\
2018\end{array}$ \\
\hline & 102 & $\begin{array}{l}\text { Jurnal Ilmu } \\
\text { Farmasi dan } \\
\text { Farmasi Klinik } \\
\text { (Journal of } \\
\text { Pharmaceutical } \\
\text { Science and Clinical } \\
\text { Pharmacy) }\end{array}$ & 27163814 & $\begin{array}{l}\text { Universitas } \\
\text { Wahid Hasyim } \\
\text { Semarang }\end{array}$ & $\begin{array}{l}\text { Usulan Baru } \\
\text { mulai Volume } 15 \\
\text { Nomor } 1 \text { Tahun } \\
2018\end{array}$ \\
\hline & 103 & $\begin{array}{l}\text { Jurnal Ilmu } \\
\text { Kesehatan Bhakti } \\
\text { Husada: Health } \\
\text { Science Journal }\end{array}$ & 26231204 & $\begin{array}{l}\text { Lembaga } \\
\text { Penelitian } \\
\text { Sekolah Tinggi } \\
\text { Ilmu Kesehatan } \\
\text { Kuningan } \\
\text { Garawangi } \\
\end{array}$ & $\begin{array}{l}\text { Usulan Baru } \\
\text { mulai Volume } 9 \\
\text { Nomor } 1 \text { Tahun } \\
2018\end{array}$ \\
\hline & 104 & $\begin{array}{l}\text { Jurnal Ilmu } \\
\text { Kesehatan Makia }\end{array}$ & 25499327 & $\begin{array}{l}\text { Lembaga } \\
\text { Penelitian dan } \\
\text { Pengabdian } \\
\text { Masyarakat } \\
\text { (LPPM) STIKes } \\
\text { Insan Cendekia } \\
\text { Husada } \\
\text { Bojonegoro }\end{array}$ & $\begin{array}{l}\text { Usulan Baru } \\
\text { mulai Volume } 6 \\
\text { Nomor } 1 \text { Tahun } \\
2018\end{array}$ \\
\hline & 105 & $\begin{array}{l}\text { Jurnal Imedtech } \\
\text { (Instructional Media, } \\
\text { Design and } \\
\text { Technology) }\end{array}$ & 25806033 & $\begin{array}{l}\text { P2M STKIP Citra } \\
\text { Bakti }\end{array}$ & $\begin{array}{l}\text { Usulan Baru } \\
\text { mulai Volume } 2 \\
\text { Nomor } 1 \text { Tahun } \\
2018\end{array}$ \\
\hline & 106 & $\begin{array}{l}\text { Jurnal Insan } \\
\text { Farmasi Indonesia }\end{array}$ & 26214032 & $\begin{array}{l}\text { Akademi Farmasi } \\
\text { ISFI Banjarmasin }\end{array}$ & $\begin{array}{l}\text { Usulan Baru } \\
\text { mulai Volume } 1 \\
\text { Nomor } 1 \text { Tahun } \\
2018\end{array}$ \\
\hline
\end{tabular}




\begin{tabular}{|c|c|c|c|c|c|}
\hline Peringkat & No. & Nama Jurnal & E-ISSN & Penerbit & Keterangan \\
\hline & 107 & Jurnal Investasi & 24424331 & $\begin{array}{l}\text { Universitas } \\
\text { Wiralodra }\end{array}$ & $\begin{array}{l}\text { Usulan Baru } \\
\text { mulai Volume } 4 \\
\text { Nomor } 1 \text { Tahun } \\
2018\end{array}$ \\
\hline & 108 & $\begin{array}{l}\text { Jurnal Kebidanan } \\
\text { Harapan Ibu } \\
\text { Pekalongan }\end{array}$ & 25795481 & $\begin{array}{l}\text { Akademi } \\
\text { Kebidanan } \\
\text { Harapan Ibu } \\
\text { Pekalongan }\end{array}$ & $\begin{array}{l}\text { Usulan Baru } \\
\text { mulai Volume } 3 \\
\text { Nomor } 1 \text { Tahun } \\
2018\end{array}$ \\
\hline & 109 & $\begin{array}{l}\text { Jurnal Keperawatan } \\
\text { Priority }\end{array}$ & 26144719 & $\begin{array}{l}\text { Universitas Prima } \\
\text { Indonesia }\end{array}$ & $\begin{array}{l}\text { Usulan Baru } \\
\text { mulai Volume } 1 \\
\text { Nomor } 1 \text { Tahun } \\
2018\end{array}$ \\
\hline & 110 & $\begin{array}{l}\text { Jurnal Kesehatan } \\
\text { Delima Pelamonia }\end{array}$ & 26848821 & $\begin{array}{l}\text { Akademi } \\
\text { Kebidanan } \\
\text { Pelamonia } \\
\text { Makassar }\end{array}$ & $\begin{array}{l}\text { Usulan Baru } \\
\text { mulai Volume } 2 \\
\text { Nomor } 1 \text { Tahun } \\
2018\end{array}$ \\
\hline & 111 & $\begin{array}{l}\text { Jurnal Kesehatan } \\
\text { Madani Medika }\end{array}$ & 26847345 & $\begin{array}{l}\text { Sekolah Tinggi } \\
\text { Ilmu Kesehatan } \\
\text { Madani }\end{array}$ & $\begin{array}{l}\text { Usulan Baru } \\
\text { mulai Volume } 9 \\
\text { Nomor } 1 \text { Tahun } \\
2018\end{array}$ \\
\hline & 112 & $\begin{array}{l}\text { Jurnal Kesehatan } \\
\text { Panrita Husada }\end{array}$ & 27151832 & $\begin{array}{l}\text { Stikes Panrita } \\
\text { Husada } \\
\text { Bulukumba }\end{array}$ & $\begin{array}{l}\text { Usulan Baru } \\
\text { mulai Volume } 3 \\
\text { Nomor } 1 \text { Tahun } \\
2018\end{array}$ \\
\hline & 113 & $\begin{array}{l}\text { Jurnal Maternitas } \\
\text { Kebidanan }\end{array}$ & 25991841 & $\begin{array}{l}\text { Universitas Prima } \\
\text { Indonesia }\end{array}$ & $\begin{array}{l}\text { Usulan Baru } \\
\text { mulai Volume } 3 \\
\text { Nomor } 1 \text { Tahun } \\
2018\end{array}$ \\
\hline & 114 & Jurnal Mediagro & 1562648712 & $\begin{array}{l}\text { Fakultas } \\
\text { Pertanian } \\
\text { Universitas } \\
\text { Wahid Hasyim }\end{array}$ & $\begin{array}{l}\text { Usulan Baru } \\
\text { mulai Volume } 13 \\
\text { Nomor } 2 \text { Tahun } \\
2017\end{array}$ \\
\hline & 115 & $\begin{array}{l}\text { Jurnal Medika } \\
\text { Cendikia }\end{array}$ & 24424412 & $\begin{array}{l}\text { STIKes Karsa } \\
\text { Husada Garut }\end{array}$ & $\begin{array}{l}\text { Usulan Baru } \\
\text { mulai Volume } 5 \\
\text { Nomor } 1 \text { Tahun } \\
2018\end{array}$ \\
\hline & 116 & Jurnal Mekanova & 25020498 & $\begin{array}{l}\text { Jurusan Teknik } \\
\text { Mesin Fakultas } \\
\text { Teknik } \\
\text { Universitas } \\
\text { Teuku Umar }\end{array}$ & $\begin{array}{l}\text { Usulan Baru } \\
\text { mulai Volume } 4 \\
\text { Nomor } 1 \text { Tahun } \\
2018\end{array}$ \\
\hline
\end{tabular}

117. Jurnal ... 


\begin{tabular}{|c|c|c|c|c|c|}
\hline Peringkat & No. & Nama Jurnal & E-ISSN & Penerbit & Keterangan \\
\hline & 117 & $\begin{array}{l}\text { Jurnal Middle East } \\
\text { and Islamic Studies } \\
\text { (MEIS) }\end{array}$ & $2685239 X$ & $\begin{array}{l}\text { Program Studi } \\
\text { Kajian Wilayah } \\
\text { Timur Tengah } \\
\text { dan Islam, } \\
\text { Sekolah Kajian } \\
\text { Stratejik dan } \\
\text { Global, } \\
\text { Universitas } \\
\text { Indonesia } \\
\end{array}$ & $\begin{array}{l}\text { Usulan Baru } \\
\text { mulai Volume } 5 \\
\text { Nomor } 1 \text { Tahun } \\
2018\end{array}$ \\
\hline & 118 & $\begin{array}{l}\text { Jurnal Mutiara } \\
\text { Akuntansi }\end{array}$ & 25797611 & $\begin{array}{l}\text { Program Studi } \\
\text { Ilmu Akuntansi } \\
\text { FEIS Universitas } \\
\text { Sari Mutiara } \\
\text { Indonesia } \\
\end{array}$ & $\begin{array}{l}\text { Usulan Baru } \\
\text { mulai Volume } 3 \\
\text { Nomor } 1 \text { Tahun } \\
2018\end{array}$ \\
\hline & 119 & Jurnal Optimalisasi & 25020501 & $\begin{array}{l}\text { Jurusan Teknik } \\
\text { Industri } \\
\text { Universitas } \\
\text { Teuku Umar }\end{array}$ & $\begin{array}{l}\text { Usulan Baru } \\
\text { mulai Volume } 4 \\
\text { Nomor } 1 \text { Tahun } \\
2018\end{array}$ \\
\hline & 120 & $\begin{array}{l}\text { Jurnal Pendidikan } \\
\text { dan Pembelajaran } \\
\text { Sains Indonesia } \\
\text { (JPPSI) }\end{array}$ & 26230852 & $\begin{array}{l}\text { Jurusan Fisika } \\
\text { dan Pengajaran } \\
\text { IPA Universitas } \\
\text { Pendidikan } \\
\text { Ganesha }\end{array}$ & $\begin{array}{l}\text { Usulan Baru } \\
\text { mulai Volume } 1 \\
\text { Nomor } 1 \text { Tahun } \\
2018\end{array}$ \\
\hline & 121 & $\begin{array}{l}\text { Jurnal Pendidikan } \\
\text { Luar Sekolah }\end{array}$ & 27153363 & $\begin{array}{l}\text { Universitas Ibn } \\
\text { Khaldun }\end{array}$ & $\begin{array}{l}\text { Usulan Baru } \\
\text { mulai Volume } 12 \\
\text { Nomor } 1 \text { Tahun } \\
2018\end{array}$ \\
\hline & 122 & $\begin{array}{l}\text { Jurnal Penelitian } \\
\text { Kebijakan } \\
\text { Pendidikan }\end{array}$ & $2654427 \mathrm{X}$ & $\begin{array}{l}\text { Kementerian } \\
\text { Pendidikan dan } \\
\text { Kebudayaan }\end{array}$ & $\begin{array}{l}\text { Usulan Baru } \\
\text { mulai Volume } 11 \\
\text { Nomor } 3 \text { Tahun } \\
2018\end{array}$ \\
\hline & 123 & $\begin{array}{l}\text { Jurnal Pengabdian } \\
\text { Masyarakat Ilmu } \\
\text { Keguruan dan } \\
\text { Pendidikan (JPM- } \\
\text { IKP) }\end{array}$ & 26147491 & $\begin{array}{l}\text { Fakultas } \\
\text { Keguruan dan } \\
\text { Ilmu Pendidikan } \\
\text { Universitas } \\
\text { Trilogi } \\
\end{array}$ & $\begin{array}{l}\text { Usulan Baru } \\
\text { mulai Volume } 1 \\
\text { Nomor } 1 \text { Tahun } \\
2018\end{array}$ \\
\hline & 124 & $\begin{array}{l}\text { Jurnal Pengabdian } \\
\text { Masyarakat MIPA } \\
\text { dan Pendidikan } \\
\text { MIPA }\end{array}$ & 25494899 & $\begin{array}{l}\text { Fakultas } \\
\text { Matematika dan } \\
\text { Ilmu } \\
\text { Pengetahuan } \\
\text { Alam Universitas } \\
\text { Negeri } \\
\text { Yogyakarta } \\
\end{array}$ & $\begin{array}{l}\text { Usulan Baru } \\
\text { mulai Volume } 2 \\
\text { Nomor } 1 \text { Tahun } \\
2018\end{array}$ \\
\hline & 125 & $\begin{array}{l}\text { Jurnal } \\
\text { Pengembangan } \\
\text { Wiraswasta }\end{array}$ & $2620388 \mathrm{X}$ & $\begin{array}{l}\text { LP2M Sekolah } \\
\text { Tinggi Ilmu } \\
\text { Ekonomi IPWI } \\
\text { Jakarta }\end{array}$ & $\begin{array}{l}\text { Usulan Baru } \\
\text { mulai Volume } 20 \\
\text { Nomor } 1 \text { Tahun } \\
2018\end{array}$ \\
\hline
\end{tabular}




\begin{tabular}{|c|c|c|c|c|c|}
\hline Peringkat & No. & Nama Jurnal & E-ISSN & Penerbit & Keterangan \\
\hline & 126 & Jurnal Raudhah & 27162435 & $\begin{array}{l}\text { Universitas Islam } \\
\text { Negeri Sumatera } \\
\text { Utara }\end{array}$ & $\begin{array}{l}\text { Usulan Baru } \\
\text { mulai Volume } 6 \\
\text { Nomor } 2 \text { Tahun } \\
2018\end{array}$ \\
\hline & 127 & $\begin{array}{l}\text { Jurnal Rekayasa } \\
\text { Konstruksi } \\
\text { Mekanika Sipil }\end{array}$ & 27151581 & $\begin{array}{l}\text { Universitas } \\
\text { Katolik Santo } \\
\text { Thomas }\end{array}$ & $\begin{array}{l}\text { Usulan Baru } \\
\text { mulai Volume } 1 \\
\text { Nomor } 1 \text { Tahun } \\
2018\end{array}$ \\
\hline & 128 & $\begin{array}{l}\text { Jurnal Riset } \\
\text { Akuntansi dan } \\
\text { Keuangan }\end{array}$ & 27158136 & $\begin{array}{l}\text { Universitas } \\
\text { Katolik Santo } \\
\text { Thomas }\end{array}$ & $\begin{array}{l}\text { Usulan Baru } \\
\text { mulai Volume } 4 \\
\text { Nomor } 1 \text { Tahun } \\
2018\end{array}$ \\
\hline & 129 & $\begin{array}{l}\text { Jurnal Riset Bisnis } \\
\text { dan Investasi }\end{array}$ & $2684706 \mathrm{X}$ & $\begin{array}{l}\text { Jurusan } \\
\text { Administrasi } \\
\text { Niaga, Politeknik } \\
\text { Negeri Bandung }\end{array}$ & $\begin{array}{l}\text { Usulan Baru } \\
\text { mulai Volume } 4 \\
\text { Nomor } 1 \text { Tahun } \\
2018\end{array}$ \\
\hline & 130 & $\begin{array}{l}\text { Jurnal Seni } \\
\text { Nasional Cikini }\end{array}$ & 27157482 & $\begin{array}{l}\text { Institut Kesenian } \\
\text { Jakarta }\end{array}$ & $\begin{array}{l}\text { Usulan Baru } \\
\text { mulai Volume } 3 \\
\text { Nomor } 3 \text { Tahun } \\
2018\end{array}$ \\
\hline & 131 & $\begin{array}{l}\text { Jurnal Sistem } \\
\text { Informasi } \\
\text { Universitas } \\
\text { Suryadarma }\end{array}$ & 25413228 & $\begin{array}{l}\text { Universitas } \\
\text { Dirgantara } \\
\text { Marsekal } \\
\text { Suryadarma }\end{array}$ & $\begin{array}{l}\text { Usulan Baru } \\
\text { mulai Volume } 5 \\
\text { Nomor } 2 \text { Tahun } \\
2018\end{array}$ \\
\hline & 132 & $\begin{array}{l}\text { Jurnal Speed (Sport, } \\
\text { Physical Education, } \\
\text { Empowerment) }\end{array}$ & 26216698 & $\begin{array}{l}\text { Universitas } \\
\text { Singaperbangsa } \\
\text { Karawang }\end{array}$ & $\begin{array}{l}\text { Usulan Baru } \\
\text { mulai Volume } 1 \\
\text { Nomor } 1 \text { Tahun } \\
2018\end{array}$ \\
\hline & 133 & $\begin{array}{l}\text { Jurnal STEI } \\
\text { Ekonomi }\end{array}$ & 25274783 & $\begin{array}{l}\text { Sekolah Tinggi } \\
\text { Ilmu Ekonomi } \\
\text { Indonesia } \\
\text { Jakarta }\end{array}$ & $\begin{array}{l}\text { Usulan Baru } \\
\text { mulai Volume } 27 \\
\text { Nomor } 1 \text { Tahun } \\
2018\end{array}$ \\
\hline & 134 & $\begin{array}{l}\text { Jurnal Studi } \\
\text { Manajemen dan } \\
\text { Bisnis }\end{array}$ & 24603775 & $\begin{array}{l}\text { Universitas } \\
\text { Trunojoyo } \\
\text { Madura }\end{array}$ & $\begin{array}{l}\text { Usulan Baru } \\
\text { mulai Volume } 5 \\
\text { Nomor } 1 \text { Tahun } \\
2018\end{array}$ \\
\hline & 135 & Jurnal Tahuri & 26854198 & $\begin{array}{l}\text { Universitas } \\
\text { Pattimura }\end{array}$ & $\begin{array}{l}\text { Usulan Baru } \\
\text { mulai Volume } 15 \\
\text { Nomor } 1 \text { Tahun } \\
2018\end{array}$ \\
\hline & 136 & Jurnal Talenta Sipil & 26151634 & $\begin{array}{l}\text { Program Studi } \\
\text { Teknik Sipil } \\
\text { Fakultas Teknik } \\
\text { Universitas } \\
\text { Batanghari }\end{array}$ & $\begin{array}{l}\text { Usulan Baru } \\
\text { mulai Volume } 1 \\
\text { Nomor } 1 \text { Tahun } \\
2018\end{array}$ \\
\hline
\end{tabular}




\begin{tabular}{|c|c|c|c|c|c|}
\hline Peringkat & No. & Nama Jurnal & E-ISSN & Penerbit & Keterangan \\
\hline & 137 & $\begin{array}{l}\text { Jurnal Teknik } \\
\text { Elektro Uniba (JTE } \\
\text { Uniba) }\end{array}$ & 25490842 & $\begin{array}{l}\text { Universitas } \\
\text { Balikpapan }\end{array}$ & $\begin{array}{l}\text { Usulan Baru } \\
\text { mulai Volume } 3 \\
\text { Nomor } 1 \text { Tahun } \\
2018\end{array}$ \\
\hline & 138 & $\begin{array}{l}\text { Jurnal Terapan } \\
\text { Abdimas }\end{array}$ & 25022784 & $\begin{array}{l}\text { Universitas PGRI } \\
\text { Madiun }\end{array}$ & $\begin{array}{l}\text { Reakreditasi } \\
\text { Tetap di } \\
\text { Peringkat } 5 \text { mulai } \\
\text { Volume } 5 \text { Nomor } \\
1 \text { Tahun } 2020 \\
\end{array}$ \\
\hline & 139 & Jurnal Teras Fisika & 26151219 & $\begin{array}{l}\text { Jurusan Fisika } \\
\text { Universitas } \\
\text { Jenderal } \\
\text { Soedirman }\end{array}$ & $\begin{array}{l}\text { Usulan Baru } \\
\text { mulai Volume } 1 \\
\text { Nomor } 1 \text { Tahun } \\
2018\end{array}$ \\
\hline & 140 & $\begin{array}{l}\text { Jutis (Jurnal Teknik } \\
\text { Informatika) }\end{array}$ & 26560860 & $\begin{array}{l}\text { Universitas Islam } \\
\text { Syekh Yusuf } \\
\text { Tangerang }\end{array}$ & $\begin{array}{l}\text { Usulan Baru } \\
\text { mulai Volume } 6 \\
\text { Nomor } 1 \text { Tahun } \\
2018\end{array}$ \\
\hline & 141 & $\begin{array}{l}\text { Kenosis: Jurnal } \\
\text { Kajian Teologi }\end{array}$ & 26564483 & $\begin{array}{l}\text { Institut Agama } \\
\text { Kristen Negeri } \\
\text { Ambon }\end{array}$ & $\begin{array}{l}\text { Usulan Baru } \\
\text { mulai Volume } 4 \\
\text { Nomor } 1 \text { Tahun } \\
2018\end{array}$ \\
\hline & 142 & $\begin{array}{l}\text { Kompak: Jurnal } \\
\text { Ilmiah } \\
\text { Komputerisasi } \\
\text { Akuntansi }\end{array}$ & 26216248 & $\begin{array}{l}\text { Pusat Penelitian } \\
\text { Sekolah Tinggi } \\
\text { Elektronika dan } \\
\text { Komputer } \\
\text { Semarang }\end{array}$ & $\begin{array}{l}\text { Usulan Baru } \\
\text { mulai Volume } 11 \\
\text { Nomor } 1 \text { Tahun } \\
2018\end{array}$ \\
\hline & 143 & $\begin{array}{l}\text { Legalitas: Jurnal } \\
\text { Hukum }\end{array}$ & 25978861 & $\begin{array}{l}\text { Pusat Penelitian } \\
\text { dan } \\
\text { Pengembangan } \\
\text { Hukum, Program } \\
\text { Magister Ilmu } \\
\text { Hukum, } \\
\text { Universitas } \\
\text { Batanghari } \\
\end{array}$ & $\begin{array}{l}\text { Usulan Baru } \\
\text { mulai Volume } 10 \\
\text { Nomor } 1 \text { Tahun } \\
2018\end{array}$ \\
\hline & 144 & $\begin{array}{l}\text { Lekesan: } \\
\text { Interdisciplinary } \\
\text { Journal of Asia } \\
\text { Pacific Arts }\end{array}$ & 25982192 & $\begin{array}{l}\text { Pusat Penerbitan } \\
\text { LP2MPP Institut } \\
\text { Seni Indonesia } \\
\text { Denpasar }\end{array}$ & $\begin{array}{l}\text { Usulan Baru } \\
\text { mulai Volume } 1 \\
\text { Nomor } 1 \text { Tahun } \\
2018\end{array}$ \\
\hline & 145 & $\begin{array}{l}\text { Madani Legal } \\
\text { Review }\end{array}$ & 25806319 & $\begin{array}{l}\text { Universitas } \\
\text { Muhammadiyah } \\
\text { Parepare }\end{array}$ & $\begin{array}{l}\text { Usulan Baru } \\
\text { mulai Volume } 2 \\
\text { Nomor } 1 \text { Tahun } \\
2018\end{array}$ \\
\hline
\end{tabular}

146. Mandala ... 


\begin{tabular}{|c|c|c|c|c|c|}
\hline \multirow[t]{11}{*}{ Peringkat } & No. & Nama Jurnal & E-ISSN & Penerbit & Keterangan \\
\hline & 146 & $\begin{array}{l}\text { Mandala: Jurnal } \\
\text { Ilmu Hubungan } \\
\text { Internasional }\end{array}$ & 25990675 & $\begin{array}{l}\text { Prodi Hubungan } \\
\text { Internasional, } \\
\text { Fakultas Ilmu } \\
\text { Sosial dan Ilmu } \\
\text { Politik, } \\
\text { Universitas } \\
\text { Pembangunan } \\
\text { Nasional Veteran } \\
\text { Jakarta }\end{array}$ & $\begin{array}{l}\text { Usulan Baru } \\
\text { mulai Volume } 1 \\
\text { Nomor } 1 \text { Tahun } \\
2018\end{array}$ \\
\hline & 147 & $\begin{array}{l}\text { Media Penelitian } \\
\text { Pendidikan: Jurnal } \\
\text { Penelitian dalam } \\
\text { Bidang Pendidikan } \\
\text { dan Pengajaran }\end{array}$ & 25280562 & $\begin{array}{l}\text { LPPM Universitas } \\
\text { PGRI Semarang }\end{array}$ & $\begin{array}{l}\text { Reakreditasi } \\
\text { Tetap di } \\
\text { Peringkat } 5 \text { mulai } \\
\text { Volume } 13 \\
\text { Nomor } 2 \text { Tahun } \\
2019\end{array}$ \\
\hline & 148 & $\begin{array}{l}\text { MetaKom: Jurnal } \\
\text { Kajian Komunikasi }\end{array}$ & 27150089 & $\begin{array}{l}\text { Universitas } \\
\text { Lampung }\end{array}$ & $\begin{array}{l}\text { Usulan Baru } \\
\text { mulai Volume } 2 \\
\text { Nomor } 1 \text { Tahun } \\
2018\end{array}$ \\
\hline & 149 & $\begin{array}{l}\text { Mizan: Jurnal Ilmu } \\
\text { Hukum }\end{array}$ & 26572494 & $\begin{array}{l}\text { Universitas Islam } \\
\text { Kadiri }\end{array}$ & $\begin{array}{l}\text { Usulan Baru } \\
\text { mulai Volume } 7 \\
\text { Nomor } 1 \text { Tahun } \\
2018\end{array}$ \\
\hline & 150 & $\begin{array}{l}\text { Mukadimah: Jurnal } \\
\text { Pendidikan, } \\
\text { Sejarah, dan Ilmu- } \\
\text { ilmu Sosial }\end{array}$ & 26221373 & $\begin{array}{l}\text { Program Studi } \\
\text { Pendidikan } \\
\text { Sejarah, FKIP, } \\
\text { Universitas Islam } \\
\text { Sumatera Utara }\end{array}$ & $\begin{array}{l}\text { Usulan Baru } \\
\text { mulai Volume } 2 \\
\text { Nomor } 2 \text { Tahun } \\
2018\end{array}$ \\
\hline & 151 & Nuansa Informatika & 26145405 & $\begin{array}{l}\text { Fakultas Ilmu } \\
\text { Komputer } \\
\text { Universitas } \\
\text { Kuningan }\end{array}$ & $\begin{array}{l}\text { Usulan Baru } \\
\text { mulai Volume } 12 \\
\text { Nomor } 1 \text { Tahun } \\
2018\end{array}$ \\
\hline & 152 & Nursing Arts & $2686133 X$ & $\begin{array}{l}\text { Jurusan } \\
\text { Keperawatan } \\
\text { Poltekkes } \\
\text { Kemenkes } \\
\text { Sorong } \\
\end{array}$ & $\begin{array}{l}\text { Usulan Baru } \\
\text { mulai Volume } 12 \\
\text { Nomor } 1 \text { Tahun } \\
2018\end{array}$ \\
\hline & 153 & $\begin{array}{l}\text { Paedagogia: Jurnal } \\
\text { Pendidikan }\end{array}$ & 25800477 & $\begin{array}{l}\text { Institut Agama } \\
\text { Islam Negeri Palu }\end{array}$ & $\begin{array}{l}\text { Usulan Baru } \\
\text { mulai Volume } 7 \\
\text { Nomor } 1 \text { Tahun } \\
2018\end{array}$ \\
\hline & 154 & $\begin{array}{l}\text { Paradigma } \\
\text { Polistaat: Jurnal } \\
\text { Ilmu Sosial dan } \\
\text { Ilmu Politik }\end{array}$ & 25793888 & $\begin{array}{l}\text { Universitas } \\
\text { Pasundan }\end{array}$ & $\begin{array}{l}\text { Usulan Baru } \\
\text { mulai Volume } 1 \\
\text { Nomor } 1 \text { Tahun } \\
2018\end{array}$ \\
\hline & 155 & $\begin{array}{l}\text { Pena Akuatika: } \\
\text { Jurnal Ilmiah } \\
\text { Perikanan dan } \\
\text { Kelautan }\end{array}$ & $2301640 X$ & $\begin{array}{l}\text { Universitas } \\
\text { Pekalongan }\end{array}$ & $\begin{array}{l}\text { Usulan Baru } \\
\text { mulai Volume } 17 \\
\text { Nomor } 1 \text { Tahun } \\
2018\end{array}$ \\
\hline
\end{tabular}




\begin{tabular}{|c|c|c|c|c|c|}
\hline \begin{tabular}{|l|} 
Peringkat \\
\end{tabular} & No. & Nama Jurnal & E-ISSN & Penerbit & Keterangan \\
\hline & 156 & Petitum & 27160017 & $\begin{array}{l}\text { Universitas } \\
\text { Indonesia Timur }\end{array}$ & $\begin{array}{l}\text { Usulan Baru } \\
\text { mulai Volume } 6 \\
\text { Nomor } 1 \text { Tahun } \\
2018\end{array}$ \\
\hline & 157 & $\begin{array}{l}\text { Pharmauho: Jurnal } \\
\text { Farmasi, Sains, dan } \\
\text { Kesehatan }\end{array}$ & 27154181 & $\begin{array}{l}\text { Universitas Halu } \\
\text { Oleo }\end{array}$ & $\begin{array}{l}\text { Usulan Baru } \\
\text { mulai Volume } 4 \\
\text { Nomor } 1 \text { Tahun } \\
2018\end{array}$ \\
\hline & 158 & $\begin{array}{l}\text { PHI: Jurnal } \\
\text { Pendidikan } \\
\text { Matematika }\end{array}$ & 25980661 & $\begin{array}{l}\text { Program Studi } \\
\text { Pendidikan } \\
\text { Matematika, } \\
\text { Fakultas } \\
\text { Keguruan dan } \\
\text { Ilmu Pendidikan } \\
\text { Universitas } \\
\text { Batanghari }\end{array}$ & $\begin{array}{l}\text { Usulan Baru } \\
\text { mulai Volume } 2 \\
\text { Nomor } 1 \text { Tahun } \\
2018\end{array}$ \\
\hline & 159 & $\begin{array}{l}\text { Piwulang Jawi: } \\
\text { Journal of Javanese } \\
\text { Learning and } \\
\text { Teaching }\end{array}$ & 22526307 & $\begin{array}{l}\text { Jurusan Bahasa } \\
\text { dan Sastra Jawa, } \\
\text { Fakultas Bahasa } \\
\text { dan Seni, } \\
\text { Universitas } \\
\text { Negeri Semarang }\end{array}$ & $\begin{array}{l}\text { Usulan Baru } \\
\text { mulai Volume } 6 \\
\text { Nomor } 1 \text { Tahun } \\
2018\end{array}$ \\
\hline & 160 & $\begin{array}{l}\text { Politea: Jurnal } \\
\text { Politik Islam }\end{array}$ & 27151166 & UIN Mataram & $\begin{array}{l}\text { Usulan Baru } \\
\text { mulai Volume } 1 \\
\text { Nomor } 1 \text { Tahun } \\
2018\end{array}$ \\
\hline & 161 & $\begin{array}{l}\text { PROFIT: Jurnal } \\
\text { Administrasi Bisnis }\end{array}$ & 23384654 & $\begin{array}{l}\text { Fakultas Ilmu } \\
\text { Administrasi } \\
\text { Universitas } \\
\text { Brawijaya }\end{array}$ & $\begin{array}{l}\text { Usulan Baru } \\
\text { mulai Volume } 12 \\
\text { Nomor } 1 \text { Tahun } \\
2018\end{array}$ \\
\hline & 162 & $\begin{array}{l}\text { Progressa: Journal } \\
\text { of Islamic Religious } \\
\text { Instruction }\end{array}$ & 25799673 & $\begin{array}{l}\text { STIT Raden } \\
\text { Wijaya Mojokerto }\end{array}$ & $\begin{array}{l}\text { Usulan Baru } \\
\text { mulai Volume } 2 \\
\text { Nomor } 1 \text { Tahun } \\
2018\end{array}$ \\
\hline & 163 & $\begin{array}{l}\text { Prokons: Jurnal } \\
\text { Teknik Sipil }\end{array}$ & 27148815 & $\begin{array}{l}\text { Politeknik Negeri } \\
\text { Malang, jurusan } \\
\text { teknik sipil }\end{array}$ & $\begin{array}{l}\text { Usulan Baru } \\
\text { mulai Volume } 12 \\
\text { Nomor } 1 \text { Tahun } \\
2018\end{array}$ \\
\hline & 164 & $\begin{array}{l}\text { Promosi: Jurnal } \\
\text { Program Studi } \\
\text { Pendidikan } \\
\text { Ekonomi }\end{array}$ & 24429449 & $\begin{array}{l}\text { Universitas } \\
\text { Muhammadiyah } \\
\text { Metro }\end{array}$ & $\begin{array}{l}\text { Reakreditasi } \\
\text { Tetap di } \\
\text { Peringkat } 5 \text { mulai } \\
\text { Volume } 6 \text { Nomor } \\
1 \text { Tahun } 2018\end{array}$ \\
\hline & 165 & Prosodi & 26220474 & $\begin{array}{l}\text { Universitas } \\
\text { Trunojoyo } \\
\text { Madura }\end{array}$ & $\begin{array}{l}\text { Usulan Baru } \\
\text { mulai Volume } 12 \\
\text { Nomor } 1 \text { Tahun } \\
2018\end{array}$ \\
\hline
\end{tabular}

166. Psikodidaktika ... 


\begin{tabular}{|c|c|c|c|c|c|}
\hline Peringkat & No. & Nama Jurnal & E-ISSN & Penerbit & Keterangan \\
\hline & 166 & $\begin{array}{l}\text { Psikodidaktika: } \\
\text { Jurnal Ilmu } \\
\text { Pendidikan, } \\
\text { Psikologi, } \\
\text { Bimbingan dan } \\
\text { Konseling } \\
\end{array}$ & 26153297 & $\begin{array}{l}\text { Universitas Prof } \\
\text { Dr Hazairin SH }\end{array}$ & $\begin{array}{l}\text { Usulan Baru } \\
\text { mulai Volume } 3 \\
\text { Nomor } 1 \text { Tahun } \\
2018\end{array}$ \\
\hline & 167 & $\begin{array}{l}\text { Publica: Jurnal } \\
\text { Pemikiran } \\
\text { Administrasi Negara }\end{array}$ & 27159256 & $\begin{array}{l}\text { Universitas Islam } \\
\text { Negeri Sunan } \\
\text { Gunung Djati } \\
\text { Bandung }\end{array}$ & $\begin{array}{l}\text { Usulan Baru } \\
\text { mulai Volume } 10 \\
\text { Nomor } 1 \text { Tahun } \\
2018\end{array}$ \\
\hline & 168 & $\begin{array}{l}\text { Rawa Sains: Jurnal } \\
\text { Sains STIPER } \\
\text { Amuntai }\end{array}$ & 26863510 & $\begin{array}{l}\text { Sekolah Tinggi } \\
\text { Ilmu Pertanian } \\
\text { Amuntai }\end{array}$ & $\begin{array}{l}\text { Usulan Baru } \\
\text { mulai Volume } 8 \\
\text { Nomor } 1 \text { Tahun } \\
2018\end{array}$ \\
\hline & 169 & Rayah A1-Islam & 26862018 & STIBA Arraayah & $\begin{array}{l}\text { Usulan Baru } \\
\text { mulai Volume } 2 \\
\text { Nomor } 1 \text { Tahun } \\
2018\end{array}$ \\
\hline & 170 & $\begin{array}{l}\text { Research Journal of } \\
\text { Accounting and } \\
\text { Business } \\
\text { Management }\end{array}$ & 25803131 & $\begin{array}{l}\text { Universitas } 17 \\
\text { Agustus } 1945 \\
\text { Samarinda }\end{array}$ & $\begin{array}{l}\text { Usulan Baru } \\
\text { mulai Volume } 2 \\
\text { Nomor } 1 \text { Tahun } \\
2018\end{array}$ \\
\hline & 171 & $\begin{array}{l}\text { Saintek: Jurnal } \\
\text { ilmiah Sains dan } \\
\text { Teknologi Industri }\end{array}$ & 25978586 & $\begin{array}{l}\text { Universitas } \\
\text { Katolik Musi } \\
\text { Charitas }\end{array}$ & $\begin{array}{l}\text { Usulan Baru } \\
\text { mulai Volume } 2 \\
\text { Nomor } 1 \text { Tahun } \\
2018\end{array}$ \\
\hline & 172 & $\begin{array}{l}\text { Santhet: Jurnal } \\
\text { Sejarah, Pendidikan } \\
\text { dan Humaniora }\end{array}$ & 25416103 & $\begin{array}{l}\text { Universitas PGRI } \\
\text { Banyuwangi }\end{array}$ & $\begin{array}{l}\text { Usulan Baru } \\
\text { mulai Volume } 2 \\
\text { Nomor } 1 \text { Tahun } \\
2018\end{array}$ \\
\hline & 173 & $\begin{array}{l}\text { ScientiCO: Computer } \\
\text { Science and } \\
\text { Informatics Journal }\end{array}$ & 26204118 & $\begin{array}{l}\text { Universitas } \\
\text { Tadulako }\end{array}$ & $\begin{array}{l}\text { Usulan Baru } \\
\text { mulai Volume } 1 \\
\text { Nomor } 1 \text { Tahun } \\
2018\end{array}$ \\
\hline & 174 & $\begin{array}{l}\text { Selaparang: Jurnal } \\
\text { Pengabdian } \\
\text { Masyarakat } \\
\text { Berkemajuan }\end{array}$ & $2614526 \mathrm{X}$ & $\begin{array}{l}\text { Program Studi } \\
\text { Pendidikan } \\
\text { Fisika } \\
\text { Universitas } \\
\text { Muhammadiyah } \\
\text { Mataram } \\
\text { Mataram }\end{array}$ & $\begin{array}{l}\text { Usulan Baru } \\
\text { mulai Volume } 1 \\
\text { Nomor } 2 \text { Tahun } \\
2018\end{array}$ \\
\hline & 175 & $\begin{array}{l}\text { Serat Rupa Journal } \\
\text { of Design }\end{array}$ & $2477586 \mathrm{X}$ & $\begin{array}{l}\text { Universitas } \\
\text { Kristen } \\
\text { Maranatha }\end{array}$ & $\begin{array}{l}\text { Usulan Baru } \\
\text { mulai Volume } 2 \\
\text { Nomor } 2 \text { Tahun } \\
2018\end{array}$ \\
\hline & 176 & $\begin{array}{l}\text { SIMAK: Jurnal } \\
\text { Sistem Informasi, } \\
\text { Manajemen, dan } \\
\text { Akuntansi }\end{array}$ & 26210320 & $\begin{array}{l}\text { Universitas Atma } \\
\text { Jaya Makassar }\end{array}$ & $\begin{array}{l}\text { Usulan Baru } \\
\text { mulai Volume } 16 \\
\text { Nomor } 1 \text { Tahun } \\
2018\end{array}$ \\
\hline
\end{tabular}




\begin{tabular}{|c|c|c|c|c|c|}
\hline Peringkat & No. & Nama Jurnal & E-ISSN & Penerbit & Keterangan \\
\hline & 177 & $\begin{array}{l}\text { Sorai: Jurnal } \\
\text { Pengkajian dan } \\
\text { Penciptaan Musik }\end{array}$ & 26849445 & $\begin{array}{l}\text { Institut Seni } \\
\text { Indonesia } \\
\text { Surakarta }\end{array}$ & $\begin{array}{l}\text { Usulan Baru } \\
\text { mulai Volume } 11 \\
\text { Nomor } 1 \text { Tahun } \\
2018\end{array}$ \\
\hline & 178 & $\begin{array}{l}\text { Specta Journal of } \\
\text { Technology }\end{array}$ & 26229099 & $\begin{array}{l}\text { LPPM Institut } \\
\text { Teknologi } \\
\text { Kalimantan }\end{array}$ & $\begin{array}{l}\text { Usulan Baru } \\
\text { mulai Volume } 1 \\
\text { Nomor } 3 \text { Tahun } \\
2017\end{array}$ \\
\hline & 179 & $\begin{array}{l}\text { Ta Limuna: Jurnal } \\
\text { Pendidikan Islam }\end{array}$ & 20852975 & $\begin{array}{l}\text { STAI Ma'had Aly } \\
\text { Al Hikam Malang }\end{array}$ & $\begin{array}{l}\text { Usulan Baru } \\
\text { mulai Volume } 7 \\
\text { Nomor } 1 \text { Tahun } \\
2018\end{array}$ \\
\hline & 180 & $\begin{array}{l}\text { Tahdis: Jurnal } \\
\text { Kajian Ilmu Al- } \\
\text { Hadis }\end{array}$ & 27162109 & $\begin{array}{l}\text { Universitas Islam } \\
\text { Negeri Alauddin } \\
\text { Makassar }\end{array}$ & $\begin{array}{l}\text { Usulan Baru } \\
\text { mulai Volume } 9 \\
\text { Nomor } 1 \text { Tahun } \\
2018\end{array}$ \\
\hline & 181 & $\begin{array}{l}\text { Techno Xplore: } \\
\text { Jurnal Ilmu } \\
\text { Komputer dan } \\
\text { Teknologi Informasi }\end{array}$ & 25809288 & $\begin{array}{l}\text { Universitas } \\
\text { Buana } \\
\text { Perjuangan } \\
\text { Karawang }\end{array}$ & $\begin{array}{l}\text { Usulan Baru } \\
\text { mulai Volume } 3 \\
\text { Nomor } 1 \text { Tahun } \\
2018\end{array}$ \\
\hline & 182 & $\begin{array}{l}\text { Jurnal Teknik } \\
\text { Teknika }\end{array}$ & 26865416 & $\begin{array}{l}\text { Universitas IBA } \\
\text { Palembang }\end{array}$ & $\begin{array}{l}\text { Usulan Baru } \\
\text { mulai Volume } 13 \\
\text { Nomor } 1 \text { Tahun } \\
2018\end{array}$ \\
\hline & 183 & Teknika & 25808478 & $\begin{array}{l}\text { Program Studi } \\
\text { Teknik Sipil, } \\
\text { Fakultas Teknik, } \\
\text { Universitas } \\
\text { Semarang }\end{array}$ & $\begin{array}{l}\text { Usulan Baru } \\
\text { mulai Volume } 5 \\
\text { Nomor } 1 \text { Tahun } \\
2018\end{array}$ \\
\hline & 184 & $\begin{array}{l}\text { To Maega: Jurnal } \\
\text { Pengabdian } \\
\text { Masyarakat }\end{array}$ & 26226340 & $\begin{array}{l}\text { Universitas Andi } \\
\text { Djemma Palopo }\end{array}$ & $\begin{array}{l}\text { Usulan Baru } \\
\text { mulai Volume } 1 \\
\text { Nomor } 1 \text { Tahun } \\
2018\end{array}$ \\
\hline & 185 & $\begin{array}{l}\text { Transborders: } \\
\text { International } \\
\text { Relations Journal }\end{array}$ & 25989200 & $\begin{array}{l}\text { Jurusan } \\
\text { Hubungan } \\
\text { Internasional } \\
\text { FISIP Universitas } \\
\text { Pasundan } \\
\end{array}$ & $\begin{array}{l}\text { Usulan Baru } \\
\text { mulai Volume } 1 \\
\text { Nomor } 1 \text { Tahun } \\
2017\end{array}$ \\
\hline & 186 & UMI Medical Journal & 26857561 & $\begin{array}{l}\text { Universitas } \\
\text { Muslim } \\
\text { Indonesia }\end{array}$ & $\begin{array}{l}\text { Usulan Baru } \\
\text { mulai Volume } 3 \\
\text { Nomor } 1 \text { Tahun } \\
2018\end{array}$ \\
\hline & 187 & Untag Law Review & 25494910 & $\begin{array}{l}\text { Fakultas Hukum } \\
\text { Universitas } 17 \\
\text { Agustus } 1945 \\
\text { Semarang }\end{array}$ & $\begin{array}{l}\text { Usulan Baru } \\
\text { mulai Volume } 2 \\
\text { Nomor } 1 \text { Tahun } \\
2018\end{array}$ \\
\hline
\end{tabular}




\begin{tabular}{|c|c|c|c|c|c|}
\hline Peringkat & No. & Nama Jurnal & E-ISSN & Penerbit & Keterangan \\
\hline & 188 & $\begin{array}{l}\text { Vidya Wertta: Media } \\
\text { Komunikasi } \\
\text { Universitas Hindu } \\
\text { Indonesia }\end{array}$ & 26557282 & $\begin{array}{l}\text { Universitas } \\
\text { Hindu Indonesia }\end{array}$ & $\begin{array}{l}\text { Usulan Baru } \\
\text { mulai Volume } 1 \\
\text { Nomor } 2 \text { Tahun } \\
2018\end{array}$ \\
\hline & 189 & $\begin{array}{l}\text { Viva Medika: Jurnal } \\
\text { Kesehatan, } \\
\text { Kebidanan dan } \\
\text { Keperawatan }\end{array}$ & 26561034 & $\begin{array}{l}\text { Universitas } \\
\text { Harapan Bangsa } \\
\text { Banyumas }\end{array}$ & $\begin{array}{l}\text { Usulan Baru } \\
\text { mulai Volume } 1 \\
\text { Nomor } 1 \text { Tahun } \\
2018\end{array}$ \\
\hline & 190 & Widya Teknik & 26213362 & $\begin{array}{l}\text { Unika Widya } \\
\text { Mandala } \\
\text { Surabaya }\end{array}$ & $\begin{array}{l}\text { Usulan Baru } \\
\text { mulai Volume } 17 \\
\text { Nomor } 1 \text { Tahun } \\
2018\end{array}$ \\
\hline & 191 & $\begin{array}{l}\text { Widyadari: Jurnal } \\
\text { Pendidikan }\end{array}$ & 26139308 & $\begin{array}{l}\text { LPPM IKIP PGRI } \\
\text { Bali }\end{array}$ & $\begin{array}{l}\text { Usulan Baru } \\
\text { mulai Volume } 19 \\
\text { Nomor } 1 \text { Tahun } \\
2018\end{array}$ \\
\hline \multirow[t]{6}{*}{6} & $\overline{1}$ & $\begin{array}{l}\text { Akbis: Media Riset } \\
\text { Akuntansi dan } \\
\text { Bisnis }\end{array}$ & 26555050 & $\begin{array}{l}\text { Prodi Akuntansi } \\
\text { Fakultas } \\
\text { Ekonomi } \\
\text { Universitas } \\
\text { Teuku Umar }\end{array}$ & $\begin{array}{l}\text { Usulan Baru } \\
\text { mulai Volume } 2 \\
\text { Nomor } 1 \text { Tahun } \\
2018\end{array}$ \\
\hline & 2 & Ekonomi Bisnis & 27151662 & $\begin{array}{l}\text { Fakultas } \\
\text { Ekonomi dan } \\
\text { Bisnis } \\
\text { Universitas Islam } \\
\text { Syekh Yusuf } \\
\text { Tangerang } \\
\end{array}$ & $\begin{array}{l}\text { Usulan Baru } \\
\text { mulai Volume } 24 \\
\text { Nomor } 1 \text { Tahun } \\
2018\end{array}$ \\
\hline & $\overline{3}$ & Inovish Journal & 25283804 & $\begin{array}{l}\text { Politeknik Negeri } \\
\text { Bengkalis }\end{array}$ & $\begin{array}{l}\text { Usulan Baru } \\
\text { mulai Volume } 3 \\
\text { Nomor } 1 \text { Tahun } \\
2018\end{array}$ \\
\hline & 4 & $\begin{array}{l}\text { International } \\
\text { Journal of } \\
\text { Education, } \\
\text { Information } \\
\text { Technology, and } \\
\text { Others } \\
\end{array}$ & 26542528 & $\begin{array}{l}\text { Fakultas Ilmu } \\
\text { Pendidikan } \\
\text { Universitas Bumi } \\
\text { Hijrah }\end{array}$ & $\begin{array}{l}\text { Usulan Baru } \\
\text { mulai Volume } 1 \\
\text { Nomor } 1 \text { Tahun } \\
2018\end{array}$ \\
\hline & 5 & $\begin{array}{l}\text { Ius Civile: Refleksi } \\
\text { Penegakan Hukum } \\
\text { dan Keadilan }\end{array}$ & 26206617 & $\begin{array}{l}\text { Universitas } \\
\text { Teuku Umar }\end{array}$ & $\begin{array}{l}\text { Usulan Baru } \\
\text { mulai Volume } 2 \\
\text { Nomor } 1 \text { Tahun } \\
2018\end{array}$ \\
\hline & $\overline{6}$ & $\begin{array}{l}\text { Journal of English } \\
\text { Language and } \\
\text { Education }\end{array}$ & 25976850 & $\begin{array}{l}\text { Program Studi } \\
\text { Pendidikan } \\
\text { Bahasa Inggris } \\
\text { Universitas } \\
\text { Pahlawan } \\
\text { Tuanku } \\
\text { Tambusai }\end{array}$ & $\begin{array}{l}\text { Usulan Baru } \\
\text { mulai Volume } 3 \\
\text { Nomor } 1 \text { Tahun } \\
2018\end{array}$ \\
\hline
\end{tabular}




\begin{tabular}{|c|c|c|c|c|c|}
\hline Peringkat & No. & Nama Jurnal & E-ISSN & Penerbit & Keterangan \\
\hline & 7 & $\begin{array}{l}\text { Jurma: Jurnal } \\
\text { Program Mahasiswa } \\
\text { Kreatif }\end{array}$ & 26158019 & $\begin{array}{l}\text { LPPM Universitas } \\
\text { Ibn Khaldun } \\
\text { Bogor }\end{array}$ & $\begin{array}{l}\text { Usulan Baru } \\
\text { mulai Volume } 2 \\
\text { Nomor } 1 \text { Tahun } \\
2018\end{array}$ \\
\hline & 8 & $\begin{array}{l}\text { Jurnal Akuakultura } \\
\text { Universitas Teuku } \\
\text { Umar }\end{array}$ & 26207397 & $\begin{array}{l}\text { Universitas } \\
\text { Teuku Umar }\end{array}$ & $\begin{array}{l}\text { Usulan Baru } \\
\text { mulai Volume } 2 \\
\text { Nomor } 1 \text { Tahun } \\
2018\end{array}$ \\
\hline & 9 & $\begin{array}{l}\text { Jurnal Desain Idea: } \\
\text { Jurnal Desain } \\
\text { Produk Industri } \\
\text { Institut Teknologi } \\
\text { Sepuluh Nopember } \\
\text { Surabaya }\end{array}$ & 25800264 & $\begin{array}{l}\text { Pusat Publikasi } \\
\text { Ilmiah LPPM } \\
\text { Institut Teknologi } \\
\text { Sepuluh } \\
\text { November }\end{array}$ & $\begin{array}{l}\text { Usulan Baru } \\
\text { mulai Volume } 17 \\
\text { Nomor } 1 \text { Tahun } \\
2018\end{array}$ \\
\hline & 10 & Jurnal Idea Hukum & 24427241 & $\begin{array}{l}\text { Program Studi } \\
\text { Magister Hukum, } \\
\text { Fakultas Hukum } \\
\text { Universitas } \\
\text { Jenderal } \\
\text { Soedirman }\end{array}$ & $\begin{array}{l}\text { Usulan Baru } \\
\text { mulai Volume } 4 \\
\text { Nomor } 1 \text { Tahun } \\
2018\end{array}$ \\
\hline & 11 & $\begin{array}{l}\text { Jurnal Ilmiah } \\
\text { Aquinas }\end{array}$ & 27146472 & $\begin{array}{l}\text { Universitas } \\
\text { Katolik Santo } \\
\text { Thomas } \\
\text { Sumatera Utara }\end{array}$ & $\begin{array}{l}\text { Usulan Baru } \\
\text { mulai Volume } 1 \\
\text { Nomor } 2 \text { Tahun } \\
2018\end{array}$ \\
\hline & 12 & $\begin{array}{l}\text { Jurnal Ilmiah Ilmu } \\
\text { dan Teknologi } \\
\text { Rekayasa }\end{array}$ & 26150387 & $\begin{array}{l}\text { Pusat Penelitian } \\
\text { dan Pengabdian } \\
\text { Kepada } \\
\text { Masyarakat } \\
\text { Politeknik Negeri } \\
\text { Subang }\end{array}$ & $\begin{array}{l}\text { Usulan Baru } \\
\text { mulai Volume } 1 \\
\text { Nomor } 1 \text { Tahun } \\
2018\end{array}$ \\
\hline & 13 & $\begin{array}{l}\text { Jurnal Ilmiah } \\
\text { Sosiologi Agama } \\
\text { (JISA) }\end{array}$ & 26208059 & $\begin{array}{l}\text { Prodi Sosiologi } \\
\text { Agama Fakultas } \\
\text { Ilmu Sosial UIN } \\
\text { Sumatera Utara }\end{array}$ & $\begin{array}{l}\text { Usulan Baru } \\
\text { mulai Volume } 1 \\
\text { Nomor } 1 \text { Tahun } \\
2018\end{array}$ \\
\hline & 14 & $\begin{array}{l}\text { Jurnal Ilmu } \\
\text { Komputer dan } \\
\text { Bisnis }\end{array}$ & 25989715 & $\begin{array}{l}\text { Sekolah Tinggi } \\
\text { Manajemen } \\
\text { Informatika Dan } \\
\text { Komputer } \\
\text { Dharmapala Riau }\end{array}$ & $\begin{array}{l}\text { Usulan Baru } \\
\text { mulai Volume } 9 \\
\text { Nomor } 1 \text { Tahun } \\
2018\end{array}$ \\
\hline & 15 & $\begin{array}{l}\text { Jurnal Ilmu } \\
\text { Pendidikan } \\
\text { Ahlussunnah }\end{array}$ & 26208458 & $\begin{array}{l}\text { Sekolah Tinggi } \\
\text { Keguruan dan } \\
\text { Ilmu Pendidikan } \\
\text { Ahlussunnah }\end{array}$ & $\begin{array}{l}\text { Usulan Baru } \\
\text { mulai Volume } 1 \\
\text { Nomor } 1 \text { Tahun } \\
2018\end{array}$ \\
\hline & 16 & $\begin{array}{l}\text { Jurnal Kacapuri: } \\
\text { Jurnal Keilmuan } \\
\text { Teknik Sipil }\end{array}$ & 26566001 & $\begin{array}{l}\text { Universitas Islam } \\
\text { Kalimantan } \\
\text { Muhammad } \\
\text { Aryad Al-Banjari }\end{array}$ & $\begin{array}{l}\text { Usulan Baru } \\
\text { mulai Volume } 1 \\
\text { Nomor } 1 \text { Tahun } \\
2018\end{array}$ \\
\hline
\end{tabular}




\begin{tabular}{|c|c|c|c|c|c|}
\hline Peringkat & No. & Nama Jurnal & E-ISSN & Penerbit & Keterangan \\
\hline & 17 & $\begin{array}{l}\text { Jurnal Online } \\
\text { Keperawatan } \\
\text { Indonesia }\end{array}$ & 26212161 & $\begin{array}{l}\text { Universitas Sari } \\
\text { Mutiara } \\
\text { Indonesia }\end{array}$ & $\begin{array}{l}\text { Usulan Baru } \\
\text { mulai Volume } 1 \\
\text { Nomor } 1 \text { Tahun } \\
2018\end{array}$ \\
\hline & 18 & $\begin{array}{l}\text { Jurnal Pamator: } \\
\text { Jurnal Ilmiah } \\
\text { Universitas } \\
\text { Trunojoyo Madura }\end{array}$ & 26547856 & $\begin{array}{l}\text { Universitas } \\
\text { Trunojoyo } \\
\text { Madura }\end{array}$ & $\begin{array}{l}\text { Usulan Baru } \\
\text { mulai Volume } 11 \\
\text { Nomor } 1 \text { Tahun } \\
2018\end{array}$ \\
\hline & 19 & $\begin{array}{l}\text { Jurnal Pendidikan } \\
\text { Matematika Unila }\end{array}$ & $2715856 \mathrm{X}$ & $\begin{array}{l}\text { Universitas } \\
\text { Lampung }\end{array}$ & $\begin{array}{l}\text { Usulan Baru } \\
\text { mulai Volume } 6 \\
\text { Nomor } 1 \text { Tahun } \\
2018\end{array}$ \\
\hline & 20 & $\begin{array}{l}\text { Jurnal Pendidikan } \\
\text { Modern }\end{array}$ & $2580099 X$ & $\begin{array}{l}\text { LPPM STKIP } \\
\text { Modern Ngawi }\end{array}$ & $\begin{array}{l}\text { Usulan Baru } \\
\text { mulai Volume } 3 \\
\text { Nomor } 2 \text { Tahun } \\
2018\end{array}$ \\
\hline & 21 & $\begin{array}{l}\text { Jurnal Riset } \\
\text { Pendidikan } \\
\text { Ekonomi }\end{array}$ & 25409247 & $\begin{array}{l}\text { Fakultas } \\
\text { Ekonomika dan } \\
\text { Bisnis, } \\
\text { Universitas } \\
\text { Kanjuruhan } \\
\text { Malang }\end{array}$ & $\begin{array}{l}\text { Usulan Baru } \\
\text { mulai Volume } 3 \\
\text { Nomor } 1 \text { Tahun } \\
2018\end{array}$ \\
\hline & 22 & $\begin{array}{l}\text { Jurnal Seni } \\
\text { Makalangan }\end{array}$ & 27148920 & $\begin{array}{l}\text { Institut Seni } \\
\text { Budaya } \\
\text { Indonesia } \\
\text { Bandung }\end{array}$ & $\begin{array}{l}\text { Usulan Baru } \\
\text { mulai Volume } 5 \\
\text { Nomor } 1 \text { Tahun } \\
2018\end{array}$ \\
\hline & 23 & $\begin{array}{l}\text { Jurnal Teknologi } \\
\text { Technoscientia }\end{array}$ & 27148025 & $\begin{array}{l}\text { Institut Sains \& } \\
\text { Teknologi } \\
\text { AKPRIND } \\
\text { Yogyakarta }\end{array}$ & $\begin{array}{l}\text { Usulan Baru } \\
\text { mulai Volume } 10 \\
\text { Nomor } 2 \text { Tahun } \\
2018\end{array}$ \\
\hline & 24 & $\begin{array}{l}\text { Maha Widya } \\
\text { Bhuwana: Jurnal } \\
\text { Pendidikan, Agama } \\
\text { dan Budaya }\end{array}$ & 26544903 & $\begin{array}{l}\text { STAHN Mpu } \\
\text { Kuturan } \\
\text { Singaraja }\end{array}$ & $\begin{array}{l}\text { Usulan Baru } \\
\text { mulai Volume } 1 \\
\text { Nomor } 1 \text { Tahun } \\
2018\end{array}$ \\
\hline & 25 & Maleo Law Journal & 25805835 & $\begin{array}{l}\text { Fakultas Hukum } \\
\text { Universitas } \\
\text { Muhammadiyah } \\
\text { Palu }\end{array}$ & $\begin{array}{l}\text { Usulan Baru } \\
\text { mulai Volume } 2 \\
\text { Nomor } 1 \text { Tahun } \\
2018\end{array}$ \\
\hline & 26 & $\begin{array}{l}\text { Media Manajemen } \\
\text { Jasa }\end{array}$ & 25023632 & $\begin{array}{l}\text { Universitas } 17 \\
\text { Agustus } 1945 \\
\text { Jakarta }\end{array}$ & $\begin{array}{l}\text { Usulan Baru } \\
\text { mulai Volume } 6 \\
\text { Nomor } 1 \text { Tahun } \\
2018\end{array}$ \\
\hline & 27 & $\begin{array}{l}\text { Pixel: Jurnal Ilmiah } \\
\text { Komputer Grafis }\end{array}$ & 26216256 & $\begin{array}{l}\text { Sekolah Tinggi } \\
\text { Elektronika dan } \\
\text { Komputer }\end{array}$ & $\begin{array}{l}\text { Usulan Baru } \\
\text { mulai Volume } 11 \\
\text { Nomor } 1 \text { Tahun } \\
2018\end{array}$ \\
\hline
\end{tabular}




\begin{tabular}{|r|r|l|c|l|l|}
\hline Peringkat & No. & \multicolumn{1}{|c|}{ Nama Jurnal } & E-ISSN & \multicolumn{1}{c|}{ Penerbit } & \multicolumn{1}{c|}{ Keterangan } \\
\hline & 28 & $\begin{array}{l}\text { Riyadhoh: Jurnal } \\
\text { Pendidikan } \\
\text { Olahraga }\end{array}$ & 26562936 & $\begin{array}{l}\text { UPT Publikasi } \\
\text { dan Pengelolaan } \\
\text { Jurnal, } \\
\text { Universitas Islam } \\
\text { Kalimantan }\end{array}$ & $\begin{array}{l}\text { Usulan Baru } \\
\text { mulai Volume 1 } \\
\text { Nomor 1 Tahun } \\
2018\end{array}$ \\
& 29 & $\begin{array}{l}\text { Unistek: Jurnal } \\
\text { Pendidikan dan } \\
\text { Aplikasi Industri }\end{array}$ & 27160416 & $\begin{array}{l}\text { Universitas Islam } \\
\text { Syekh Yusuf } \\
\text { Tangerang }\end{array}$ & $\begin{array}{l}\text { Usulan Baru } \\
\text { mulai Volume 5 } \\
\text { Nomor 1 Tahun } \\
\text { 2018 }\end{array}$ \\
\hline
\end{tabular}

MENTERI RISET DAN TEKNOLOGI/

KEPALA BADAN RISET DAN INOVASI NASIONAL REPUBLIK INDONESIA,

ttd.

BAMBANG P.S. BRODJONEGORO

Salinan sesuai dengan aslinya KEMENTERIAN RISET DAN TEKNOLOGI/ BADAN RISET DAN INOVASI NASIONAL Sekretariat Kementerian/Sekretariat Utama oGI/B 柏

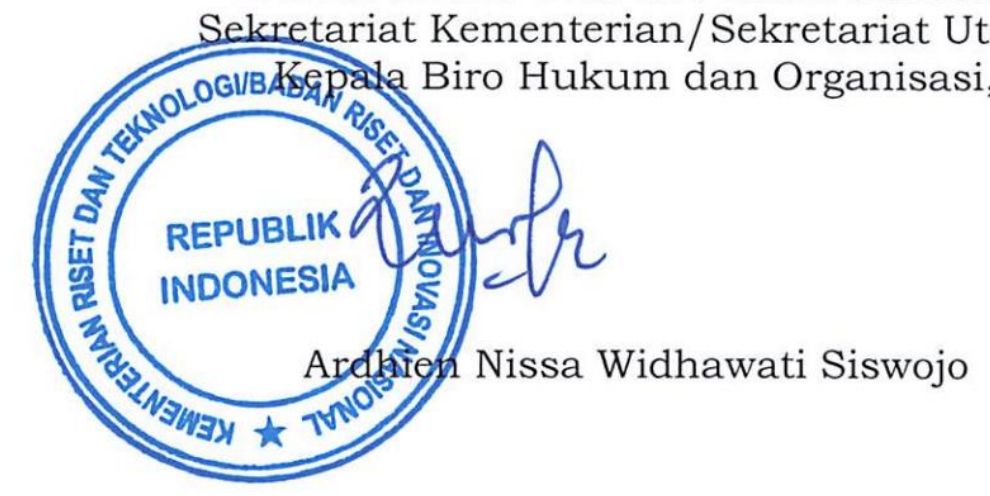




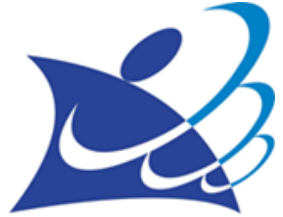

RISTEK-BRIN

KEMENTERIAN RISET DAN TEKNOLOGI/BADAN RISET

DAN INOVASI NASIONAL

DEPUTI BIDANG PENGUATAN RISET DAN PENGEMBANGAN

Gedung B.J.Habibie Lantai 19 - 20, Jalan M.H. Thamrin No. 8, Jakarta 10340

Telepon 021-3162222 Ext. 9702, 9782, 9707; Faksimile 021-3101728

Nomor $\quad:$ B/804/E5/E5.2.1/2019

Jakarta, 3 April 2020

Lampiran $\quad: 1$ (satu) Berkas

Perihal : Pemberitahuan Hasil Akreditasi Jurnal Ilmiah

Periode I Tahun 2020

Kepada Yth.

1. Pimpinan Perguruan Tinggi

2. Koordinator LL Dikti I s.d. XIV

3. Ketua Himpunan Profesi

4. Pengelola Jurnal Ilmiah

di seluruh Indonesia

Dengan hormat,

Sehubungan dengan hasil Akreditasi Jurnal Ilmiah Periode I Tahun 2020 dan telah diterbitkannya Surat Keputusan Menteri Riset dan Teknologi/Badan Riset dan Inovasi Nasional Nomor 85/M/KPT/2020, tanggal 01 April 2020, dengan hormat bersama ini kami sampaikan hasil akreditasi sebagaimana terlampir. Adapun ketentuan penerbitan sertifikat akreditasi sebagai berikut:

1. Bagi usulan akreditasi baru maka sertifikat akreditasi akan diterbitkan dan diberikan kepada pengelola jurnal.

2. Bagi usulan akreditasi ulang yang hasil akreditasi naik peringkat maka sertifikat akreditasi akan diterbitkan dan diberikan kepada pengelola jurnal.

3. Bagi usulan akreditasi ulang yang hasil akreditasi peringkatnya tetap dan telah memiliki sertifikat yang masih berlaku masa akreditasi, maka sertifikat baru tidak akan diterbitkan, dan sertifikat sebelumnya dapat digunakan sampai berakhir masa berlaku.

4. Bagi pengelola yang sudah terakreditasi dan namanya tercantum dalam SK sebelumnya serta belum memiliki sertifikat dapat meminta sertifikat terdahulu.

5. Penerbitan sertifikat dilakukan secara bertahap paling cepat 2 minggu setelah pengumuman ini dan dilakukan pemutakhiran data di laman : http://sinta2.ristekbrin.go.id/journals, penyerahan sertifikat dilakukan secara bertahap dapat diunduh langsung melalui akun pengusul di laman: http://arjuna.ristekbrin.go.id/ mulai tanggal 6 Juni 2020.

6. Bagi usulan yang ditolak administrasi dan usulan baru bisa mengajukan kembali melalui http://arjuna.ristekbrin.go.id/.

Atas perhatian dan kerja sama yang baik, kami ucapkan terima kasih.

Direktur Pengelolaan Kekayaan Intelektual

ttd

Heri Hermansyah

NIP. 197601181999031002

Tembusan :

Plt. Deputi Bidang Penguatan Riset dan Pengembangan 


\title{
MENTERI RISET DAN TEKNOLOGI/ KEPALA BADAN RISET DAN INOVASI NASIONAL REPUBLIK INDONESIA
}

\author{
KEPUTUSAN MENTERI RISET DAN TEKNOLOGI/ \\ KEPALA BADAN RISET DAN INOVASI NASIONAL \\ REPUBLIK INDONESIA
}

NOMOR 85/M/KPT/2020

TENTANG

PERINGKAT AKREDITASI JURNAL ILMIAH PERIODE I

TAHUN 2020

MENTERI RISET DAN TEKNOLOGI/

KEPALA BADAN RISET DAN INOVASI NASIONAL

REPUBLIK INDONESIA,

Menimbang : a. bahwa dalam rangka pembinaan dalam penyelenggaraan ilmu pengetahuan dan teknologi serta untuk meningkatkan relevansi, kuantitas, dan kualitas publikasi ilmiah ilmuwan Indonesia untuk mendukung daya saing bangsa diperlukan peringkat akreditasi jurnal ilmiah;

b. bahwa berdasarkan hasil akreditasi jurnal ilmiah yang ditetapkan oleh Tim Akreditasi Jurnal Ilmiah Kementerian Riset dan Teknologi/Badan Riset dan Inovasi Nasional pada tanggal 26 Maret 2020, telah diperoleh Peringkat Akreditasi Jurnal Ilmiah Periode I Tahun 2020;

c. bahwa berdasarkan pertimbangan sebagaimana dimaksud dalam huruf a dan huruf $b$, perlu menetapkan Keputusan Menteri Riset dan Teknologi/Kepala Badan Riset dan Inovasi Nasional tentang Peringkat Akreditasi Jurnal Ilmiah Periode I Tahun 2020;

Mengingat $: 1$. Undang-Undang Nomor 12 Tahun 2012 tentang Pendidikan Tinggi (Lembaran Negara Republik Indonesia Tahun 2012 Nomor 158, tambahan Lembaran Negara Republik Indonesia Nomor 5336); 
2. Undang-Undang Nomor 11 Tahun 2019 tentang Sistem Nasional Ilmu Pengetahuan dan Teknologi (Lembaran Negara Republik Indonesia Tahun 2019 Nomor 148, Tambahan Lembaran Negara Republik Indonesia, Tambahan Lembaran Negara Republik Indonesia Nomor 6374);

3. Peraturan Pemerintah Nomor 4 Tahun 2014 tentang Penyelenggaraan Pendidikan dan Pengelolaan Perguruan Tinggi (Lembaran Negara Republik Indonesia Tahun 2014 Nomor 16, Tambahan Lembaran Negara Republik Indonesia Nomor 5500);

4. Peraturan Presiden Nomor 50 Tahun 2020 tentang Kementerian Riset dan Teknologi (Lembaran Negara Republik Indonesia Tahun 2020 Nomor 89);

5. Keputusan Presiden Nomor 113/P Tahun 2019 tentang Pembentukan Kementerian Negara dan Pengangkatan Menteri Negara Kabinet Indonesia Maju Periode Tahun 20192024;

\section{MEMUTUSKAN:}

Menetapkan : KEPUTUSAN MENTERI RISET DAN TEKNOLOGI/KEPALA BADAN RISET DAN INOVASI NASIONAL TENTANG PERINGKAT AKREDITASI JURNAL ILMIAH PERIODE I TAHUN 2020.

KESATU : Menetapkan Peringkat Akreditasi Jurnal Ilmiah Periode I Tahun 2020 sebagaimana tercantum dalam Lampiran yang merupakan bagian yang tidak terpisahkan dari Keputusan Menteri/Kepala Badan ini.

KEDUA : Akreditasi Jurnal Ilmiah sebagaimana dimaksud dalam Diktum KESATU berlaku selama 5 (lima) tahun mulai dari nomor dan tahun sebagaimana tercantum dalam Lampiran yang merupakan bagian yang tidak terpisahkan dari Keputusan Menteri/Kepala Badan ini. 
KETIGA : Setiap jurnal ilmiah wajib mencantumkan masa berlaku akreditasi di dalam website jurnal dengan menuliskan tanggal penetapan dan tanggal akhir masa berlaku akreditasi.

KEEMPAT : Keputusan Menteri/Kepala Badan ini mulai berlaku pada tanggal ditetapkan.

Ditetapkan di Jakarta

pada tanggal 1 April 2020

MENTERI RISET DAN TEKNOLOGI/

KEPALA BADAN RISET DAN INOVASI

NASIONAL REPUBLIK INDONESIA,

ttd.

BAMBANG P.S. BRODJONEGORO

Salinan sesuai dengan aslinya KEMENTERIAN RISET DAN TEKNOLOGI/

BADAN RISET DAN INOVASI NASIONAL

Sekretariat Kementerian/Sekretariat Utama

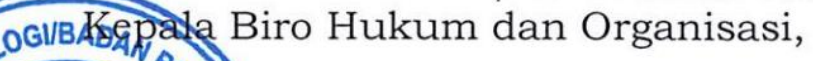


KEPUTUSAN MENTERI RISET DAN TEKNOLOGI/

KEPALA BADAN RISET DAN INOVASI NASIONAL REPUBLIK INDONESIA

NOMOR 85/M/KPT/2020

TENTANG

PERINGKAT AKREDITASI JURNAL ILMIAH

PERIODE I TAHUN 2020

PERINGKAT AKREDITASI JURNAL ILMIAH PERIODE 1 TAHUN 2020

\begin{tabular}{|c|c|c|c|c|c|}
\hline Peringkat & No. & Nama Jurnal & E-ISSN & Penerbit & Keterangan \\
\hline \multirow[t]{5}{*}{1} & $\overline{1}$ & $\begin{array}{l}\text { Bulletin of Chemical } \\
\text { Reaction } \\
\text { Engineering \& } \\
\text { Catalysis }\end{array}$ & 19782993 & $\begin{array}{l}\text { Departement of } \\
\text { Chemical } \\
\text { Engineering, } \\
\text { Diponegoro } \\
\text { University }\end{array}$ & $\begin{array}{l}\text { Reakreditasi } \\
\text { Tetap di } \\
\text { Peringkat } 1 \text { mulai } \\
\text { Volume } 15 \\
\text { Nomor } 1 \text { Tahun } \\
2020\end{array}$ \\
\hline & 2 & $\begin{array}{l}\text { Indonesian } \\
\text { Aquaculture Journal }\end{array}$ & 25026577 & $\begin{array}{l}\text { The Center for } \\
\text { Fisheries } \\
\text { Research, } \\
\text { Indonesian } \\
\text { Ministry of Marine } \\
\text { Affairs and } \\
\text { Fisheries }\end{array}$ & $\begin{array}{l}\text { Reakreditasi } \\
\text { Tetap di } \\
\text { Peringkat } 1 \text { mulai } \\
\text { Volume } 14 \\
\text { Nomor } 2 \text { Tahun } \\
2019\end{array}$ \\
\hline & 3 & $\begin{array}{l}\text { Indonesian Journal } \\
\text { of Chemistry }\end{array}$ & 24601578 & $\begin{array}{l}\text { Chemistry } \\
\text { Department, } \\
\text { Faculty of } \\
\text { Mathematics and } \\
\text { Natural Sciences, } \\
\text { Universitas } \\
\text { Gadjah Mada }\end{array}$ & $\begin{array}{l}\text { Reakreditasi } \\
\text { Tetap di } \\
\text { Peringkat } 1 \text { mulai } \\
\text { Volume } 20 \\
\text { Nomor } 1 \text { Tahun } \\
2020\end{array}$ \\
\hline & 4 & $\begin{array}{l}\text { Jurnal Ilmu Ternak } \\
\text { dan Veteriner }\end{array}$ & $2252696 X$ & $\begin{array}{l}\text { Indonesian } \\
\text { Center for Animal } \\
\text { Research and } \\
\text { Development }\end{array}$ & $\begin{array}{l}\text { Reakreditasi } \\
\text { Tetap di } \\
\text { Peringkat } 1 \text { mulai } \\
\text { Volume } 24 \\
\text { Nomor } 4 \text { Tahun } \\
2020 \\
\end{array}$ \\
\hline & 5 & $\begin{array}{l}\text { Kesmas: National } \\
\text { Public Health } \\
\text { Journal }\end{array}$ & 24600601 & $\begin{array}{l}\text { Fakultas } \\
\text { Kesehatan } \\
\text { Masyarakat } \\
\text { Universitas } \\
\text { Indonesia }\end{array}$ & $\begin{array}{l}\text { Reakreditasi } \\
\text { Tetap di } \\
\text { Peringkat } 1 \text { mulai } \\
\text { Volume } 14 \\
\text { Nomor } 2 \text { Tahun } \\
2019\end{array}$ \\
\hline
\end{tabular}

6. Molekul ... 


\begin{tabular}{|c|c|c|c|c|c|}
\hline \begin{tabular}{|l|} 
Peringkat \\
\end{tabular} & No. & Nama Jurnal & E-ISSN & Penerbit & Keterangan \\
\hline & 6 & $\begin{array}{l}\text { Molekul: Jurnal } \\
\text { Ilmiah Kimia }\end{array}$ & 25030310 & $\begin{array}{l}\text { Jurusan Kimia } \\
\text { FMIPA } \\
\text { Universitas } \\
\text { Jenderal } \\
\text { Soedirman }\end{array}$ & $\begin{array}{l}\text { Reakreditasi } \\
\text { Tetap di } \\
\text { Peringkat } 1 \text { mulai } \\
\text { Volume } 14 \\
\text { Nomor } 2 \text { Tahun } \\
2019\end{array}$ \\
\hline & 7 & $\begin{array}{l}\text { SAINS TANAH - } \\
\text { Journal of Soil } \\
\text { Science and } \\
\text { Agroclimatology }\end{array}$ & 23561424 & $\begin{array}{l}\text { Department of } \\
\text { Soil Science, } \\
\text { Faculty of } \\
\text { Agriculture, } \\
\text { Universitas } \\
\text { Sebelas Maret }\end{array}$ & $\begin{array}{l}\text { Reakreditasi } \\
\text { Tetap di } \\
\text { Peringkat } 1 \text { mulai } \\
\text { Volume } 15 \\
\text { Nomor } 1 \text { Tahun } \\
2018\end{array}$ \\
\hline \multirow[t]{5}{*}{2} & 1 & $\begin{array}{l}\text { Advances in Food } \\
\text { Science, Sustainable } \\
\text { Agriculture and } \\
\text { Agroindustrial } \\
\text { Engineering } \\
\text { (AFSSAAE) }\end{array}$ & 26225921 & $\begin{array}{l}\text { Universitas } \\
\text { Brawijaya }\end{array}$ & $\begin{array}{l}\text { Usulan Baru } \\
\text { mulai Volume } 1 \\
\text { Nomor } 1 \text { Tahun } \\
2018\end{array}$ \\
\hline & 2 & $\begin{array}{l}\text { Al Quds: Jurnal } \\
\text { Studi Alquran dan } \\
\text { Hadis }\end{array}$ & 25803190 & $\begin{array}{l}\text { Institut Agama } \\
\text { Islam Negeri } \\
\text { (IAIN) Curup }\end{array}$ & $\begin{array}{l}\text { Reakreditasi Naik } \\
\text { Peringkat dari } \\
\text { Peringkat } 3 \text { ke } \\
\text { Peringkat } 2 \text { mulai } \\
\text { Volume } 3 \text { Nomor } \\
2 \text { Tahun } 2019 \\
\end{array}$ \\
\hline & 3 & $\begin{array}{l}\text { Al-Bidayah: Jurnal } \\
\text { Pendidikan Dasar } \\
\text { Islam }\end{array}$ & 25493388 & $\begin{array}{l}\text { Program Studi } \\
\text { Pendidikan Guru } \\
\text { Madrasah } \\
\text { Ibtidaiyah } \\
\text { Fakultas Ilmu } \\
\text { Tarbiyah dan } \\
\text { Keguruan, } \\
\text { Universitas Islam } \\
\text { Negeri Sunan } \\
\text { Kalijaga } \\
\text { Yogyakarta } \\
\end{array}$ & $\begin{array}{l}\text { Reakreditasi Naik } \\
\text { Peringkat dari } \\
\text { Peringkat } 3 \mathrm{ke} \\
\text { Peringkat } 2 \text { mulai } \\
\text { Volume } 11 \\
\text { Nomor } 2 \text { Tahun } \\
2019\end{array}$ \\
\hline & 4 & $\begin{array}{l}\text { Al-Istinbath: Jurnal } \\
\text { Hukum Islam }\end{array}$ & 25483382 & $\begin{array}{l}\text { Institut Agama } \\
\text { Islam Negeri } \\
\text { (IAIN)) Curup }\end{array}$ & $\begin{array}{l}\text { Reakreditasi Naik } \\
\text { Peringkat dari } \\
\text { Peringkat } 3 \text { ke } \\
\text { Peringkat } 2 \text { mulai } \\
\text { Volume } 4 \text { Nomor } \\
2 \text { Tahun } 2019\end{array}$ \\
\hline & 5 & Amerta & 25498908 & $\begin{array}{l}\text { Pusat Penelitian } \\
\text { Arkeologi } \\
\text { Nasional }\end{array}$ & $\begin{array}{l}\text { Reakreditasi } \\
\text { Tetap di } \\
\text { Peringkat } 2 \text { mulai } \\
\text { Volume } 37 \\
\text { Nomor } 2 \text { Tahun } \\
2019\end{array}$ \\
\hline
\end{tabular}

6. Analisa ... 


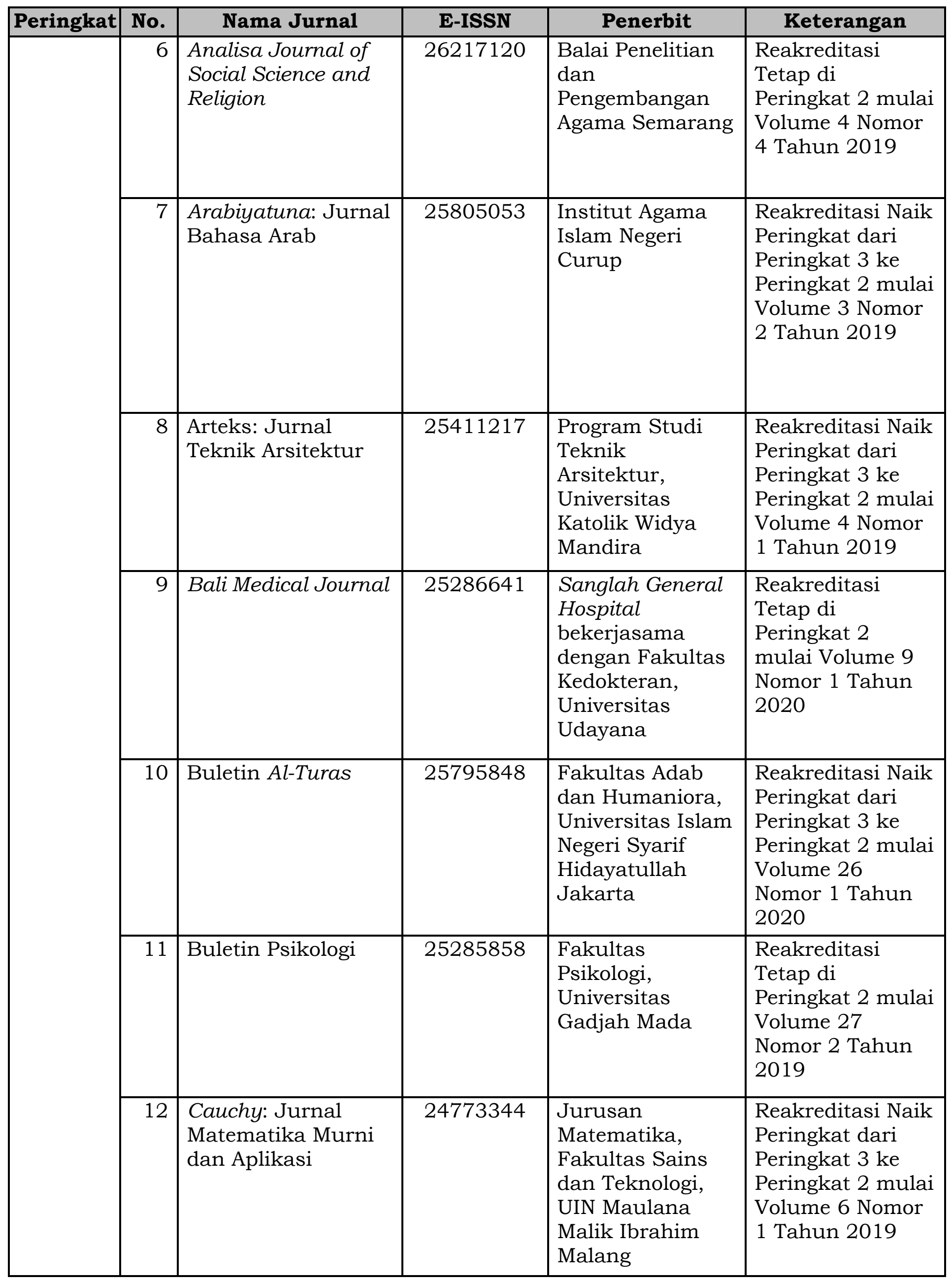




\begin{tabular}{|c|c|c|c|c|c|}
\hline \multirow[t]{9}{*}{ Peringkat } & No. & Nama Jurnal & E-ISSN & Penerbit & Keterangan \\
\hline & 13 & $\begin{array}{l}\text { Communication in } \\
\text { Biomathematical } \\
\text { Sciences }\end{array}$ & 25492896 & $\begin{array}{l}\text { Indonesian } \\
\text { Biomathematical } \\
\text { Society }\end{array}$ & $\begin{array}{l}\text { Usulan Baru } \\
\text { mulai Volume } 1 \\
\text { Nomor } 1 \text { Tahun } \\
2017\end{array}$ \\
\hline & 14 & $\begin{array}{l}\text { Communicatus: } \\
\text { Jurnal Ilmu } \\
\text { Komunikasi }\end{array}$ & 25498452 & $\begin{array}{l}\text { Fakultas Dakwah } \\
\text { dan Komunikasi, } \\
\text { UIN Sunan } \\
\text { Gunung Djati } \\
\text { Bandung }\end{array}$ & $\begin{array}{l}\text { Reakreditasi Naik } \\
\text { Peringkat dari } \\
\text { Peringkat } 3 \text { ke } \\
\text { Peringkat } 2 \text { mulai } \\
\text { Volume } 3 \text { Nomor } \\
2 \text { Tahun } 2019\end{array}$ \\
\hline & 15 & $\begin{array}{l}\text { Indigenous: Jurnal } \\
\text { Ilmiah Psikologi }\end{array}$ & $2541450 X$ & $\begin{array}{l}\text { Fakultas } \\
\text { Psikologi, } \\
\text { Universitas } \\
\text { Muhammadiyah } \\
\text { Surakarta }\end{array}$ & $\begin{array}{l}\text { Reakreditasi Naik } \\
\text { Peringkat dari } \\
\text { Peringkat } 4 \text { ke } \\
\text { Peringkat } 2 \text { mulai } \\
\text { Volume } 4 \text { Nomor } \\
2 \text { Tahun } 2019 \\
\end{array}$ \\
\hline & 16 & $\begin{array}{l}\text { Indonesian Fisheries } \\
\text { Research Journal }\end{array}$ & 25026569 & $\begin{array}{l}\text { The Center for } \\
\text { Fisheries } \\
\text { Research, } \\
\text { Indonesian } \\
\text { Ministry of Marine } \\
\text { Affairs and } \\
\text { Fisheries }\end{array}$ & $\begin{array}{l}\text { Reakreditasi } \\
\text { Tetap di } \\
\text { Peringkat } 2 \text { mulai } \\
\text { Volume } 25 \\
\text { Nomor } 2 \text { Tahun } \\
2019\end{array}$ \\
\hline & 17 & $\begin{array}{l}\text { Intensif: Jurnal } \\
\text { Penelitian dan } \\
\text { Penerapan } \\
\text { Teknologi Sistem } \\
\text { Informasi }\end{array}$ & 25496824 & $\begin{array}{l}\text { Universitas } \\
\text { Nusantara PGRI } \\
\text { Kediri }\end{array}$ & $\begin{array}{l}\text { Reakreditasi Naik } \\
\text { Peringkat dari } \\
\text { Peringkat } 3 \mathrm{ke} \\
\text { Peringkat } 2 \text { mulai } \\
\text { Volume } 4 \text { Nomor } \\
1 \text { Tahun } 2020\end{array}$ \\
\hline & 18 & $\begin{array}{l}\text { International } \\
\text { Journal of Islamic } \\
\text { Business and } \\
\text { Economics (IJIBEC) }\end{array}$ & $2615420 X$ & $\begin{array}{l}\text { Fakultas } \\
\text { Ekonomi dan } \\
\text { Bisnis Islam } \\
\text { (FEBI) IAIN } \\
\text { Pekalongan } \\
\text { Kerjasama MES } \\
\text { dan IAEI }\end{array}$ & $\begin{array}{l}\text { Reakreditasi Naik } \\
\text { Peringkat dari } \\
\text { Peringkat } 3 \mathrm{ke} \\
\text { Peringkat } 2 \text { mulai } \\
\text { Volume } 3 \text { Nomor } \\
2 \text { Tahun } 2019\end{array}$ \\
\hline & 19 & $\begin{array}{l}\text { JDM (Jurnal } \\
\text { Dinamika } \\
\text { Manajemen) }\end{array}$ & 23375434 & $\begin{array}{l}\text { Universitas } \\
\text { Negeri Semarang }\end{array}$ & $\begin{array}{l}\text { Reakreditasi } \\
\text { Tetap di } \\
\text { Peringkat } 2 \text { mulai } \\
\text { Volume } 10 \\
\text { Nomor } 2 \text { Tahun } \\
2019\end{array}$ \\
\hline & 20 & $\begin{array}{l}\text { JIPF (Jurnal Ilmu } \\
\text { Pendidikan Fisika) }\end{array}$ & 24778451 & $\begin{array}{l}\text { Institute of } \\
\text { Managing and } \\
\text { Publishing of } \\
\text { Scientific } \\
\text { Journals STKIP } \\
\text { Singkawang }\end{array}$ & $\begin{array}{l}\text { Reakreditasi Naik } \\
\text { Peringkat dari } \\
\text { Peringkat } 3 \text { ke } \\
\text { Peringkat } 2 \text { mulai } \\
\text { Volume } 5 \text { Nomor } \\
1 \text { Tahun } 2020\end{array}$ \\
\hline
\end{tabular}




\begin{tabular}{|c|c|c|c|c|c|}
\hline \begin{tabular}{|l|} 
Peringkat \\
\end{tabular} & No. & Nama Jurnal & E-ISSN & Penerbit & Keterangan \\
\hline \multirow{8}{*}{ | } & 21 & $\begin{array}{l}\text { Journal of the Civil } \\
\text { Engineering Forum }\end{array}$ & 25495925 & $\begin{array}{l}\text { Departemen } \\
\text { Teknik Sipil dan } \\
\text { Lingkungan } \\
\text { Universitas } \\
\text { Gadjah Mada }\end{array}$ & $\begin{array}{l}\text { Reakreditasi } \\
\text { Tetap di } \\
\text { Peringkat } 2 \text { mulai } \\
\text { Volume } 6 \text { Nomor } \\
1 \text { Tahun } 2020\end{array}$ \\
\hline & 22 & $\begin{array}{l}\text { Jurnal Ekonomi } \\
\text { dan Keuangan } \\
\text { Islam }\end{array}$ & 26146908 & $\begin{array}{l}\text { Pusat Pengkajian } \\
\text { dan } \\
\text { Pengembangan } \\
\text { Ekonomi Islam } \\
\text { (P3EI), Fakultas } \\
\text { Ekonomi, } \\
\text { Universitas Islam } \\
\text { Indonesia }\end{array}$ & $\begin{array}{l}\text { Reakreditasi Naik } \\
\text { Peringkat dari } \\
\text { Peringkat } 3 \mathrm{ke} \\
\text { Peringkat } 2 \text { mulai } \\
\text { Volume } 6 \text { Nomor } \\
1 \text { Tahun } 2020\end{array}$ \\
\hline & 23 & $\begin{array}{l}\text { Jurnal Fitopatologi } \\
\text { Indonesia }\end{array}$ & 23392479 & $\begin{array}{l}\text { Perhimpunan } \\
\text { Fitopatologi } \\
\text { Indonesia }\end{array}$ & $\begin{array}{l}\text { Reakreditasi } \\
\text { Tetap di } \\
\text { Peringkat } 2 \text { mulai } \\
\text { Volume } 16 \\
\text { Nomor } 1 \text { Tahun } \\
2020\end{array}$ \\
\hline & 24 & $\begin{array}{l}\text { Jurnal Ilmiah } \\
\text { Akuntansi dan } \\
\text { Bisnis }\end{array}$ & 23031018 & $\begin{array}{l}\text { Fakultas } \\
\text { Ekonomi dan } \\
\text { Bisnis } \\
\text { Universitas } \\
\text { Udayana }\end{array}$ & $\begin{array}{l}\text { Reakreditasi } \\
\text { Tetap di } \\
\text { Peringkat } 2 \text { mulai } \\
\text { Volume } 15 \\
\text { Nomor } 1 \text { Tahun } \\
2020\end{array}$ \\
\hline & 25 & $\begin{array}{l}\text { Jurnal Ilmiah } \\
\text { Al-Syir'ah }\end{array}$ & 25280368 & $\begin{array}{l}\text { Fakultas Syariah } \\
\text { IAIN Manado }\end{array}$ & $\begin{array}{l}\text { Reakreditasi Naik } \\
\text { Peringkat dari } \\
\text { Peringkat } 3 \text { ke } \\
\text { Peringkat } 2 \text { mulai } \\
\text { Volume } 17 \\
\text { Nomor } 2 \text { Tahun } \\
2019\end{array}$ \\
\hline & 26 & $\begin{array}{l}\text { Jurnal Ilmu } \\
\text { Kehutanan }\end{array}$ & 24773751 & $\begin{array}{l}\text { Universitas } \\
\text { Gadjah Mada }\end{array}$ & $\begin{array}{l}\text { Reakreditasi } \\
\text { Tetap di } \\
\text { Peringkat } 2 \text { mulai } \\
\text { Volume } 13 \\
\text { Nomor } 2 \text { Tahun } \\
2019\end{array}$ \\
\hline & 27 & $\begin{array}{l}\text { Jurnal Ilmu } \\
\text { Komunikasi }\end{array}$ & 25488643 & $\begin{array}{l}\text { Prodi Ilmu } \\
\text { Komunikasi } \\
\text { FISIP Universitas } \\
\text { Atma Jaya } \\
\text { Yogyakarta }\end{array}$ & $\begin{array}{l}\text { Reakreditasi } \\
\text { Tetap di } \\
\text { Peringkat } 2 \text { mulai } \\
\text { Volume } 16 \\
\text { Nomor } 2 \text { Tahun } \\
2019\end{array}$ \\
\hline & 28 & $\begin{array}{l}\text { Jurnal Iqra': Kajian } \\
\text { Ilmu Pendidikan }\end{array}$ & 25487892 & $\begin{array}{l}\text { Fakultas } \\
\text { Tarbiyah IAI } \\
\text { Ma'arif NU Metro } \\
\text { Lampung }\end{array}$ & $\begin{array}{l}\text { Reakreditasi Naik } \\
\text { Peringkat dari } \\
\text { Peringkat } 3 \text { ke } \\
\text { Peringkat } 2 \text { mulai } \\
\text { Volume } 4 \text { Nomor } \\
2 \text { Tahun } 2019\end{array}$ \\
\hline
\end{tabular}




\begin{tabular}{|c|c|c|c|c|c|}
\hline Peringkat & No. & Nama Jurnal & E-ISSN & Penerbit & Keterangan \\
\hline \multirow{8}{*}{ 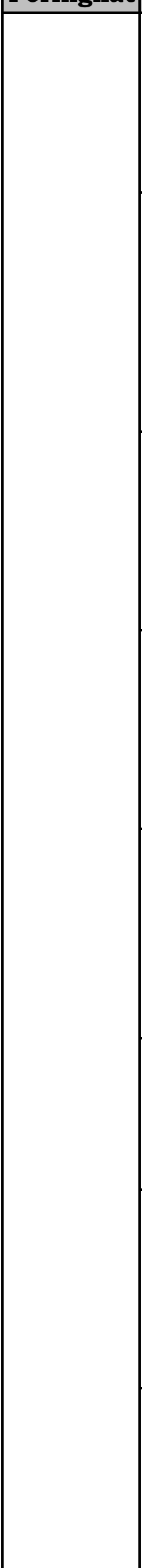 } & 29 & $\begin{array}{l}\text { Jurnal } \\
\text { Jurisprudence }\end{array}$ & 25495615 & $\begin{array}{l}\text { Program Magister } \\
\text { Ilmu Hukum, } \\
\text { Universitas } \\
\text { Muhammadiyah } \\
\text { Surakarta }\end{array}$ & $\begin{array}{l}\text { Reakreditasi Naik } \\
\text { Peringkat dari } \\
\text { Peringkat } 4 \text { ke } \\
\text { Peringkat } 2 \text { mulai } \\
\text { Volume } 9 \text { Nomor } \\
2 \text { Tahun } 2019 \\
\end{array}$ \\
\hline & 30 & $\begin{array}{l}\text { Jurnal Kebijakan } \\
\text { dan Administrasi } \\
\text { Publik }\end{array}$ & 24774693 & $\begin{array}{l}\text { Magister } \\
\text { Administrasi } \\
\text { Publik (MAP) } \\
\text { Fakultas Ilmu } \\
\text { Sosial dan Ilmu } \\
\text { Politik } \\
\text { Universitas } \\
\text { Gadjah Mada } \\
\end{array}$ & $\begin{array}{l}\text { Reakreditasi } \\
\text { Tetap di } \\
\text { Peringkat } 2 \text { mulai } \\
\text { Volume } 23 \\
\text { Nomor } 2 \text { Tahun } \\
2019\end{array}$ \\
\hline & 31 & $\begin{array}{l}\text { Jurnal Kebijakan } \\
\text { Perikanan } \\
\text { Indonesia }\end{array}$ & 25026550 & $\begin{array}{l}\text { Pusat Riset } \\
\text { Perikanan } \\
\text { Kementerian } \\
\text { Kelautan dan } \\
\text { Perikanan }\end{array}$ & $\begin{array}{l}\text { Reakreditasi } \\
\text { Tetap di } \\
\text { Peringkat } 2 \text { mulai } \\
\text { Volume } 11 \\
\text { Nomor } 2 \text { Tahun } \\
2019\end{array}$ \\
\hline & 32 & $\begin{array}{l}\text { Jurnal Kelautan } \\
\text { Nasional }\end{array}$ & 26154579 & $\begin{array}{l}\text { Pusat Riset } \\
\text { Kelautan } \\
\text { Kementerian } \\
\text { Kelautan dan } \\
\text { Perikanan }\end{array}$ & $\begin{array}{l}\text { Reakreditasi } \\
\text { Tetap di } \\
\text { Peringkat } 2 \text { mulai } \\
\text { Volume } 14 \\
\text { Nomor } 3 \text { Tahun } \\
2019\end{array}$ \\
\hline & 33 & Jurnal Komunikasi & 25282727 & $\begin{array}{l}\text { Fakultas Ilmu } \\
\text { Komunikasi } \\
\text { Universitas } \\
\text { Tarumanagara }\end{array}$ & $\begin{array}{l}\text { Reakreditasi Naik } \\
\text { Peringkat dari } \\
\text { Peringkat } 3 \mathrm{ke} \\
\text { Peringkat } 2 \text { mulai } \\
\text { Volume } 11 \\
\text { Nomor } 2 \text { Tahun } \\
2019\end{array}$ \\
\hline & 34 & $\begin{array}{l}\text { Jurnal Manajemen } \\
\text { dan Pelayanan } \\
\text { Farmasi (Journal of } \\
\text { Management and } \\
\text { Pharmacy Practice) } \\
\end{array}$ & 24432946 & $\begin{array}{l}\text { Universitas } \\
\text { Gadjah Mada }\end{array}$ & $\begin{array}{l}\text { Reakreditasi } \\
\text { Tetap di } \\
\text { Peringkat } 2 \text { mulai } \\
\text { Volume } 9 \text { Nomor } \\
\text { 4 Tahun } 2019 \\
\end{array}$ \\
\hline & 35 & Jurnal Ners & 25025791 & $\begin{array}{l}\text { Fakultas } \\
\text { Keperawatan } \\
\text { Universitas } \\
\text { Airlangga }\end{array}$ & $\begin{array}{l}\text { Reakreditasi } \\
\text { Tetap di } \\
\text { Peringkat } 2 \text { mulai } \\
\text { Volume } 14 \\
\text { Nomor } 2 \text { Tahun } \\
2019\end{array}$ \\
\hline & 36 & $\begin{array}{l}\text { Jurnal Pendidikan } \\
\text { Jasmani dan } \\
\text { Olahraga }\end{array}$ & $2580071 \mathrm{X}$ & $\begin{array}{l}\text { Departemen } \\
\text { Pendidikan } \\
\text { Olahraga FPOK } \\
\text { Universitas } \\
\text { Pendidikan } \\
\text { Indonesia }\end{array}$ & $\begin{array}{l}\text { Reakreditasi Naik } \\
\text { Peringkat dari } \\
\text { Peringkat } 3 \text { ke } \\
\text { Peringkat } 2 \text { mulai } \\
\text { Volume } 4 \text { Nomor } \\
2 \text { Tahun } 2019\end{array}$ \\
\hline
\end{tabular}




\begin{tabular}{|c|c|c|c|c|c|}
\hline \begin{tabular}{|l|} 
Peringkat \\
\end{tabular} & No. & Nama Jurnal & E-ISSN & Penerbit & Keterangan \\
\hline & 37 & $\begin{array}{l}\text { Jurnal Pendidikan } \\
\text { Kedokteran } \\
\text { Indonesia: The } \\
\text { Indonesian Journal } \\
\text { of Medical Education }\end{array}$ & 26545810 & $\begin{array}{l}\text { Asosiasi Institusi } \\
\text { Pendidikan } \\
\text { Kedokteran } \\
\text { Indonesia }\end{array}$ & $\begin{array}{l}\text { Usulan Baru } \\
\text { mulai Volume } 3 \\
\text { Nomor } 1 \text { Tahun } \\
2019\end{array}$ \\
\hline & 38 & $\begin{array}{l}\text { Jurnal Pendidikan } \\
\text { Vokasi }\end{array}$ & 24769401 & $\begin{array}{l}\text { Asosiasi Dosen } \\
\text { dan Guru Vokasi } \\
\text { Indonesia dan } \\
\text { Program } \\
\text { Pascasarjana } \\
\text { Universitas } \\
\text { Negeri } \\
\text { Yogyakarta }\end{array}$ & $\begin{array}{l}\text { Reakreditasi } \\
\text { Tetap di } \\
\text { Peringkat } 2 \text { mulai } \\
\text { Volume } 9 \text { Nomor } \\
3 \text { Tahun } 2019\end{array}$ \\
\hline & 39 & $\begin{array}{l}\text { Jurnal Pengolahan } \\
\text { Hasil Perikanan } \\
\text { Indonesia }\end{array}$ & $2354886 \mathrm{X}$ & $\begin{array}{l}\text { Masyarakat } \\
\text { Pengolahan Hasil } \\
\text { Perikanan } \\
\text { Indonesia }\end{array}$ & $\begin{array}{l}\text { Reakreditasi } \\
\text { Tetap di } \\
\text { Peringkat } 2 \text { mulai } \\
\text { Volume } 2 \text { Nomor } \\
3 \text { Tahun } 2019\end{array}$ \\
\hline & 40 & $\begin{array}{l}\text { Jurnal Psikologi } \\
\text { Ulayat: Indonesian } \\
\text { Journal of } \\
\text { Indigenous } \\
\text { Psychology }\end{array}$ & 25801228 & $\begin{array}{l}\text { Konsorsium } \\
\text { Psikologi Ilmiah } \\
\text { Nusantara (KPIN) }\end{array}$ & $\begin{array}{l}\text { Reakreditasi Naik } \\
\text { Peringkat dari } \\
\text { Peringkat } 3 \text { ke } \\
\text { Peringkat } 2 \text { mulai } \\
\text { Volume } 6 \text { Nomor } \\
2 \text { Tahun } 2019\end{array}$ \\
\hline & 41 & $\begin{array}{l}\text { Jurnal Sain } \\
\text { Veteriner }\end{array}$ & 24073733 & $\begin{array}{l}\text { Universitas } \\
\text { Gadjah Mada }\end{array}$ & $\begin{array}{l}\text { Reakreditasi } \\
\text { Tetap di } \\
\text { Peringkat } 2 \text { mulai } \\
\text { Volume } 37 \\
\text { Nomor } 2 \text { Tahun } \\
2019\end{array}$ \\
\hline & 42 & $\begin{array}{l}\text { Jurnal SMaRT } \\
\text { (Studi Masyarakat } \\
\text { Religi dan Tradisi) }\end{array}$ & $2528553 X$ & $\begin{array}{l}\text { Balai Penelitian } \\
\text { dan } \\
\text { Pengembangan } \\
\text { Agama Semarang }\end{array}$ & $\begin{array}{l}\text { Reakreditasi } \\
\text { Tetap di } \\
\text { Peringkat } 2 \text { mulai } \\
\text { Volume } 5 \text { Nomor } \\
2 \text { Tahun } 2019 \\
\end{array}$ \\
\hline & 43 & $\begin{array}{l}\text { Jurnal Studi Ilmu- } \\
\text { Ilmu Al-Qur'an dan } \\
\text { Hadis }\end{array}$ & 25484737 & $\begin{array}{l}\text { Program Studi } \\
\text { Ilmu al-Qur'an } \\
\text { dan Tafsir UIN } \\
\text { Sunan Kalijaga } \\
\text { Yogyakarta }\end{array}$ & $\begin{array}{l}\text { Reakreditasi Naik } \\
\text { Peringkat dari } \\
\text { Peringkat } 3 \text { ke } \\
\text { Peringkat } 2 \text { mulai } \\
\text { Volume } 21 \\
\text { Nomor } 1 \text { Tahun } \\
2020\end{array}$ \\
\hline & 44 & $\begin{array}{l}\text { Knowledge } \\
\text { Engineering and } \\
\text { Data Science }\end{array}$ & 25974637 & $\begin{array}{l}\text { Jurusan Teknik } \\
\text { Elektro, Program } \\
\text { Studi Teknik } \\
\text { Informatika, } \\
\text { Universitas } \\
\text { Negeri Malang }\end{array}$ & $\begin{array}{l}\text { Usulan Baru } \\
\text { mulai Volume } 1 \\
\text { Nomor } 1 \text { Tahun } \\
2018\end{array}$ \\
\hline
\end{tabular}

45. Konseling ... 


\begin{tabular}{|c|c|c|c|c|c|}
\hline Peringkat & No. & Nama Jurnal & E-ISSN & Penerbit & Keterangan \\
\hline & 45 & $\begin{array}{l}\text { Konseling Religi } \\
\text { Jurnal Bimbingan } \\
\text { Konseling Islam }\end{array}$ & 24772100 & $\begin{array}{l}\text { Prodi Bimbingan } \\
\text { dan Konseling } \\
\text { Islam Jurusan } \\
\text { Dakwah dan } \\
\text { Komunikasi } \\
\text { STAIN Kudus }\end{array}$ & $\begin{array}{l}\text { Reakreditasi } \\
\text { Tetap di } \\
\text { Peringkat } 2 \text { mulai } \\
\text { Volume } 10 \\
\text { Nomor } 2 \text { Tahun } \\
2019\end{array}$ \\
\hline & 46 & $\begin{array}{l}\text { Majalah Kedokteran } \\
\text { Gigi Indonesia }\end{array}$ & 24422576 & $\begin{array}{l}\text { Fakultas } \\
\text { Kedokteran Gigi } \\
\text { Universitas } \\
\text { Gadjah Mada }\end{array}$ & $\begin{array}{l}\text { Reakreditasi } \\
\text { Tetap di } \\
\text { Peringkat } 2 \text { mulai } \\
\text { Volume } 5 \text { Nomor } \\
3 \text { Tahun } 2019\end{array}$ \\
\hline & 47 & $\begin{array}{l}\text { Majalah Obat } \\
\text { Tradisional }\end{array}$ & 24069086 & $\begin{array}{l}\text { Fakultas Farmasi } \\
\text { Universitas } \\
\text { Gadjah Mada }\end{array}$ & $\begin{array}{l}\text { Reakreditasi } \\
\text { Tetap di } \\
\text { Peringkat } 2 \text { mulai } \\
\text { Volume } 24 \\
\text { Nomor } 3 \text { Tahun } \\
2019\end{array}$ \\
\hline & 48 & Media Akuakultur & 25029460 & $\begin{array}{l}\text { Pusat Riset } \\
\text { Perikanan } \\
\text { Kementerian } \\
\text { Kelautan dan } \\
\text { Perikanan }\end{array}$ & $\begin{array}{l}\text { Reakreditasi } \\
\text { Tetap di } \\
\text { Peringkat } 2 \text { mulai } \\
\text { Volume } 14 \\
\text { Nomor } 2 \text { Tahun } \\
2019\end{array}$ \\
\hline & 49 & $\begin{array}{l}\text { MIX: Jurnal Ilmiah } \\
\text { Manajemen }\end{array}$ & 24605328 & $\begin{array}{l}\text { Universitas } \\
\text { Mercu Buana }\end{array}$ & $\begin{array}{l}\text { Reakreditasi } \\
\text { Tetap di } \\
\text { Peringkat } 2 \text { mulai } \\
\text { Volume } 10 \\
\text { Nomor } 1 \text { Tahun } \\
2020\end{array}$ \\
\hline & 50 & $\begin{array}{l}\text { Muwazah: Jurnal } \\
\text { Kajian Gender }\end{array}$ & 25025368 & $\begin{array}{l}\text { Institut Agama } \\
\text { Islam Negeri } \\
\text { Pekalongan }\end{array}$ & $\begin{array}{l}\text { Reakreditasi Naik } \\
\text { Peringkat dari } \\
\text { Peringkat } 3 \text { ke } \\
\text { Peringkat } 2 \text { mulai } \\
\text { Volume } 11 \\
\text { Nomor } 2 \text { Tahun } \\
2019\end{array}$ \\
\hline & 51 & $\begin{array}{l}\text { Signifikan: Jurnal } \\
\text { Ilmu Ekonomi }\end{array}$ & 24769223 & $\begin{array}{l}\text { Universitas Islam } \\
\text { Negeri Syarif } \\
\text { Hidayatullah } \\
\text { Jakarta }\end{array}$ & $\begin{array}{l}\text { Reakreditasi } \\
\text { Tetap di } \\
\text { Peringkat } 2 \text { mulai } \\
\text { Volume } 8 \text { Nomor } \\
2 \text { Tahun } 2019\end{array}$ \\
\hline & 52 & $\begin{array}{l}\text { Substantive Justice } \\
\text { International } \\
\text { Journal of Law }\end{array}$ & 25990462 & $\begin{array}{l}\text { Fakultas Hukum, } \\
\text { Universitas } \\
\text { Muslim } \\
\text { Indonesia }\end{array}$ & $\begin{array}{l}\text { Usulan Baru } \\
\text { mulai Volume } 1 \\
\text { Nomor } 1 \text { Tahun } \\
2018\end{array}$ \\
\hline & 53 & $\begin{array}{l}\text { Sustinere: Journal } \\
\text { of Environment and } \\
\text { Sustainability }\end{array}$ & 25491253 & $\begin{array}{l}\text { Centre for Science } \\
\text { and Technology, } \\
\text { IAIN Surakarta }\end{array}$ & $\begin{array}{l}\text { Usulan Baru } \\
\text { mulai Volume } 2 \\
\text { Nomor } 1 \text { Tahun } \\
2018\end{array}$ \\
\hline
\end{tabular}




\begin{tabular}{|c|c|c|c|c|c|}
\hline Peringkat & No. & Nama Jurnal & E-ISSN & Penerbit & Keterangan \\
\hline & 54 & Telematika & 24424528 & $\begin{array}{l}\text { Universitas } \\
\text { Amikom } \\
\text { Purwokerto }\end{array}$ & $\begin{array}{l}\text { Reakreditasi Naik } \\
\text { Peringkat dari } \\
\text { Peringkat } 3 \text { ke } \\
\text { Peringkat } 2 \text { mulai } \\
\text { Volume } 13 \\
\text { Nomor } 1 \text { Tahun } \\
2020\end{array}$ \\
\hline & 55 & $\begin{array}{l}\text { Wartazoa: Buletin } \\
\text { Ilmu Peternakan } \\
\text { dan Kesehatan } \\
\text { Hewan Indonesia }\end{array}$ & 23546832 & $\begin{array}{l}\text { Pusat Penelitian } \\
\text { dan } \\
\text { Pengembangan } \\
\text { Peternakan } \\
\text { Kementerian } \\
\text { Pertanian }\end{array}$ & $\begin{array}{l}\text { Reakreditasi } \\
\text { Tetap di } \\
\text { Peringkat } 2 \text { mulai } \\
\text { Volume } 29 \\
\text { Nomor } 4 \text { Tahun } \\
2019\end{array}$ \\
\hline \multirow[t]{7}{*}{3} & 1 & $\begin{array}{l}\text { Academia Praja: } \\
\text { Jurnal Ilmu Politik, } \\
\text { Pemerintahan dan } \\
\text { Administrasi Publik }\end{array}$ & 27159124 & $\begin{array}{l}\text { Universitas } \\
\text { Jenderal Achmad } \\
\text { Yani }\end{array}$ & $\begin{array}{l}\text { Usulan Baru } \\
\text { mulai Volume } 1 \\
\text { Nomor } 2 \text { Tahun } \\
2018\end{array}$ \\
\hline & 2 & $\begin{array}{l}\text { Aceh Journal of } \\
\text { Animal Science }\end{array}$ & 26228734 & $\begin{array}{l}\text { Fakultas } \\
\text { Kelautan dan } \\
\text { Perikanan } \\
\text { Universitas Syiah } \\
\text { Kuala }\end{array}$ & $\begin{array}{l}\text { Reakreditasi } \\
\text { Tetap di } \\
\text { Peringkat } 3 \text { mulai } \\
\text { Volume } 4 \text { Nomor } \\
2 \text { Tahun } 2019 \\
\end{array}$ \\
\hline & 3 & $\begin{array}{l}\text { Acta Biochimica } \\
\text { Indonesiana }\end{array}$ & 26543222 & $\begin{array}{l}\text { Perhimpunan } \\
\text { Biokimia dan } \\
\text { Biologi Molekuler } \\
\text { Indonesia }\end{array}$ & $\begin{array}{l}\text { Usulan Baru } \\
\text { mulai Volume } 1 \\
\text { Nomor } 1 \text { Tahun } \\
2018\end{array}$ \\
\hline & 4 & Acta Chimica Asiana & 25500503 & $\begin{array}{l}\text { Universitas } \\
\text { Mataram }\end{array}$ & $\begin{array}{l}\text { Usulan Baru } \\
\text { mulai Volume } 1 \\
\text { Nomor } 2 \text { Tahun } \\
2018\end{array}$ \\
\hline & 5 & $\begin{array}{l}\text { Agregat: Jurnal } \\
\text { Ekonomi dan Bisnis }\end{array}$ & 25497243 & $\begin{array}{l}\text { Fakultas } \\
\text { Ekonomi dan } \\
\text { Bisnis } \\
\text { Universitas } \\
\text { Muhammadiyah } \\
\text { Prof. DR. HAMKA }\end{array}$ & $\begin{array}{l}\text { Reakreditasi Naik } \\
\text { Peringkat dari } \\
\text { Peringkat } 4 \text { ke } \\
\text { Peringkat } 3 \text { mulai } \\
\text { Volume } 3 \text { Nomor } \\
2 \text { Tahun } 2019\end{array}$ \\
\hline & 6 & $\begin{array}{l}\text { Agrikan: Jurnal } \\
\text { Agribisnis } \\
\text { Perikanan }\end{array}$ & 26210193 & $\begin{array}{l}\text { Sekolah Tinggi } \\
\text { Ilmu Pertanian } \\
\text { Wuna Raha }\end{array}$ & $\begin{array}{l}\text { Reakreditasi Naik } \\
\text { Peringkat dari } \\
\text { Peringkat } 4 \text { ke } \\
\text { Peringkat } 3 \text { mulai } \\
\text { Volume } 12 \\
\text { Nomor } 2 \text { Tahun } \\
2019\end{array}$ \\
\hline & 7 & Agroteknika & 26853450 & $\begin{array}{l}\text { Politeknik } \\
\text { Pertaninan } \\
\text { Negeri } \\
\text { Payakumbuh }\end{array}$ & $\begin{array}{l}\text { Usulan Baru } \\
\text { mulai Volume } 1 \\
\text { Nomor } 1 \text { Tahun } \\
2018\end{array}$ \\
\hline
\end{tabular}




\begin{tabular}{|c|c|c|c|c|c|}
\hline \begin{tabular}{|l|} 
Peringkat \\
\end{tabular} & No. & Nama Jurnal & E-ISSN & Penerbit & Keterangan \\
\hline & 8 & $\begin{array}{l}\text { Agrovigor: Jurnal } \\
\text { Agroekoteknologi }\end{array}$ & 24770353 & $\begin{array}{l}\text { Program Studi } \\
\text { Agroekoteknologi, } \\
\text { Universitas } \\
\text { Trunojoyo } \\
\text { Madura }\end{array}$ & $\begin{array}{l}\text { Reakreditasi Naik } \\
\text { Peringkat dari } \\
\text { Peringkat } 4 \text { ke } \\
\text { Peringkat } 3 \text { mulai } \\
\text { Volume } 12 \\
\text { Nomor } 2 \text { Tahun } \\
2019\end{array}$ \\
\hline & 9 & $\begin{array}{l}\text { AJIS: Academic } \\
\text { Journal of Islamic } \\
\text { Studies }\end{array}$ & 25483285 & $\begin{array}{l}\text { Institut Agama } \\
\text { Islam Negeri } \\
\text { (IAIN) Curup }\end{array}$ & $\begin{array}{l}\text { Reakreditasi Naik } \\
\text { Peringkat dari } \\
\text { Peringkat } 4 \text { ke } \\
\text { Peringkat } 3 \text { mulai } \\
\text { Volume } 4 \text { Nomor } \\
2 \text { Tahun } 2019\end{array}$ \\
\hline & 10 & $\begin{array}{l}\text { Alchemy: Journal of } \\
\text { Chemistry }\end{array}$ & 24606871 & $\begin{array}{l}\text { Jurusan Kimia } \\
\text { Fakultas Sains } \\
\text { dan Teknologi } \\
\text { Universitas Islam } \\
\text { Negeri Maulana } \\
\text { Malik Ibrahim } \\
\text { Malang } \\
\end{array}$ & $\begin{array}{l}\text { Usulan Baru } \\
\text { mulai Volume } 6 \\
\text { Nomor } 1 \text { Tahun } \\
2018\end{array}$ \\
\hline & 11 & $\begin{array}{l}\text { Al-Falah: Journal of } \\
\text { Islamic Economics }\end{array}$ & 25483102 & $\begin{array}{l}\text { Institut Agama } \\
\text { Islam Negari } \\
\text { (IAIN), Curup- } \\
\text { Bengkulu }\end{array}$ & $\begin{array}{l}\text { Reakreditasi Naik } \\
\text { Peringkat dari } \\
\text { Peringkat } 4 \text { ke } \\
\text { Peringkat } 3 \text { mulai } \\
\text { Volume } 4 \text { Nomor } \\
2 \text { Tahun } 2019 \\
\end{array}$ \\
\hline & 12 & Al-Kimia & 25499335 & $\begin{array}{l}\text { Jurusan Kimia } \\
\text { Fak. Sains dan } \\
\text { Teknologi } \\
\text { Universitas Islam } \\
\text { Negeri Alauddin } \\
\text { Makassar }\end{array}$ & $\begin{array}{l}\text { Reakreditasi } \\
\text { Tetap di } \\
\text { Peringkat } 3 \text { mulai } \\
\text { Volume } 7 \text { Nomor } \\
2 \text { Tahun } 2019\end{array}$ \\
\hline & 13 & $\begin{array}{l}\text { Al-Tanzim: Jurnal } \\
\text { Manajemen } \\
\text { Pendidikan Islam }\end{array}$ & 25495720 & $\begin{array}{l}\text { FAI Universitas } \\
\text { Nurul Jadid }\end{array}$ & $\begin{array}{l}\text { Reakreditasi } \\
\text { Tetap di } \\
\text { Peringkat } 3 \text { mulai } \\
\text { Volume } 3 \text { Nomor } \\
2 \text { Tahun } 2019 \\
\end{array}$ \\
\hline & 14 & $\begin{array}{l}\text { Al-Tazkiah: Jurnal } \\
\text { Bimbingan dan } \\
\text { Konseling Islam }\end{array}$ & 25412663 & $\begin{array}{l}\text { Jurusan BKI, } \\
\text { Fakultas Dakwah } \\
\text { dan Ilmu } \\
\text { Komunikasi, } \\
\text { Universitas Islam } \\
\text { Negeri Mataram }\end{array}$ & $\begin{array}{l}\text { Usulan Baru } \\
\text { mulai Volume } 7 \\
\text { Nomor } 1 \text { Tahun } \\
2018\end{array}$ \\
\hline & 15 & $\begin{array}{l}\text { An-Nisbah: Jurnal } \\
\text { Ekonomi Syariah }\end{array}$ & 25495712 & $\begin{array}{l}\text { Fakultas } \\
\text { Ekonomi dan } \\
\text { Bisnis Islam } \\
\text { Institut Agama } \\
\text { Islam Negeri } \\
\text { Tulungagung }\end{array}$ & $\begin{array}{l}\text { Reakreditasi Naik } \\
\text { Peringkat dari } \\
\text { Peringkat } 4 \text { ke } \\
\text { Peringkat } 3 \text { mulai } \\
\text { Volume } 6 \text { Nomor } \\
2 \text { Tahun } 2019\end{array}$ \\
\hline
\end{tabular}




\begin{tabular}{|c|c|c|c|c|c|}
\hline \begin{tabular}{|l|} 
Peringkat \\
\end{tabular} & No. & Nama Jurnal & E-ISSN & Penerbit & Keterangan \\
\hline & 16 & $\begin{array}{l}\text { Asia Pacific Fraud } \\
\text { Journal }\end{array}$ & $2502695 X$ & $\begin{array}{l}\text { Association of } \\
\text { Certified Fraud } \\
\text { Examiners } \\
\text { Indonesia } \\
\text { Chapter }\end{array}$ & $\begin{array}{l}\text { Usulan Baru } \\
\text { mulai Volume } 3 \\
\text { Nomor } 1 \text { Tahun } \\
2018\end{array}$ \\
\hline & 17 & $\begin{array}{l}\text { At-Turas: Jurnal } \\
\text { Studi Keislaman }\end{array}$ & 24601063 & $\begin{array}{l}\text { Lembaga } \\
\text { Penerbitan, } \\
\text { Penelitian, dan } \\
\text { Pengabdian } \\
\text { kepada } \\
\text { Masyarakat } \\
\text { (LP3M) } \\
\text { Universitas Nurul } \\
\text { Jadid }\end{array}$ & $\begin{array}{l}\text { Reakreditasi } \\
\text { Tetap di } \\
\text { Peringkat } 3 \text { mulai } \\
\text { Volume } 6 \text { Nomor } \\
2 \text { Tahun } 2018\end{array}$ \\
\hline & 18 & $\begin{array}{l}\text { Bioedusains: Jurnal } \\
\text { Pendidikan Biologi } \\
\text { dan Sains }\end{array}$ & 25987453 & $\begin{array}{l}\text { Institut } \\
\text { Penelitian } \\
\text { Matematika, } \\
\text { Komputer, } \\
\text { Keperawatan, } \\
\text { Pendidikan dan } \\
\text { Ekonomi } \\
\text { (IPM2KPE) } \\
\end{array}$ & $\begin{array}{l}\text { Usulan Baru } \\
\text { mulai Volume } 1 \\
\text { Nomor } 1 \text { Tahun } \\
2018\end{array}$ \\
\hline & 19 & $\begin{array}{l}\text { BioLink (Jurnal } \\
\text { Biologi Lingkungan, } \\
\text { Industri, Kesehatan) }\end{array}$ & 25975269 & $\begin{array}{l}\text { Fakultas Biologi } \\
\text { Universitas } \\
\text { Medan Area }\end{array}$ & $\begin{array}{l}\text { Reakreditasi } \\
\text { Tetap di } \\
\text { Peringkat } 3 \text { mulai } \\
\text { Volume } 6 \text { Nomor } \\
2 \text { Tahun } 2020\end{array}$ \\
\hline & 20 & $\begin{array}{l}\text { Bioscientia } \\
\text { Medicina: Journal of } \\
\text { Biomedicine and } \\
\text { Translational } \\
\text { Research } \\
\end{array}$ & 25980580 & $\begin{array}{l}\text { Fakultas } \\
\text { Kedokteran } \\
\text { Universitas } \\
\text { Sriwijaya }\end{array}$ & $\begin{array}{l}\text { Usulan Baru } \\
\text { mulai Volume } 2 \\
\text { Nomor } 2 \text { Tahun } \\
2018\end{array}$ \\
\hline & 21 & $\begin{array}{l}\text { Bioscientist: Jurnal } \\
\text { Ilmiah Biologi }\end{array}$ & 26544571 & IKIP Mataram & $\begin{array}{l}\text { Usulan Baru } \\
\text { mulai Volume } 6 \\
\text { Nomor } 1 \text { Tahun } \\
2018\end{array}$ \\
\hline & 22 & $\begin{array}{l}\text { Caradde: Jurnal } \\
\text { Pengabdian Kepada } \\
\text { Masyarakat }\end{array}$ & 26217910 & $\begin{array}{l}\text { Institute for } \\
\text { Learning } \\
\text { Innovation and } \\
\text { Counseling }\end{array}$ & $\begin{array}{l}\text { Usulan Baru } \\
\text { mulai Volume } 1 \\
\text { Nomor } 1 \text { Tahun } \\
2018\end{array}$ \\
\hline & 23 & $\begin{array}{l}\text { Cheesa: Chemical } \\
\text { Engineering } \\
\text { Research Articles }\end{array}$ & 26152347 & $\begin{array}{l}\text { Universitas PGRI } \\
\text { Madiun }\end{array}$ & $\begin{array}{l}\text { Usulan Baru } \\
\text { mulai Volume } 1 \\
\text { Nomor } 1 \text { Tahun } \\
2018\end{array}$ \\
\hline & 24 & $\begin{array}{l}\text { Chemica Jurnal } \\
\text { Teknik Kimia }\end{array}$ & 23558776 & $\begin{array}{l}\text { Program Studi } \\
\text { Teknik Kimia, } \\
\text { Fakultas } \\
\text { Teknologi } \\
\text { Industri, } \\
\text { Universitas } \\
\text { Ahmad Dahlan }\end{array}$ & $\begin{array}{l}\text { Reakreditasi Naik } \\
\text { Peringkat dari } \\
\text { Peringkat } 4 \mathrm{ke} \\
\text { Peringkat } 3 \text { mulai } \\
\text { Volume } 6 \text { Nomor } \\
2 \text { Tahun } 2019\end{array}$ \\
\hline
\end{tabular}




\begin{tabular}{|c|c|c|c|c|c|}
\hline Peringkat & No. & Nama Jurnal & E-ISSN & Penerbit & Keterangan \\
\hline \multirow[t]{8}{*}{ 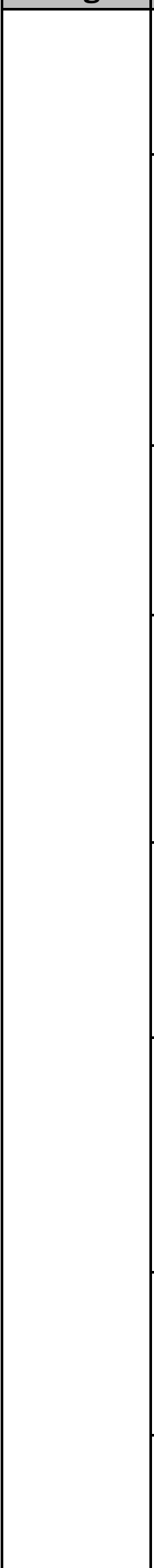 } & 25 & $\begin{array}{l}\text { Cropsaver: Journal } \\
\text { of Plant Protection }\end{array}$ & 26215756 & $\begin{array}{l}\text { Universitas } \\
\text { Padjadjaran }\end{array}$ & $\begin{array}{l}\text { Usulan Baru } \\
\text { mulai Volume } 1 \\
\text { Nomor } 1 \text { Tahun } \\
2018\end{array}$ \\
\hline & 26 & $\begin{array}{l}\text { Dayah: Journal of } \\
\text { Islamic Education }\end{array}$ & 26142694 & $\begin{array}{l}\text { Pusat Penelitian } \\
\text { dan Penerbitan, } \\
\text { Lembaga } \\
\text { Penelitian dan } \\
\text { Pengabdian } \\
\text { kepada } \\
\text { Masyarakat } \\
\text { (LP2M) UIN Ar- } \\
\text { Raniry } \\
\end{array}$ & $\begin{array}{l}\text { Usulan Baru } \\
\text { mulai Volume } 1 \\
\text { Nomor } 2 \text { Tahun } \\
2018\end{array}$ \\
\hline & 27 & $\begin{array}{l}\text { Dentino: Jurnal } \\
\text { Kedokteran Gigi }\end{array}$ & 25274937 & $\begin{array}{l}\text { Fakultas } \\
\text { Kedokteran Gigi } \\
\text { Universitas } \\
\text { Lambung } \\
\text { Mangkurat }\end{array}$ & $\begin{array}{l}\text { Reakreditasi } \\
\text { Tetap di } \\
\text { Peringkat } 3 \text { mulai } \\
\text { Volume } 4 \text { Nomor } \\
2 \text { Tahun } 2019\end{array}$ \\
\hline & 28 & $\begin{array}{l}\text { Desimal: Jurnal } \\
\text { Matematika }\end{array}$ & 26139081 & $\begin{array}{l}\text { Prodi Pendidikan } \\
\text { Matamatika } \\
\text { Fakultas } \\
\text { Tarbiyah dan } \\
\text { Keguruan UIN } \\
\text { Raden Intan } \\
\text { Lampung }\end{array}$ & $\begin{array}{l}\text { Reakreditasi } \\
\text { Tetap di } \\
\text { Peringkat } 3 \text { mulai } \\
\text { Volume } 3 \text { Nomor } \\
1 \text { Tahun } 2020\end{array}$ \\
\hline & 29 & $\begin{array}{l}\text { Diglosia: Jurnal } \\
\text { Kajian Bahasa, } \\
\text { Sastra, dan } \\
\text { Pengajarannya }\end{array}$ & 26158655 & $\begin{array}{l}\text { Universitas } \\
\text { Mulawarman }\end{array}$ & $\begin{array}{l}\text { Reakreditasi Naik } \\
\text { Peringkat dari } \\
\text { Peringkat } 4 \text { ke } \\
\text { Peringkat } 3 \text { mulai } \\
\text { Volume } 3 \text { Nomor } \\
1 \text { Tahun } 2020\end{array}$ \\
\hline & 30 & $\begin{array}{l}\text { Dimas: Jurnal } \\
\text { Pemikiran Agama } \\
\text { untuk } \\
\text { Pemberdayaan }\end{array}$ & 25029428 & $\begin{array}{l}\text { LP2M UIN } \\
\text { Walisongo }\end{array}$ & $\begin{array}{l}\text { Reakreditasi Naik } \\
\text { Peringkat dari } \\
\text { Peringkat } 4 \text { ke } \\
\text { Peringkat } 3 \text { mulai } \\
\text { Volume } 19 \\
\text { Nomor } 2 \text { Tahun } \\
2019\end{array}$ \\
\hline & 31 & $\begin{array}{l}\text { Dinika Academic } \\
\text { Journal of Islamic } \\
\text { Studies }\end{array}$ & 25034227 & IAIN Surakarta & $\begin{array}{l}\text { Reakreditasi } \\
\text { Tetap di } \\
\text { Peringkat } 3 \text { mulai } \\
\text { Volume } 4 \text { Nomor } \\
3 \text { Tahun } 2019 \\
\end{array}$ \\
\hline & 32 & $\begin{array}{l}\text { Diponegoro } \\
\text { International } \\
\text { Journal of Business }\end{array}$ & 25804995 & $\begin{array}{l}\text { Universitas } \\
\text { Diponegoro }\end{array}$ & $\begin{array}{l}\text { Usulan Baru } \\
\text { mulai Volume } 1 \\
\text { Nomor } 1 \text { Tahun } \\
2018\end{array}$ \\
\hline
\end{tabular}

33. English ... 


\begin{tabular}{|c|c|c|c|c|c|}
\hline \begin{tabular}{|l|} 
Peringkat \\
\end{tabular} & No. & Nama Jurnal & E-ISSN & Penerbit & Keterangan \\
\hline & 33 & $\begin{array}{l}\text { English Franca: } \\
\text { Academic Journal of } \\
\text { English Language } \\
\text { and Education }\end{array}$ & 25803689 & $\begin{array}{l}\text { Institut Agama } \\
\text { Islam Negeri } \\
\text { (IAIN) Curup }\end{array}$ & $\begin{array}{l}\text { Reakreditasi } \\
\text { Tetap di } \\
\text { Peringkat } 3 \text { mulai } \\
\text { Volume } 3 \text { Nomor } \\
2 \text { Tahun } 2019\end{array}$ \\
\hline & 34 & $\begin{array}{l}\text { English Language } \\
\text { Teaching } \\
\text { Educational Journal }\end{array}$ & 26216485 & $\begin{array}{l}\text { Universitas } \\
\text { Ahmad Dahlan }\end{array}$ & $\begin{array}{l}\text { Usulan Baru } \\
\text { mulai Volume } 1 \\
\text { Nomor } 1 \text { Tahun } \\
2018\end{array}$ \\
\hline & 35 & $\begin{array}{l}\text { Fitofarmaka: Jurnal } \\
\text { Ilmiah Farmasi }\end{array}$ & $2622755 \mathrm{X}$ & $\begin{array}{l}\text { Universitas } \\
\text { Pakuan }\end{array}$ & $\begin{array}{l}\text { Usulan Baru } \\
\text { mulai Volume } 8 \\
\text { Nomor } 1 \text { Tahun } \\
2018\end{array}$ \\
\hline & 36 & $\begin{array}{l}\text { Food Science and } \\
\text { Technology Journal } \\
\text { (Foodscitech) }\end{array}$ & 26224127 & $\begin{array}{l}\text { Universitas Dr } \\
\text { Soetomo } \\
\text { Surabaya }\end{array}$ & $\begin{array}{l}\text { Usulan Baru } \\
\text { mulai Volume } 1 \\
\text { Nomor } 1 \text { Tahun } \\
2018\end{array}$ \\
\hline & 37 & $\begin{array}{l}\text { Gondang: Jurnal } \\
\text { Seni dan Budaya }\end{array}$ & 25990543 & $\begin{array}{l}\text { Universitas } \\
\text { Negeri Medan }\end{array}$ & $\begin{array}{l}\text { Reakreditasi Naik } \\
\text { Peringkat dari } \\
\text { Peringkat } 4 \text { ke } \\
\text { Peringkat } 3 \text { mulai } \\
\text { Volume } 3 \text { Nomor } \\
2 \text { Tahun } 2019\end{array}$ \\
\hline & 38 & $\begin{array}{l}\text { Harmoni Sosial: } \\
\text { Jurnal Pendidikan } \\
\text { IPS }\end{array}$ & 24607916 & $\begin{array}{l}\text { Himpunan } \\
\text { Sarjana } \\
\text { Pendidikan Ilmu- } \\
\text { Ilmu Sosial } \\
\text { Indonesia } \\
\text { (HISPISI) } \\
\text { bekerjasama } \\
\text { dengan Program } \\
\text { Studi Pendidikan } \\
\text { IPS Pascasarjana } \\
\text { Universitas } \\
\text { Negeri } \\
\text { Yogyakarta } \\
\end{array}$ & $\begin{array}{l}\text { Reakreditasi Naik } \\
\text { Peringkat dari } \\
\text { Peringkat } 4 \text { ke } \\
\text { Peringkat } 3 \text { mulai } \\
\text { Volume } 6 \text { Nomor } \\
2 \text { Tahun } 2019\end{array}$ \\
\hline & 39 & $\begin{array}{l}\text { Indonesian Journal } \\
\text { of Artificial } \\
\text { Intelligence and } \\
\text { Data Mining }\end{array}$ & 26146150 & $\begin{array}{l}\text { Universitas Islam } \\
\text { Negeri Sultan } \\
\text { Syarif Kasim } \\
\text { Riau }\end{array}$ & $\begin{array}{l}\text { Usulan Baru } \\
\text { mulai Volume } 1 \\
\text { Nomor } 1 \text { Tahun } \\
2018\end{array}$ \\
\hline & 40 & $\begin{array}{l}\text { Indonesian Journal } \\
\text { of Guidance and } \\
\text { Counseling: Theory } \\
\text { and Application }\end{array}$ & 25976133 & $\begin{array}{l}\text { Jurusan } \\
\text { Bimbingan dan } \\
\text { Konseling, } \\
\text { Fakultas Ilmu } \\
\text { Pendidikan, } \\
\text { Universitas } \\
\text { Negeri Semarang }\end{array}$ & $\begin{array}{l}\text { Reakreditasi } \\
\text { Tetap di } \\
\text { Peringkat } 3 \text { mulai } \\
\text { Volume } 8 \text { Nomor } \\
2 \text { Tahun } 2019\end{array}$ \\
\hline
\end{tabular}




\begin{tabular}{|c|c|c|c|c|c|}
\hline \begin{tabular}{|l|} 
Peringkat \\
\end{tabular} & No. & Nama Jurnal & E-ISSN & Penerbit & Keterangan \\
\hline & 41 & $\begin{array}{l}\text { Indonesian Journal } \\
\text { of Science and } \\
\text { Education }\end{array}$ & 25985205 & $\begin{array}{l}\text { Fakultas } \\
\text { Keguruan dan } \\
\text { Ilmu Pendidikan, } \\
\text { Universitas Tidar }\end{array}$ & $\begin{array}{l}\text { Reakreditasi } \\
\text { Tetap di } \\
\text { Peringkat } 3 \text { mulai } \\
\text { Volume } 3 \text { Nomor } \\
2 \text { Tahun } 2019 \\
\end{array}$ \\
\hline & 42 & $\begin{array}{l}\text { Indonesian Review } \\
\text { of Physics (IRiP) }\end{array}$ & 26212889 & $\begin{array}{l}\text { Universitas } \\
\text { Ahmad Dahlan }\end{array}$ & $\begin{array}{l}\text { Usulan Baru } \\
\text { mulai Volume } 1 \\
\text { Nomor } 1 \text { Tahun } \\
2018\end{array}$ \\
\hline & 43 & Infotekmesin & 26859858 & $\begin{array}{l}\text { P3M, Politeknik } \\
\text { Negeri Cilacap }\end{array}$ & $\begin{array}{l}\text { Reakreditasi Naik } \\
\text { Peringkat dari } \\
\text { Peringkat } 4 \text { ke } \\
\text { Peringkat } 3 \text { mulai } \\
\text { Volume } 11 \\
\text { Nomor } 1 \text { Tahun } \\
2020\end{array}$ \\
\hline & 44 & $\begin{array}{l}\text { International } \\
\text { Journal of Language } \\
\text { Teaching and } \\
\text { Education }\end{array}$ & 25982303 & $\begin{array}{l}\text { Magister Program } \\
\text { of English } \\
\text { Education } \\
\text { Department, } \\
\text { Universitas } \\
\text { Jambi }\end{array}$ & $\begin{array}{l}\text { Reakreditasi Naik } \\
\text { Peringkat dari } \\
\text { Peringkat } 4 \text { ke } \\
\text { Peringkat } 3 \text { mulai } \\
\text { Volume } 3 \text { Nomor } \\
2 \text { Tahun } 2019 \\
\end{array}$ \\
\hline & 45 & $\begin{array}{l}\text { International } \\
\text { Journal of Zakat } \\
\text { (IJAZ) }\end{array}$ & 25482335 & $\begin{array}{l}\text { Pusat Kajian } \\
\text { Strategis Badan } \\
\text { Amil Zakat } \\
\text { Nasional }\end{array}$ & $\begin{array}{l}\text { Usulan Baru } \\
\text { mulai Volume } 3 \\
\text { Nomor } 3 \text { Tahun } \\
2018\end{array}$ \\
\hline & 46 & $\begin{array}{l}\text { Istawa: Jurnal } \\
\text { Pendidikan Islam }\end{array}$ & 25410970 & $\begin{array}{l}\text { Postgraduate } \\
\text { Universitas } \\
\text { Muhammadiyah } \\
\text { Ponorogo }\end{array}$ & $\begin{array}{l}\text { Reakreditasi } \\
\text { Tetap di } \\
\text { Peringkat } 3 \text { mulai } \\
\text { Volume } 4 \text { Nomor } \\
2 \text { Tahun } 2019\end{array}$ \\
\hline & 47 & $\begin{array}{l}\text { JAK (Jurnal } \\
\text { Akuntansi): Kajian } \\
\text { Ilmiah Akuntansi }\end{array}$ & 25495968 & $\begin{array}{l}\text { Prodi Akuntansi } \\
\text { FEB Universitas } \\
\text { Serang Raya }\end{array}$ & $\begin{array}{l}\text { Reakreditasi Naik } \\
\text { Peringkat dari } \\
\text { Peringkat } 4 \text { ke } \\
\text { Peringkat } 3 \text { mulai } \\
\text { Volume } 7 \text { Nomor } \\
1 \text { Tahun } 2020\end{array}$ \\
\hline & 48 & $\begin{array}{l}\text { JAMP: Jurnal } \\
\text { Administrasi dan } \\
\text { Manajemen } \\
\text { Pendidikan }\end{array}$ & 26158574 & $\begin{array}{l}\text { Jurusan } \\
\text { Administrasi } \\
\text { Pendidikan } \\
\text { Fakultas Ilmu } \\
\text { Pendidikan } \\
\text { Universitas } \\
\text { Negeri Malang }\end{array}$ & $\begin{array}{l}\text { Usulan Baru } \\
\text { mulai Volume } 1 \\
\text { Nomor } 1 \text { Tahun } \\
2018\end{array}$ \\
\hline & 49 & $\begin{array}{l}\text { Jati: Jurnal } \\
\text { Akuntansi Terapan } \\
\text { Indonesia }\end{array}$ & 26150689 & $\begin{array}{l}\text { Universitas } \\
\text { Muhammadiyah } \\
\text { Yogyakarta }\end{array}$ & $\begin{array}{l}\text { Usulan Baru } \\
\text { mulai Volume } 1 \\
\text { Nomor } 1 \text { Tahun } \\
2018\end{array}$ \\
\hline
\end{tabular}




\begin{tabular}{|c|c|c|c|c|c|}
\hline \begin{tabular}{|l|} 
Peringkat \\
\end{tabular} & No. & Nama Jurnal & E-ISSN & Penerbit & Keterangan \\
\hline & 50 & $\begin{array}{l}\text { JIPI (Jurnal IPA dan } \\
\text { Pembelajaran IPA) }\end{array}$ & $2620553 X$ & $\begin{array}{l}\text { Universitas Syiah } \\
\text { Kuala }\end{array}$ & $\begin{array}{l}\text { Reakreditasi } \\
\text { Tetap di } \\
\text { Peringkat } 3 \text { mulai } \\
\text { Volume } 3 \text { Nomor } \\
2 \text { Tahun } 2019\end{array}$ \\
\hline & 51 & $\begin{array}{l}\text { JITeCS (Journal of } \\
\text { Information } \\
\text { Technology and } \\
\text { Computer Science) }\end{array}$ & 25409824 & $\begin{array}{l}\text { Fakultas Ilmu } \\
\text { Komputer, } \\
\text { Universitas } \\
\text { Brawijaya }\end{array}$ & $\begin{array}{l}\text { Reakreditasi Naik } \\
\text { Peringkat dari } \\
\text { Peringkat } 4 \text { ke } \\
\text { Peringkat } 3 \text { mulai } \\
\text { Volume } 4 \text { Nomor } \\
\text { 3 Tahun } 2019\end{array}$ \\
\hline & 52 & $\begin{array}{l}\text { JMIE (Journal of } \\
\text { Madrasah } \\
\text { Ibtidaiyah } \\
\text { Education) }\end{array}$ & 25802739 & $\begin{array}{l}\text { Perkumpulan } \\
\text { Dosen } \\
\text { Pendidikan Guru } \\
\text { Madrasah } \\
\text { Ibtidaiyah } \\
\text { se-Indonesia }\end{array}$ & $\begin{array}{l}\text { Reakreditasi Naik } \\
\text { Peringkat dari } \\
\text { Peringkat } 4 \text { ke } \\
\text { Peringkat } 3 \text { mulai } \\
\text { Volume } 3 \text { Nomor } \\
2 \text { Tahun } 2019\end{array}$ \\
\hline & 53 & $\begin{array}{l}\text { JMM (Jurnal } \\
\text { Masyarakat } \\
\text { Mandiri) }\end{array}$ & 26145758 & $\begin{array}{l}\text { Universitas } \\
\text { Muhammadiyah } \\
\text { Mataram }\end{array}$ & $\begin{array}{l}\text { Reakreditasi Naik } \\
\text { Peringkat dari } \\
\text { Peringkat } 4 \text { ke } \\
\text { Peringkat } 3 \text { mulai } \\
\text { Volume } 4 \text { Nomor } \\
1 \text { Tahun } 2020 \\
\end{array}$ \\
\hline & 54 & $\begin{array}{l}\text { JOMIS (Journal of } \\
\text { Midwifery Science) }\end{array}$ & 25797077 & $\begin{array}{l}\text { LPPM Universitas } \\
\text { Abdurrab }\end{array}$ & $\begin{array}{l}\text { Usulan Baru } \\
\text { mulai Volume } 3 \\
\text { Nomor } 1 \text { Tahun } \\
2019\end{array}$ \\
\hline & 55 & $\begin{array}{l}\text { Journal } \\
\text { Communication } \\
\text { Spectrum: Capturing } \\
\text { New Perspectives in } \\
\text { Communication } \\
\end{array}$ & 26226405 & $\begin{array}{l}\text { UB Press } \\
\text { Universitas } \\
\text { Bakrie }\end{array}$ & $\begin{array}{l}\text { Usulan Baru } \\
\text { mulai Volume } 8 \\
\text { Nomor } 1 \text { Tahun } \\
2018\end{array}$ \\
\hline & 56 & $\begin{array}{l}\text { Journal of } \\
\text { Indonesian Dental } \\
\text { Association }\end{array}$ & 26216175 & $\begin{array}{l}\text { Persatuan Dokter } \\
\text { Gigi Indonesia }\end{array}$ & $\begin{array}{l}\text { Usulan Baru } \\
\text { mulai Volume } 1 \\
\text { Nomor } 1 \text { Tahun } \\
2018\end{array}$ \\
\hline & 57 & $\begin{array}{l}\text { Journal of Applied } \\
\text { Food Technology }\end{array}$ & 26147076 & $\begin{array}{l}\text { Fakultas } \\
\text { Peternakan dan } \\
\text { Pertanian } \\
\text { Universitas } \\
\text { Diponegoro } \\
\text { bekerjasama } \\
\text { dengan } \\
\text { Indonesian Food } \\
\text { Technologists } \\
\end{array}$ & $\begin{array}{l}\text { Usulan Baru } \\
\text { mulai Volume } 5 \\
\text { Nomor } 1 \text { Tahun } \\
2018\end{array}$ \\
\hline & 58 & $\begin{array}{l}\text { Journal of } \\
\text { Community } \\
\text { Empowerment for } \\
\text { Health }\end{array}$ & 26550164 & $\begin{array}{l}\text { Universitas } \\
\text { Gadjah Mada }\end{array}$ & $\begin{array}{l}\text { Usulan Baru } \\
\text { mulai Volume } 1 \\
\text { Nomor } 1 \text { Tahun } \\
2018\end{array}$ \\
\hline
\end{tabular}




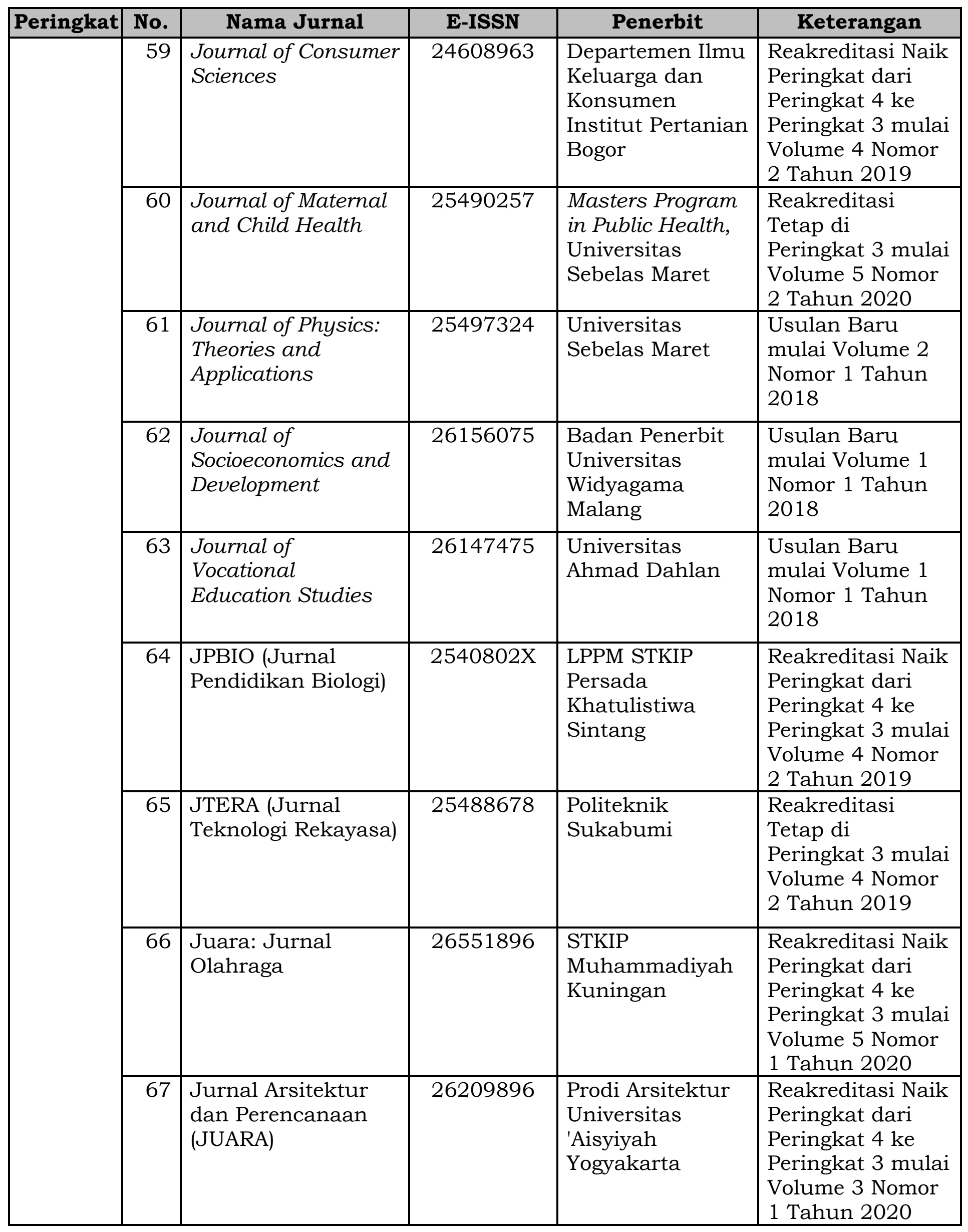

68. Jurnal ... 


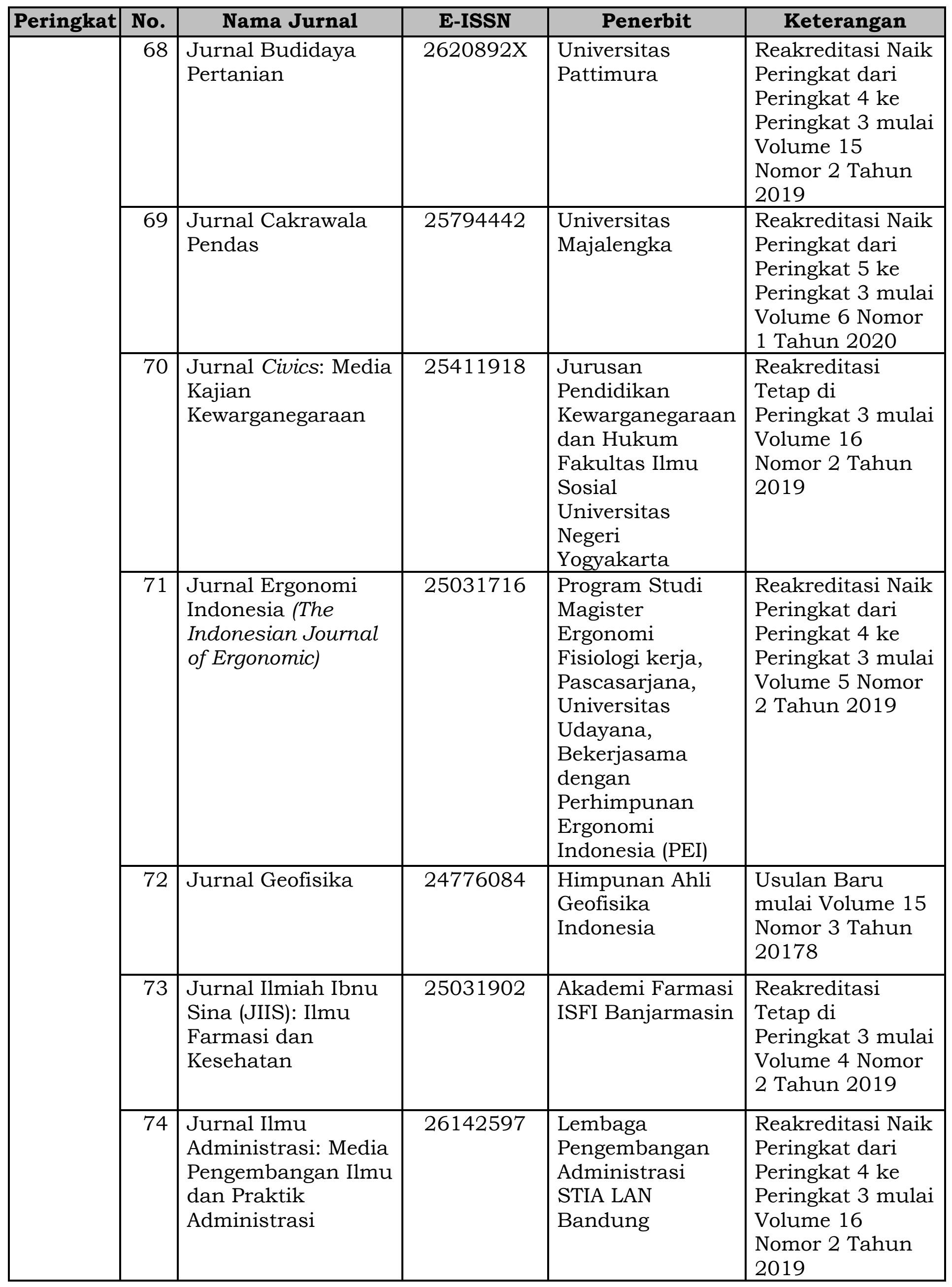




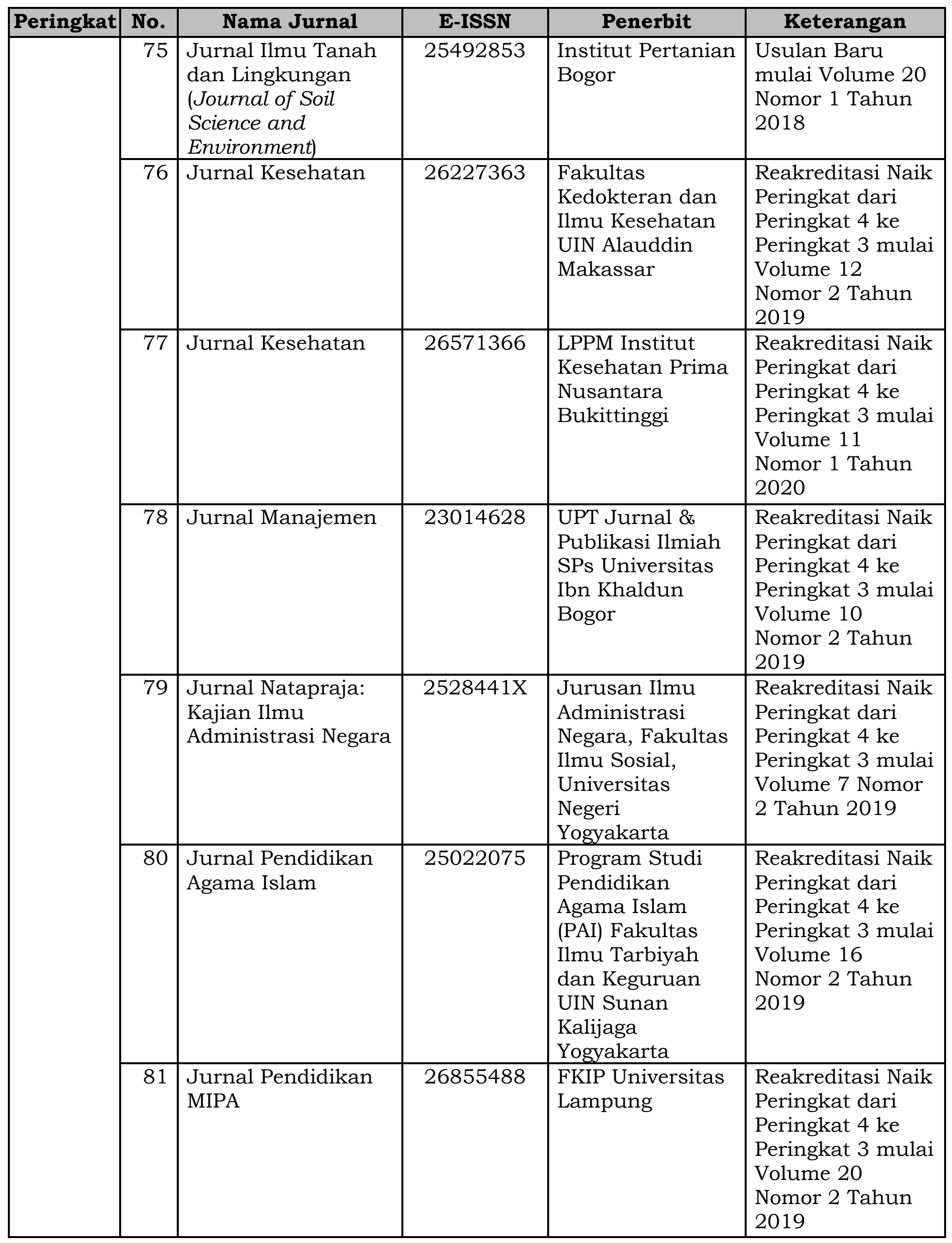

82. Jurnal ... 


\begin{tabular}{|c|c|c|c|c|c|}
\hline Peringkat & No. & Nama Jurnal & E-ISSN & Penerbit & Keterangan \\
\hline & 82 & $\begin{array}{l}\text { Jurnal Penelitan } \\
\text { Ekonomi dan Bisnis }\end{array}$ & 2460429 & $\begin{array}{l}\text { Fakultas } \\
\text { Ekonomi dan } \\
\text { Bisnis, } \\
\text { Universitas Dian } \\
\text { Nuswantoro }\end{array}$ & $\begin{array}{l}\text { Reakreditasi Naik } \\
\text { Peringkat dari } \\
\text { Peringkat } 4 \text { ke } \\
\text { Peringkat } 3 \\
\text { mulai Volume } 4 \\
\text { Nomor } 2 \text { Tahun } \\
2019\end{array}$ \\
\hline & 83 & $\begin{array}{l}\text { Jurnal Penelitian } \\
\text { Ilmu Pendidikan }\end{array}$ & 25415492 & $\begin{array}{l}\text { Fakultas Ilmu } \\
\text { Pendidikan } \\
\text { Universitas } \\
\text { Negeri } \\
\text { Yogyakarta }\end{array}$ & $\begin{array}{l}\text { Reakreditasi Naik } \\
\text { Peringkat dari } \\
\text { Peringkat } 4 \text { ke } \\
\text { Peringkat } 3 \\
\text { mulai Volume } 12 \\
\text { Nomor } 2 \text { Tahun } \\
2019 \\
\end{array}$ \\
\hline & 84 & Jurnal Promkes & 25409972 & $\begin{array}{l}\text { Fakultas } \\
\text { Kesehatan } \\
\text { Masyarakat } \\
\text { Universitas } \\
\text { Airlangga }\end{array}$ & $\begin{array}{l}\text { Reakreditasi Naik } \\
\text { Peringkat dari } \\
\text { Peringkat } 4 \text { ke } \\
\text { Peringkat } 3 \text { mulai } \\
\text { Volume } 7 \text { Nomor } \\
2 \text { Tahun } 2019\end{array}$ \\
\hline & 85 & $\begin{array}{l}\text { Jurnal } \\
\text { Psikohumanika }\end{array}$ & 23020660 & $\begin{array}{l}\text { Fakultas } \\
\text { Psikologi } \\
\text { Universitas Setia } \\
\text { Budi Surakarta }\end{array}$ & $\begin{array}{l}\text { Usulan Baru } \\
\text { mulai Volume } 10 \\
\text { Nomor } 1 \text { Tahun } \\
2018\end{array}$ \\
\hline & 86 & $\begin{array}{l}\text { Jurnal Psikologi } \\
\text { Pendidikan dan } \\
\text { Konseling: Jurnal } \\
\text { Kajian Psikologi } \\
\text { Pendidikan dan } \\
\text { Bimbingan } \\
\text { Konseling } \\
\end{array}$ & 24772518 & $\begin{array}{l}\text { Universitas } \\
\text { Negeri Makassar }\end{array}$ & $\begin{array}{l}\text { Reakreditasi } \\
\text { Tetap di } \\
\text { Peringkat } 3 \text { mulai } \\
\text { Volume } 5 \text { Nomor } \\
2 \text { Tahun } 2019\end{array}$ \\
\hline & 87 & $\begin{array}{l}\text { Jurnal Rekayasa } \\
\text { Sistem Industri }\end{array}$ & 23391499 & $\begin{array}{l}\text { Teknik Industri - } \\
\text { Universitas } \\
\text { Katolik } \\
\text { Parahyangan }\end{array}$ & $\begin{array}{l}\text { Reakreditasi Naik } \\
\text { Peringkat dari } \\
\text { Peringkat } 4 \text { ke } \\
\text { Peringkat } 3 \text { mulai } \\
\text { Volume } 8 \text { Nomor } \\
2 \text { Tahun } 2019\end{array}$ \\
\hline & 88 & $\begin{array}{l}\text { Jurnal Sistem dan } \\
\text { Manajemen Industri }\end{array}$ & 25802895 & $\begin{array}{l}\text { Universitas } \\
\text { Serang Raya }\end{array}$ & $\begin{array}{l}\text { Reakreditasi } \\
\text { Tetap di } \\
\text { Peringkat } 3 \text { mulai } \\
\text { Volume } 3 \text { Nomor } \\
2 \text { Tahun } 2019\end{array}$ \\
\hline & 89 & $\begin{array}{l}\text { Jurnal Tadris } \\
\text { Matematika }\end{array}$ & 26214008 & $\begin{array}{l}\text { Jurusan Tadris } \\
\text { Matematika, IAIN } \\
\text { Tulungagung }\end{array}$ & $\begin{array}{l}\text { Usulan Baru } \\
\text { mulai Volume } 1 \\
\text { Nomor } 1 \text { Tahun } \\
2018\end{array}$ \\
\hline & 90 & $\begin{array}{l}\text { Jurnal Tekno } \\
\text { Insentif }\end{array}$ & $2655089 X$ & $\begin{array}{l}\text { Lembaga } \\
\text { Layanan } \\
\text { Pendidikan } \\
\text { Tinggi Wilayah IV }\end{array}$ & $\begin{array}{l}\text { Usulan Baru } \\
\text { mulai Volume } 12 \\
\text { Nomor } 2 \text { Tahun } \\
2018\end{array}$ \\
\hline
\end{tabular}




\begin{tabular}{|c|c|c|c|c|c|}
\hline Peringkat & No. & Nama Jurnal & E-ISSN & Penerbit & Keterangan \\
\hline & 91 & $\begin{array}{l}\text { Jurnal Universitas } \\
\text { Kadiri Riset Teknik } \\
\text { Sipil }\end{array}$ & 25810855 & $\begin{array}{l}\text { Universitas } \\
\text { Kadiri }\end{array}$ & $\begin{array}{l}\text { Usulan Baru } \\
\text { mulai Volume } 2 \\
\text { Nomor } 1 \text { Tahun } \\
2018\end{array}$ \\
\hline & 92 & Komunikator & 25499246 & $\begin{array}{l}\text { Jurusan Ilmu } \\
\text { Komunikasi } \\
\text { Universitas } \\
\text { Muhammadiyah } \\
\text { Yogyakarta }\end{array}$ & $\begin{array}{l}\text { Reakreditasi } \\
\text { Tetap di } \\
\text { Peringkat } 3 \text { mulai } \\
\text { Volume } 11 \\
\text { Nomor } 2 \text { Tahun } \\
2019\end{array}$ \\
\hline & 93 & $\begin{array}{l}\text { Kontemplasi: Jurnal } \\
\text { Ke-Ushuluddinan }\end{array}$ & 25806866 & $\begin{array}{l}\text { Institut Agama } \\
\text { Islam Negeri } \\
\text { Tulungagung }\end{array}$ & $\begin{array}{l}\text { Usulan Baru } \\
\text { mulai Volume } 6 \\
\text { Nomor } 1 \text { Tahun } \\
2018\end{array}$ \\
\hline & 94 & Konversi & 25413481 & $\begin{array}{l}\text { Program Studi } \\
\text { Teknik Kimia } \\
\text { Fakultas Teknik } \\
\text { Universitas } \\
\text { Lambung } \\
\text { Mangkurat }\end{array}$ & $\begin{array}{l}\text { Reakreditasi Naik } \\
\text { Peringkat dari } \\
\text { Peringkat } 4 \text { ke } \\
\text { Peringkat } 3 \text { mulai } \\
\text { Volume } 8 \text { Nomor } \\
2 \text { Tahun } 2019\end{array}$ \\
\hline & 95 & $\begin{array}{l}\text { Lensa: Kajian } \\
\text { Kebahasaan, } \\
\text { Kesusastraan, dan } \\
\text { Budaya }\end{array}$ & $2503328 \mathrm{X}$ & $\begin{array}{l}\text { Fakultas Bahasa } \\
\text { dan Budaya } \\
\text { Asing (FBBA), } \\
\text { Universitas } \\
\text { Muhammadiyah } \\
\text { Semarang }\end{array}$ & $\begin{array}{l}\text { Reakreditasi } \\
\text { Tetap di } \\
\text { Peringkat } 3 \text { mulai } \\
\text { Volume } 9 \text { Nomor } \\
2 \text { Tahun } 2019\end{array}$ \\
\hline & 96 & Lentera Hukum & 26213710 & $\begin{array}{l}\text { Universitas } \\
\text { Jember }\end{array}$ & $\begin{array}{l}\text { Reakreditasi } \\
\text { Tetap di } \\
\text { Peringkat } 3 \text { mulai } \\
\text { Volume } 6 \text { Nomor } \\
3 \text { Tahun } 2019\end{array}$ \\
\hline & 97 & $\begin{array}{l}\text { Lentera Pustaka: } \\
\text { Jurnal Kajian Ilmu } \\
\text { Perpustakaan, } \\
\text { Informasi dan } \\
\text { Kearsipan }\end{array}$ & 25409638 & $\begin{array}{l}\text { Program Studi } \\
\text { Ilmu } \\
\text { Perpustakaan } \\
\text { Fakultas Ilmu } \\
\text { Budaya } \\
\text { Universitas } \\
\text { Diponegoro }\end{array}$ & $\begin{array}{l}\text { Reakreditasi } \\
\text { Tetap di } \\
\text { Peringkat } 3 \text { mulai } \\
\text { Volume } 5 \text { Nomor } \\
2 \text { Tahun } 2019\end{array}$ \\
\hline & 98 & $\begin{array}{l}\text { LINGUA: Jurnal } \\
\text { Bahasa, Sastra, dan } \\
\text { Pengajarannya }\end{array}$ & $2442238 X$ & $\begin{array}{l}\text { Center of } \\
\text { Language and } \\
\text { Cultural Studies }\end{array}$ & $\begin{array}{l}\text { Reakreditasi } \\
\text { Tetap di } \\
\text { Peringkat } 3 \text { mulai } \\
\text { Volume } 15 \\
\text { Nomor } 2 \text { Tahun } \\
2018\end{array}$ \\
\hline & 99 & $\begin{array}{l}\text { Media Keperawatan } \\
\text { Indonesia }\end{array}$ & 26151669 & $\begin{array}{l}\text { LPPM Universitas } \\
\text { Muhammadiyah } \\
\text { Semarang }\end{array}$ & $\begin{array}{l}\text { Reakreditasi Naik } \\
\text { Peringkat dari } \\
\text { Peringkat } 4 \text { ke } \\
\text { Peringkat } 3 \text { mulai }\end{array}$ \\
\hline
\end{tabular}




\begin{tabular}{|c|c|c|c|c|c|}
\hline Peringkat & No. & Nama Jurnal & E-ISSN & Penerbit & Keterangan \\
\hline & & & & & $\begin{array}{l}\text { Volume } 3 \text { Nomor } \\
1 \text { Tahun } 2020\end{array}$ \\
\hline & 100 & $\begin{array}{l}\text { Metathesis: Journal } \\
\text { of English } \\
\text { Language, Literature } \\
\text { and Teaching }\end{array}$ & 25802720 & $\begin{array}{l}\text { Fakultas } \\
\text { Keguruan dan } \\
\text { Ilmu Pendidikan } \\
\text { Universitas Tidar }\end{array}$ & $\begin{array}{l}\text { Reakreditasi Naik } \\
\text { Peringkat dari } \\
\text { Peringkat } 4 \text { ke } \\
\text { Peringkat } 3 \text { mulai } \\
\text { Volume } 3 \text { Nomor } \\
2 \text { Tahun } 2019\end{array}$ \\
\hline & 101 & Muslim Heritage & 25025341 & $\begin{array}{l}\text { Institusi Agama } \\
\text { Islam Negeri } \\
\text { Ponorogo }\end{array}$ & $\begin{array}{l}\text { Reakreditasi Naik } \\
\text { Peringkat dari } \\
\text { Peringkat } 4 \text { ke } \\
\text { Peringkat } 3 \text { mulai } \\
\text { Volume } 4 \text { Nomor } \\
2 \text { Tahun } 2019\end{array}$ \\
\hline & 102 & $\begin{array}{l}\text { Nazhruna: Jurnal } \\
\text { Pendidikan Islam }\end{array}$ & 26148013 & $\begin{array}{l}\text { Program Studi } \\
\text { Pendidikan Islam } \\
\text { Institut } \\
\text { Pesantren KH } \\
\text { Abdul Chalim } \\
\text { Pacet Mojokerto }\end{array}$ & $\begin{array}{l}\text { Reakreditasi } \\
\text { Tetap di } \\
\text { Peringkat } 3 \text { mulai } \\
\text { Volume } 4 \text { Nomor } \\
1 \text { Tahun } 2020\end{array}$ \\
\hline & 103 & $\begin{array}{l}\text { NOBEL: Journal of } \\
\text { Literature and } \\
\text { Language Teaching }\end{array}$ & 25492470 & $\begin{array}{l}\text { English } \\
\text { Department, } \\
\text { Faculty of Arts } \\
\text { and Humanities, } \\
\text { UIN Sunan } \\
\text { Ampel Surabaya }\end{array}$ & $\begin{array}{l}\text { Reakreditasi } \\
\text { Tetap di } \\
\text { Peringkat } 3 \text { mulai } \\
\text { Volume } 10 \\
\text { Nomor } 2 \text { Tahun } \\
2019\end{array}$ \\
\hline & 104 & $\begin{array}{l}\text { Nurse and Health: } \\
\text { Jurnal Keperawatan }\end{array}$ & 26232448 & $\begin{array}{l}\text { LPPM Akademi } \\
\text { Keperawatan } \\
\text { Kerta Cendekia } \\
\text { Sidoarjo }\end{array}$ & $\begin{array}{l}\text { Reakreditasi Naik } \\
\text { Peringkat dari } \\
\text { Peringkat } 4 \text { ke } \\
\text { Peringkat } 3 \text { mulai } \\
\text { Volume } 8 \text { Nomor } \\
2 \text { Tahun } 2019\end{array}$ \\
\hline & 105 & $\begin{array}{l}\text { Organum: Jurnal } \\
\text { Saintifik } \\
\text { Manajemen dan } \\
\text { Akuntansi }\end{array}$ & 26208164 & $\begin{array}{l}\text { Universitas } \\
\text { Winaya Mukti }\end{array}$ & $\begin{array}{l}\text { Usulan Baru } \\
\text { mulai Volume } 1 \\
\text { Nomor } 1 \text { Tahun } \\
2018\end{array}$ \\
\hline & 106 & PCD Journal & 20850441 & $\begin{array}{l}\text { Research Center } \\
\text { for Politics and } \\
\text { Government } \\
\text { (PolGov) } \\
\text { Universitas } \\
\text { Gadjah Mada }\end{array}$ & $\begin{array}{l}\text { Reakreditasi } \\
\text { Tetap di } \\
\text { Peringkat } 3 \text { mulai } \\
\text { Volume } 7 \text { Nomor } \\
2 \text { Tahun } 2019\end{array}$ \\
\hline
\end{tabular}




\begin{tabular}{|c|c|c|c|c|c|}
\hline \begin{tabular}{|l|} 
Peringkat \\
\end{tabular} & No. & Nama Jurnal & E-ISSN & Penerbit & Keterangan \\
\hline & 107 & Perspektif & 26849305 & $\begin{array}{l}\text { Universitas } \\
\text { Medan Area }\end{array}$ & $\begin{array}{l}\text { Reakreditasi Naik } \\
\text { Peringkat dari } \\
\text { Peringkat } 4 \text { ke } \\
\text { Peringkat } 3 \text { mulai } \\
\text { Volume } 9 \text { Nomor } \\
1 \text { Tahun } 2020\end{array}$ \\
\hline & 108 & $\begin{array}{l}\text { Pilar Nusa Mandiri: } \\
\text { Journal of } \\
\text { Computing and } \\
\text { Information System }\end{array}$ & 25276514 & $\begin{array}{l}\text { LPPM STMIK } \\
\text { Nusa Mandiri } \\
\text { Jakarta }\end{array}$ & $\begin{array}{l}\text { Reakreditasi } \\
\text { Tetap di } \\
\text { Peringkat } 3 \text { mulai } \\
\text { Volume } 15 \\
\text { Nomor } 2 \text { Tahun } \\
2019\end{array}$ \\
\hline & 109 & $\begin{array}{l}\text { Prima: Jurnal } \\
\text { Pendidikan } \\
\text { Matematika }\end{array}$ & 25802216 & $\begin{array}{l}\text { FKIP Universitas } \\
\text { Muhammadiyah } \\
\text { Tangerang }\end{array}$ & $\begin{array}{l}\text { Reakreditasi Naik } \\
\text { Peringkat dari } \\
\text { Peringkat } 4 \text { ke } \\
\text { Peringkat } 3 \text { mulai } \\
\text { Volume } 4 \text { Nomor } \\
1 \text { Tahun } 2020\end{array}$ \\
\hline & 110 & $\begin{array}{l}\text { Prisma Sains: } \\
\text { Jurnal Pengkajian } \\
\text { Ilmu dan } \\
\text { Pembelajaran } \\
\text { Matematika dan IPA } \\
\text { IKIP Mataram }\end{array}$ & 25407899 & $\begin{array}{l}\text { Fakultas } \\
\text { Pendidikan } \\
\text { Matematika dan } \\
\text { IPA IKIP Mataram }\end{array}$ & $\begin{array}{l}\text { Reakreditasi } \\
\text { Tetap di } \\
\text { Peringkat } 3 \text { mulai } \\
\text { Volume } 7 \text { Nomor } \\
2 \text { Tahun } 2019\end{array}$ \\
\hline & 111 & Refleksi & 27146103 & $\begin{array}{l}\text { Fakultas } \\
\text { Ushuluddin UIN } \\
\text { Syarif } \\
\text { Hidayatullah } \\
\text { Jakarta }\end{array}$ & $\begin{array}{l}\text { Usulan Baru } \\
\text { mulai Volume } 17 \\
\text { Nomor } 1 \text { Tahun } \\
2018\end{array}$ \\
\hline & 112 & $\begin{array}{l}\text { Research: Computer, } \\
\text { Information System } \\
\& \text { Technology } \\
\text { Management }\end{array}$ & 26157357 & $\begin{array}{l}\text { Universitas PGRI } \\
\text { Madiun }\end{array}$ & $\begin{array}{l}\text { Usulan Baru } \\
\text { mulai Volume } 1 \\
\text { Nomor } 1 \text { Tahun } \\
2018\end{array}$ \\
\hline & 113 & $\begin{array}{l}\text { Riwayah: Jurnal } \\
\text { Studi Hadis }\end{array}$ & 25028839 & $\begin{array}{l}\text { Program Studi } \\
\text { Ilmu Hadis, } \\
\text { Jurusan } \\
\text { Ushuluddin } \\
\text { Sekolah Tinggi } \\
\text { Agama Islam } \\
\text { Negeri Kudus }\end{array}$ & $\begin{array}{l}\text { Reakreditasi Naik } \\
\text { Peringkat dari } \\
\text { Peringkat } 5 \text { ke } \\
\text { Peringkat } 3 \text { mulai } \\
\text { Volume } 5 \text { Nomor } \\
2 \text { Tahun } 2019\end{array}$ \\
\hline & 114 & $\begin{array}{l}\text { Science and } \\
\text { Technology } \\
\text { Indonesia }\end{array}$ & 25804391 & $\begin{array}{l}\text { Jurusan Kimia } \\
\text { FMIPA } \\
\text { Universitas } \\
\text { Sriwijaya }\end{array}$ & $\begin{array}{l}\text { Reakreditasi } \\
\text { Tetap di } \\
\text { Peringkat } 3 \text { mulai } \\
\text { Volume } 5 \text { Nomor } \\
1 \text { Tahun } 2020\end{array}$ \\
\hline
\end{tabular}




\begin{tabular}{|c|c|c|c|c|c|}
\hline \multirow[t]{9}{*}{ Peringkat } & No. & Nama Jurnal & E-ISSN & Penerbit & Keterangan \\
\hline & 115 & $\begin{array}{l}\text { Scientiae Educatia: } \\
\text { Jurnal Pendidikan } \\
\text { Sains }\end{array}$ & 25277596 & $\begin{array}{l}\text { Tadris Biologi } \\
\text { IAIN Syekh } \\
\text { Nurjati Cirebon } \\
\text { bekerjasama } \\
\text { dengan PPII } \\
\text { (Perhimpunan } \\
\text { Pendidik IPA } \\
\text { Indonesia) }\end{array}$ & $\begin{array}{l}\text { Reakreditasi } \\
\text { Tetap di } \\
\text { Peringkat } 3 \text { mulai } \\
\text { Volume } 8 \text { Nomor } \\
2 \text { Tahun } 2019\end{array}$ \\
\hline & 116 & Simulacra & 26568721 & $\begin{array}{l}\text { Universitas } \\
\text { Trunojoyo } \\
\text { Madura }\end{array}$ & $\begin{array}{l}\text { Usulan Baru } \\
\text { mulai Volume } 1 \\
\text { Nomor } 1 \text { Tahun } \\
2018\end{array}$ \\
\hline & 117 & $\begin{array}{l}\text { Sosioglobal: Jurnal } \\
\text { Pemikiran dan } \\
\text { Penelitian Sosiologi }\end{array}$ & 25484559 & $\begin{array}{l}\text { Departemen } \\
\text { Sosiologi, } \\
\text { Fakultas Ilmu } \\
\text { Sosial dan Ilmu } \\
\text { Politik, } \\
\text { Universitas } \\
\text { Padjadjaran } \\
\end{array}$ & $\begin{array}{l}\text { Reakreditasi Naik } \\
\text { Peringkat dari } \\
\text { Peringkat } 6 \text { ke } \\
\text { Peringkat } 3 \text { mulai } \\
\text { Volume } 4 \text { Nomor } \\
1 \text { Tahun } 2019\end{array}$ \\
\hline & 118 & $\begin{array}{l}\text { Tadbir: Jurnal Studi } \\
\text { Manajemen } \\
\text { Pendidikan }\end{array}$ & 25805037 & $\begin{array}{l}\text { Institut Agama } \\
\text { Islam Negeri } \\
\text { (IAIN) Curup }\end{array}$ & $\begin{array}{l}\text { Reakreditasi } \\
\text { Tetap di } \\
\text { Peringkat } 3 \text { mulai } \\
\text { Volume } 3 \text { Nomor } \\
2 \text { Tahun } 2019\end{array}$ \\
\hline & 119 & $\begin{array}{l}\text { Ta'dib: Jurnal } \\
\text { Pendidikan Islam }\end{array}$ & 25285092 & $\begin{array}{l}\text { Fakultas } \\
\text { Tarbiyah dan } \\
\text { Keguruan } \\
\text { Universitas Islam } \\
\text { Bandung dan } \\
\text { Asosiasi Dosen } \\
\text { Pendidikan } \\
\text { Agama Islam } \\
\text { Indonesia } \\
\text { (ADPISI) }\end{array}$ & $\begin{array}{l}\text { Usulan Baru } \\
\text { mulai Volume } 7 \\
\text { Nomor } 1 \text { Tahun } \\
2018\end{array}$ \\
\hline & 120 & $\begin{array}{l}\text { The Indonesian } \\
\text { Journal of } \\
\text { Occupational Safety } \\
\text { and Health }\end{array}$ & 25407872 & $\begin{array}{l}\text { Fakultas } \\
\text { Kesehatan } \\
\text { Masyarakat } \\
\text { Universitas } \\
\text { Airlangga }\end{array}$ & $\begin{array}{l}\text { Reakreditasi Naik } \\
\text { Peringkat dari } \\
\text { Peringkat } 4 \text { ke } \\
\text { Peringkat } 3 \text { mulai } \\
\text { Volume } 8 \text { Nomor } \\
\text { 3 Tahun } 2019 \\
\end{array}$ \\
\hline & 121 & $\begin{array}{l}\text { Veritas: Jurnal } \\
\text { Teologi dan } \\
\text { Pelayanan }\end{array}$ & 26849194 & $\begin{array}{l}\text { Sekolah Tinggi } \\
\text { Teologi SAAT }\end{array}$ & $\begin{array}{l}\text { Reakreditasi } \\
\text { Tetap di } \\
\text { Peringkat } 3 \text { mulai } \\
\text { Volume } 18 \\
\text { Nomor } 2 \text { Tahun } \\
2019\end{array}$ \\
\hline & 122 & $\begin{array}{l}\text { Volksgeist: Jurnal } \\
\text { Ilmu Hukum dan } \\
\text { Konstitusi }\end{array}$ & 26155648 & $\begin{array}{l}\text { Fakultas Syariah } \\
\text { IAIN Purwokerto }\end{array}$ & $\begin{array}{l}\text { Usulan Baru } \\
\text { mulai Volume } 1 \\
\text { Nomor } 1 \text { Tahun } \\
2018\end{array}$ \\
\hline
\end{tabular}




\begin{tabular}{|c|c|c|c|c|c|}
\hline Peringkat & No. & Nama Jurnal & E-ISSN & Penerbit & Keterangan \\
\hline & 123 & Warta LPM & 25495631 & $\begin{array}{l}\text { Lembaga } \\
\text { Penelitian dan } \\
\text { Pengabdian } \\
\text { Masyarakat } \\
\text { Universitas } \\
\text { Muhammadiyah } \\
\text { Surakarta } \\
\end{array}$ & $\begin{array}{l}\text { Reakreditasi Naik } \\
\text { Peringkat dari } \\
\text { Peringkat } 5 \text { ke } \\
\text { Peringkat } 3 \text { mulai } \\
\text { Volume } 23 \\
\text { Nomor } 1 \text { Tahun } \\
2020\end{array}$ \\
\hline \multirow[t]{8}{*}{4} & 1 & Abdimas Dewantara & 26158782 & $\begin{array}{l}\text { Universitas } \\
\text { sarjanawiyata } \\
\text { Tamansiswa }\end{array}$ & $\begin{array}{l}\text { Usulan Baru } \\
\text { mulai Volume } 1 \\
\text { Nomor } 1 \text { Tahun } \\
2018\end{array}$ \\
\hline & 2 & $\begin{array}{l}\text { Administratio: } \\
\text { Jurnal Ilmiah } \\
\text { Administrasi Publik } \\
\text { dan Pembangunan }\end{array}$ & 25486977 & $\begin{array}{l}\text { Jurusan Ilmu } \\
\text { Administrasi } \\
\text { Publik Fakultas } \\
\text { Ilmu Sosial dan } \\
\text { Ilmu Politik } \\
\text { Universitas } \\
\text { Lampung dan } \\
\text { Perhimpunan } \\
\text { Sarjana } \\
\text { Administrasi } \\
\text { Indonesia }\end{array}$ & $\begin{array}{l}\text { Reakreditasi Naik } \\
\text { Peringkat dari } \\
\text { Peringkat } 6 \mathrm{ke} \\
\text { Peringkat } 4 \text { mulai } \\
\text { Volume } 9 \text { Nomor } \\
1 \text { Tahun } 2018\end{array}$ \\
\hline & 3 & $\begin{array}{l}\text { Agrosains: Jurnal } \\
\text { Penelitian Agronomi }\end{array}$ & 26557339 & $\begin{array}{l}\text { Universitas } \\
\text { Sebelas Maret }\end{array}$ & $\begin{array}{l}\text { Usulan Baru } \\
\text { mulai Volume } 20 \\
\text { Nomor } 1 \text { Tahun } \\
2018\end{array}$ \\
\hline & 4 & $\begin{array}{l}\text { Al Fikra: Jurnal } \\
\text { Ilmiah Keislaman }\end{array}$ & 25027263 & $\begin{array}{l}\text { Universitas Islam } \\
\text { Negri Sultan } \\
\text { Syarif Kasim } \\
\text { Riau }\end{array}$ & $\begin{array}{l}\text { Usulan Baru } \\
\text { mulai Volume } 17 \\
\text { Nomor } 1 \text { Tahun } \\
2018\end{array}$ \\
\hline & 5 & $\begin{array}{l}\text { Al-Adabiya: Jurnal } \\
\text { Kebudayaan dan } \\
\text { Keagamaan }\end{array}$ & 25409204 & $\begin{array}{l}\text { IAI Sunan Giri } \\
\text { Ponorogo }\end{array}$ & $\begin{array}{l}\text { Usulan Baru } \\
\text { mulai Volume } 13 \\
\text { Nomor } 1 \text { Tahun } \\
2018\end{array}$ \\
\hline & 6 & $\begin{array}{l}\text { Al-Adl: Jurnal } \\
\text { Hukum }\end{array}$ & 24770124 & $\begin{array}{l}\text { Universitas Islam } \\
\text { Kalimantan } \\
\text { Muhammad } \\
\text { Aryad Al-Banjari }\end{array}$ & $\begin{array}{l}\text { Reakreditasi Naik } \\
\text { Peringkat dari } \\
\text { Peringkat } 5 \text { ke } \\
\text { Peringkat } 4 \text { mulai } \\
\text { Volume } 12 \\
\text { Nomor } 1 \text { Tahun } \\
2020\end{array}$ \\
\hline & 7 & $\begin{array}{l}\text { Al-Adzka: Jurnal } \\
\text { Ilmiah Pendidikan } \\
\text { Guru Madrasah } \\
\text { Ibtidaiyah }\end{array}$ & $2597937 X$ & $\begin{array}{l}\text { Jurusan PGMI } \\
\text { Fakultas } \\
\text { Tarbiyah dan } \\
\text { Keguruan UIN } \\
\text { Antasari } \\
\text { Banjarmasin }\end{array}$ & $\begin{array}{l}\text { Usulan Baru } \\
\text { mulai Volume } 8 \\
\text { Nomor } 1 \text { Tahun } \\
2018\end{array}$ \\
\hline & 8 & $\begin{array}{l}\text { Al-Bukhari: Jurnal } \\
\text { Ilmu Hadis }\end{array}$ & 26213559 & $\begin{array}{l}\text { Institut Agama } \\
\text { Islam Negeri } \\
\text { Zawiyah Cot Kala } \\
\text { Langsa }\end{array}$ & $\begin{array}{l}\text { Usulan Baru } \\
\text { mulai Volume } 1 \\
\text { Nomor } 1 \text { Tahun } \\
2018\end{array}$ \\
\hline
\end{tabular}




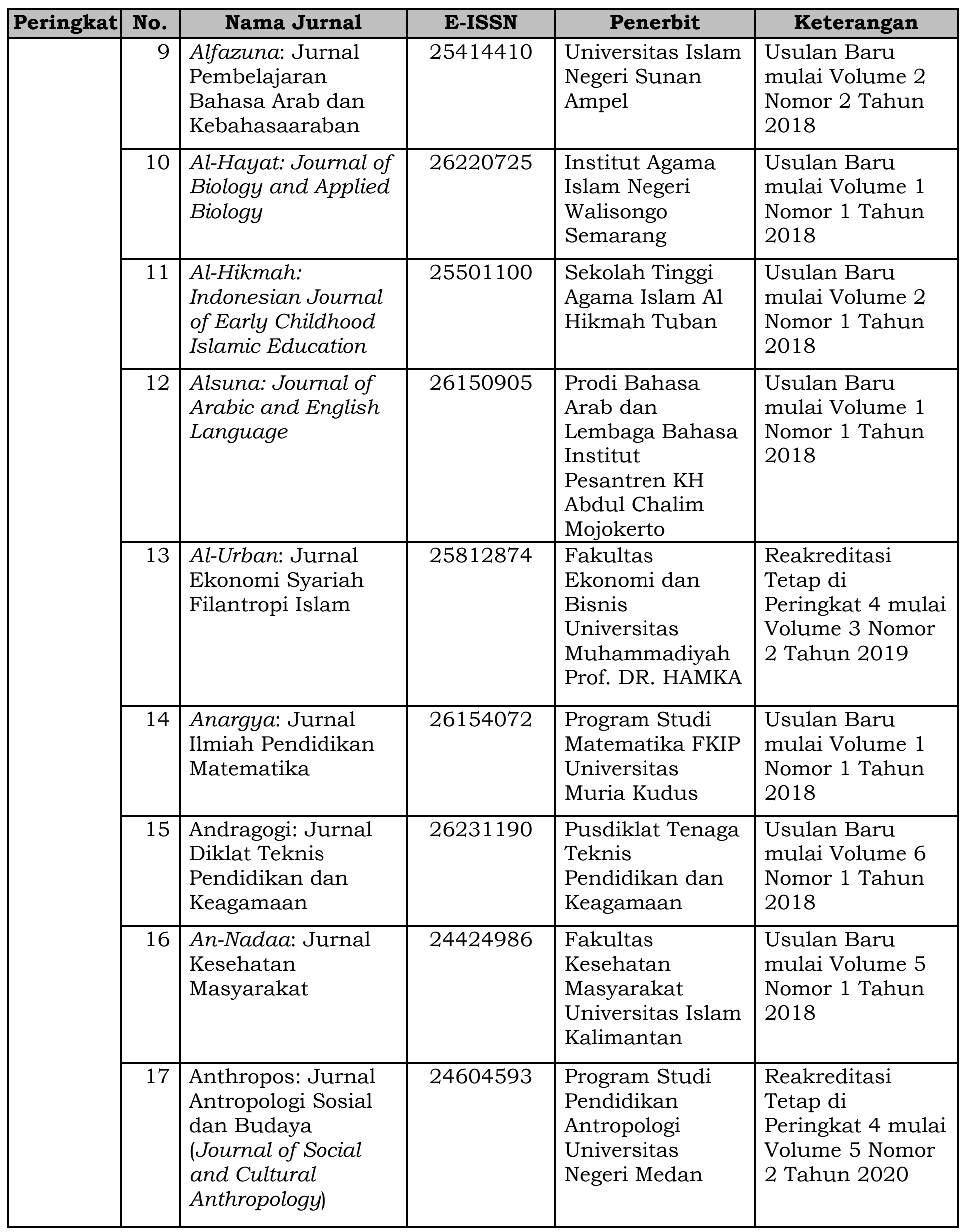

18. Astonjadro ... 


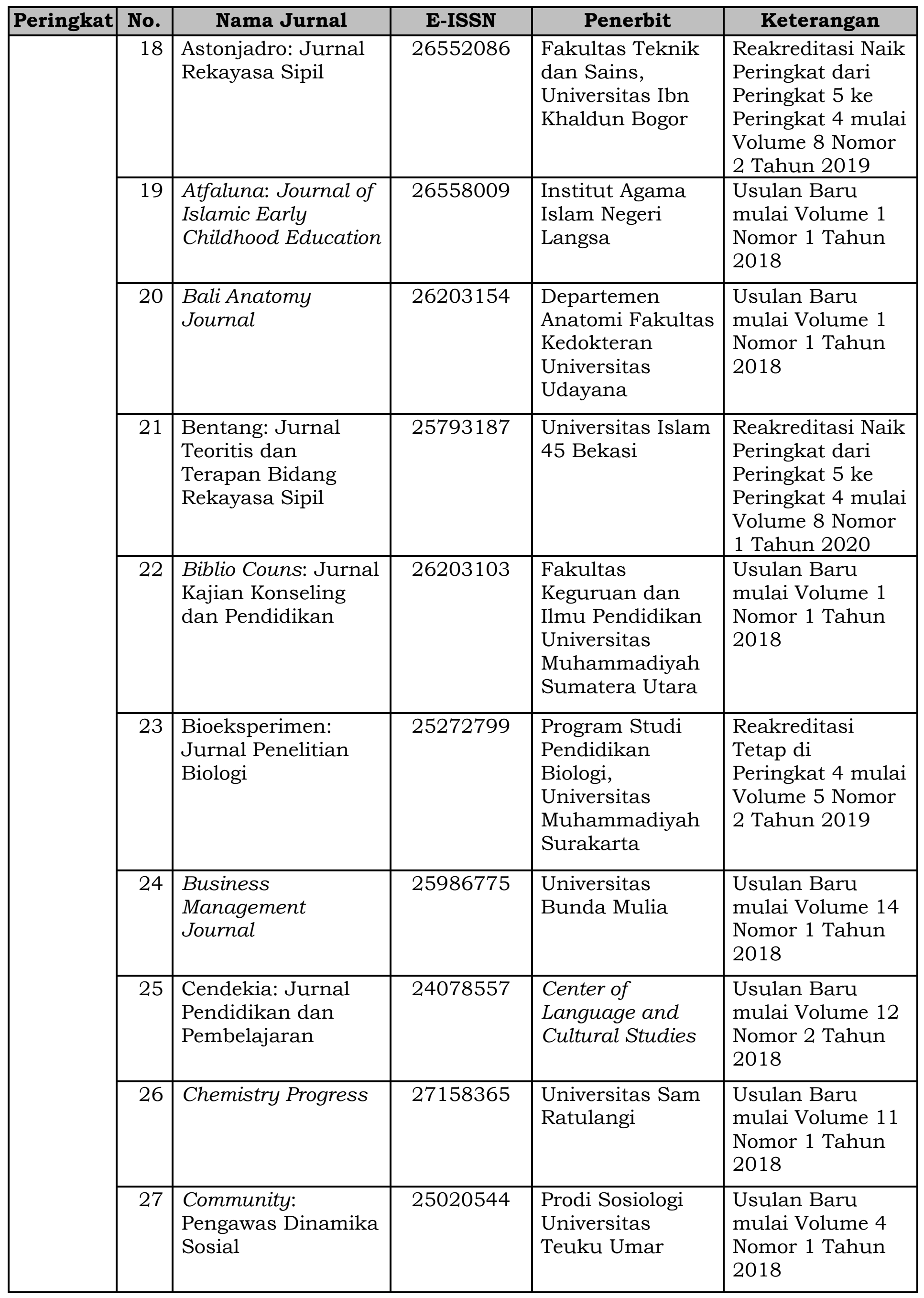




\begin{tabular}{|c|c|c|c|c|c|}
\hline Peringkat & No. & Nama Jurnal & E-ISSN & Penerbit & Keterangan \\
\hline & 28 & $\begin{array}{l}\text { Compton: Jurnal } \\
\text { Ilmiah Pendidikan } \\
\text { Fisika }\end{array}$ & 25795252 & $\begin{array}{l}\text { Prodi Pendidikan } \\
\text { Fisika, FKIP, } \\
\text { Universitas } \\
\text { Sarjanawiyata } \\
\text { Tamansiswa }\end{array}$ & $\begin{array}{l}\text { Reakreditasi Naik } \\
\text { Peringkat dari } \\
\text { Peringkat } 5 \text { ke } \\
\text { Peringkat } 4 \text { mulai } \\
\text { Volume } 6 \text { Nomor } \\
2 \text { Tahun } 2019\end{array}$ \\
\hline & 29 & $\begin{array}{l}\text { Cyberspace: Jurnal } \\
\text { Pendidikan } \\
\text { Teknologi Informasi }\end{array}$ & 25979671 & $\begin{array}{l}\text { Pusat Penelitian } \\
\text { dan Penerbitan } \\
\text { Lembaga } \\
\text { Penelitian dan } \\
\text { Pengabdian } \\
\text { kepada } \\
\text { Masyarakat dan } \\
\text { Pendidikan } \\
\text { Teknologi } \\
\text { Informasi UIN Ar- } \\
\text { Raniry }\end{array}$ & $\begin{array}{l}\text { Usulan Baru } \\
\text { mulai Volume } 2 \\
\text { Nomor } 1 \text { Tahun } \\
2018\end{array}$ \\
\hline & 30 & $\begin{array}{l}\text { De Fermat: Jurnal } \\
\text { Pendidikan } \\
\text { Matematika }\end{array}$ & 26217309 & $\begin{array}{l}\text { Universitas } \\
\text { Balikpapan }\end{array}$ & $\begin{array}{l}\text { Usulan Baru } \\
\text { mulai Volume } 1 \\
\text { Nomor } 1 \text { Tahun } \\
2018\end{array}$ \\
\hline & 31 & $\begin{array}{l}\text { Diakom: Jurnal } \\
\text { Media dan } \\
\text { Komunikasi }\end{array}$ & 26231212 & $\begin{array}{l}\text { Kementerian } \\
\text { Komunikasi dan } \\
\text { Informatika }\end{array}$ & $\begin{array}{l}\text { Usulan Baru } \\
\text { mulai Volume } 1 \\
\text { Nomor } 1 \text { Tahun } \\
2018\end{array}$ \\
\hline & 32 & Diksi & 25796399 & $\begin{array}{l}\text { Fakultas Bahasa } \\
\text { dan Seni } \\
\text { Universitas } \\
\text { Negeri } \\
\text { Yogyakarta }\end{array}$ & $\begin{array}{l}\text { Usulan Baru } \\
\text { mulai Volume } 26 \\
\text { Nomor } 1 \text { Tahun } \\
2018\end{array}$ \\
\hline & 33 & $\begin{array}{l}\text { Dinamika } \\
\text { Kesehatan: Jurnal } \\
\text { Kebidanan dan } \\
\text { Keperawatan }\end{array}$ & 25494058 & $\begin{array}{l}\text { LPPM Universitas } \\
\text { Sari Mulia }\end{array}$ & $\begin{array}{l}\text { Reakreditasi Naik } \\
\text { Peringkat dari } \\
\text { Peringkat } 5 \mathrm{ke} \\
\text { Peringkat } 4 \text { mulai } \\
\text { Volume } 10 \\
\text { Nomor } 2 \text { Tahun } \\
2019\end{array}$ \\
\hline & 34 & $\begin{array}{l}\text { e-Journal Ekonomi } \\
\text { Bisnis dan } \\
\text { Akuntansi }\end{array}$ & 26853523 & $\begin{array}{l}\text { UPT Penerbitan } \\
\text { Universitas } \\
\text { Jember }\end{array}$ & $\begin{array}{l}\text { Usulan Baru } \\
\text { mulai Volume } 5 \\
\text { Nomor } 1 \text { Tahun } \\
2018\end{array}$ \\
\hline & 35 & $\begin{array}{l}\text { Ekonomika Syariah: } \\
\text { Journal of Economic } \\
\text { Studies }\end{array}$ & 26148110 & IAIN Bukittinggi & $\begin{array}{l}\text { Usulan Baru } \\
\text { mulai Volume } 2 \\
\text { Nomor } 1 \text { Tahun } \\
2018\end{array}$ \\
\hline & 36 & Electro Luceat & 25974467 & $\begin{array}{l}\text { LPPM Politeknik } \\
\text { Katolik Saint } \\
\text { Paul Soorng }\end{array}$ & $\begin{array}{l}\text { Usulan Baru } \\
\text { mulai Volume } 4 \\
\text { Nomor } 1 \text { Tahun } \\
2018\end{array}$ \\
\hline
\end{tabular}




\begin{tabular}{|c|c|c|c|c|c|}
\hline \begin{tabular}{|l|} 
Peringkat \\
\end{tabular} & No. & Nama Jurnal & E-ISSN & Penerbit & Keterangan \\
\hline & 37 & $\begin{array}{l}\text { Elementary School: } \\
\text { Jurnal Pendidikan } \\
\text { dan Pembelajaran } \\
\text { ke SD-an }\end{array}$ & 25024264 & $\begin{array}{l}\text { Universitas PGRI } \\
\text { Yogyakarta }\end{array}$ & $\begin{array}{l}\text { Reakreditasi Naik } \\
\text { Peringkat dari } \\
\text { Peringkat } 6 \text { ke } \\
\text { Peringkat } 4 \text { mulai } \\
\text { Volume } 5 \text { Nomor } \\
2 \text { Tahun } 2018 \\
\end{array}$ \\
\hline & 38 & $\begin{array}{l}\text { English Teaching } \\
\text { Journal: A Journal } \\
\text { of English Literature, } \\
\text { Language, and } \\
\text { Education }\end{array}$ & 26864738 & $\begin{array}{l}\text { Universitas PGRI } \\
\text { Madiun }\end{array}$ & $\begin{array}{l}\text { Usulan Baru } \\
\text { mulai Volume } 6 \\
\text { Nomor } 1 \text { Tahun } \\
2018\end{array}$ \\
\hline & 39 & $\begin{array}{l}\text { Enlighten: Jurnal } \\
\text { Bimbingan } \\
\text { Konseling Islam }\end{array}$ & 26228920 & IAIN Langsa & $\begin{array}{l}\text { Usulan Baru } \\
\text { mulai Volume } 1 \\
\text { Nomor } 1 \text { Tahun } \\
2018\end{array}$ \\
\hline & 40 & $\begin{array}{l}\text { Equilibrium: Jurnal } \\
\text { Ekonomi, } \\
\text { Manajemen, } \\
\text { Akuntansi }\end{array}$ & 25989952 & $\begin{array}{l}\text { LPPM Universitas } \\
\text { Wijaya Kusuma } \\
\text { Surabaya }\end{array}$ & $\begin{array}{l}\text { Usulan Baru } \\
\text { mulai Volume } 14 \\
\text { Nomor } 1 \text { Tahun } \\
2018\end{array}$ \\
\hline & 41 & $\begin{array}{l}\text { Fidei: Jurnal Teologi } \\
\text { Sistematika dan } \\
\text { Praktika }\end{array}$ & 26218135 & $\begin{array}{l}\text { Sekolah Tinggi } \\
\text { Teologi } \\
\text { Tawangmangu }\end{array}$ & $\begin{array}{l}\text { Usulan Baru } \\
\text { mulai Volume } 1 \\
\text { Nomor } 1 \text { Tahun } \\
2018\end{array}$ \\
\hline & 42 & $\begin{array}{l}\text { Fullerene Journal of } \\
\text { Chemistry }\end{array}$ & 25985868 & $\begin{array}{l}\text { Jurusan Kimia, } \\
\text { Universitas } \\
\text { Negeri Manado }\end{array}$ & $\begin{array}{l}\text { Reakreditasi } \\
\text { Tetap di } \\
\text { Peringkat } 4 \text { mulai } \\
\text { Volume } 4 \text { Nomor } \\
2 \text { Tahun } 2019\end{array}$ \\
\hline & 43 & $\begin{array}{l}\text { Ghidza: Jurnal Gizi } \\
\text { dan Kesehatan }\end{array}$ & 26227622 & $\begin{array}{l}\text { Universitas } \\
\text { Tadulako }\end{array}$ & $\begin{array}{l}\text { Usulan Baru } \\
\text { mulai Volume } 2 \\
\text { Nomor } 1 \text { Tahun } \\
2018\end{array}$ \\
\hline & 44 & $\begin{array}{l}\text { Golden Age: Jurnal } \\
\text { Ilmiah Tumbuh } \\
\text { Kembang Anak Usia } \\
\text { Dini }\end{array}$ & 25023519 & $\begin{array}{l}\text { Universitas Islam } \\
\text { Negeri Sunan } \\
\text { Kalijaga }\end{array}$ & $\begin{array}{l}\text { Usulan Baru } \\
\text { mulai Volume } 3 \\
\text { Nomor } 1 \text { Tahun } \\
2018\end{array}$ \\
\hline
\end{tabular}

45. Hermeneutika ... 


\begin{tabular}{|c|c|c|c|c|c|}
\hline \begin{tabular}{|l|} 
Peringkat \\
\end{tabular} & No. & Nama Jurnal & E-ISSN & Penerbit & Keterangan \\
\hline & 45 & $\begin{array}{l}\text { Hermeneutika: } \\
\text { Jurnal } \\
\text { Hermeneutika }\end{array}$ & 26140055 & $\begin{array}{l}\text { Jurusan } \\
\text { Pendidikan } \\
\text { Sosiologi FKIP } \\
\text { Universitas } \\
\text { Sultan Ageng } \\
\text { Tirtayasa } \\
\text { Bekerjasama } \\
\text { dengan Asosiasi } \\
\text { Program Studi } \\
\text { Sosiologi } \\
\text { Indonesia (APSSI) } \\
\text { dan Ikatan } \\
\text { Sosiologi } \\
\text { Indonesia (ISI) }\end{array}$ & $\begin{array}{l}\text { Usulan Baru } \\
\text { mulai Volume } 4 \\
\text { Nomor } 1 \text { Tahun } \\
2018\end{array}$ \\
\hline & 46 & $\begin{array}{l}\text { IJCA (Indonesian } \\
\text { Journal of Chemical } \\
\text { Analysis) }\end{array}$ & 26227126 & $\begin{array}{l}\text { Universitas Islam } \\
\text { Indonesia }\end{array}$ & $\begin{array}{l}\text { Usulan Baru } \\
\text { mulai Volume } 1 \\
\text { Nomor } 1 \text { Tahun } \\
2018\end{array}$ \\
\hline & 47 & $\begin{array}{l}\text { IJID (International } \\
\text { Journal on } \\
\text { Informatics for } \\
\text { Development) }\end{array}$ & 25497448 & $\begin{array}{l}\text { Fakultas Sains } \\
\text { dan Teknologi } \\
\text { Universitas Islam } \\
\text { Negeri Sunan } \\
\text { Kalijaga } \\
\text { Yogyakarta } \\
\end{array}$ & $\begin{array}{l}\text { Usulan Baru } \\
\text { mulai Volume } 6 \\
\text { Nomor } 2 \text { Tahun } \\
2017\end{array}$ \\
\hline & 48 & $\begin{array}{l}\text { IJOLTL (Indonesian } \\
\text { Journal of Language } \\
\text { Teaching and } \\
\text { Linguistics) }\end{array}$ & 25028278 & $\begin{array}{l}\text { Center of } \\
\text { Language and } \\
\text { Cultural Studies }\end{array}$ & $\begin{array}{l}\text { Usulan Baru } \\
\text { mulai Volume } 3 \\
\text { Nomor } 2 \text { Tahun } \\
2018\end{array}$ \\
\hline & 49 & $\begin{array}{l}\text { Imara: Jurnal Riset } \\
\text { Ekonomi Islam }\end{array}$ & 26221918 & $\begin{array}{l}\text { Institut Agama } \\
\text { Islam Negeri } \\
\text { Batusangkar }\end{array}$ & $\begin{array}{l}\text { Usulan Baru } \\
\text { mulai Volume } 2 \\
\text { Nomor } 1 \text { Tahun } \\
2018\end{array}$ \\
\hline & 50 & $\begin{array}{l}\text { Indonesia } \\
\text { Accounting Journal }\end{array}$ & 26866609 & $\begin{array}{l}\text { Universitas Sam } \\
\text { Ratulangi }\end{array}$ & $\begin{array}{l}\text { Usulan Baru } \\
\text { mulai Volume } 1 \\
\text { Nomor } 1 \text { Tahun } \\
2019\end{array}$ \\
\hline & 51 & $\begin{array}{l}\text { Indonesian Journal } \\
\text { of Agricultural } \\
\text { Research }\end{array}$ & 26155842 & $\begin{array}{l}\text { Fakultas } \\
\text { Pertanian } \\
\text { Universitas } \\
\text { Sumatera Utara }\end{array}$ & $\begin{array}{l}\text { Usulan Baru } \\
\text { mulai Volume } 1 \\
\text { Nomor } 1 \text { Tahun } \\
2018\end{array}$ \\
\hline & 52 & $\begin{array}{l}\text { Indonesian Journal } \\
\text { of Learning } \\
\text { Education and } \\
\text { Counseling }\end{array}$ & 26228068 & $\begin{array}{l}\text { Institute for } \\
\text { Learning } \\
\text { Innovation and } \\
\text { Counseling }\end{array}$ & $\begin{array}{l}\text { Usulan Baru } \\
\text { mulai Volume } 1 \\
\text { Nomor } 1 \text { Tahun } \\
2018\end{array}$ \\
\hline & 53 & $\begin{array}{l}\text { Indonesian Journal } \\
\text { of Physical Medicine } \\
\& \text { Rehabilitation }\end{array}$ & 26217678 & $\begin{array}{l}\text { Perhimpunan } \\
\text { Besar } \\
\text { Kedokteran Fisik } \\
\text { dan Rehabilitasi } \\
\text { Indonesia }\end{array}$ & $\begin{array}{l}\text { Usulan Baru } \\
\text { mulai Volume } 6 \\
\text { Nomor } 2 \text { Tahun } \\
2017\end{array}$ \\
\hline
\end{tabular}




\begin{tabular}{|c|c|c|c|c|c|}
\hline Peringkat & No. & Nama Jurnal & E-ISSN & Penerbit & Keterangan \\
\hline & 54 & $\begin{array}{l}\text { Infomatek: Jurnal } \\
\text { Informatika, } \\
\text { Manajemen dan } \\
\text { Teknologi }\end{array}$ & 26147807 & $\begin{array}{l}\text { Fakultas Teknik } \\
\text { Universitas } \\
\text { Pasundan }\end{array}$ & $\begin{array}{l}\text { Usulan Baru } \\
\text { mulai Volume } 20 \\
\text { Nomor } 1 \text { Tahun } \\
2018\end{array}$ \\
\hline & 55 & $\begin{array}{l}\text { Inform: Jurnal } \\
\text { Ilmiah Bidang } \\
\text { Teknologi Informasi } \\
\text { dan Komunikasi }\end{array}$ & 25810367 & $\begin{array}{l}\text { Program Studi } \\
\text { Teknik } \\
\text { Informatika } \\
\text { Universitas } \\
\text { Dr.Soetomo }\end{array}$ & $\begin{array}{l}\text { Usulan Baru } \\
\text { mulai Volume } 3 \\
\text { Nomor } 2 \text { Tahun } \\
2018\end{array}$ \\
\hline & 56 & $\begin{array}{l}\text { Informatika: Jurnal } \\
\text { Informatika, } \\
\text { Manajemen dan } \\
\text { Komputer }\end{array}$ & 25803042 & $\begin{array}{l}\text { P3M STMIK } \\
\text { Dumai }\end{array}$ & $\begin{array}{l}\text { Usulan Baru } \\
\text { mulai Volume } 10 \\
\text { Nomor } 1 \text { Tahun } \\
2018\end{array}$ \\
\hline & 57 & $\begin{array}{l}\text { International } \\
\text { Journal of } \\
\text { Economics, Business } \\
\text { and Accounting } \\
\text { Research (IJEBAR) }\end{array}$ & 26141280 & $\begin{array}{l}\text { LPPM STIE AAS } \\
\text { Surakarta }\end{array}$ & $\begin{array}{l}\text { Usulan Baru } \\
\text { mulai Volume } 2 \\
\text { Nomor } 1 \text { Tahun } \\
2018\end{array}$ \\
\hline & 58 & $\begin{array}{l}\text { Intiqad: Jurnal } \\
\text { Agama dan } \\
\text { Pendidikan Islam }\end{array}$ & 25980033 & $\begin{array}{l}\text { Universitas } \\
\text { Muhammadiyash } \\
\text { Sumatera Utara }\end{array}$ & $\begin{array}{l}\text { Reakreditasi } \\
\text { Tetap di } \\
\text { Peringkat } 4 \text { mulai } \\
\text { Volume } 11 \\
\text { Nomor } 2 \text { Tahun } \\
2019\end{array}$ \\
\hline & 59 & $\begin{array}{l}\text { Islamic Studies } \\
\text { Journal for Social } \\
\text { Transformation }\end{array}$ & 26860619 & $\begin{array}{l}\text { Lembaga } \\
\text { Penelitian dan } \\
\text { Pengabdian } \\
\text { kepada } \\
\text { Masyarakat IAIN } \\
\text { Pekalongan }\end{array}$ & $\begin{array}{l}\text { Reakreditasi } \\
\text { Tetap di } \\
\text { Peringkat } 4 \text { mulai } \\
\text { Volume } 3 \text { Nomor } \\
2 \text { Tahun } 2019\end{array}$ \\
\hline & 60 & $\begin{array}{l}\text { JCES (Journal of } \\
\text { Character Education } \\
\text { Society) }\end{array}$ & 26143666 & $\begin{array}{l}\text { Universitas } \\
\text { Muhammadiyah } \\
\text { Mataram }\end{array}$ & $\begin{array}{l}\text { Usulan Baru } \\
\text { mulai Volume } 1 \\
\text { Nomor } 2 \text { Tahun } \\
2018\end{array}$ \\
\hline & 61 & $\begin{array}{l}\text { JECCE (Journal of } \\
\text { Early Childhood } \\
\text { Care and Education) }\end{array}$ & 26151413 & $\begin{array}{l}\text { Universitas } \\
\text { Ahmad Dahlan }\end{array}$ & $\begin{array}{l}\text { Usulan Baru } \\
\text { mulai Volume } 1 \\
\text { Nomor } 1 \text { Tahun } \\
2018\end{array}$ \\
\hline & 62 & Jendela Olahraga & 25797662 & $\begin{array}{l}\text { Universitas PGRI } \\
\text { Semarang }\end{array}$ & $\begin{array}{l}\text { Reakreditasi Naik } \\
\text { Peringkat dari } \\
\text { Peringkat } 5 \text { ke } \\
\text { Peringkat } 4 \text { mulai } \\
\text { Volume } 5 \text { Nomor } \\
1 \text { Tahun } 2020\end{array}$ \\
\hline & 63 & $\begin{array}{l}\text { JGISE-Journal of } \\
\text { Geospatial } \\
\text { Information Science } \\
\text { and Engineerin }\end{array}$ & 26231182 & $\begin{array}{l}\text { Universitas } \\
\text { Gadjah Mada }\end{array}$ & $\begin{array}{l}\text { Usulan Baru } \\
\text { mulai Volume } 1 \\
\text { Nomor } 1 \text { Tahun } \\
2018\end{array}$ \\
\hline
\end{tabular}




\begin{tabular}{|c|c|c|c|c|c|}
\hline \begin{tabular}{|l|} 
Peringkat \\
\end{tabular} & No. & Nama Jurnal & E-ISSN & Penerbit & Keterangan \\
\hline & 64 & $\begin{array}{l}\text { JIPI (Jurnal Ilmiah } \\
\text { Penelitian dan } \\
\text { Pembelajaran } \\
\text { Informatika) }\end{array}$ & 25408984 & $\begin{array}{l}\text { Prodi Pendidikan } \\
\text { Teknologi } \\
\text { Informasi STKIP } \\
\text { PGRI } \\
\text { Tulungagung }\end{array}$ & $\begin{array}{l}\text { Reakreditasi } \\
\text { Tetap di } \\
\text { Peringkat } 4 \\
\text { mulai Volume } 4 \\
\text { Nomor } 2 \text { Tahun } \\
2019 \\
\end{array}$ \\
\hline & 65 & $\begin{array}{l}\text { JIRE (Jurnal } \\
\text { Informatika dan } \\
\text { Rekayasa } \\
\text { Elektronik) }\end{array}$ & 26206900 & $\begin{array}{l}\text { Lembaga } \\
\text { Penelitian dan } \\
\text { pengabdian } \\
\text { Masyarakat } \\
\text { STMIK Lombok } \\
\end{array}$ & $\begin{array}{l}\text { Usulan Baru } \\
\text { mulai Volume } 1 \\
\text { Nomor } 1 \text { Tahun } \\
2018\end{array}$ \\
\hline & 66 & $\begin{array}{l}\text { Journal of } \\
\text { Administration and } \\
\text { Educational } \\
\text { Management } \\
\text { (ALIGNMENT) }\end{array}$ & 25985159 & $\begin{array}{l}\text { Institut } \\
\text { Penelitian } \\
\text { Matematika, } \\
\text { Komputer, } \\
\text { Keperawatan, } \\
\text { Pendidikan dan } \\
\text { Ekonomi } \\
\text { (IPM2KPE) }\end{array}$ & $\begin{array}{l}\text { Usulan Baru } \\
\text { mulai Volume } 1 \\
\text { Nomor } 1 \text { Tahun } \\
2018\end{array}$ \\
\hline & 67 & $\begin{array}{l}\text { Journal of } \\
\text { Agromedicine and } \\
\text { Medical Science }\end{array}$ & 24609048 & $\begin{array}{l}\text { UPT Penerbitan } \\
\text { Universitas } \\
\text { Jember }\end{array}$ & $\begin{array}{l}\text { Usulan Baru } \\
\text { mulai Volume } 4 \\
\text { Nomor } 1 \text { Tahun } \\
2018\end{array}$ \\
\hline & 68 & $\begin{array}{l}\text { Journal of Earth } \\
\text { Energy Science, } \\
\text { Engineering, and } \\
\text { Technology }\end{array}$ & E26140268 & $\begin{array}{l}\text { Universitas } \\
\text { Trisakti }\end{array}$ & $\begin{array}{l}\text { Usulan Baru } \\
\text { mulai Volume } 1 \\
\text { Nomor } 2 \text { Tahun } \\
2018\end{array}$ \\
\hline & 69 & $\begin{array}{l}\text { Journal of Education } \\
\text { and Instruction } \\
\text { (JOEAI) }\end{array}$ & 26148617 & $\begin{array}{l}\text { Institut } \\
\text { Penelitian } \\
\text { Matematika, } \\
\text { Komputer, } \\
\text { Keperawatan, } \\
\text { Pendidikan dan } \\
\text { Ekonomi } \\
\text { (IPM2KPE) }\end{array}$ & $\begin{array}{l}\text { Usulan Baru } \\
\text { mulai Volume } 1 \\
\text { Nomor } 1 \text { Tahun } \\
2018\end{array}$ \\
\hline & 70 & $\begin{array}{l}\text { Journal of English } \\
\text { Education and } \\
\text { Teaching }\end{array}$ & 26225867 & $\begin{array}{l}\text { Fakultas } \\
\text { Keguruan dan } \\
\text { Ilmu Pendidikan } \\
\text { Universitas } \\
\text { Bengkulu }\end{array}$ & $\begin{array}{l}\text { Reakreditasi Naik } \\
\text { Peringkat dari } \\
\text { Peringkat } 5 \text { ke } \\
\text { Peringkat } 4 \text { mulai } \\
\text { Volume } 3 \text { Nomor } \\
4 \text { Tahun } 2019\end{array}$ \\
\hline & 71 & $\begin{array}{l}\text { Journal of } \\
\text { Information } \\
\text { Technology and } \\
\text { Computer Science } \\
\text { (INTECOMS) }\end{array}$ & 26141574 & $\begin{array}{l}\text { Institut } \\
\text { Penelitian } \\
\text { Matematika, } \\
\text { Komputer, } \\
\text { Keperawatan, } \\
\text { Pendidikan dan } \\
\text { Ekonomi } \\
\text { (IPM2KPE) }\end{array}$ & $\begin{array}{l}\text { Usulan Baru } \\
\text { mulai Volume } 1 \\
\text { Nomor } 1 \text { Tahun } \\
2018\end{array}$ \\
\hline
\end{tabular}




\begin{tabular}{|c|c|c|c|c|c|}
\hline Peringkat & No. & Nama Jurnal & E-ISSN & Penerbit & Keterangan \\
\hline & 72 & $\begin{array}{l}\text { Journal of Integrated } \\
\text { System }\end{array}$ & 26217104 & $\begin{array}{l}\text { Program Studi } \\
\text { Teknik Industri, } \\
\text { Universitas } \\
\text { Kristen } \\
\text { Maranatha }\end{array}$ & $\begin{array}{l}\text { Usulan Baru } \\
\text { mulai Volume } 1 \\
\text { Nomor } 1 \text { Tahun } \\
2018\end{array}$ \\
\hline & 73 & $\begin{array}{l}\text { Journal of Livestock } \\
\text { and Animal Health }\end{array}$ & 26552159 & $\begin{array}{l}\text { Politeknik } \\
\text { Pertaninan } \\
\text { Negeri } \\
\text { Payakumbuh }\end{array}$ & $\begin{array}{l}\text { Usulan Baru } \\
\text { mulai Volume } 1 \\
\text { Nomor } 1 \text { Tahun } \\
2018\end{array}$ \\
\hline & 74 & $\begin{array}{l}\text { J-SAKTI (Jurnal } \\
\text { Sains Komputer } \\
\text { dan Informatika) }\end{array}$ & 25497200 & $\begin{array}{l}\text { STIKOM Tunas } \\
\text { Pematang } \\
\text { Siantar }\end{array}$ & $\begin{array}{l}\text { Reakreditasi Naik } \\
\text { Peringkat dari } \\
\text { Peringkat } 5 \text { ke } \\
\text { Peringkat } 4 \text { mulai } \\
\text { Volume } 3 \text { Nomor } \\
2 \text { Tahun } 2019 \\
\end{array}$ \\
\hline & 75 & $\begin{array}{l}\text { JTI: Jurnal Teknik } \\
\text { Industri }\end{array}$ & 27146235 & $\begin{array}{l}\text { Industrial } \\
\text { Engineering } \\
\text { Department } \\
\text { Universitas Islam } \\
\text { Negeri Sultan } \\
\text { Syarif Kasim } \\
\text { Riau }\end{array}$ & $\begin{array}{l}\text { Usulan Baru } \\
\text { mulai Volume } 1 \\
\text { Nomor } 2 \text { Tahun } \\
2018\end{array}$ \\
\hline & 76 & Jurnal Agribest & 26154862 & $\begin{array}{l}\text { Universitas } \\
\text { Muhammadiyah } \\
\text { Jember }\end{array}$ & $\begin{array}{l}\text { Reakreditasi Naik } \\
\text { Peringkat dari } \\
\text { Peringkat } 5 \text { ke } \\
\text { Peringkat } 4 \text { mulai } \\
\text { Volume } 3 \text { Nomor } \\
2 \text { Tahun } 2019\end{array}$ \\
\hline & 77 & $\begin{array}{l}\text { Jurnal Arsitektur } \\
\text { Zonasi }\end{array}$ & 26209934 & $\begin{array}{l}\text { Universitas } \\
\text { Pendidikan } \\
\text { Indonesia }\end{array}$ & $\begin{array}{l}\text { Usulan Baru } \\
\text { mulai Volume } 1 \\
\text { Nomor } 1 \text { Tahun } \\
2018\end{array}$ \\
\hline & 78 & Jurnal Ecosolum & $2654430 X$ & $\begin{array}{l}\text { Fakultas } \\
\text { Pertanian, } \\
\text { Universitas } \\
\text { Hasanuddin }\end{array}$ & $\begin{array}{l}\text { Usulan Baru } \\
\text { mulai Volume } 7 \\
\text { Nomor } 1 \text { Tahun } \\
2018\end{array}$ \\
\hline & 79 & $\begin{array}{l}\text { Jurnal Entrepreneur } \\
\text { dan } \\
\text { Entrepreneurship }\end{array}$ & 25809393 & $\begin{array}{l}\text { Universitas } \\
\text { Ciputra } \\
\text { Surabaya }\end{array}$ & $\begin{array}{l}\text { Reakreditasi } \\
\text { Tetap di } \\
\text { Peringkat } 4 \text { mulai } \\
\text { Volume } 8 \text { Nomor } \\
2 \text { Tahun } 2019\end{array}$ \\
\hline & 80 & $\begin{array}{l}\text { Jurnal Fundadikdas } \\
\text { (Fundamental } \\
\text { Pendidikan Dasar) }\end{array}$ & 26141620 & $\begin{array}{l}\text { Universitas } \\
\text { Ahmad Dahlan }\end{array}$ & $\begin{array}{l}\text { Usulan Baru } \\
\text { mulai Volume } 1 \\
\text { Nomor } 1 \text { Tahun } \\
2018\end{array}$ \\
\hline & 81 & $\begin{array}{l}\text { Jurnal Geofisika } \\
\text { Eksplorasi }\end{array}$ & 26856182 & $\begin{array}{l}\text { Universitas } \\
\text { Lampung }\end{array}$ & $\begin{array}{l}\text { Usulan Baru } \\
\text { mulai Volume } 4 \\
\text { Nomor } 1 \text { Tahun } \\
2018\end{array}$ \\
\hline
\end{tabular}

82. Jurnal ... 


\begin{tabular}{|c|c|c|c|c|c|}
\hline \begin{tabular}{|l|} 
Peringkat \\
\end{tabular} & No. & Nama Jurnal & E-ISSN & Penerbit & Keterangan \\
\hline & 82 & Jurnal Gizi & 25804847 & $\begin{array}{l}\text { Program Studi } \\
\text { Gizi Fakultas } \\
\text { Ilmu } \\
\text { Keperawatan dan } \\
\text { Kesehatan } \\
\text { Universitas } \\
\text { Muhammadiyah } \\
\text { Semarang }\end{array}$ & $\begin{array}{l}\text { Reakreditasi Naik } \\
\text { Peringkat dari } \\
\text { Peringkat } 5 \text { ke } \\
\text { Peringkat } 4 \text { mulai } \\
\text { Volume } 8 \text { Nomor } \\
2 \text { Tahun } 2019\end{array}$ \\
\hline & 83 & $\begin{array}{l}\text { Jurnal HPJI } \\
\text { (Himpunan } \\
\text { Pengembangan } \\
\text { Jalan Indonesia) }\end{array}$ & 26544873 & $\begin{array}{l}\text { Universitas } \\
\text { Katolik } \\
\text { Parahyangan }\end{array}$ & $\begin{array}{l}\text { Usulan Baru } \\
\text { mulai Volume } 4 \\
\text { Nomor } 1 \text { Tahun } \\
2018\end{array}$ \\
\hline & 84 & $\begin{array}{l}\text { Jurnal Hukum } \\
\text { Bisnis Bonum } \\
\text { Commune }\end{array}$ & 26229668 & $\begin{array}{l}\text { Universitas } 17 \\
\text { Agustus } 1945 \\
\text { Surabaya }\end{array}$ & $\begin{array}{l}\text { Usulan Baru } \\
\text { mulai Volume } 1 \\
\text { Nomor } 1 \text { Tahun } \\
2018\end{array}$ \\
\hline & 85 & $\begin{array}{l}\text { Jurnal Hukum } \\
\text { Magnum Opus }\end{array}$ & $2623274 X$ & $\begin{array}{l}\text { Universitas } 17 \\
\text { Agustus } 1945 \\
\text { Surabaya }\end{array}$ & $\begin{array}{l}\text { Usulan Baru } \\
\text { mulai Volume } 1 \\
\text { Nomor } 1 \text { Tahun } \\
2018\end{array}$ \\
\hline & 86 & $\begin{array}{l}\text { Jurnal ICMES: The } \\
\text { Journal of Middle } \\
\text { East Studies }\end{array}$ & 26217341 & $\begin{array}{l}\text { Indonesia Center } \\
\text { for Middle East } \\
\text { Studies }\end{array}$ & $\begin{array}{l}\text { Usulan Baru } \\
\text { mulai Volume } 2 \\
\text { Nomor } 1 \text { Tahun } \\
2018\end{array}$ \\
\hline & 87 & $\begin{array}{l}\text { Jurnal Ilmiah } \\
\text { Fonema: Jurnal } \\
\text { Edukasi Bahasa } \\
\text { dan Sastra } \\
\text { Indonesia }\end{array}$ & 26212900 & $\begin{array}{l}\text { Universitas } \\
\text { Soetomo } \\
\text { Surabaya }\end{array}$ & $\begin{array}{l}\text { Usulan Baru } \\
\text { mulai Volume } 1 \\
\text { Nomor } 1 \text { Tahun } \\
2018\end{array}$ \\
\hline & 88 & $\begin{array}{l}\text { Jurnal Ilmiah } \\
\text { Informatika }\end{array}$ & 25496301 & $\begin{array}{l}\text { Universitas } \\
\text { Ibrahimy }\end{array}$ & $\begin{array}{l}\text { Usulan Baru } \\
\text { mulai Volume } 3 \\
\text { Nomor } 1 \text { Tahun } \\
2018\end{array}$ \\
\hline & 89 & $\begin{array}{l}\text { Jurnal Ilmiah } \\
\text { Kesehatan (Journal } \\
\text { of Health Sciences) }\end{array}$ & 24773948 & $\begin{array}{l}\text { Universitas } \\
\text { Nahdlatul Ulama } \\
\text { Surabaya }\end{array}$ & $\begin{array}{l}\text { Reakreditasi Naik } \\
\text { Peringkat dari } \\
\text { Peringkat } 5 \text { ke } \\
\text { Peringkat } 4 \text { mulai } \\
\text { Volume } 13 \\
\text { Nomor } 1 \text { Tahun } \\
2020\end{array}$ \\
\hline & 90 & $\begin{array}{l}\text { Jurnal Ilmiah } \\
\text { Permas: Jurnal } \\
\text { Ilmiah STIKES } \\
\text { Kendal }\end{array}$ & 25498134 & $\begin{array}{l}\text { LPPM STIKES } \\
\text { Kendal }\end{array}$ & $\begin{array}{l}\text { Reakreditasi } \\
\text { Tetap di } \\
\text { Peringkat } 4 \text { mulai } \\
\text { Volume } 10 \\
\text { Nomor } 1 \text { Tahun } \\
2020\end{array}$ \\
\hline
\end{tabular}

91. Jurnal ... 


\begin{tabular}{|c|c|c|c|c|c|}
\hline Peringkat & No. & Nama Jurnal & E-ISSN & Penerbit & Keterangan \\
\hline & 91 & Jurnal Ilmiah Platax & 23023589 & $\begin{array}{l}\text { Fakultas } \\
\text { Perikanan Dan } \\
\text { Ilmu Kelautan, } \\
\text { Universitas Sam } \\
\text { Ratulangi }\end{array}$ & $\begin{array}{l}\text { Reakreditasi } \\
\text { Tetap di } \\
\text { Peringkat } 4 \text { mulai } \\
\text { Volume } 8 \text { Nomor } \\
1 \text { Tahun } 2020\end{array}$ \\
\hline & 92 & $\begin{array}{l}\text { Jurnal Ilmiah Poli } \\
\text { Bisnis }\end{array}$ & 26561212 & $\begin{array}{l}\text { Politeknik Negeri } \\
\text { Padang }\end{array}$ & $\begin{array}{l}\text { Usulan Baru } \\
\text { mulai Volume } 10 \\
\text { Nomor } 1 \text { Tahun } \\
2018\end{array}$ \\
\hline & 93 & $\begin{array}{l}\text { Jurnal Ilmiah } \\
\text { Universitas } \\
\text { Batanghari Jambi }\end{array}$ & 25494236 & $\begin{array}{l}\text { Lembaga } \\
\text { Penelitian dan } \\
\text { Pengabdian pada } \\
\text { Masyarakat, } \\
\text { Universitas } \\
\text { Batanghari }\end{array}$ & $\begin{array}{l}\text { Reakreditasi Naik } \\
\text { Peringkat dari } \\
\text { Peringkat } 5 \text { ke } \\
\text { Peringkat } 4 \text { mulai } \\
\text { Volume } 20 \\
\text { Nomor } 1 \text { Tahun } \\
2020\end{array}$ \\
\hline & 94 & $\begin{array}{l}\text { Jurnal Ilmu } \\
\text { Kelautan } \\
\text { Kepulauan }\end{array}$ & $2620570 X$ & $\begin{array}{l}\text { Program Studi } \\
\text { Ilmu Kelautan. } \\
\text { Fakultas } \\
\text { Perikanan dan } \\
\text { Kelautan. } \\
\text { Universitas } \\
\text { Khairun, Ternate }\end{array}$ & $\begin{array}{l}\text { Usulan Baru } \\
\text { mulai Volume } 1 \\
\text { Nomor } 1 \text { Tahun } \\
2018\end{array}$ \\
\hline & 95 & $\begin{array}{l}\text { Jurnal Ilmu } \\
\text { Keperawatan } \\
\text { Medikal Bedah }\end{array}$ & 26212986 & $\begin{array}{l}\text { Persatuan } \\
\text { Perawat Nasional } \\
\text { Indonesia (PPNI) } \\
\text { Jawa Tengah }\end{array}$ & $\begin{array}{l}\text { Usulan Baru } \\
\text { mulai Volume } 1 \\
\text { Nomor } 1 \text { Tahun } \\
2018\end{array}$ \\
\hline & 96 & Jurnal Iqtisaduna & 25500295 & $\begin{array}{l}\text { Fakultas } \\
\text { Ekonomi dan } \\
\text { Bisnis Islam UIN } \\
\text { Alaudddin } \\
\text { Makassar }\end{array}$ & $\begin{array}{l}\text { Reakreditasi } \\
\text { Tetap di } \\
\text { Peringkat } 4 \text { mulai } \\
\text { Volume } 5 \text { Nomor } \\
2 \text { Tahun } 2019\end{array}$ \\
\hline & 97 & $\begin{array}{l}\text { Jurnal Justisia: } \\
\text { Jurnal Ilmu } \\
\text { Hukum, } \\
\text { Perundang- } \\
\text { undangan dan } \\
\text { Pranata Sosial } \\
\end{array}$ & 26145642 & $\begin{array}{l}\text { Universitas Islam } \\
\text { Negeri Ar-Raniry } \\
\text { Banda Aceh }\end{array}$ & $\begin{array}{l}\text { Usulan Baru } \\
\text { mulai Volume } 3 \\
\text { Nomor } 1 \text { Tahun } \\
2018\end{array}$ \\
\hline & 98 & Jurnal Karinov & 26206161 & $\begin{array}{l}\text { Universitas } \\
\text { Negeri Malang }\end{array}$ & $\begin{array}{l}\text { Usulan Baru } \\
\text { mulai Volume } 1 \\
\text { Nomor } 2 \text { Tahun } \\
2018\end{array}$ \\
\hline & 99 & $\begin{array}{l}\text { Jurnal Kebidanan } \\
\text { dan Kesehatan } \\
\text { Tradisional }\end{array}$ & 25805207 & $\begin{array}{l}\text { Politeknik } \\
\text { Kesehatan } \\
\text { Surakarta }\end{array}$ & $\begin{array}{l}\text { Reakreditasi Naik } \\
\text { Peringkat dari } \\
\text { Peringkat } 6 \text { ke } \\
\text { Peringkat } 4 \text { mulai } \\
\text { Volume } 5 \text { Nomor } \\
1 \text { Tahun } 2020 \\
\end{array}$ \\
\hline
\end{tabular}




\begin{tabular}{|c|c|c|c|c|c|}
\hline \begin{tabular}{|l|} 
Peringkat \\
\end{tabular} & No. & Nama Jurnal & E-ISSN & Penerbit & Keterangan \\
\hline & 100 & $\begin{array}{l}\text { Jurnal Keperawatan } \\
\text { Jiwa }\end{array}$ & 26558106 & $\begin{array}{l}\text { FIKKeS } \\
\text { Universitas } \\
\text { Muhammadiyah } \\
\text { Semarang }\end{array}$ & $\begin{array}{l}\text { Reakreditasi } \\
\text { Tetap di } \\
\text { Peringkat } 4 \text { mulai } \\
\text { Volume } 8 \text { Nomor } \\
1 \text { Tahun } 2020\end{array}$ \\
\hline & 101 & $\begin{array}{l}\text { Jurnal KIBASP } \\
\text { (Kajian Bahasa, } \\
\text { Sastra dan } \\
\text { Pengajaran) }\end{array}$ & 25975218 & $\begin{array}{l}\text { Institut } \\
\text { Penelitian } \\
\text { Matematika, } \\
\text { Komputer, } \\
\text { Keperawatan, } \\
\text { Pendidikan, dan } \\
\text { Ekonomi } \\
\text { (IPM2KPE) } \\
\end{array}$ & $\begin{array}{l}\text { Reakreditasi } \\
\text { Tetap di } \\
\text { Peringkat } 4 \text { mulai } \\
\text { Volume } 3 \text { Nomor } \\
1 \text { Tahun } 2019\end{array}$ \\
\hline & 102 & $\begin{array}{l}\text { Jurnal Kumparan } \\
\text { Fisika }\end{array}$ & 26551403 & $\begin{array}{l}\text { Universitas } \\
\text { Bengkulu }\end{array}$ & $\begin{array}{l}\text { Usulan Baru } \\
\text { mulai Volume } 1 \\
\text { Nomor } 1 \text { Tahun } \\
2018\end{array}$ \\
\hline & 103 & $\begin{array}{l}\text { Jurnal Mutu } \\
\text { Pangan: Indonesian } \\
\text { Journal of Food } \\
\text { Quality }\end{array}$ & 26849550 & $\begin{array}{l}\text { Departemen Ilmu } \\
\text { dan Teknologi } \\
\text { Pangan, Institut } \\
\text { Pertanian Bogor }\end{array}$ & $\begin{array}{l}\text { Usulan Baru } \\
\text { mulai Volume } 5 \\
\text { Nomor } 1 \text { Tahun } \\
2018\end{array}$ \\
\hline & 104 & $\begin{array}{l}\text { Jurnal Pendidikan } \\
\text { Dasar }\end{array}$ & 25495801 & $\begin{array}{l}\text { Program } \\
\text { Pascasarjana, } \\
\text { Universitas } \\
\text { Negeri Jakarta }\end{array}$ & $\begin{array}{l}\text { Usulan Baru } \\
\text { mulai Volume } 9 \\
\text { Nomor } 1 \text { Tahun } \\
2018\end{array}$ \\
\hline & 105 & $\begin{array}{l}\text { Jurnal Pendidikan } \\
\text { Matematika: Judika } \\
\text { Education }\end{array}$ & 26146088 & $\begin{array}{l}\text { Institut } \\
\text { Penelitian } \\
\text { Matematika, } \\
\text { Komputer, } \\
\text { Keperawatan, } \\
\text { Pendidikan dan } \\
\text { Ekonomi } \\
\text { (IPM2KPE) }\end{array}$ & $\begin{array}{l}\text { Usulan Baru } \\
\text { mulai Volume } 1 \\
\text { Nomor } 1 \text { Tahun } \\
2018\end{array}$ \\
\hline & 106 & $\begin{array}{l}\text { Jurnal Pendidikan } \\
\text { Sejarah }\end{array}$ & 25809180 & $\begin{array}{l}\text { LPPM Universitas } \\
\text { Negeri Jakarta }\end{array}$ & $\begin{array}{l}\text { Reakreditasi Naik } \\
\text { Peringkat dari } \\
\text { Peringkat } 6 \text { ke } \\
\text { Peringkat } 4 \text { mulai } \\
\text { Volume } 7 \text { Nomor } \\
2 \text { Tahun } 2018\end{array}$ \\
\hline & 107 & $\begin{array}{l}\text { Jurnal Pendidikan } \\
\text { Sejarah Indonesia }\end{array}$ & 26221837 & $\begin{array}{l}\text { Universitas } \\
\text { Negeri Malang }\end{array}$ & $\begin{array}{l}\text { Usulan Baru } \\
\text { mulai Volume } 1 \\
\text { Nomor } 1 \text { Tahun } \\
2018\end{array}$ \\
\hline & 108 & $\begin{array}{l}\text { Jurnal Penelitian } \\
\text { Humaniora }\end{array}$ & 25414496 & $\begin{array}{l}\text { Lembaga } \\
\text { Penelitian dan } \\
\text { Pengabdian } \\
\text { Masyarakat } \\
\text { Universitas } \\
\text { Muhammadiyah } \\
\text { Surakarta }\end{array}$ & $\begin{array}{l}\text { Reakreditasi Naik } \\
\text { Peringkat dari } \\
\text { Peringkat } 5 \text { ke } \\
\text { Peringkat } 4 \text { mulai } \\
\text { Volume } 21 \\
\text { Nomor } 1 \text { Tahun } \\
20208\end{array}$ \\
\hline
\end{tabular}




\begin{tabular}{|c|c|c|c|c|c|}
\hline Peringkat & No. & Nama Jurnal & E-ISSN & Penerbit & Keterangan \\
\hline & 109 & $\begin{array}{l}\text { Jurnal Penelitian } \\
\text { Transportasi Laut }\end{array}$ & 25484087 & $\begin{array}{l}\text { Puslitbang } \\
\text { Transportasi } \\
\text { Laut, Sungai, } \\
\text { Danau, dan } \\
\text { Penyeberangan }\end{array}$ & $\begin{array}{l}\text { Usulan Baru } \\
\text { mulai Volume } 19 \\
\text { Nomor } 2 \text { Tahun } \\
2017\end{array}$ \\
\hline & 110 & $\begin{array}{l}\text { Jurnal Persatuan } \\
\text { Perawat Nasional } \\
\text { Indonesia (JPPNI) }\end{array}$ & 25498576 & $\begin{array}{l}\text { Dewan Pengurus } \\
\text { Pusat Persatuan } \\
\text { Perawat Nasional } \\
\text { Indonesia }\end{array}$ & $\begin{array}{l}\text { Usulan Baru } \\
\text { mulai Volume } 3 \\
\text { Nomor } 1 \text { Tahun } \\
2018\end{array}$ \\
\hline & 111 & Jurnal Planoearth & 26154226 & $\begin{array}{l}\text { Universitas } \\
\text { Muhammadiyah } \\
\text { Mataram }\end{array}$ & $\begin{array}{l}\text { Usulan Baru } \\
\text { mulai Volume } 3 \\
\text { Nomor } 1 \text { Tahun } \\
2018\end{array}$ \\
\hline & 112 & $\begin{array}{l}\text { Jurnal Ruaya: } \\
\text { Jurnal Penelitian } \\
\text { dan Kajian Ilmu } \\
\text { Perikanan dan } \\
\text { Kelautan }\end{array}$ & 25413155 & $\begin{array}{l}\text { Universitas } \\
\text { Muhammadiyah } \\
\text { Pontianak }\end{array}$ & $\begin{array}{l}\text { Reakreditasi Naik } \\
\text { Peringkat dari } \\
\text { Peringkat } 5 \text { ke } \\
\text { Peringkat } 4 \text { mulai } \\
\text { Volume } 8 \text { Nomor } \\
1 \text { Tahun } 2020\end{array}$ \\
\hline & 113 & $\begin{array}{l}\text { Jurnal Sains dan } \\
\text { Informatika: } \\
\text { Research of Science } \\
\text { and Informatic }\end{array}$ & $2502096 \mathrm{X}$ & $\begin{array}{l}\text { Lembaga } \\
\text { Layanan } \\
\text { Pendidikan } \\
\text { Tinggi Wilayah X }\end{array}$ & $\begin{array}{l}\text { Reakreditasi } \\
\text { Tetap di } \\
\text { Peringkat } 4 \text { mulai } \\
\text { Volume } 5 \text { Nomor } \\
2 \text { Tahun } 2019\end{array}$ \\
\hline & 114 & $\begin{array}{l}\text { Jurnal Sains dan } \\
\text { Teknologi Maritim }\end{array}$ & 26232030 & $\begin{array}{l}\text { Sekolah Tinggi } \\
\text { Maritim dan } \\
\text { Transport "AMNI" } \\
\text { Semarang }\end{array}$ & $\begin{array}{l}\text { Usulan Baru } \\
\text { mulai Volume } 17 \\
\text { Nomor } 2 \text { Tahun } \\
2018\end{array}$ \\
\hline & 115 & Jurnal Seni Tari & 22526714 & $\begin{array}{l}\text { Universitas } \\
\text { Negeri Semarang }\end{array}$ & $\begin{array}{l}\text { Reakreditasi Naik } \\
\text { Peringkat dari } \\
\text { Peringkat } 5 \text { ke } \\
\text { Peringkat } 4 \text { mulai } \\
\text { Volume } 8 \text { Nomor } \\
2 \text { Tahun } 2019 \\
\end{array}$ \\
\hline & 116 & $\begin{array}{l}\text { Jurnal Techno Nusa } \\
\text { Mandiri }\end{array}$ & $2527676 \mathrm{X}$ & $\begin{array}{l}\text { LPPM STMIK } \\
\text { Nusa Mandiri } \\
\text { Jakarta }\end{array}$ & $\begin{array}{l}\text { Reakreditasi } \\
\text { Tetap di } \\
\text { Peringkat } 4 \text { mulai } \\
\text { Volume } 16 \\
\text { Nomor } 2 \text { Tahun } \\
2019\end{array}$ \\
\hline & 117 & Jurnal Teknik & 27157660 & $\begin{array}{l}\text { Universitas } \\
\text { Negeri Gorontalo }\end{array}$ & $\begin{array}{l}\text { Usulan Baru } \\
\text { mulai Volume } 16 \\
\text { Nomor } 1 \text { Tahun } \\
2018\end{array}$ \\
\hline
\end{tabular}




\begin{tabular}{|c|c|c|c|c|c|}
\hline Peringkat & No. & Nama Jurnal & E-ISSN & Penerbit & Keterangan \\
\hline & 118 & Jurnal Ternak & 26846799 & $\begin{array}{l}\text { Fakultas } \\
\text { Peternakan - } \\
\text { Universitas Islam } \\
\text { Lamongan }\end{array}$ & $\begin{array}{l}\text { Reakreditasi Naik } \\
\text { Peringkat dari } \\
\text { Peringkat } 5 \text { ke } \\
\text { Peringkat } 4 \text { mulai } \\
\text { Volume } 10 \\
\text { Nomor } 2 \text { Tahun } \\
2019\end{array}$ \\
\hline & 119 & $\begin{array}{l}\text { Justindo (Jurnal } \\
\text { Sistem dan } \\
\text { Teknologi Informasi } \\
\text { Indonesia) }\end{array}$ & 25415735 & $\begin{array}{l}\text { Universitas } \\
\text { Muhammadiyah } \\
\text { Jember }\end{array}$ & $\begin{array}{l}\text { Usulan Baru } \\
\text { mulai Volume } 3 \\
\text { Nomor } 1 \text { Tahun } \\
2018\end{array}$ \\
\hline & 120 & $\begin{array}{l}\text { Kacanegara Jurnal } \\
\text { Pengabdian pada } \\
\text { Masyarakat }\end{array}$ & 26572338 & $\begin{array}{l}\text { Sekolah Tinggi } \\
\text { Teknologi } \\
\text { Adisutjipto }\end{array}$ & $\begin{array}{l}\text { Usulan Baru } \\
\text { mulai Volume } 1 \\
\text { Nomor } 1 \text { Tahun } \\
2018\end{array}$ \\
\hline & 121 & $\begin{array}{l}\text { KAGANGA: Jurnal } \\
\text { Pendidikan Sejarah } \\
\text { dan Riset Sosial- } \\
\text { Humaniora }\end{array}$ & 25984934 & $\begin{array}{l}\text { Institut } \\
\text { Penelitian } \\
\text { Matematika, } \\
\text { Komputer, } \\
\text { Keperawatan, } \\
\text { Pendidikan dan } \\
\text { Ekonomi } \\
\text { (IPM2KPE) } \\
\end{array}$ & $\begin{array}{l}\text { Usulan Baru } \\
\text { mulai Volume } 1 \\
\text { Nomor } 1 \text { Tahun } \\
2018\end{array}$ \\
\hline & 122 & Kebudayaan & 26858088 & $\begin{array}{l}\text { Kementerian } \\
\text { Pendidikan dan } \\
\text { Kebudayaan }\end{array}$ & $\begin{array}{l}\text { Usulan Baru } \\
\text { mulai Volume } 13 \\
\text { Nomor } 1 \text { Tahun } \\
2018\end{array}$ \\
\hline & 123 & $\begin{array}{l}\text { KESMAS } \\
\text { UWIGAMA: Jurnal } \\
\text { Kesehatan } \\
\text { Masyarakat }\end{array}$ & 24775819 & $\begin{array}{l}\text { Universitas } \\
\text { Widya Gama } \\
\text { Mahakam } \\
\text { Samarinda }\end{array}$ & $\begin{array}{l}\text { Usulan Baru } \\
\text { mulai Volume } 4 \\
\text { Nomor } 1 \text { Tahun } \\
2018\end{array}$ \\
\hline & 124 & $\begin{array}{l}\text { Kiryoku : Jurnal } \\
\text { Studi Kejepangan }\end{array}$ & 25810960 & $\begin{array}{l}\text { Universitas } \\
\text { Diponegoro }\end{array}$ & $\begin{array}{l}\text { Usulan Baru } \\
\text { mulai Volume } 2 \\
\text { Nomor } 1 \text { Tahun } \\
2018\end{array}$ \\
\hline & 125 & $\begin{array}{l}\text { Komputasi: Jurnal } \\
\text { Ilmiah Ilmu } \\
\text { Komputer dan } \\
\text { Matematika }\end{array}$ & 26543990 & $\begin{array}{l}\text { Universitas } \\
\text { Pakuan }\end{array}$ & $\begin{array}{l}\text { Usulan Baru } \\
\text { mulai Volume } 15 \\
\text { Nomor } 2 \text { Tahun } \\
2018\end{array}$ \\
\hline & 126 & Law and Justice & 25498282 & $\begin{array}{l}\text { Fakultas Hukum } \\
\text { Universitas } \\
\text { Muhammadiyah } \\
\text { Surakarta }\end{array}$ & $\begin{array}{l}\text { Reakreditasi Naik } \\
\text { Peringkat dari } \\
\text { Peringkat } 6 \mathrm{ke} \\
\text { Peringkat } 4 \text { mulai } \\
\text { Volume } 4 \text { Nomor } \\
2 \text { Tahun } 2019 \\
\end{array}$ \\
\hline
\end{tabular}




\begin{tabular}{|c|c|c|c|c|c|}
\hline \begin{tabular}{|l|} 
Peringkat \\
\end{tabular} & No. & Nama Jurnal & E-ISSN & Penerbit & Keterangan \\
\hline & 127 & $\begin{array}{l}\text { Lex Librum: Jurnal } \\
\text { Ilmu Hukum }\end{array}$ & 26219867 & $\begin{array}{l}\text { Sekolah Tinggi } \\
\text { Ilmu Hukum } \\
\text { Sumpah Pemuda }\end{array}$ & $\begin{array}{l}\text { Reakreditasi Naik } \\
\text { Peringkat dari } \\
\text { Peringkat } 5 \text { ke } \\
\text { Peringkat } 4 \text { mulai } \\
\text { Volume } 6 \text { Nomor } \\
1 \text { Tahun } 2019\end{array}$ \\
\hline & 128 & $\begin{array}{l}\text { Linguista: Jurnal } \\
\text { Ilmiah Bahasa, } \\
\text { Sastra, dan } \\
\text { Pembelajarannya }\end{array}$ & 25798944 & $\begin{array}{l}\text { Universitas PGRI } \\
\text { Madiun }\end{array}$ & $\begin{array}{l}\text { Usulan Baru } \\
\text { mulai Volume } 2 \\
\text { Nomor } 1 \text { Tahun } \\
2018\end{array}$ \\
\hline & 129 & $\begin{array}{l}\text { Lingusitic, English } \\
\text { Education and Art } \\
\text { (LEEA) Journal }\end{array}$ & 25973819 & $\begin{array}{l}\text { Institut } \\
\text { Penelitian } \\
\text { Matematika, } \\
\text { Komputer, } \\
\text { Keperawatan, } \\
\text { Pendidikan, dan } \\
\text { Ekonomi } \\
\text { (IPM2KPE) } \\
\end{array}$ & $\begin{array}{l}\text { Reakreditasi } \\
\text { Tetap di } \\
\text { Peringkat } 4 \text { mulai } \\
\text { Volume } 3 \text { Nomor } \\
1 \text { Tahun } 2019\end{array}$ \\
\hline & 130 & $\begin{array}{l}\text { Living Islam: Journal } \\
\text { of Islamic } \\
\text { Discourses }\end{array}$ & 26216590 & $\begin{array}{l}\text { Universitas Islam } \\
\text { Negeri Sunan } \\
\text { Kalijaga }\end{array}$ & $\begin{array}{l}\text { Usulan Baru } \\
\text { mulai Volume } 1 \\
\text { Nomor } 2 \text { Tahun } \\
2018\end{array}$ \\
\hline & 131 & $\begin{array}{l}\text { Malahayati } \\
\text { International } \\
\text { Journal of Nursing } \\
\text { and Health Science }\end{array}$ & 26214083 & $\begin{array}{l}\text { Universitas } \\
\text { Malahayati }\end{array}$ & $\begin{array}{l}\text { Usulan Baru } \\
\text { mulai Volume } 1 \\
\text { Nomor } 1 \text { Tahun } \\
2018\end{array}$ \\
\hline & 132 & $\begin{array}{l}\text { Matappa: Jurnal } \\
\text { Pengabdian Kepada } \\
\text { Masyarakat }\end{array}$ & 26146673 & $\begin{array}{l}\text { STKIP Andi } \\
\text { Matappa } \\
\text { Pangkep }\end{array}$ & $\begin{array}{l}\text { Usulan Baru } \\
\text { mulai Volume } 1 \\
\text { Nomor } 1 \text { Tahun } \\
2018\end{array}$ \\
\hline & 133 & $\begin{array}{l}\text { Modeling: Jurnal } \\
\text { Prodi PGMI }\end{array}$ & $2477667 X$ & $\begin{array}{l}\text { Prodi PGMI } \\
\text { STITNU Al } \\
\text { Hikmah } \\
\text { Mojokerto }\end{array}$ & $\begin{array}{l}\text { Reakreditasi } \\
\text { Tetap di } \\
\text { Peringkat } 4 \text { mulai } \\
\text { Volume } 6 \text { Nomor } \\
2 \text { Tahun } 2019\end{array}$ \\
\hline & 134 & $\begin{array}{l}\text { MPI (Media } \\
\text { Pharmaceutica } \\
\text { Indonesiana) }\end{array}$ & 25279017 & $\begin{array}{l}\text { Fakultas Farmasi } \\
\text { Universitas } \\
\text { Surabaya }\end{array}$ & $\begin{array}{l}\text { Reakreditasi } \\
\text { Tetap di } \\
\text { Peringkat } 4 \text { mulai } \\
\text { Volume } 2 \text { Nomor } \\
4 \text { Tahun } 2019\end{array}$ \\
\hline & 135 & $\begin{array}{l}\text { Mulawarman Law } \\
\text { Review }\end{array}$ & 25273477 & $\begin{array}{l}\text { Fakultas Hukum } \\
\text { Universitas } \\
\text { Mulawarman }\end{array}$ & $\begin{array}{l}\text { Usulan Baru } \\
\text { mulai Volume } 3 \\
\text { Nomor } 1 \text { Tahun } \\
2018\end{array}$ \\
\hline & 136 & $\begin{array}{l}\text { Nation State: } \\
\text { Journal of } \\
\text { International Studies } \\
\text { (NSJIS) }\end{array}$ & $2621735 \mathrm{X}$ & $\begin{array}{l}\text { Fakultas } \\
\text { Ekonomi dan } \\
\text { Ilmu Sosial } \\
\text { Universitas } \\
\text { AMIKOM } \\
\text { Yogyakarta } \\
\end{array}$ & $\begin{array}{l}\text { Usulan Baru } \\
\text { mulai Volume } 1 \\
\text { Nomor } 1 \text { Tahun } \\
2018\end{array}$ \\
\hline
\end{tabular}




\begin{tabular}{|c|c|c|c|c|c|}
\hline \begin{tabular}{|l|} 
Peringkat \\
\end{tabular} & No. & Nama Jurnal & E-ISSN & Penerbit & Keterangan \\
\hline & 137 & $\begin{array}{l}\text { Nisbah: Jurnal } \\
\text { Perbankan Syariah }\end{array}$ & 25286633 & $\begin{array}{l}\text { Program Studi } \\
\text { Perbankan } \\
\text { Syariah Fakultas } \\
\text { Ekonomi Islam } \\
\text { Universitas } \\
\text { Djuanda Bogor }\end{array}$ & $\begin{array}{l}\text { Reakreditasi Naik } \\
\text { Peringkat dari } \\
\text { Peringkat } 5 \text { ke } \\
\text { Peringkat } 4 \text { mulai } \\
\text { Volume } 4 \text { Nomor } \\
1 \text { Tahun } 2018\end{array}$ \\
\hline & 138 & $\begin{array}{l}\text { Nun: Jurnal Studi } \\
\text { Alquran dan Tafsir } \\
\text { di Nusantara }\end{array}$ & 25812254 & $\begin{array}{l}\text { Asosiasi Ilmu } \\
\text { Alqur'an dan } \\
\text { Tafsir se- } \\
\text { Indonesia }\end{array}$ & $\begin{array}{l}\text { Usulan Baru } \\
\text { mulai Volume } 4 \\
\text { Nomor } 1 \text { Tahun } \\
2018\end{array}$ \\
\hline & 139 & Paedagogie & 26217171 & $\begin{array}{l}\text { Universitas } \\
\text { Muhammadiyah } \\
\text { Magelang }\end{array}$ & $\begin{array}{l}\text { Usulan Baru } \\
\text { mulai Volume } 13 \\
\text { Nomor } 1 \text { Tahun } \\
2018\end{array}$ \\
\hline & 140 & $\begin{array}{l}\text { PARETO: Jurnal } \\
\text { Ekonomi dan } \\
\text { Kebijakan Publik }\end{array}$ & 26203456 & $\begin{array}{l}\text { Fakultas } \\
\text { Ekonomi } \\
\text { Universitas Prof. } \\
\text { Dr. Hazairin, SH }\end{array}$ & $\begin{array}{l}\text { Usulan Baru } \\
\text { mulai Volume } 1 \\
\text { Nomor } 1 \text { Tahun } \\
2018\end{array}$ \\
\hline & 141 & $\begin{array}{l}\text { Pastura: Journal of } \\
\text { Tropical Forage } \\
\text { Science }\end{array}$ & 25498444 & $\begin{array}{l}\text { Universitas } \\
\text { Udayana }\end{array}$ & $\begin{array}{l}\text { Usulan Baru } \\
\text { mulai Volume } 7 \\
\text { Nomor } 2 \text { Tahun } \\
2018\end{array}$ \\
\hline & 142 & $\begin{array}{l}\text { Pasundan Food } \\
\text { Technology Journal } \\
\text { (PFTJ) }\end{array}$ & 26151405 & $\begin{array}{l}\text { Universitas } \\
\text { Pasundan }\end{array}$ & $\begin{array}{l}\text { Usulan Baru } \\
\text { mulai Volume } 5 \\
\text { Nomor } 1 \text { Tahun } \\
2018\end{array}$ \\
\hline & 143 & $\begin{array}{l}\text { Permana: Jurnal } \\
\text { Perpajakan, } \\
\text { Manajemen, dan } \\
\text { Akuntansi }\end{array}$ & $2685600 X$ & $\begin{array}{l}\text { Universitas } \\
\text { Pancasakti Tegal }\end{array}$ & $\begin{array}{l}\text { Usulan Baru } \\
\text { mulai Volume } 10 \\
\text { Nomor } 1 \text { Tahun } \\
2018\end{array}$ \\
\hline & 144 & $\begin{array}{l}\text { Rabit: Jurnal } \\
\text { Teknologi dan } \\
\text { Sistem Informasi } \\
\text { Univrab }\end{array}$ & $2502891 X$ & $\begin{array}{l}\text { LPPM Universitas } \\
\text { Abdurrab }\end{array}$ & $\begin{array}{l}\text { Reakreditasi Naik } \\
\text { Peringkat dari } \\
\text { Peringkat } 5 \mathrm{ke} \\
\text { Peringkat } 4 \text { mulai } \\
\text { Volume } 5 \text { Nomor } \\
1 \text { Tahun } 2020\end{array}$ \\
\hline & 145 & $\begin{array}{l}\text { Samakia: Jurnal } \\
\text { Ilmu Perikanan }\end{array}$ & 25032283 & $\begin{array}{l}\text { Fakultas Sains \& } \\
\text { Teknologi, } \\
\text { Universitas } \\
\text { Ibrahimy }\end{array}$ & $\begin{array}{l}\text { Reakreditasi Naik } \\
\text { Peringkat dari } \\
\text { Peringkat } 5 \text { ke } \\
\text { Peringkat } 4 \text { mulai } \\
\text { Volume } 9 \text { Nomor } \\
1 \text { Tahun } 2018\end{array}$ \\
\hline & 146 & $\begin{array}{l}\text { SeBaSa: Jurnal } \\
\text { Pendidikan Bahasa } \\
\text { dan Sastra } \\
\text { Indonesia }\end{array}$ & 26210851 & $\begin{array}{l}\text { Universitas } \\
\text { Hamzanwadi }\end{array}$ & $\begin{array}{l}\text { Usulan Baru } \\
\text { mulai Volume } 1 \\
\text { Nomor } 1 \text { Tahun } \\
2018\end{array}$ \\
\hline
\end{tabular}




\begin{tabular}{|c|c|c|c|c|c|}
\hline \begin{tabular}{|l|} 
Peringkat \\
\end{tabular} & No. & Nama Jurnal & E-ISSN & Penerbit & Keterangan \\
\hline & 147 & $\begin{array}{l}\text { Siklus: Journal } \\
\text { Research Midwifery } \\
\text { Politeknik Tegal }\end{array}$ & 25495054 & $\begin{array}{l}\text { Pusat Penelitian } \\
\text { dan Pengabdian } \\
\text { Masyarakat } \\
\text { (P3M) Politeknik } \\
\text { Harapan } \\
\text { Bersama }\end{array}$ & $\begin{array}{l}\text { Reakreditasi } \\
\text { Tetap di } \\
\text { Peringkat } 4 \text { mulai } \\
\text { Volume } 9 \text { Nomor } \\
1 \text { Tahun } 2020\end{array}$ \\
\hline & 148 & Simbiosa & 25986007 & $\begin{array}{l}\text { Universitas Riau } \\
\text { Kepulauan }\end{array}$ & $\begin{array}{l}\text { Reakreditasi } \\
\text { Tetap di } \\
\text { Peringkat } 4 \text { mulai } \\
\text { Volume } 8 \text { Nomor } \\
2 \text { Tahun } 2019\end{array}$ \\
\hline & 149 & Sirok Bastra & 26212013 & $\begin{array}{l}\text { Kantor Bahasa } \\
\text { Kepulauan } \\
\text { Bangka Belitung }\end{array}$ & $\begin{array}{l}\text { Usulan Baru } \\
\text { mulai Volume } 6 \\
\text { Nomor } 2 \text { Tahun } \\
2018\end{array}$ \\
\hline & 150 & $\begin{array}{l}\text { Smart Medical } \\
\text { Journal }\end{array}$ & 2621091 & $\begin{array}{l}\text { Universitas } \\
\text { Sebelas Maret }\end{array}$ & $\begin{array}{l}\text { Usulan Baru } \\
\text { mulai Volume } 1 \\
\text { Nomor } 1 \text { Tahun } \\
2018\end{array}$ \\
\hline & 151 & $\begin{array}{l}\text { Socia: Jurnal Ilmu- } \\
\text { Ilmu Sosial }\end{array}$ & 25499475 & $\begin{array}{l}\text { Fakultas Ilmu } \\
\text { Sosial } \\
\text { Universitas } \\
\text { Negeri } \\
\text { Yogyakarta }\end{array}$ & $\begin{array}{l}\text { Reakreditasi Naik } \\
\text { Peringkat dari } \\
\text { Peringkat } 5 \text { ke } \\
\text { Peringkat } 4 \text { mulai } \\
\text { Volume } 16 \\
\text { Nomor } 2 \text { Tahun } \\
2019\end{array}$ \\
\hline & 152 & $\begin{array}{l}\text { Socius (Pendidikan } \\
\text { dan Pembelajaran } \\
\text { Ilmu Pengetahuan } \\
\text { Sosial) }\end{array}$ & $2089967 X$ & $\begin{array}{l}\text { Universitas } \\
\text { Lambung } \\
\text { Mangkurat }\end{array}$ & $\begin{array}{l}\text { Usulan Baru } \\
\text { mulai Volume } 7 \\
\text { Nomor } 1 \text { Tahun } \\
2018\end{array}$ \\
\hline & 153 & $\begin{array}{l}\text { SPEJ (Science and } \\
\text { Physics Education } \\
\text { Journal) }\end{array}$ & 25982567 & $\begin{array}{l}\text { Institut } \\
\text { Penelitian } \\
\text { Matematika, } \\
\text { Komputer, } \\
\text { Keperawatan, } \\
\text { Pendidikan, dan } \\
\text { Ekonomi } \\
\text { (IPM2KPE) } \\
\end{array}$ & $\begin{array}{l}\text { Reakreditasi } \\
\text { Tetap di } \\
\text { Peringkat } 4 \text { mulai } \\
\text { Volume } 3 \text { Nomor } \\
1 \text { Tahun } 2019\end{array}$ \\
\hline & 154 & $\begin{array}{l}\text { Sutasoma : Jurnal } \\
\text { Sastra Jawa }\end{array}$ & 26865408 & $\begin{array}{l}\text { Jurusan Bahasa } \\
\text { dan Sastra Jawa, } \\
\text { Fakultas Bahasa } \\
\text { dan Seni, } \\
\text { Universitas } \\
\text { Negeri Semarang }\end{array}$ & $\begin{array}{l}\text { Usulan Baru } \\
\text { mulai Volume } 6 \\
\text { Nomor } 1 \text { Tahun } \\
2018\end{array}$ \\
\hline & 155 & $\begin{array}{l}\text { Tekinfo (Jurnal } \\
\text { Ilmiah Teknik } \\
\text { Industri dan } \\
\text { Informasi) }\end{array}$ & 23031867 & $\begin{array}{l}\text { Program Studi S1 } \\
\text { Teknik Industri - } \\
\text { Universitas Setia } \\
\text { Budi }\end{array}$ & $\begin{array}{l}\text { Usulan Baru } \\
\text { mulai Volume } 6 \\
\text { Nomor } 2 \text { Tahun } \\
2018\end{array}$ \\
\hline
\end{tabular}




\begin{tabular}{|c|c|c|c|c|c|}
\hline \begin{tabular}{|l|} 
Peringkat \\
\end{tabular} & No. & Nama Jurnal & E-ISSN & Penerbit & Keterangan \\
\hline & 156 & $\begin{array}{l}\text { Teknika: Jurnal } \\
\text { Sains dan Teknologi }\end{array}$ & 26544113 & $\begin{array}{l}\text { Fakultas Teknik } \\
\text { Universitas } \\
\text { Sultan Ageng } \\
\text { Tirtayasa }\end{array}$ & $\begin{array}{l}\text { Reakreditasi Naik } \\
\text { Peringkat dari } \\
\text { Peringkat } 5 \text { ke } \\
\text { Peringkat } 4 \text { mulai } \\
\text { Volume } 15 \\
\text { Nomor } 2 \text { Tahun } \\
2019\end{array}$ \\
\hline & 157 & Teknodika & 26566621 & $\begin{array}{l}\text { Program Studi } \\
\text { Magister } \\
\text { Teknologi } \\
\text { Pendidikan } \\
\text { Universitas } \\
\text { Sebelas Maret }\end{array}$ & $\begin{array}{l}\text { Usulan Baru } \\
\text { mulai Volume } 16 \\
\text { Nomor } 1 \text { Tahun } \\
2018\end{array}$ \\
\hline & 158 & $\begin{array}{l}\text { The Indonesian } \\
\text { Journal of Health } \\
\text { Science }\end{array}$ & 24769614 & $\begin{array}{l}\text { Universitas } \\
\text { Muhammadiyah } \\
\text { Jember }\end{array}$ & $\begin{array}{l}\text { Reakreditasi Naik } \\
\text { Peringkat dari } \\
\text { Peringkat } 5 \text { ke } \\
\text { Peringkat } 4 \text { mulai } \\
\text { Volume } 10 \\
\text { Nomor } 1 \text { Tahun } \\
2018\end{array}$ \\
\hline & 159 & $\begin{array}{l}\text { The International } \\
\text { Journal of Applied } \\
\text { Business }\end{array}$ & 25990705 & $\begin{array}{l}\text { Universitas } \\
\text { Airlangga }\end{array}$ & $\begin{array}{l}\text { Usulan Baru } \\
\text { mulai Volume } 2 \\
\text { Nomor } 1 \text { Tahun } \\
2018\end{array}$ \\
\hline & 160 & $\begin{array}{l}\text { The International } \\
\text { Journal of Business } \\
\text { Review (The Jobs } \\
\text { Review) }\end{array}$ & $2621413 X$ & $\begin{array}{l}\text { Universitas } \\
\text { Pendidikan } \\
\text { Indonesia }\end{array}$ & $\begin{array}{l}\text { Usulan Baru } \\
\text { mulai Volume } 1 \\
\text { Nomor } 1 \text { Tahun } \\
2018\end{array}$ \\
\hline & 161 & $\begin{array}{l}\text { Tropical Wetland } \\
\text { Journal }\end{array}$ & $2654279 X$ & $\begin{array}{l}\text { Program } \\
\text { Pascasarjana, } \\
\text { Universitas } \\
\text { Lambung } \\
\text { Mangkurat }\end{array}$ & $\begin{array}{l}\text { Usulan Baru } \\
\text { mulai Volume } 4 \\
\text { Nomor } 1 \text { Tahun } \\
2018\end{array}$ \\
\hline & 162 & $\begin{array}{l}\text { Undas: Jurnal Hasil } \\
\text { Penelitian Bahasa } \\
\text { dan Sastra }\end{array}$ & 18584470 & $\begin{array}{l}\text { Balai Bahasa } \\
\text { Kalimantan } \\
\text { Selatan }\end{array}$ & $\begin{array}{l}\text { Usulan Baru } \\
\text { mulai Volume } 14 \\
\text { Nomor } 1 \text { Tahun } \\
2018\end{array}$ \\
\hline & 163 & $\begin{array}{l}\text { Warmadewa } \\
\text { Medical Journal } \\
\text { (WMJ) }\end{array}$ & 25799010 & $\begin{array}{l}\text { Universitas } \\
\text { Warmadewa }\end{array}$ & $\begin{array}{l}\text { Reakreditasi } \\
\text { Tetap di } \\
\text { Peringkat } 4 \text { mulai } \\
\text { Volume } 4 \text { Nomor } \\
3 \text { Tahun } 2019\end{array}$ \\
\hline & 164 & $\begin{array}{l}\text { World Nutrition } \\
\text { Journal }\end{array}$ & 25807013 & $\begin{array}{l}\text { Perhimpunan } \\
\text { Nutrisi Indonesia }\end{array}$ & $\begin{array}{l}\text { Usulan Baru } \\
\text { mulai Volume } 2 \\
\text { Nomor } 1 \text { Tahun } \\
2018\end{array}$ \\
\hline
\end{tabular}




\begin{tabular}{|c|c|c|c|c|c|}
\hline \begin{tabular}{|l|} 
Peringkat \\
\end{tabular} & No. & Nama Jurnal & E-ISSN & Penerbit & Keterangan \\
\hline \multirow[t]{10}{*}{5} & 1 & $\begin{array}{l}\text { Agro Bali: } \\
\text { Agricultural Journal }\end{array}$ & $2655853 X$ & $\begin{array}{l}\text { Universitas Panji } \\
\text { Sakti }\end{array}$ & $\begin{array}{l}\text { Usulan Baru } \\
\text { mulai Volume } 1 \\
\text { Nomor } 1 \text { Tahun } \\
2018\end{array}$ \\
\hline & 2 & $\begin{array}{l}\text { Agroekoteknologi } \\
\text { Tropika Lembab }\end{array}$ & $2621394 X$ & $\begin{array}{l}\text { Jurusan } \\
\text { Agroekoteknologi } \\
\text { Fakultas } \\
\text { Pertanian } \\
\text { Universitas } \\
\text { Mulawarman }\end{array}$ & $\begin{array}{l}\text { Usulan Baru } \\
\text { mulai Volume } 1 \\
\text { Nomor } 1 \text { Tahun } \\
2018\end{array}$ \\
\hline & 3 & $\begin{array}{l}\text { Agroindustrial } \\
\text { Technology Journal }\end{array}$ & 25989480 & $\begin{array}{l}\text { Universitas } \\
\text { Darussalam } \\
\text { Gontor }\end{array}$ & $\begin{array}{l}\text { Usulan Baru } \\
\text { mulai Volume } 2 \\
\text { Nomor } 1 \text { Tahun } \\
2018\end{array}$ \\
\hline & 4 & $\begin{array}{l}\text { Al Qodiri: Jurnal } \\
\text { Pendidikan, Sosial } \\
\text { dan Keagamaan }\end{array}$ & 25988735 & $\begin{array}{l}\text { P3M Sekolah } \\
\text { Tinggi Agama } \\
\text { Islam STAI Al- } \\
\text { Qodiri }\end{array}$ & $\begin{array}{l}\text { Reakreditasi Naik } \\
\text { Peringkat dari } \\
\text { Peringkat } 6 \text { ke } \\
\text { Peringkat } 5 \text { mulai } \\
\text { Volume } 17 \\
\text { Nomor } 2 \text { Tahun } \\
2019\end{array}$ \\
\hline & 5 & $\begin{array}{l}\text { Al-Bayan: Jurnal } \\
\text { Ilmu Al-Qur'an dan } \\
\text { Hadist }\end{array}$ & 26152568 & $\begin{array}{l}\text { Sekolah Tinggi } \\
\text { Ilmu Al-Qur'an } \\
\text { Wali Songo } \\
\text { Situbondo }\end{array}$ & $\begin{array}{l}\text { Usulan Baru } \\
\text { mulai Volume } 1 \\
\text { Nomor } 1 \text { Tahun } \\
2018\end{array}$ \\
\hline & 6 & $\begin{array}{l}\text { Al-Fikr: Jurnal } \\
\text { Pendidikan Islam }\end{array}$ & 27163717 & $\begin{array}{l}\text { Sekolah Tinggi } \\
\text { Agama Islam } \\
\text { Negeri Sorong }\end{array}$ & $\begin{array}{l}\text { Usulan Baru } \\
\text { mulai Volume } 4 \\
\text { Nomor } 1 \text { Tahun } \\
2018\end{array}$ \\
\hline & 7 & $\begin{array}{l}\text { Al-Idaroh: Jurnal } \\
\text { Studi Manajemen } \\
\text { Pendidikan Islam }\end{array}$ & 25793683 & $\begin{array}{l}\text { LP3M Sekolah } \\
\text { Tinggi Ilmu } \\
\text { Tarbiyah Al- } \\
\text { Urwatul Wutsqo } \\
\text { Jombang } \\
\end{array}$ & $\begin{array}{l}\text { Usulan Baru } \\
\text { mulai Volume } 2 \\
\text { Nomor } 1 \text { Tahun } \\
2018\end{array}$ \\
\hline & 8 & $\begin{array}{l}\text { Al-Iktisab: Journal } \\
\text { of Islamic Economic } \\
\text { Law }\end{array}$ & $2615661 X$ & $\begin{array}{l}\text { Universitas } \\
\text { Darussalam } \\
\text { Gontor }\end{array}$ & $\begin{array}{l}\text { Usulan Baru } \\
\text { mulai Volume } 2 \\
\text { Nomor } 1 \text { Tahun } \\
2018\end{array}$ \\
\hline & $\overline{9}$ & Al-Mabsut & $2502213 \mathrm{X}$ & $\begin{array}{l}\text { Institut Agama } \\
\text { Islam Ngawi }\end{array}$ & $\begin{array}{l}\text { Usulan Baru } \\
\text { mulai Volume } 12 \\
\text { Nomor } 1 \text { Tahun } \\
2018\end{array}$ \\
\hline & 10 & $\begin{array}{l}\text { Al-Manar: Jurnal } \\
\text { Komunikasi dan } \\
\text { Pendidikan Islam }\end{array}$ & 26158779 & $\begin{array}{l}\text { Sekolah Tinggi } \\
\text { Agama Islam } \\
\text { Masjid Syuhada } \\
\text { (STAIMS) } \\
\text { Yogyakarta }\end{array}$ & $\begin{array}{l}\text { Usulan Baru } \\
\text { mulai Volume } 7 \\
\text { Nomor } 1 \text { Tahun } \\
2018\end{array}$ \\
\hline
\end{tabular}




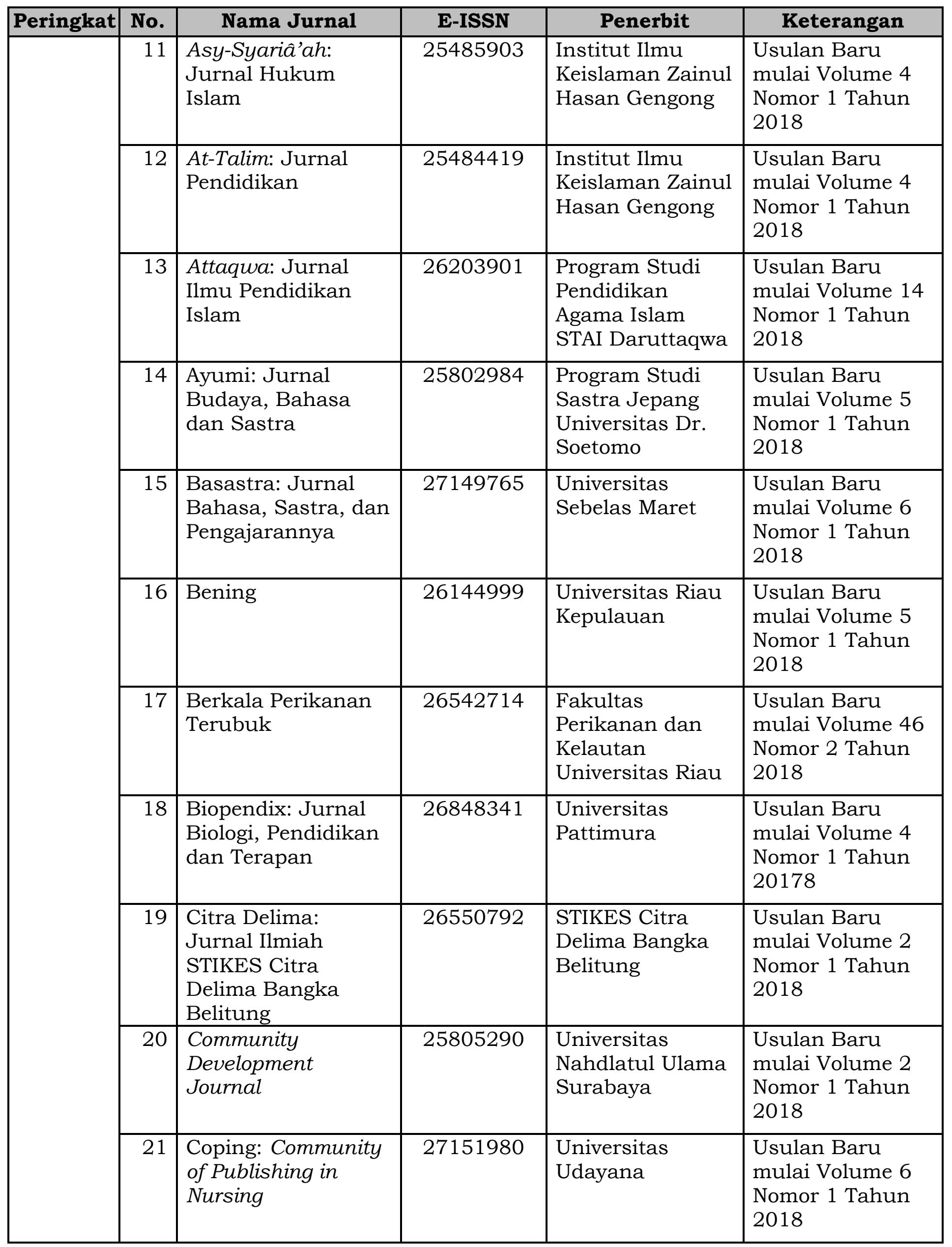




\begin{tabular}{|c|c|c|c|c|c|}
\hline Peringkat & No. & Nama Jurnal & E-ISSN & Penerbit & Keterangan \\
\hline & 22 & $\begin{array}{l}\text { Cyber Security dan } \\
\text { Forensik Digital } \\
\text { (CSFD) }\end{array}$ & 26158442 & $\begin{array}{l}\text { Universitas Islam } \\
\text { Negeri Sunan } \\
\text { Kalijaga }\end{array}$ & $\begin{array}{l}\text { Usulan Baru } \\
\text { mulai Volume } 1 \\
\text { Nomor } 1 \text { Tahun } \\
2018\end{array}$ \\
\hline & 23 & DIALEKTIKA & $2685791 X$ & $\begin{array}{l}\text { Institut Agama } \\
\text { Islam Negeri } \\
\text { Ambon }\end{array}$ & $\begin{array}{l}\text { Usulan Baru } \\
\text { mulai Volume } 11 \\
\text { Nomor } 1 \text { Tahun } \\
2018\end{array}$ \\
\hline & 24 & $\begin{array}{l}\text { Dialektika: Jurnal } \\
\text { Ekonomi dan Ilmu } \\
\text { Sosial }\end{array}$ & $2598781 X$ & $\begin{array}{l}\text { Universitas Islam } \\
\text { Raden Rahmat } \\
\text { Malang }\end{array}$ & $\begin{array}{l}\text { Usulan Baru } \\
\text { mulai Volume } 3 \\
\text { Nomor } 1 \text { Tahun } \\
2018\end{array}$ \\
\hline & 25 & $\begin{array}{l}\text { Didaktika: Jurnal } \\
\text { Pendidikan Sekolah } \\
\text { Dasar }\end{array}$ & 27158128 & $\begin{array}{l}\text { Universitas } \\
\text { Negeri } \\
\text { Yogyakarta }\end{array}$ & $\begin{array}{l}\text { Usulan Baru } \\
\text { mulai Volume } 1 \\
\text { Nomor } 1 \text { Tahun } \\
2018\end{array}$ \\
\hline & 26 & $\begin{array}{l}\text { DIKDAS MATAPPA: } \\
\text { Jurnal Pendidikan } \\
\text { Dasar }\end{array}$ & 26206307 & $\begin{array}{l}\text { STKIP Andi } \\
\text { Matappa } \\
\text { Pangkep }\end{array}$ & $\begin{array}{l}\text { Usulan Baru } \\
\text { mulai Volume } 1 \\
\text { Nomor } 1 \text { Tahun } \\
2018\end{array}$ \\
\hline & 27 & Jurnal Dimensi & 25990004 & $\begin{array}{l}\text { Universitas Riau } \\
\text { Kepulauan } \\
\text { Batam }\end{array}$ & $\begin{array}{l}\text { Usulan Baru } \\
\text { mulai Volume } 7 \\
\text { Nomor } 1 \text { Tahun } \\
2018\end{array}$ \\
\hline & 28 & $\begin{array}{l}\text { Dinamika Global: } \\
\text { Jurnal Ilmu } \\
\text { Hubungan } \\
\text { Internasional }\end{array}$ & 26849399 & $\begin{array}{l}\text { Universitas } \\
\text { Jenderal Achmad } \\
\text { Yani }\end{array}$ & $\begin{array}{l}\text { Usulan Baru } \\
\text { mulai Volume } 3 \\
\text { Nomor } 1 \text { Tahun } \\
2018\end{array}$ \\
\hline & 29 & $\begin{array}{l}\text { E-Bisnis: Jurnal } \\
\text { Ilmiah Ekonomi dan } \\
\text { Bisnis }\end{array}$ & 26148870 & $\begin{array}{l}\text { Sekolah Tinggi } \\
\text { Elektronika dan } \\
\text { Komputer }\end{array}$ & $\begin{array}{l}\text { Usulan Baru } \\
\text { mulai Volume } 11 \\
\text { Nomor } 1 \text { Tahun } \\
2018\end{array}$ \\
\hline & 30 & $\begin{array}{l}\text { Economos: Jurnal } \\
\text { Ekonomi dan Bisnis }\end{array}$ & $2655321 X$ & $\begin{array}{l}\text { Universitas } \\
\text { Muhammadiyah } \\
\text { Parepare }\end{array}$ & $\begin{array}{l}\text { Usulan Baru } \\
\text { mulai Volume } 1 \\
\text { Nomor } 2 \text { Tahun } \\
2018\end{array}$ \\
\hline & 31 & $\begin{array}{l}\text { Edugama: Jurnal } \\
\text { Kependidikan dan } \\
\text { Sosial Keagamaan }\end{array}$ & 26140217 & $\begin{array}{l}\text { LP2M IAIN } \\
\text { Syaikh } \\
\text { Abdurrahman } \\
\text { Siddik Bangka } \\
\text { Belitung }\end{array}$ & $\begin{array}{l}\text { Usulan Baru } \\
\text { mulai Volume } 4 \\
\text { Nomor } 1 \text { Tahun } \\
2018\end{array}$ \\
\hline & 32 & $\begin{array}{l}\text { Efficient: Indonesian } \\
\text { Journal of } \\
\text { Development } \\
\text { Economics }\end{array}$ & $2655318 X$ & $\begin{array}{l}\text { Universitas } \\
\text { Negeri Semarang }\end{array}$ & $\begin{array}{l}\text { Usulan Baru } \\
\text { mulai Volume } 1 \\
\text { Nomor } 2 \text { Tahun } \\
2018\end{array}$ \\
\hline
\end{tabular}




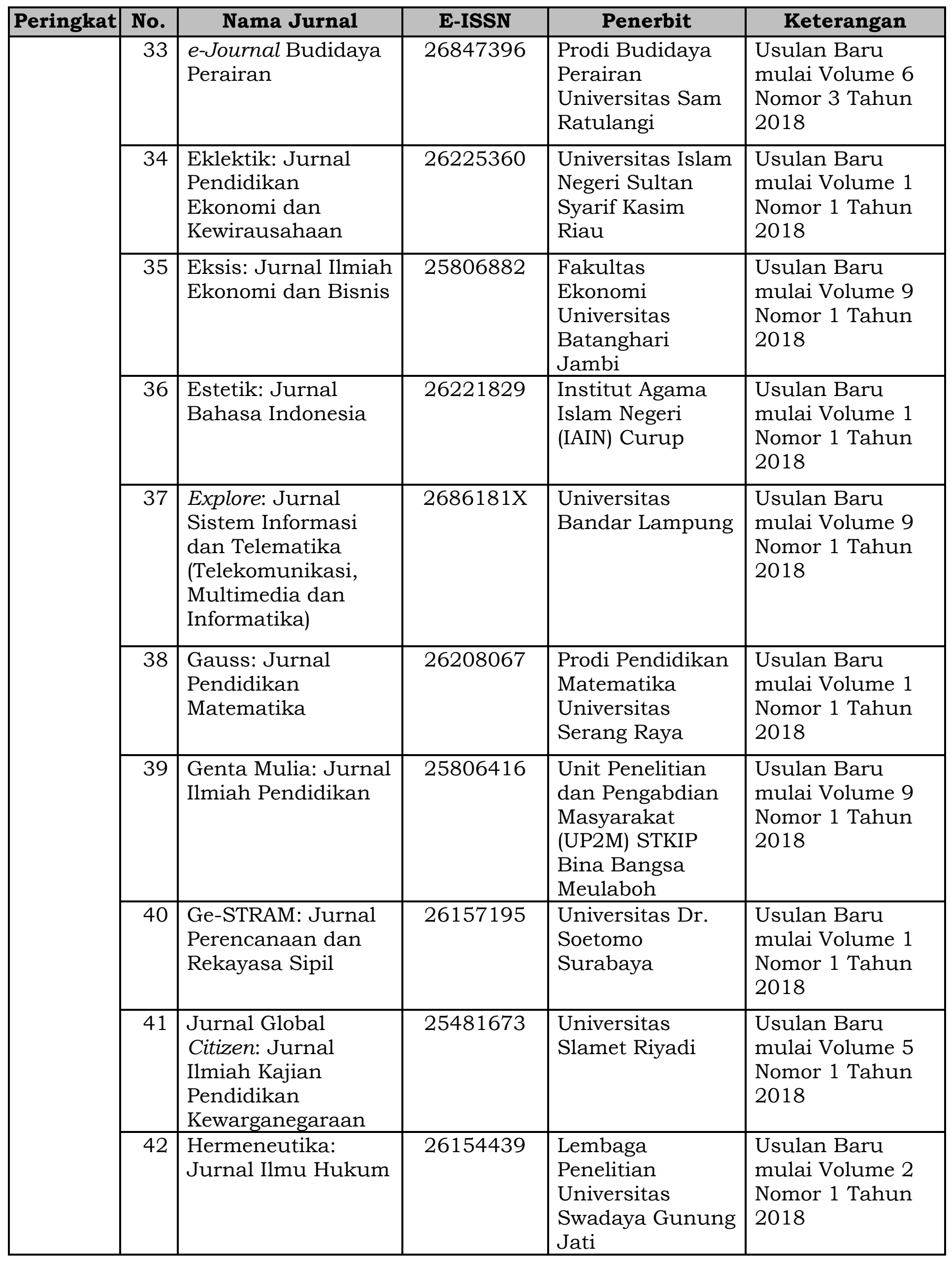

43. Humanika ... 


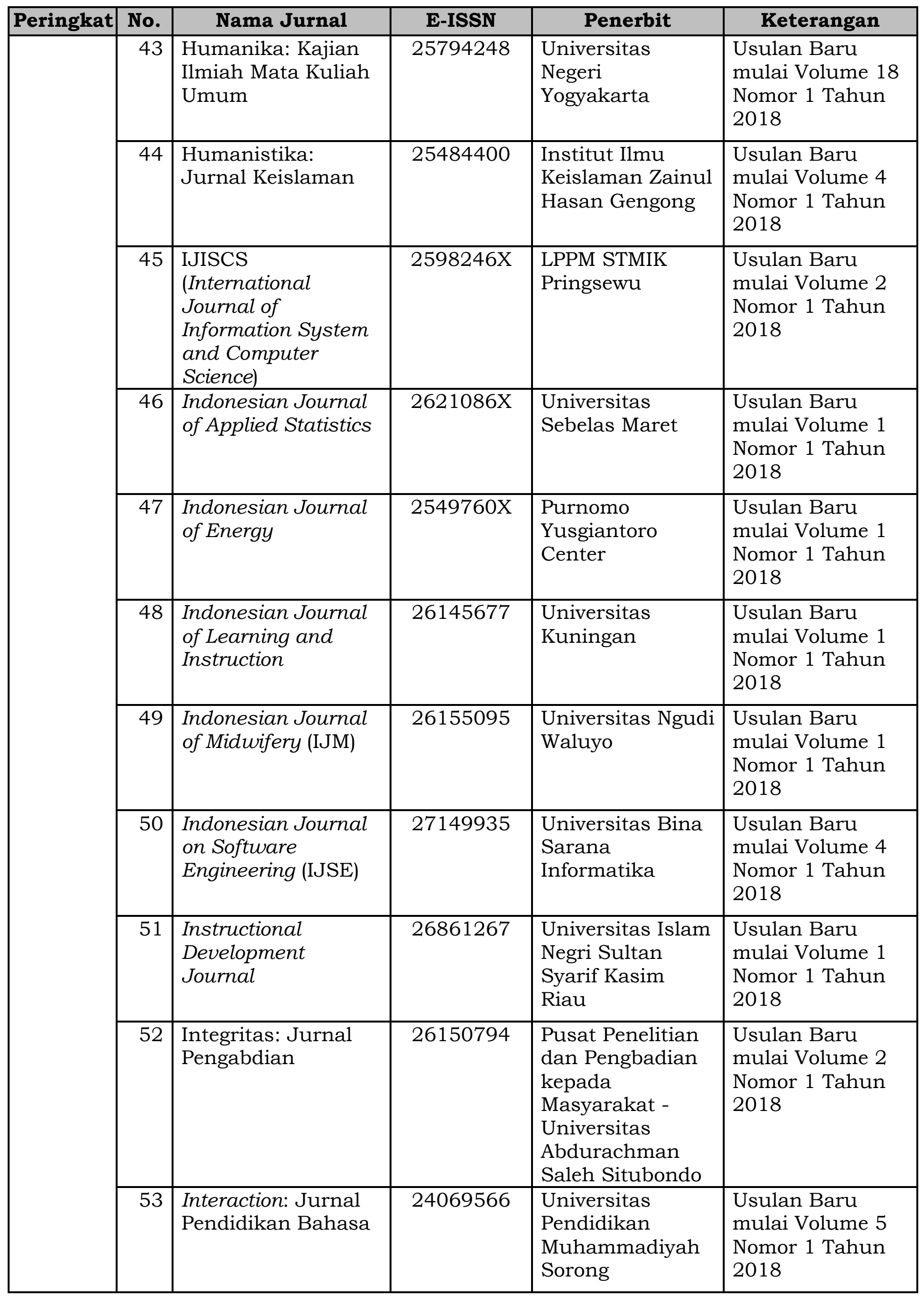

54. Internal ... 


\begin{tabular}{|c|c|c|c|c|c|}
\hline \begin{tabular}{|l|} 
Peringkat \\
\end{tabular} & No. & Nama Jurnal & E-ISSN & Penerbit & Keterangan \\
\hline & 54 & $\begin{array}{l}\text { Internal (Information } \\
\text { System Journal) }\end{array}$ & 26560259 & $\begin{array}{l}\text { Universitas } \\
\text { Masoem }\end{array}$ & $\begin{array}{l}\text { Usulan Baru } \\
\text { mulai Volume } 1 \\
\text { Nomor } 1 \text { Tahun } \\
2018\end{array}$ \\
\hline & 55 & $\begin{array}{l}\text { International } \\
\text { Journal on } \\
\text { Language, Research } \\
\text { and Education } \\
\text { Studies } \\
\end{array}$ & 25806785 & $\begin{array}{l}\text { Fakultas Ilmu } \\
\text { Tarbiyah dan } \\
\text { Keguruan UIN } \\
\text { Sumatera Utara }\end{array}$ & $\begin{array}{l}\text { Usulan Baru } \\
\text { mulai Volume } 2 \\
\text { Nomor } 1 \text { Tahun } \\
2018\end{array}$ \\
\hline & 56 & $\begin{array}{l}\text { IQRO: Journal of } \\
\text { Islamic Education }\end{array}$ & 26223201 & $\begin{array}{l}\text { Prodi Pendidikan } \\
\text { Agama Islam } \\
\text { Institut Agama } \\
\text { Islam Negeri } \\
\text { Palopo } \\
\end{array}$ & $\begin{array}{l}\text { Usulan Baru } \\
\text { mulai Volume } 1 \\
\text { Nomor } 1 \text { Tahun } \\
2018\end{array}$ \\
\hline & 57 & Iqtishodiyah & 25485911 & $\begin{array}{l}\text { Institut Ilmu } \\
\text { Keislaman Zainul } \\
\text { Hasan Gengong }\end{array}$ & $\begin{array}{l}\text { Usulan Baru } \\
\text { mulai Volume } 4 \\
\text { Nomor } 1 \text { Tahun } \\
2018\end{array}$ \\
\hline & 58 & $\begin{array}{l}\text { Islam Transformatif: } \\
\text { Journal of Islamic } \\
\text { Studies }\end{array}$ & 25992171 & $\begin{array}{l}\text { Institut Agama } \\
\text { Islam Negeri } \\
\text { Bukittinggi }\end{array}$ & $\begin{array}{l}\text { Usulan Baru } \\
\text { mulai Volume } 2 \\
\text { Nomor } 1 \text { Tahun } \\
2018\end{array}$ \\
\hline & 59 & $\begin{array}{l}\text { Istighna: Jurnal } \\
\text { Pendidikan dan } \\
\text { Pemikiran Islam }\end{array}$ & 26558459 & $\begin{array}{l}\text { Sekolah Tinggi } \\
\text { ilmu Tarbiyah } \\
\text { Islamic Village }\end{array}$ & $\begin{array}{l}\text { Usulan Baru } \\
\text { mulai Volume } 1 \\
\text { Nomor } 2 \text { Tahun } \\
2018\end{array}$ \\
\hline & 60 & $\begin{array}{l}\text { JAF- Journal of } \\
\text { Accounting and } \\
\text { Finance }\end{array}$ & 25811088 & $\begin{array}{l}\text { Universitas } \\
\text { Telkom }\end{array}$ & $\begin{array}{l}\text { Usulan Baru } \\
\text { mulai Volume } 2 \\
\text { Nomor } 1 \text { Tahun } \\
2018\end{array}$ \\
\hline & 61 & $\begin{array}{l}\text { JAS (Jurnal Agri } \\
\text { Sains) }\end{array}$ & 25810227 & $\begin{array}{l}\text { Universitas } \\
\text { Muara Bungo }\end{array}$ & $\begin{array}{l}\text { Usulan Baru } \\
\text { mulai Volume } 2 \\
\text { Nomor } 1 \text { Tahun } \\
2018\end{array}$ \\
\hline & 62 & $\begin{array}{l}\text { JATI EMAS (Jurnal } \\
\text { Aplikasi Teknik dan } \\
\text { Pengabdian } \\
\text { Masyarakat) }\end{array}$ & 25500821 & $\begin{array}{l}\text { DPD Jawa Timur } \\
\text { Forum Dosen } \\
\text { Indonesia }\end{array}$ & $\begin{array}{l}\text { Usulan Baru } \\
\text { mulai Volume } 2 \\
\text { Nomor } 1 \text { Tahun } \\
2018\end{array}$ \\
\hline & 63 & $\begin{array}{l}\text { JEEMECS (Journal } \\
\text { of Electrical } \\
\text { Engineering, } \\
\text { Mechatronic and } \\
\text { Computer Science) } \\
\end{array}$ & 26144867 & $\begin{array}{l}\text { Universitas } \\
\text { Merdeka Malang }\end{array}$ & $\begin{array}{l}\text { Usulan Baru } \\
\text { mulai Volume } 1 \\
\text { Nomor } 1 \text { Tahun } \\
2018\end{array}$ \\
\hline & 64 & $\begin{array}{l}\text { JIMEK: Jurnal } \\
\text { Ilmiah Mahasiswa } \\
\text { Ekonomi }\end{array}$ & 26212374 & $\begin{array}{l}\text { Fakultas } \\
\text { Ekonomi } \\
\text { Universitas } \\
\text { Kadiri }\end{array}$ & $\begin{array}{l}\text { Usulan Baru } \\
\text { mulai Volume } 1 \\
\text { Nomor } 1 \text { Tahun } \\
2018\end{array}$ \\
\hline
\end{tabular}

65. JISAMAR ... 


\begin{tabular}{|c|c|c|c|c|c|}
\hline Peringkat & No. & Nama Jurnal & E-ISSN & Penerbit & Keterangan \\
\hline & 65 & $\begin{array}{l}\text { JISAMAR (Journal of } \\
\text { Information System, } \\
\text { Applied, } \\
\text { Management, } \\
\text { Accounting and } \\
\text { Research) }\end{array}$ & 25988719 & $\begin{array}{l}\text { Sekolah Tinggi } \\
\text { Manajemen } \\
\text { Informatika dan } \\
\text { Komputer } \\
\text { Jayakarta }\end{array}$ & $\begin{array}{l}\text { Usulan Baru } \\
\text { mulai Volume } 2 \\
\text { Nomor } 1 \text { Tahun } \\
2018\end{array}$ \\
\hline & 66 & $\begin{array}{l}\text { JISIP (Jurnal Ilmu } \\
\text { Sosial dan } \\
\text { Pendidikan) }\end{array}$ & 26566753 & $\begin{array}{l}\text { Lembaga } \\
\text { Penelitian dan } \\
\text { Pendidikan (LPP) } \\
\text { Mandala }\end{array}$ & $\begin{array}{l}\text { Usulan Baru } \\
\text { mulai Volume } 2 \\
\text { Nomor } 1 \text { Tahun } \\
2018\end{array}$ \\
\hline & 67 & $\begin{array}{l}\text { Joined Journal } \\
\text { (Journal of } \\
\text { Informatics } \\
\text { Education) }\end{array}$ & 26208415 & Universitas IVET & $\begin{array}{l}\text { Usulan Baru } \\
\text { mulai Volume } 1 \\
\text { Nomor } 2 \text { Tahun } \\
2018\end{array}$ \\
\hline & 68 & $\begin{array}{l}\text { JOLLT: Journal of } \\
\text { Languages and } \\
\text { Language Teaching' }\end{array}$ & 26211378 & IKIP Mataram & $\begin{array}{l}\text { Reakreditasi } \\
\text { Tetap di } \\
\text { Peringkat } 5 \text { mulai } \\
\text { Volume } 8 \text { Nomor } \\
1 \text { Tahun } 2020 \\
\end{array}$ \\
\hline & 69 & $\begin{array}{l}\text { Journal Civics and } \\
\text { Social Studies }\end{array}$ & 26558963 & $\begin{array}{l}\text { Institut } \\
\text { Pendidikan } \\
\text { Indonesia }\end{array}$ & $\begin{array}{l}\text { Usulan Baru } \\
\text { mulai Volume } 2 \\
\text { Nomor } 1 \text { Tahun } \\
2018\end{array}$ \\
\hline & 70 & $\begin{array}{l}\text { Journal of Applied } \\
\text { Sciences in Travel } \\
\text { and Hospitality }\end{array}$ & 26228319 & $\begin{array}{l}\text { Politeknik Negeri } \\
\text { Bali }\end{array}$ & $\begin{array}{l}\text { Usulan Baru } \\
\text { mulai Volume } 1 \\
\text { Nomor } 3 \text { Tahun } \\
2018\end{array}$ \\
\hline & 71 & $\begin{array}{l}\text { Journal of Music } \\
\text { Science, Technology, } \\
\text { and Industry } \\
\text { (JOMSTI) }\end{array}$ & 26228211 & $\begin{array}{l}\text { Institut Seni } \\
\text { Indonesia } \\
\text { Denpasar }\end{array}$ & $\begin{array}{l}\text { Usulan Baru } \\
\text { mulai Volume } 1 \\
\text { Nomor } 1 \text { Tahun } \\
2018\end{array}$ \\
\hline & 72 & $\begin{array}{l}\text { Journal of } \\
\text { Pharmacopolium }\end{array}$ & 26211521 & $\begin{array}{l}\text { STIKes Bakti } \\
\text { Tunas Husada }\end{array}$ & $\begin{array}{l}\text { Usulan Baru } \\
\text { mulai Volume } 1 \\
\text { Nomor } 1 \text { Tahun } \\
2018\end{array}$ \\
\hline & 73 & $\begin{array}{l}\text { Journal of Science } \\
\text { Education and } \\
\text { Practice }\end{array}$ & 25497170 & $\begin{array}{l}\text { Universitas } \\
\text { Pakuan }\end{array}$ & $\begin{array}{l}\text { Usulan Baru } \\
\text { mulai Volume } 2 \\
\text { Nomor } 1 \text { Tahun } \\
2018\end{array}$ \\
\hline & 74 & J-Proteksion & 25413562 & $\begin{array}{l}\text { Universitas } \\
\text { Muhammadiyah } \\
\text { Jember }\end{array}$ & $\begin{array}{l}\text { Usulan Baru } \\
\text { mulai Volume } 2 \\
\text { Nomor } 2 \text { Tahun } \\
2018\end{array}$ \\
\hline & 75 & $\begin{array}{l}\text { Jurnal Abdiel: } \\
\text { Khazanah } \\
\text { Pemikiran Teologi, } \\
\text { Pendidikan Agama } \\
\text { Kristen, dan Musik } \\
\text { Gereja }\end{array}$ & 26851253 & $\begin{array}{l}\text { Sekolah Tinggi } \\
\text { Theologia Abdiel }\end{array}$ & $\begin{array}{l}\text { Usulan Baru } \\
\text { mulai Volume } 2 \\
\text { Nomor } 1 \text { Tahun } \\
2018\end{array}$ \\
\hline
\end{tabular}




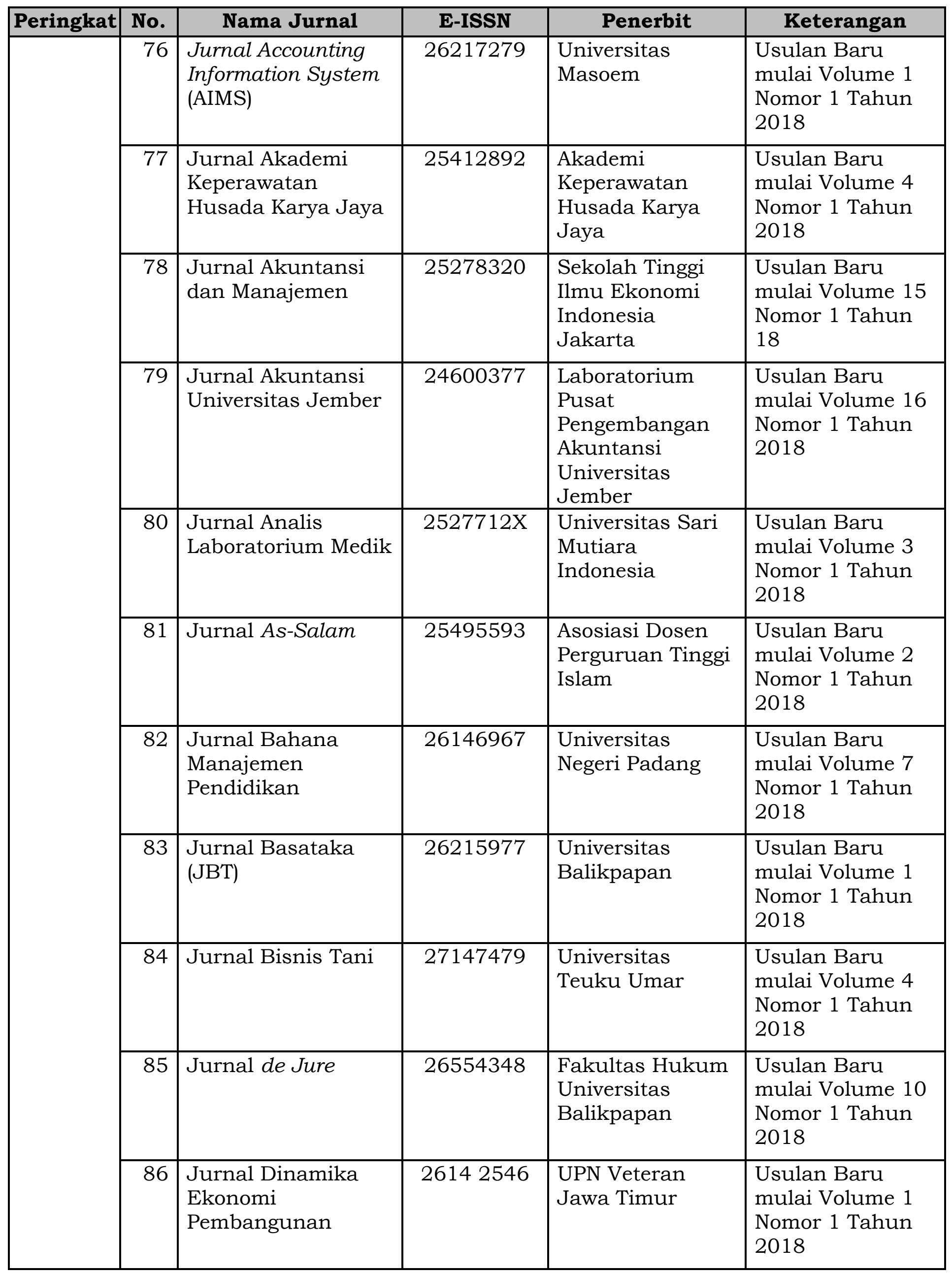




\begin{tabular}{|c|c|c|c|c|c|}
\hline Peringkat & No. & Nama Jurnal & E-ISSN & Penerbit & Keterangan \\
\hline & 87 & Jurnal Doppler & 25803123 & $\begin{array}{l}\text { Prodi Kebidanan } \\
\text { Universitas } \\
\text { Pahlawan } \\
\text { Tuanku } \\
\text { Tambusai } \\
\end{array}$ & $\begin{array}{l}\text { Usulan Baru } \\
\text { mulai Volume } 2 \\
\text { Nomor } 1 \text { Tahun } \\
2018\end{array}$ \\
\hline & 88 & $\begin{array}{l}\text { Jurnal Dunia } \\
\text { Kesmas }\end{array}$ & 25493485 & $\begin{array}{l}\text { Persatuan Dosen } \\
\text { Kesehatan } \\
\text { Masyarakat }\end{array}$ & $\begin{array}{l}\text { Reakreditasi } \\
\text { Tetap di } \\
\text { Peringkat } 5 \text { mulai } \\
\text { Volume } 8 \text { Nomor } \\
4 \text { Tahun } 2019\end{array}$ \\
\hline & 89 & $\begin{array}{l}\text { Jurnal Educatio } \\
\text { FKIP UNMA }\end{array}$ & 25486756 & $\begin{array}{l}\text { Universitas } \\
\text { Majalengka }\end{array}$ & $\begin{array}{l}\text { Usulan Baru } \\
\text { mulai Volume } 4 \\
\text { Nomor } 1 \text { Tahun } \\
2018\end{array}$ \\
\hline & 90 & Jurnal Edueco & 26217511 & $\begin{array}{l}\text { Universitas } \\
\text { Balikpapan }\end{array}$ & $\begin{array}{l}\text { Usulan Baru } \\
\text { mulai Volume } 1 \\
\text { Nomor } 1 \text { Tahun } \\
2018\end{array}$ \\
\hline & 91 & $\begin{array}{l}\text { Jurnal Forum } \\
\text { Mekanika }\end{array}$ & 26558211 & $\begin{array}{l}\text { Sekolah Tinggi } \\
\text { Teknik PLN }\end{array}$ & $\begin{array}{l}\text { Usulan Baru } \\
\text { mulai Volume } 7 \\
\text { Nomor } 1 \text { Tahun } \\
2018\end{array}$ \\
\hline & 92 & Jurnal GeoEkonomi & 25034790 & $\begin{array}{l}\text { Universitas } \\
\text { Balikpapan }\end{array}$ & $\begin{array}{l}\text { Usulan Baru } \\
\text { mulai Volume } 9 \\
\text { Nomor } 1 \text { Tahun } \\
2018\end{array}$ \\
\hline & 93 & $\begin{array}{l}\text { Jurnal Gizi dan } \\
\text { Kesehatan }\end{array}$ & 25803751 & $\begin{array}{l}\text { Program Studi } \\
\text { Gizi Fakultas } \\
\text { Ilmu Kesehatan } \\
\text { Universitas Ngudi } \\
\text { Waluyo }\end{array}$ & $\begin{array}{l}\text { Usulan Baru } \\
\text { mulai Volume } 10 \\
\text { Nomor } 24 \text { Tahun } \\
2018\end{array}$ \\
\hline & 94 & $\begin{array}{l}\text { Jurnal Harpodon } \\
\text { Borneo }\end{array}$ & 25416294 & $\begin{array}{l}\text { Fakultas } \\
\text { Perikanan } \\
\text { Universitas } \\
\text { Borneo Tarakan }\end{array}$ & $\begin{array}{l}\text { Usulan Baru } \\
\text { mulai Volume } 10 \\
\text { Nomor } 2 \text { Tahun } \\
2017\end{array}$ \\
\hline & 95 & $\begin{array}{l}\text { Jurnal IKA PGSD: } \\
\text { Ikatan Alumni } \\
\text { PGSD UNARS }\end{array}$ & 26564459 & $\begin{array}{l}\text { Fakultas } \\
\text { Keguruan dan } \\
\text { Ilmu Pendidikan } \\
\text { Universitas } \\
\text { Abdurachman } \\
\text { Saleh Situbondo }\end{array}$ & $\begin{array}{l}\text { Usulan Baru } \\
\text { mulai Volume } 6 \\
\text { Nomor } 1 \text { Tahun } \\
2018\end{array}$ \\
\hline & 96 & $\begin{array}{l}\text { Jurnal Ilmiah } \\
\text { Betrik: Besemah } \\
\text { Teknologi Informasi } \\
\text { dan Komputer }\end{array}$ & 27157369 & $\begin{array}{l}\text { Sekolah Tinggi } \\
\text { Teknologi Pagar } \\
\text { Alam }\end{array}$ & $\begin{array}{l}\text { Usulan Baru } \\
\text { mulai Volume } 9 \\
\text { Nomor } 1 \text { Tahun } \\
2018\end{array}$ \\
\hline & 97 & $\begin{array}{l}\text { Jurnal Ilmiah } \\
\text { Informatika } \\
\text { Komputer }\end{array}$ & 20898045 & $\begin{array}{l}\text { Universitas } \\
\text { Gunadarma }\end{array}$ & $\begin{array}{l}\text { Usulan Baru } \\
\text { mulai Volume } 23 \\
\text { Nomor } 1 \text { Tahun } \\
2018\end{array}$ \\
\hline
\end{tabular}




\begin{tabular}{|c|c|c|c|c|c|}
\hline \begin{tabular}{|l|} 
Peringkat \\
\end{tabular} & No. & Nama Jurnal & E-ISSN & Penerbit & Keterangan \\
\hline & 98 & $\begin{array}{l}\text { Jurnal Ilmiah } \\
\text { Keperawatan Imelda }\end{array}$ & 25977172 & $\begin{array}{l}\text { Universitas } \\
\text { Imelda Medan }\end{array}$ & $\begin{array}{l}\text { Usulan Baru } \\
\text { mulai Volume } 4 \\
\text { Nomor } 1 \text { Tahun } \\
2018\end{array}$ \\
\hline & 99 & $\begin{array}{l}\text { Jurnal Ilmiah } \\
\text { Pangabdhi }\end{array}$ & 24776289 & $\begin{array}{l}\text { Universitas } \\
\text { Trunojoyo } \\
\text { Madura }\end{array}$ & $\begin{array}{l}\text { Usulan Baru } \\
\text { mulai Volume } 4 \\
\text { Nomor } 1 \text { Tahun } \\
2018\end{array}$ \\
\hline & 100 & $\begin{array}{l}\text { Jurnal Ilmiah } \\
\text { Penegakan Hukum }\end{array}$ & $2622061 X$ & $\begin{array}{l}\text { Universitas } \\
\text { Medan Area }\end{array}$ & $\begin{array}{l}\text { Reakreditasi } \\
\text { Tetap di } \\
\text { Peringkat } 5 \text { mulai } \\
\text { Volume } 6 \text { Nomor } \\
2 \text { Tahun } 2019\end{array}$ \\
\hline & 101 & $\begin{array}{l}\text { Jurnal Ilmiah } \\
\text { Teknik Mesin Al- } \\
\text { Jazari }\end{array}$ & 26150867 & $\begin{array}{l}\text { UPT Publikasi } \\
\text { dan Pengelolaan } \\
\text { Jurnal, } \\
\text { Universitas Islam } \\
\text { Kalimantan }\end{array}$ & $\begin{array}{l}\text { Usulan Baru } \\
\text { mulai Volume } 3 \\
\text { Nomor } 1 \text { Tahun } \\
2018\end{array}$ \\
\hline & 102 & $\begin{array}{l}\text { Jurnal Ilmu } \\
\text { Farmasi dan } \\
\text { Farmasi Klinik } \\
\text { (Journal of } \\
\text { Pharmaceutical } \\
\text { Science and Clinical } \\
\text { Pharmacy) }\end{array}$ & 27163814 & $\begin{array}{l}\text { Universitas } \\
\text { Wahid Hasyim } \\
\text { Semarang }\end{array}$ & $\begin{array}{l}\text { Usulan Baru } \\
\text { mulai Volume } 15 \\
\text { Nomor } 1 \text { Tahun } \\
2018\end{array}$ \\
\hline & 103 & $\begin{array}{l}\text { Jurnal Ilmu } \\
\text { Kesehatan Bhakti } \\
\text { Husada: Health } \\
\text { Science Journal }\end{array}$ & 26231204 & $\begin{array}{l}\text { Lembaga } \\
\text { Penelitian } \\
\text { Sekolah Tinggi } \\
\text { Ilmu Kesehatan } \\
\text { Kuningan } \\
\text { Garawangi } \\
\end{array}$ & $\begin{array}{l}\text { Usulan Baru } \\
\text { mulai Volume } 9 \\
\text { Nomor } 1 \text { Tahun } \\
2018\end{array}$ \\
\hline & 104 & $\begin{array}{l}\text { Jurnal Ilmu } \\
\text { Kesehatan Makia }\end{array}$ & 25499327 & $\begin{array}{l}\text { Lembaga } \\
\text { Penelitian dan } \\
\text { Pengabdian } \\
\text { Masyarakat } \\
\text { (LPPM) STIKes } \\
\text { Insan Cendekia } \\
\text { Husada } \\
\text { Bojonegoro }\end{array}$ & $\begin{array}{l}\text { Usulan Baru } \\
\text { mulai Volume } 6 \\
\text { Nomor } 1 \text { Tahun } \\
2018\end{array}$ \\
\hline & 105 & $\begin{array}{l}\text { Jurnal Imedtech } \\
\text { (Instructional Media, } \\
\text { Design and } \\
\text { Technology) }\end{array}$ & 25806033 & $\begin{array}{l}\text { P2M STKIP Citra } \\
\text { Bakti }\end{array}$ & $\begin{array}{l}\text { Usulan Baru } \\
\text { mulai Volume } 2 \\
\text { Nomor } 1 \text { Tahun } \\
2018\end{array}$ \\
\hline & 106 & $\begin{array}{l}\text { Jurnal Insan } \\
\text { Farmasi Indonesia }\end{array}$ & 26214032 & $\begin{array}{l}\text { Akademi Farmasi } \\
\text { ISFI Banjarmasin }\end{array}$ & $\begin{array}{l}\text { Usulan Baru } \\
\text { mulai Volume } 1 \\
\text { Nomor } 1 \text { Tahun } \\
2018\end{array}$ \\
\hline
\end{tabular}




\begin{tabular}{|c|c|c|c|c|c|}
\hline Peringkat & No. & Nama Jurnal & E-ISSN & Penerbit & Keterangan \\
\hline & 107 & Jurnal Investasi & 24424331 & $\begin{array}{l}\text { Universitas } \\
\text { Wiralodra }\end{array}$ & $\begin{array}{l}\text { Usulan Baru } \\
\text { mulai Volume } 4 \\
\text { Nomor } 1 \text { Tahun } \\
2018\end{array}$ \\
\hline & 108 & $\begin{array}{l}\text { Jurnal Kebidanan } \\
\text { Harapan Ibu } \\
\text { Pekalongan }\end{array}$ & 25795481 & $\begin{array}{l}\text { Akademi } \\
\text { Kebidanan } \\
\text { Harapan Ibu } \\
\text { Pekalongan }\end{array}$ & $\begin{array}{l}\text { Usulan Baru } \\
\text { mulai Volume } 3 \\
\text { Nomor } 1 \text { Tahun } \\
2018\end{array}$ \\
\hline & 109 & $\begin{array}{l}\text { Jurnal Keperawatan } \\
\text { Priority }\end{array}$ & 26144719 & $\begin{array}{l}\text { Universitas Prima } \\
\text { Indonesia }\end{array}$ & $\begin{array}{l}\text { Usulan Baru } \\
\text { mulai Volume } 1 \\
\text { Nomor } 1 \text { Tahun } \\
2018\end{array}$ \\
\hline & 110 & $\begin{array}{l}\text { Jurnal Kesehatan } \\
\text { Delima Pelamonia }\end{array}$ & 26848821 & $\begin{array}{l}\text { Akademi } \\
\text { Kebidanan } \\
\text { Pelamonia } \\
\text { Makassar }\end{array}$ & $\begin{array}{l}\text { Usulan Baru } \\
\text { mulai Volume } 2 \\
\text { Nomor } 1 \text { Tahun } \\
2018\end{array}$ \\
\hline & 111 & $\begin{array}{l}\text { Jurnal Kesehatan } \\
\text { Madani Medika }\end{array}$ & 26847345 & $\begin{array}{l}\text { Sekolah Tinggi } \\
\text { Ilmu Kesehatan } \\
\text { Madani }\end{array}$ & $\begin{array}{l}\text { Usulan Baru } \\
\text { mulai Volume } 9 \\
\text { Nomor } 1 \text { Tahun } \\
2018\end{array}$ \\
\hline & 112 & $\begin{array}{l}\text { Jurnal Kesehatan } \\
\text { Panrita Husada }\end{array}$ & 27151832 & $\begin{array}{l}\text { Stikes Panrita } \\
\text { Husada } \\
\text { Bulukumba }\end{array}$ & $\begin{array}{l}\text { Usulan Baru } \\
\text { mulai Volume } 3 \\
\text { Nomor } 1 \text { Tahun } \\
2018\end{array}$ \\
\hline & 113 & $\begin{array}{l}\text { Jurnal Maternitas } \\
\text { Kebidanan }\end{array}$ & 25991841 & $\begin{array}{l}\text { Universitas Prima } \\
\text { Indonesia }\end{array}$ & $\begin{array}{l}\text { Usulan Baru } \\
\text { mulai Volume } 3 \\
\text { Nomor } 1 \text { Tahun } \\
2018\end{array}$ \\
\hline & 114 & Jurnal Mediagro & 1562648712 & $\begin{array}{l}\text { Fakultas } \\
\text { Pertanian } \\
\text { Universitas } \\
\text { Wahid Hasyim }\end{array}$ & $\begin{array}{l}\text { Usulan Baru } \\
\text { mulai Volume } 13 \\
\text { Nomor } 2 \text { Tahun } \\
2017\end{array}$ \\
\hline & 115 & $\begin{array}{l}\text { Jurnal Medika } \\
\text { Cendikia }\end{array}$ & 24424412 & $\begin{array}{l}\text { STIKes Karsa } \\
\text { Husada Garut }\end{array}$ & $\begin{array}{l}\text { Usulan Baru } \\
\text { mulai Volume } 5 \\
\text { Nomor } 1 \text { Tahun } \\
2018\end{array}$ \\
\hline & 116 & Jurnal Mekanova & 25020498 & $\begin{array}{l}\text { Jurusan Teknik } \\
\text { Mesin Fakultas } \\
\text { Teknik } \\
\text { Universitas } \\
\text { Teuku Umar }\end{array}$ & $\begin{array}{l}\text { Usulan Baru } \\
\text { mulai Volume } 4 \\
\text { Nomor } 1 \text { Tahun } \\
2018\end{array}$ \\
\hline
\end{tabular}

117. Jurnal ... 


\begin{tabular}{|c|c|c|c|c|c|}
\hline Peringkat & No. & Nama Jurnal & E-ISSN & Penerbit & Keterangan \\
\hline & 117 & $\begin{array}{l}\text { Jurnal Middle East } \\
\text { and Islamic Studies } \\
\text { (MEIS) }\end{array}$ & $2685239 X$ & $\begin{array}{l}\text { Program Studi } \\
\text { Kajian Wilayah } \\
\text { Timur Tengah } \\
\text { dan Islam, } \\
\text { Sekolah Kajian } \\
\text { Stratejik dan } \\
\text { Global, } \\
\text { Universitas } \\
\text { Indonesia } \\
\end{array}$ & $\begin{array}{l}\text { Usulan Baru } \\
\text { mulai Volume } 5 \\
\text { Nomor } 1 \text { Tahun } \\
2018\end{array}$ \\
\hline & 118 & $\begin{array}{l}\text { Jurnal Mutiara } \\
\text { Akuntansi }\end{array}$ & 25797611 & $\begin{array}{l}\text { Program Studi } \\
\text { Ilmu Akuntansi } \\
\text { FEIS Universitas } \\
\text { Sari Mutiara } \\
\text { Indonesia } \\
\end{array}$ & $\begin{array}{l}\text { Usulan Baru } \\
\text { mulai Volume } 3 \\
\text { Nomor } 1 \text { Tahun } \\
2018\end{array}$ \\
\hline & 119 & Jurnal Optimalisasi & 25020501 & $\begin{array}{l}\text { Jurusan Teknik } \\
\text { Industri } \\
\text { Universitas } \\
\text { Teuku Umar }\end{array}$ & $\begin{array}{l}\text { Usulan Baru } \\
\text { mulai Volume } 4 \\
\text { Nomor } 1 \text { Tahun } \\
2018\end{array}$ \\
\hline & 120 & $\begin{array}{l}\text { Jurnal Pendidikan } \\
\text { dan Pembelajaran } \\
\text { Sains Indonesia } \\
\text { (JPPSI) }\end{array}$ & 26230852 & $\begin{array}{l}\text { Jurusan Fisika } \\
\text { dan Pengajaran } \\
\text { IPA Universitas } \\
\text { Pendidikan } \\
\text { Ganesha }\end{array}$ & $\begin{array}{l}\text { Usulan Baru } \\
\text { mulai Volume } 1 \\
\text { Nomor } 1 \text { Tahun } \\
2018\end{array}$ \\
\hline & 121 & $\begin{array}{l}\text { Jurnal Pendidikan } \\
\text { Luar Sekolah }\end{array}$ & 27153363 & $\begin{array}{l}\text { Universitas Ibn } \\
\text { Khaldun }\end{array}$ & $\begin{array}{l}\text { Usulan Baru } \\
\text { mulai Volume } 12 \\
\text { Nomor } 1 \text { Tahun } \\
2018\end{array}$ \\
\hline & 122 & $\begin{array}{l}\text { Jurnal Penelitian } \\
\text { Kebijakan } \\
\text { Pendidikan }\end{array}$ & $2654427 \mathrm{X}$ & $\begin{array}{l}\text { Kementerian } \\
\text { Pendidikan dan } \\
\text { Kebudayaan }\end{array}$ & $\begin{array}{l}\text { Usulan Baru } \\
\text { mulai Volume } 11 \\
\text { Nomor } 3 \text { Tahun } \\
2018\end{array}$ \\
\hline & 123 & $\begin{array}{l}\text { Jurnal Pengabdian } \\
\text { Masyarakat Ilmu } \\
\text { Keguruan dan } \\
\text { Pendidikan (JPM- } \\
\text { IKP) }\end{array}$ & 26147491 & $\begin{array}{l}\text { Fakultas } \\
\text { Keguruan dan } \\
\text { Ilmu Pendidikan } \\
\text { Universitas } \\
\text { Trilogi } \\
\end{array}$ & $\begin{array}{l}\text { Usulan Baru } \\
\text { mulai Volume } 1 \\
\text { Nomor } 1 \text { Tahun } \\
2018\end{array}$ \\
\hline & 124 & $\begin{array}{l}\text { Jurnal Pengabdian } \\
\text { Masyarakat MIPA } \\
\text { dan Pendidikan } \\
\text { MIPA }\end{array}$ & 25494899 & $\begin{array}{l}\text { Fakultas } \\
\text { Matematika dan } \\
\text { Ilmu } \\
\text { Pengetahuan } \\
\text { Alam Universitas } \\
\text { Negeri } \\
\text { Yogyakarta } \\
\end{array}$ & $\begin{array}{l}\text { Usulan Baru } \\
\text { mulai Volume } 2 \\
\text { Nomor } 1 \text { Tahun } \\
2018\end{array}$ \\
\hline & 125 & $\begin{array}{l}\text { Jurnal } \\
\text { Pengembangan } \\
\text { Wiraswasta }\end{array}$ & $2620388 \mathrm{X}$ & $\begin{array}{l}\text { LP2M Sekolah } \\
\text { Tinggi Ilmu } \\
\text { Ekonomi IPWI } \\
\text { Jakarta }\end{array}$ & $\begin{array}{l}\text { Usulan Baru } \\
\text { mulai Volume } 20 \\
\text { Nomor } 1 \text { Tahun } \\
2018\end{array}$ \\
\hline
\end{tabular}




\begin{tabular}{|c|c|c|c|c|c|}
\hline Peringkat & No. & Nama Jurnal & E-ISSN & Penerbit & Keterangan \\
\hline & 126 & Jurnal Raudhah & 27162435 & $\begin{array}{l}\text { Universitas Islam } \\
\text { Negeri Sumatera } \\
\text { Utara }\end{array}$ & $\begin{array}{l}\text { Usulan Baru } \\
\text { mulai Volume } 6 \\
\text { Nomor } 2 \text { Tahun } \\
2018\end{array}$ \\
\hline & 127 & $\begin{array}{l}\text { Jurnal Rekayasa } \\
\text { Konstruksi } \\
\text { Mekanika Sipil }\end{array}$ & 27151581 & $\begin{array}{l}\text { Universitas } \\
\text { Katolik Santo } \\
\text { Thomas }\end{array}$ & $\begin{array}{l}\text { Usulan Baru } \\
\text { mulai Volume } 1 \\
\text { Nomor } 1 \text { Tahun } \\
2018\end{array}$ \\
\hline & 128 & $\begin{array}{l}\text { Jurnal Riset } \\
\text { Akuntansi dan } \\
\text { Keuangan }\end{array}$ & 27158136 & $\begin{array}{l}\text { Universitas } \\
\text { Katolik Santo } \\
\text { Thomas }\end{array}$ & $\begin{array}{l}\text { Usulan Baru } \\
\text { mulai Volume } 4 \\
\text { Nomor } 1 \text { Tahun } \\
2018\end{array}$ \\
\hline & 129 & $\begin{array}{l}\text { Jurnal Riset Bisnis } \\
\text { dan Investasi }\end{array}$ & $2684706 \mathrm{X}$ & $\begin{array}{l}\text { Jurusan } \\
\text { Administrasi } \\
\text { Niaga, Politeknik } \\
\text { Negeri Bandung }\end{array}$ & $\begin{array}{l}\text { Usulan Baru } \\
\text { mulai Volume } 4 \\
\text { Nomor } 1 \text { Tahun } \\
2018\end{array}$ \\
\hline & 130 & $\begin{array}{l}\text { Jurnal Seni } \\
\text { Nasional Cikini }\end{array}$ & 27157482 & $\begin{array}{l}\text { Institut Kesenian } \\
\text { Jakarta }\end{array}$ & $\begin{array}{l}\text { Usulan Baru } \\
\text { mulai Volume } 3 \\
\text { Nomor } 3 \text { Tahun } \\
2018\end{array}$ \\
\hline & 131 & $\begin{array}{l}\text { Jurnal Sistem } \\
\text { Informasi } \\
\text { Universitas } \\
\text { Suryadarma }\end{array}$ & 25413228 & $\begin{array}{l}\text { Universitas } \\
\text { Dirgantara } \\
\text { Marsekal } \\
\text { Suryadarma }\end{array}$ & $\begin{array}{l}\text { Usulan Baru } \\
\text { mulai Volume } 5 \\
\text { Nomor } 2 \text { Tahun } \\
2018\end{array}$ \\
\hline & 132 & $\begin{array}{l}\text { Jurnal Speed (Sport, } \\
\text { Physical Education, } \\
\text { Empowerment) }\end{array}$ & 26216698 & $\begin{array}{l}\text { Universitas } \\
\text { Singaperbangsa } \\
\text { Karawang }\end{array}$ & $\begin{array}{l}\text { Usulan Baru } \\
\text { mulai Volume } 1 \\
\text { Nomor } 1 \text { Tahun } \\
2018\end{array}$ \\
\hline & 133 & $\begin{array}{l}\text { Jurnal STEI } \\
\text { Ekonomi }\end{array}$ & 25274783 & $\begin{array}{l}\text { Sekolah Tinggi } \\
\text { Ilmu Ekonomi } \\
\text { Indonesia } \\
\text { Jakarta }\end{array}$ & $\begin{array}{l}\text { Usulan Baru } \\
\text { mulai Volume } 27 \\
\text { Nomor } 1 \text { Tahun } \\
2018\end{array}$ \\
\hline & 134 & $\begin{array}{l}\text { Jurnal Studi } \\
\text { Manajemen dan } \\
\text { Bisnis }\end{array}$ & 24603775 & $\begin{array}{l}\text { Universitas } \\
\text { Trunojoyo } \\
\text { Madura }\end{array}$ & $\begin{array}{l}\text { Usulan Baru } \\
\text { mulai Volume } 5 \\
\text { Nomor } 1 \text { Tahun } \\
2018\end{array}$ \\
\hline & 135 & Jurnal Tahuri & 26854198 & $\begin{array}{l}\text { Universitas } \\
\text { Pattimura }\end{array}$ & $\begin{array}{l}\text { Usulan Baru } \\
\text { mulai Volume } 15 \\
\text { Nomor } 1 \text { Tahun } \\
2018\end{array}$ \\
\hline & 136 & Jurnal Talenta Sipil & 26151634 & $\begin{array}{l}\text { Program Studi } \\
\text { Teknik Sipil } \\
\text { Fakultas Teknik } \\
\text { Universitas } \\
\text { Batanghari }\end{array}$ & $\begin{array}{l}\text { Usulan Baru } \\
\text { mulai Volume } 1 \\
\text { Nomor } 1 \text { Tahun } \\
2018\end{array}$ \\
\hline
\end{tabular}




\begin{tabular}{|c|c|c|c|c|c|}
\hline Peringkat & No. & Nama Jurnal & E-ISSN & Penerbit & Keterangan \\
\hline & 137 & $\begin{array}{l}\text { Jurnal Teknik } \\
\text { Elektro Uniba (JTE } \\
\text { Uniba) }\end{array}$ & 25490842 & $\begin{array}{l}\text { Universitas } \\
\text { Balikpapan }\end{array}$ & $\begin{array}{l}\text { Usulan Baru } \\
\text { mulai Volume } 3 \\
\text { Nomor } 1 \text { Tahun } \\
2018\end{array}$ \\
\hline & 138 & $\begin{array}{l}\text { Jurnal Terapan } \\
\text { Abdimas }\end{array}$ & 25022784 & $\begin{array}{l}\text { Universitas PGRI } \\
\text { Madiun }\end{array}$ & $\begin{array}{l}\text { Reakreditasi } \\
\text { Tetap di } \\
\text { Peringkat } 5 \text { mulai } \\
\text { Volume } 5 \text { Nomor } \\
1 \text { Tahun } 2020 \\
\end{array}$ \\
\hline & 139 & Jurnal Teras Fisika & 26151219 & $\begin{array}{l}\text { Jurusan Fisika } \\
\text { Universitas } \\
\text { Jenderal } \\
\text { Soedirman }\end{array}$ & $\begin{array}{l}\text { Usulan Baru } \\
\text { mulai Volume } 1 \\
\text { Nomor } 1 \text { Tahun } \\
2018\end{array}$ \\
\hline & 140 & $\begin{array}{l}\text { Jutis (Jurnal Teknik } \\
\text { Informatika) }\end{array}$ & 26560860 & $\begin{array}{l}\text { Universitas Islam } \\
\text { Syekh Yusuf } \\
\text { Tangerang }\end{array}$ & $\begin{array}{l}\text { Usulan Baru } \\
\text { mulai Volume } 6 \\
\text { Nomor } 1 \text { Tahun } \\
2018\end{array}$ \\
\hline & 141 & $\begin{array}{l}\text { Kenosis: Jurnal } \\
\text { Kajian Teologi }\end{array}$ & 26564483 & $\begin{array}{l}\text { Institut Agama } \\
\text { Kristen Negeri } \\
\text { Ambon }\end{array}$ & $\begin{array}{l}\text { Usulan Baru } \\
\text { mulai Volume } 4 \\
\text { Nomor } 1 \text { Tahun } \\
2018\end{array}$ \\
\hline & 142 & $\begin{array}{l}\text { Kompak: Jurnal } \\
\text { Ilmiah } \\
\text { Komputerisasi } \\
\text { Akuntansi }\end{array}$ & 26216248 & $\begin{array}{l}\text { Pusat Penelitian } \\
\text { Sekolah Tinggi } \\
\text { Elektronika dan } \\
\text { Komputer } \\
\text { Semarang }\end{array}$ & $\begin{array}{l}\text { Usulan Baru } \\
\text { mulai Volume } 11 \\
\text { Nomor } 1 \text { Tahun } \\
2018\end{array}$ \\
\hline & 143 & $\begin{array}{l}\text { Legalitas: Jurnal } \\
\text { Hukum }\end{array}$ & 25978861 & $\begin{array}{l}\text { Pusat Penelitian } \\
\text { dan } \\
\text { Pengembangan } \\
\text { Hukum, Program } \\
\text { Magister Ilmu } \\
\text { Hukum, } \\
\text { Universitas } \\
\text { Batanghari } \\
\end{array}$ & $\begin{array}{l}\text { Usulan Baru } \\
\text { mulai Volume } 10 \\
\text { Nomor } 1 \text { Tahun } \\
2018\end{array}$ \\
\hline & 144 & $\begin{array}{l}\text { Lekesan: } \\
\text { Interdisciplinary } \\
\text { Journal of Asia } \\
\text { Pacific Arts }\end{array}$ & 25982192 & $\begin{array}{l}\text { Pusat Penerbitan } \\
\text { LP2MPP Institut } \\
\text { Seni Indonesia } \\
\text { Denpasar }\end{array}$ & $\begin{array}{l}\text { Usulan Baru } \\
\text { mulai Volume } 1 \\
\text { Nomor } 1 \text { Tahun } \\
2018\end{array}$ \\
\hline & 145 & $\begin{array}{l}\text { Madani Legal } \\
\text { Review }\end{array}$ & 25806319 & $\begin{array}{l}\text { Universitas } \\
\text { Muhammadiyah } \\
\text { Parepare }\end{array}$ & $\begin{array}{l}\text { Usulan Baru } \\
\text { mulai Volume } 2 \\
\text { Nomor } 1 \text { Tahun } \\
2018\end{array}$ \\
\hline
\end{tabular}

146. Mandala ... 


\begin{tabular}{|c|c|c|c|c|c|}
\hline \multirow[t]{11}{*}{ Peringkat } & No. & Nama Jurnal & E-ISSN & Penerbit & Keterangan \\
\hline & 146 & $\begin{array}{l}\text { Mandala: Jurnal } \\
\text { Ilmu Hubungan } \\
\text { Internasional }\end{array}$ & 25990675 & $\begin{array}{l}\text { Prodi Hubungan } \\
\text { Internasional, } \\
\text { Fakultas Ilmu } \\
\text { Sosial dan Ilmu } \\
\text { Politik, } \\
\text { Universitas } \\
\text { Pembangunan } \\
\text { Nasional Veteran } \\
\text { Jakarta }\end{array}$ & $\begin{array}{l}\text { Usulan Baru } \\
\text { mulai Volume } 1 \\
\text { Nomor } 1 \text { Tahun } \\
2018\end{array}$ \\
\hline & 147 & $\begin{array}{l}\text { Media Penelitian } \\
\text { Pendidikan: Jurnal } \\
\text { Penelitian dalam } \\
\text { Bidang Pendidikan } \\
\text { dan Pengajaran }\end{array}$ & 25280562 & $\begin{array}{l}\text { LPPM Universitas } \\
\text { PGRI Semarang }\end{array}$ & $\begin{array}{l}\text { Reakreditasi } \\
\text { Tetap di } \\
\text { Peringkat } 5 \text { mulai } \\
\text { Volume } 13 \\
\text { Nomor } 2 \text { Tahun } \\
2019\end{array}$ \\
\hline & 148 & $\begin{array}{l}\text { MetaKom: Jurnal } \\
\text { Kajian Komunikasi }\end{array}$ & 27150089 & $\begin{array}{l}\text { Universitas } \\
\text { Lampung }\end{array}$ & $\begin{array}{l}\text { Usulan Baru } \\
\text { mulai Volume } 2 \\
\text { Nomor } 1 \text { Tahun } \\
2018\end{array}$ \\
\hline & 149 & $\begin{array}{l}\text { Mizan: Jurnal Ilmu } \\
\text { Hukum }\end{array}$ & 26572494 & $\begin{array}{l}\text { Universitas Islam } \\
\text { Kadiri }\end{array}$ & $\begin{array}{l}\text { Usulan Baru } \\
\text { mulai Volume } 7 \\
\text { Nomor } 1 \text { Tahun } \\
2018\end{array}$ \\
\hline & 150 & $\begin{array}{l}\text { Mukadimah: Jurnal } \\
\text { Pendidikan, } \\
\text { Sejarah, dan Ilmu- } \\
\text { ilmu Sosial }\end{array}$ & 26221373 & $\begin{array}{l}\text { Program Studi } \\
\text { Pendidikan } \\
\text { Sejarah, FKIP, } \\
\text { Universitas Islam } \\
\text { Sumatera Utara }\end{array}$ & $\begin{array}{l}\text { Usulan Baru } \\
\text { mulai Volume } 2 \\
\text { Nomor } 2 \text { Tahun } \\
2018\end{array}$ \\
\hline & 151 & Nuansa Informatika & 26145405 & $\begin{array}{l}\text { Fakultas Ilmu } \\
\text { Komputer } \\
\text { Universitas } \\
\text { Kuningan }\end{array}$ & $\begin{array}{l}\text { Usulan Baru } \\
\text { mulai Volume } 12 \\
\text { Nomor } 1 \text { Tahun } \\
2018\end{array}$ \\
\hline & 152 & Nursing Arts & $2686133 X$ & $\begin{array}{l}\text { Jurusan } \\
\text { Keperawatan } \\
\text { Poltekkes } \\
\text { Kemenkes } \\
\text { Sorong } \\
\end{array}$ & $\begin{array}{l}\text { Usulan Baru } \\
\text { mulai Volume } 12 \\
\text { Nomor } 1 \text { Tahun } \\
2018\end{array}$ \\
\hline & 153 & $\begin{array}{l}\text { Paedagogia: Jurnal } \\
\text { Pendidikan }\end{array}$ & 25800477 & $\begin{array}{l}\text { Institut Agama } \\
\text { Islam Negeri Palu }\end{array}$ & $\begin{array}{l}\text { Usulan Baru } \\
\text { mulai Volume } 7 \\
\text { Nomor } 1 \text { Tahun } \\
2018\end{array}$ \\
\hline & 154 & $\begin{array}{l}\text { Paradigma } \\
\text { Polistaat: Jurnal } \\
\text { Ilmu Sosial dan } \\
\text { Ilmu Politik }\end{array}$ & 25793888 & $\begin{array}{l}\text { Universitas } \\
\text { Pasundan }\end{array}$ & $\begin{array}{l}\text { Usulan Baru } \\
\text { mulai Volume } 1 \\
\text { Nomor } 1 \text { Tahun } \\
2018\end{array}$ \\
\hline & 155 & $\begin{array}{l}\text { Pena Akuatika: } \\
\text { Jurnal Ilmiah } \\
\text { Perikanan dan } \\
\text { Kelautan }\end{array}$ & $2301640 X$ & $\begin{array}{l}\text { Universitas } \\
\text { Pekalongan }\end{array}$ & $\begin{array}{l}\text { Usulan Baru } \\
\text { mulai Volume } 17 \\
\text { Nomor } 1 \text { Tahun } \\
2018\end{array}$ \\
\hline
\end{tabular}




\begin{tabular}{|c|c|c|c|c|c|}
\hline \begin{tabular}{|l|} 
Peringkat \\
\end{tabular} & No. & Nama Jurnal & E-ISSN & Penerbit & Keterangan \\
\hline & 156 & Petitum & 27160017 & $\begin{array}{l}\text { Universitas } \\
\text { Indonesia Timur }\end{array}$ & $\begin{array}{l}\text { Usulan Baru } \\
\text { mulai Volume } 6 \\
\text { Nomor } 1 \text { Tahun } \\
2018\end{array}$ \\
\hline & 157 & $\begin{array}{l}\text { Pharmauho: Jurnal } \\
\text { Farmasi, Sains, dan } \\
\text { Kesehatan }\end{array}$ & 27154181 & $\begin{array}{l}\text { Universitas Halu } \\
\text { Oleo }\end{array}$ & $\begin{array}{l}\text { Usulan Baru } \\
\text { mulai Volume } 4 \\
\text { Nomor } 1 \text { Tahun } \\
2018\end{array}$ \\
\hline & 158 & $\begin{array}{l}\text { PHI: Jurnal } \\
\text { Pendidikan } \\
\text { Matematika }\end{array}$ & 25980661 & $\begin{array}{l}\text { Program Studi } \\
\text { Pendidikan } \\
\text { Matematika, } \\
\text { Fakultas } \\
\text { Keguruan dan } \\
\text { Ilmu Pendidikan } \\
\text { Universitas } \\
\text { Batanghari }\end{array}$ & $\begin{array}{l}\text { Usulan Baru } \\
\text { mulai Volume } 2 \\
\text { Nomor } 1 \text { Tahun } \\
2018\end{array}$ \\
\hline & 159 & $\begin{array}{l}\text { Piwulang Jawi: } \\
\text { Journal of Javanese } \\
\text { Learning and } \\
\text { Teaching }\end{array}$ & 22526307 & $\begin{array}{l}\text { Jurusan Bahasa } \\
\text { dan Sastra Jawa, } \\
\text { Fakultas Bahasa } \\
\text { dan Seni, } \\
\text { Universitas } \\
\text { Negeri Semarang }\end{array}$ & $\begin{array}{l}\text { Usulan Baru } \\
\text { mulai Volume } 6 \\
\text { Nomor } 1 \text { Tahun } \\
2018\end{array}$ \\
\hline & 160 & $\begin{array}{l}\text { Politea: Jurnal } \\
\text { Politik Islam }\end{array}$ & 27151166 & UIN Mataram & $\begin{array}{l}\text { Usulan Baru } \\
\text { mulai Volume } 1 \\
\text { Nomor } 1 \text { Tahun } \\
2018\end{array}$ \\
\hline & 161 & $\begin{array}{l}\text { PROFIT: Jurnal } \\
\text { Administrasi Bisnis }\end{array}$ & 23384654 & $\begin{array}{l}\text { Fakultas Ilmu } \\
\text { Administrasi } \\
\text { Universitas } \\
\text { Brawijaya }\end{array}$ & $\begin{array}{l}\text { Usulan Baru } \\
\text { mulai Volume } 12 \\
\text { Nomor } 1 \text { Tahun } \\
2018\end{array}$ \\
\hline & 162 & $\begin{array}{l}\text { Progressa: Journal } \\
\text { of Islamic Religious } \\
\text { Instruction }\end{array}$ & 25799673 & $\begin{array}{l}\text { STIT Raden } \\
\text { Wijaya Mojokerto }\end{array}$ & $\begin{array}{l}\text { Usulan Baru } \\
\text { mulai Volume } 2 \\
\text { Nomor } 1 \text { Tahun } \\
2018\end{array}$ \\
\hline & 163 & $\begin{array}{l}\text { Prokons: Jurnal } \\
\text { Teknik Sipil }\end{array}$ & 27148815 & $\begin{array}{l}\text { Politeknik Negeri } \\
\text { Malang, jurusan } \\
\text { teknik sipil }\end{array}$ & $\begin{array}{l}\text { Usulan Baru } \\
\text { mulai Volume } 12 \\
\text { Nomor } 1 \text { Tahun } \\
2018\end{array}$ \\
\hline & 164 & $\begin{array}{l}\text { Promosi: Jurnal } \\
\text { Program Studi } \\
\text { Pendidikan } \\
\text { Ekonomi }\end{array}$ & 24429449 & $\begin{array}{l}\text { Universitas } \\
\text { Muhammadiyah } \\
\text { Metro }\end{array}$ & $\begin{array}{l}\text { Reakreditasi } \\
\text { Tetap di } \\
\text { Peringkat } 5 \text { mulai } \\
\text { Volume } 6 \text { Nomor } \\
1 \text { Tahun } 2018\end{array}$ \\
\hline & 165 & Prosodi & 26220474 & $\begin{array}{l}\text { Universitas } \\
\text { Trunojoyo } \\
\text { Madura }\end{array}$ & $\begin{array}{l}\text { Usulan Baru } \\
\text { mulai Volume } 12 \\
\text { Nomor } 1 \text { Tahun } \\
2018\end{array}$ \\
\hline
\end{tabular}

166. Psikodidaktika ... 


\begin{tabular}{|c|c|c|c|c|c|}
\hline Peringkat & No. & Nama Jurnal & E-ISSN & Penerbit & Keterangan \\
\hline & 166 & $\begin{array}{l}\text { Psikodidaktika: } \\
\text { Jurnal Ilmu } \\
\text { Pendidikan, } \\
\text { Psikologi, } \\
\text { Bimbingan dan } \\
\text { Konseling } \\
\end{array}$ & 26153297 & $\begin{array}{l}\text { Universitas Prof } \\
\text { Dr Hazairin SH }\end{array}$ & $\begin{array}{l}\text { Usulan Baru } \\
\text { mulai Volume } 3 \\
\text { Nomor } 1 \text { Tahun } \\
2018\end{array}$ \\
\hline & 167 & $\begin{array}{l}\text { Publica: Jurnal } \\
\text { Pemikiran } \\
\text { Administrasi Negara }\end{array}$ & 27159256 & $\begin{array}{l}\text { Universitas Islam } \\
\text { Negeri Sunan } \\
\text { Gunung Djati } \\
\text { Bandung }\end{array}$ & $\begin{array}{l}\text { Usulan Baru } \\
\text { mulai Volume } 10 \\
\text { Nomor } 1 \text { Tahun } \\
2018\end{array}$ \\
\hline & 168 & $\begin{array}{l}\text { Rawa Sains: Jurnal } \\
\text { Sains STIPER } \\
\text { Amuntai }\end{array}$ & 26863510 & $\begin{array}{l}\text { Sekolah Tinggi } \\
\text { Ilmu Pertanian } \\
\text { Amuntai }\end{array}$ & $\begin{array}{l}\text { Usulan Baru } \\
\text { mulai Volume } 8 \\
\text { Nomor } 1 \text { Tahun } \\
2018\end{array}$ \\
\hline & 169 & Rayah A1-Islam & 26862018 & STIBA Arraayah & $\begin{array}{l}\text { Usulan Baru } \\
\text { mulai Volume } 2 \\
\text { Nomor } 1 \text { Tahun } \\
2018\end{array}$ \\
\hline & 170 & $\begin{array}{l}\text { Research Journal of } \\
\text { Accounting and } \\
\text { Business } \\
\text { Management }\end{array}$ & 25803131 & $\begin{array}{l}\text { Universitas } 17 \\
\text { Agustus } 1945 \\
\text { Samarinda }\end{array}$ & $\begin{array}{l}\text { Usulan Baru } \\
\text { mulai Volume } 2 \\
\text { Nomor } 1 \text { Tahun } \\
2018\end{array}$ \\
\hline & 171 & $\begin{array}{l}\text { Saintek: Jurnal } \\
\text { ilmiah Sains dan } \\
\text { Teknologi Industri }\end{array}$ & 25978586 & $\begin{array}{l}\text { Universitas } \\
\text { Katolik Musi } \\
\text { Charitas }\end{array}$ & $\begin{array}{l}\text { Usulan Baru } \\
\text { mulai Volume } 2 \\
\text { Nomor } 1 \text { Tahun } \\
2018\end{array}$ \\
\hline & 172 & $\begin{array}{l}\text { Santhet: Jurnal } \\
\text { Sejarah, Pendidikan } \\
\text { dan Humaniora }\end{array}$ & 25416103 & $\begin{array}{l}\text { Universitas PGRI } \\
\text { Banyuwangi }\end{array}$ & $\begin{array}{l}\text { Usulan Baru } \\
\text { mulai Volume } 2 \\
\text { Nomor } 1 \text { Tahun } \\
2018\end{array}$ \\
\hline & 173 & $\begin{array}{l}\text { ScientiCO: Computer } \\
\text { Science and } \\
\text { Informatics Journal }\end{array}$ & 26204118 & $\begin{array}{l}\text { Universitas } \\
\text { Tadulako }\end{array}$ & $\begin{array}{l}\text { Usulan Baru } \\
\text { mulai Volume } 1 \\
\text { Nomor } 1 \text { Tahun } \\
2018\end{array}$ \\
\hline & 174 & $\begin{array}{l}\text { Selaparang: Jurnal } \\
\text { Pengabdian } \\
\text { Masyarakat } \\
\text { Berkemajuan }\end{array}$ & $2614526 \mathrm{X}$ & $\begin{array}{l}\text { Program Studi } \\
\text { Pendidikan } \\
\text { Fisika } \\
\text { Universitas } \\
\text { Muhammadiyah } \\
\text { Mataram } \\
\text { Mataram }\end{array}$ & $\begin{array}{l}\text { Usulan Baru } \\
\text { mulai Volume } 1 \\
\text { Nomor } 2 \text { Tahun } \\
2018\end{array}$ \\
\hline & 175 & $\begin{array}{l}\text { Serat Rupa Journal } \\
\text { of Design }\end{array}$ & $2477586 \mathrm{X}$ & $\begin{array}{l}\text { Universitas } \\
\text { Kristen } \\
\text { Maranatha }\end{array}$ & $\begin{array}{l}\text { Usulan Baru } \\
\text { mulai Volume } 2 \\
\text { Nomor } 2 \text { Tahun } \\
2018\end{array}$ \\
\hline & 176 & $\begin{array}{l}\text { SIMAK: Jurnal } \\
\text { Sistem Informasi, } \\
\text { Manajemen, dan } \\
\text { Akuntansi }\end{array}$ & 26210320 & $\begin{array}{l}\text { Universitas Atma } \\
\text { Jaya Makassar }\end{array}$ & $\begin{array}{l}\text { Usulan Baru } \\
\text { mulai Volume } 16 \\
\text { Nomor } 1 \text { Tahun } \\
2018\end{array}$ \\
\hline
\end{tabular}




\begin{tabular}{|c|c|c|c|c|c|}
\hline Peringkat & No. & Nama Jurnal & E-ISSN & Penerbit & Keterangan \\
\hline & 177 & $\begin{array}{l}\text { Sorai: Jurnal } \\
\text { Pengkajian dan } \\
\text { Penciptaan Musik }\end{array}$ & 26849445 & $\begin{array}{l}\text { Institut Seni } \\
\text { Indonesia } \\
\text { Surakarta }\end{array}$ & $\begin{array}{l}\text { Usulan Baru } \\
\text { mulai Volume } 11 \\
\text { Nomor } 1 \text { Tahun } \\
2018\end{array}$ \\
\hline & 178 & $\begin{array}{l}\text { Specta Journal of } \\
\text { Technology }\end{array}$ & 26229099 & $\begin{array}{l}\text { LPPM Institut } \\
\text { Teknologi } \\
\text { Kalimantan }\end{array}$ & $\begin{array}{l}\text { Usulan Baru } \\
\text { mulai Volume } 1 \\
\text { Nomor } 3 \text { Tahun } \\
2017\end{array}$ \\
\hline & 179 & $\begin{array}{l}\text { Ta Limuna: Jurnal } \\
\text { Pendidikan Islam }\end{array}$ & 20852975 & $\begin{array}{l}\text { STAI Ma'had Aly } \\
\text { Al Hikam Malang }\end{array}$ & $\begin{array}{l}\text { Usulan Baru } \\
\text { mulai Volume } 7 \\
\text { Nomor } 1 \text { Tahun } \\
2018\end{array}$ \\
\hline & 180 & $\begin{array}{l}\text { Tahdis: Jurnal } \\
\text { Kajian Ilmu Al- } \\
\text { Hadis }\end{array}$ & 27162109 & $\begin{array}{l}\text { Universitas Islam } \\
\text { Negeri Alauddin } \\
\text { Makassar }\end{array}$ & $\begin{array}{l}\text { Usulan Baru } \\
\text { mulai Volume } 9 \\
\text { Nomor } 1 \text { Tahun } \\
2018\end{array}$ \\
\hline & 181 & $\begin{array}{l}\text { Techno Xplore: } \\
\text { Jurnal Ilmu } \\
\text { Komputer dan } \\
\text { Teknologi Informasi }\end{array}$ & 25809288 & $\begin{array}{l}\text { Universitas } \\
\text { Buana } \\
\text { Perjuangan } \\
\text { Karawang }\end{array}$ & $\begin{array}{l}\text { Usulan Baru } \\
\text { mulai Volume } 3 \\
\text { Nomor } 1 \text { Tahun } \\
2018\end{array}$ \\
\hline & 182 & $\begin{array}{l}\text { Jurnal Teknik } \\
\text { Teknika }\end{array}$ & 26865416 & $\begin{array}{l}\text { Universitas IBA } \\
\text { Palembang }\end{array}$ & $\begin{array}{l}\text { Usulan Baru } \\
\text { mulai Volume } 13 \\
\text { Nomor } 1 \text { Tahun } \\
2018\end{array}$ \\
\hline & 183 & Teknika & 25808478 & $\begin{array}{l}\text { Program Studi } \\
\text { Teknik Sipil, } \\
\text { Fakultas Teknik, } \\
\text { Universitas } \\
\text { Semarang }\end{array}$ & $\begin{array}{l}\text { Usulan Baru } \\
\text { mulai Volume } 5 \\
\text { Nomor } 1 \text { Tahun } \\
2018\end{array}$ \\
\hline & 184 & $\begin{array}{l}\text { To Maega: Jurnal } \\
\text { Pengabdian } \\
\text { Masyarakat }\end{array}$ & 26226340 & $\begin{array}{l}\text { Universitas Andi } \\
\text { Djemma Palopo }\end{array}$ & $\begin{array}{l}\text { Usulan Baru } \\
\text { mulai Volume } 1 \\
\text { Nomor } 1 \text { Tahun } \\
2018\end{array}$ \\
\hline & 185 & $\begin{array}{l}\text { Transborders: } \\
\text { International } \\
\text { Relations Journal }\end{array}$ & 25989200 & $\begin{array}{l}\text { Jurusan } \\
\text { Hubungan } \\
\text { Internasional } \\
\text { FISIP Universitas } \\
\text { Pasundan } \\
\end{array}$ & $\begin{array}{l}\text { Usulan Baru } \\
\text { mulai Volume } 1 \\
\text { Nomor } 1 \text { Tahun } \\
2017\end{array}$ \\
\hline & 186 & UMI Medical Journal & 26857561 & $\begin{array}{l}\text { Universitas } \\
\text { Muslim } \\
\text { Indonesia }\end{array}$ & $\begin{array}{l}\text { Usulan Baru } \\
\text { mulai Volume } 3 \\
\text { Nomor } 1 \text { Tahun } \\
2018\end{array}$ \\
\hline & 187 & Untag Law Review & 25494910 & $\begin{array}{l}\text { Fakultas Hukum } \\
\text { Universitas } 17 \\
\text { Agustus } 1945 \\
\text { Semarang }\end{array}$ & $\begin{array}{l}\text { Usulan Baru } \\
\text { mulai Volume } 2 \\
\text { Nomor } 1 \text { Tahun } \\
2018\end{array}$ \\
\hline
\end{tabular}




\begin{tabular}{|c|c|c|c|c|c|}
\hline Peringkat & No. & Nama Jurnal & E-ISSN & Penerbit & Keterangan \\
\hline & 188 & $\begin{array}{l}\text { Vidya Wertta: Media } \\
\text { Komunikasi } \\
\text { Universitas Hindu } \\
\text { Indonesia }\end{array}$ & 26557282 & $\begin{array}{l}\text { Universitas } \\
\text { Hindu Indonesia }\end{array}$ & $\begin{array}{l}\text { Usulan Baru } \\
\text { mulai Volume } 1 \\
\text { Nomor } 2 \text { Tahun } \\
2018\end{array}$ \\
\hline & 189 & $\begin{array}{l}\text { Viva Medika: Jurnal } \\
\text { Kesehatan, } \\
\text { Kebidanan dan } \\
\text { Keperawatan }\end{array}$ & 26561034 & $\begin{array}{l}\text { Universitas } \\
\text { Harapan Bangsa } \\
\text { Banyumas }\end{array}$ & $\begin{array}{l}\text { Usulan Baru } \\
\text { mulai Volume } 1 \\
\text { Nomor } 1 \text { Tahun } \\
2018\end{array}$ \\
\hline & 190 & Widya Teknik & 26213362 & $\begin{array}{l}\text { Unika Widya } \\
\text { Mandala } \\
\text { Surabaya }\end{array}$ & $\begin{array}{l}\text { Usulan Baru } \\
\text { mulai Volume } 17 \\
\text { Nomor } 1 \text { Tahun } \\
2018\end{array}$ \\
\hline & 191 & $\begin{array}{l}\text { Widyadari: Jurnal } \\
\text { Pendidikan }\end{array}$ & 26139308 & $\begin{array}{l}\text { LPPM IKIP PGRI } \\
\text { Bali }\end{array}$ & $\begin{array}{l}\text { Usulan Baru } \\
\text { mulai Volume } 19 \\
\text { Nomor } 1 \text { Tahun } \\
2018\end{array}$ \\
\hline \multirow[t]{6}{*}{6} & $\overline{1}$ & $\begin{array}{l}\text { Akbis: Media Riset } \\
\text { Akuntansi dan } \\
\text { Bisnis }\end{array}$ & 26555050 & $\begin{array}{l}\text { Prodi Akuntansi } \\
\text { Fakultas } \\
\text { Ekonomi } \\
\text { Universitas } \\
\text { Teuku Umar }\end{array}$ & $\begin{array}{l}\text { Usulan Baru } \\
\text { mulai Volume } 2 \\
\text { Nomor } 1 \text { Tahun } \\
2018\end{array}$ \\
\hline & 2 & Ekonomi Bisnis & 27151662 & $\begin{array}{l}\text { Fakultas } \\
\text { Ekonomi dan } \\
\text { Bisnis } \\
\text { Universitas Islam } \\
\text { Syekh Yusuf } \\
\text { Tangerang } \\
\end{array}$ & $\begin{array}{l}\text { Usulan Baru } \\
\text { mulai Volume } 24 \\
\text { Nomor } 1 \text { Tahun } \\
2018\end{array}$ \\
\hline & $\overline{3}$ & Inovish Journal & 25283804 & $\begin{array}{l}\text { Politeknik Negeri } \\
\text { Bengkalis }\end{array}$ & $\begin{array}{l}\text { Usulan Baru } \\
\text { mulai Volume } 3 \\
\text { Nomor } 1 \text { Tahun } \\
2018\end{array}$ \\
\hline & 4 & $\begin{array}{l}\text { International } \\
\text { Journal of } \\
\text { Education, } \\
\text { Information } \\
\text { Technology, and } \\
\text { Others } \\
\end{array}$ & 26542528 & $\begin{array}{l}\text { Fakultas Ilmu } \\
\text { Pendidikan } \\
\text { Universitas Bumi } \\
\text { Hijrah }\end{array}$ & $\begin{array}{l}\text { Usulan Baru } \\
\text { mulai Volume } 1 \\
\text { Nomor } 1 \text { Tahun } \\
2018\end{array}$ \\
\hline & 5 & $\begin{array}{l}\text { Ius Civile: Refleksi } \\
\text { Penegakan Hukum } \\
\text { dan Keadilan }\end{array}$ & 26206617 & $\begin{array}{l}\text { Universitas } \\
\text { Teuku Umar }\end{array}$ & $\begin{array}{l}\text { Usulan Baru } \\
\text { mulai Volume } 2 \\
\text { Nomor } 1 \text { Tahun } \\
2018\end{array}$ \\
\hline & $\overline{6}$ & $\begin{array}{l}\text { Journal of English } \\
\text { Language and } \\
\text { Education }\end{array}$ & 25976850 & $\begin{array}{l}\text { Program Studi } \\
\text { Pendidikan } \\
\text { Bahasa Inggris } \\
\text { Universitas } \\
\text { Pahlawan } \\
\text { Tuanku } \\
\text { Tambusai }\end{array}$ & $\begin{array}{l}\text { Usulan Baru } \\
\text { mulai Volume } 3 \\
\text { Nomor } 1 \text { Tahun } \\
2018\end{array}$ \\
\hline
\end{tabular}




\begin{tabular}{|c|c|c|c|c|c|}
\hline Peringkat & No. & Nama Jurnal & E-ISSN & Penerbit & Keterangan \\
\hline & 7 & $\begin{array}{l}\text { Jurma: Jurnal } \\
\text { Program Mahasiswa } \\
\text { Kreatif }\end{array}$ & 26158019 & $\begin{array}{l}\text { LPPM Universitas } \\
\text { Ibn Khaldun } \\
\text { Bogor }\end{array}$ & $\begin{array}{l}\text { Usulan Baru } \\
\text { mulai Volume } 2 \\
\text { Nomor } 1 \text { Tahun } \\
2018\end{array}$ \\
\hline & 8 & $\begin{array}{l}\text { Jurnal Akuakultura } \\
\text { Universitas Teuku } \\
\text { Umar }\end{array}$ & 26207397 & $\begin{array}{l}\text { Universitas } \\
\text { Teuku Umar }\end{array}$ & $\begin{array}{l}\text { Usulan Baru } \\
\text { mulai Volume } 2 \\
\text { Nomor } 1 \text { Tahun } \\
2018\end{array}$ \\
\hline & 9 & $\begin{array}{l}\text { Jurnal Desain Idea: } \\
\text { Jurnal Desain } \\
\text { Produk Industri } \\
\text { Institut Teknologi } \\
\text { Sepuluh Nopember } \\
\text { Surabaya }\end{array}$ & 25800264 & $\begin{array}{l}\text { Pusat Publikasi } \\
\text { Ilmiah LPPM } \\
\text { Institut Teknologi } \\
\text { Sepuluh } \\
\text { November }\end{array}$ & $\begin{array}{l}\text { Usulan Baru } \\
\text { mulai Volume } 17 \\
\text { Nomor } 1 \text { Tahun } \\
2018\end{array}$ \\
\hline & 10 & Jurnal Idea Hukum & 24427241 & $\begin{array}{l}\text { Program Studi } \\
\text { Magister Hukum, } \\
\text { Fakultas Hukum } \\
\text { Universitas } \\
\text { Jenderal } \\
\text { Soedirman }\end{array}$ & $\begin{array}{l}\text { Usulan Baru } \\
\text { mulai Volume } 4 \\
\text { Nomor } 1 \text { Tahun } \\
2018\end{array}$ \\
\hline & 11 & $\begin{array}{l}\text { Jurnal Ilmiah } \\
\text { Aquinas }\end{array}$ & 27146472 & $\begin{array}{l}\text { Universitas } \\
\text { Katolik Santo } \\
\text { Thomas } \\
\text { Sumatera Utara }\end{array}$ & $\begin{array}{l}\text { Usulan Baru } \\
\text { mulai Volume } 1 \\
\text { Nomor } 2 \text { Tahun } \\
2018\end{array}$ \\
\hline & 12 & $\begin{array}{l}\text { Jurnal Ilmiah Ilmu } \\
\text { dan Teknologi } \\
\text { Rekayasa }\end{array}$ & 26150387 & $\begin{array}{l}\text { Pusat Penelitian } \\
\text { dan Pengabdian } \\
\text { Kepada } \\
\text { Masyarakat } \\
\text { Politeknik Negeri } \\
\text { Subang }\end{array}$ & $\begin{array}{l}\text { Usulan Baru } \\
\text { mulai Volume } 1 \\
\text { Nomor } 1 \text { Tahun } \\
2018\end{array}$ \\
\hline & 13 & $\begin{array}{l}\text { Jurnal Ilmiah } \\
\text { Sosiologi Agama } \\
\text { (JISA) }\end{array}$ & 26208059 & $\begin{array}{l}\text { Prodi Sosiologi } \\
\text { Agama Fakultas } \\
\text { Ilmu Sosial UIN } \\
\text { Sumatera Utara }\end{array}$ & $\begin{array}{l}\text { Usulan Baru } \\
\text { mulai Volume } 1 \\
\text { Nomor } 1 \text { Tahun } \\
2018\end{array}$ \\
\hline & 14 & $\begin{array}{l}\text { Jurnal Ilmu } \\
\text { Komputer dan } \\
\text { Bisnis }\end{array}$ & 25989715 & $\begin{array}{l}\text { Sekolah Tinggi } \\
\text { Manajemen } \\
\text { Informatika Dan } \\
\text { Komputer } \\
\text { Dharmapala Riau }\end{array}$ & $\begin{array}{l}\text { Usulan Baru } \\
\text { mulai Volume } 9 \\
\text { Nomor } 1 \text { Tahun } \\
2018\end{array}$ \\
\hline & 15 & $\begin{array}{l}\text { Jurnal Ilmu } \\
\text { Pendidikan } \\
\text { Ahlussunnah }\end{array}$ & 26208458 & $\begin{array}{l}\text { Sekolah Tinggi } \\
\text { Keguruan dan } \\
\text { Ilmu Pendidikan } \\
\text { Ahlussunnah }\end{array}$ & $\begin{array}{l}\text { Usulan Baru } \\
\text { mulai Volume } 1 \\
\text { Nomor } 1 \text { Tahun } \\
2018\end{array}$ \\
\hline & 16 & $\begin{array}{l}\text { Jurnal Kacapuri: } \\
\text { Jurnal Keilmuan } \\
\text { Teknik Sipil }\end{array}$ & 26566001 & $\begin{array}{l}\text { Universitas Islam } \\
\text { Kalimantan } \\
\text { Muhammad } \\
\text { Aryad Al-Banjari }\end{array}$ & $\begin{array}{l}\text { Usulan Baru } \\
\text { mulai Volume } 1 \\
\text { Nomor } 1 \text { Tahun } \\
2018\end{array}$ \\
\hline
\end{tabular}




\begin{tabular}{|c|c|c|c|c|c|}
\hline Peringkat & No. & Nama Jurnal & E-ISSN & Penerbit & Keterangan \\
\hline & 17 & $\begin{array}{l}\text { Jurnal Online } \\
\text { Keperawatan } \\
\text { Indonesia }\end{array}$ & 26212161 & $\begin{array}{l}\text { Universitas Sari } \\
\text { Mutiara } \\
\text { Indonesia }\end{array}$ & $\begin{array}{l}\text { Usulan Baru } \\
\text { mulai Volume } 1 \\
\text { Nomor } 1 \text { Tahun } \\
2018\end{array}$ \\
\hline & 18 & $\begin{array}{l}\text { Jurnal Pamator: } \\
\text { Jurnal Ilmiah } \\
\text { Universitas } \\
\text { Trunojoyo Madura }\end{array}$ & 26547856 & $\begin{array}{l}\text { Universitas } \\
\text { Trunojoyo } \\
\text { Madura }\end{array}$ & $\begin{array}{l}\text { Usulan Baru } \\
\text { mulai Volume } 11 \\
\text { Nomor } 1 \text { Tahun } \\
2018\end{array}$ \\
\hline & 19 & $\begin{array}{l}\text { Jurnal Pendidikan } \\
\text { Matematika Unila }\end{array}$ & $2715856 \mathrm{X}$ & $\begin{array}{l}\text { Universitas } \\
\text { Lampung }\end{array}$ & $\begin{array}{l}\text { Usulan Baru } \\
\text { mulai Volume } 6 \\
\text { Nomor } 1 \text { Tahun } \\
2018\end{array}$ \\
\hline & 20 & $\begin{array}{l}\text { Jurnal Pendidikan } \\
\text { Modern }\end{array}$ & $2580099 X$ & $\begin{array}{l}\text { LPPM STKIP } \\
\text { Modern Ngawi }\end{array}$ & $\begin{array}{l}\text { Usulan Baru } \\
\text { mulai Volume } 3 \\
\text { Nomor } 2 \text { Tahun } \\
2018\end{array}$ \\
\hline & 21 & $\begin{array}{l}\text { Jurnal Riset } \\
\text { Pendidikan } \\
\text { Ekonomi }\end{array}$ & 25409247 & $\begin{array}{l}\text { Fakultas } \\
\text { Ekonomika dan } \\
\text { Bisnis, } \\
\text { Universitas } \\
\text { Kanjuruhan } \\
\text { Malang }\end{array}$ & $\begin{array}{l}\text { Usulan Baru } \\
\text { mulai Volume } 3 \\
\text { Nomor } 1 \text { Tahun } \\
2018\end{array}$ \\
\hline & 22 & $\begin{array}{l}\text { Jurnal Seni } \\
\text { Makalangan }\end{array}$ & 27148920 & $\begin{array}{l}\text { Institut Seni } \\
\text { Budaya } \\
\text { Indonesia } \\
\text { Bandung }\end{array}$ & $\begin{array}{l}\text { Usulan Baru } \\
\text { mulai Volume } 5 \\
\text { Nomor } 1 \text { Tahun } \\
2018\end{array}$ \\
\hline & 23 & $\begin{array}{l}\text { Jurnal Teknologi } \\
\text { Technoscientia }\end{array}$ & 27148025 & $\begin{array}{l}\text { Institut Sains \& } \\
\text { Teknologi } \\
\text { AKPRIND } \\
\text { Yogyakarta }\end{array}$ & $\begin{array}{l}\text { Usulan Baru } \\
\text { mulai Volume } 10 \\
\text { Nomor } 2 \text { Tahun } \\
2018\end{array}$ \\
\hline & 24 & $\begin{array}{l}\text { Maha Widya } \\
\text { Bhuwana: Jurnal } \\
\text { Pendidikan, Agama } \\
\text { dan Budaya }\end{array}$ & 26544903 & $\begin{array}{l}\text { STAHN Mpu } \\
\text { Kuturan } \\
\text { Singaraja }\end{array}$ & $\begin{array}{l}\text { Usulan Baru } \\
\text { mulai Volume } 1 \\
\text { Nomor } 1 \text { Tahun } \\
2018\end{array}$ \\
\hline & 25 & Maleo Law Journal & 25805835 & $\begin{array}{l}\text { Fakultas Hukum } \\
\text { Universitas } \\
\text { Muhammadiyah } \\
\text { Palu }\end{array}$ & $\begin{array}{l}\text { Usulan Baru } \\
\text { mulai Volume } 2 \\
\text { Nomor } 1 \text { Tahun } \\
2018\end{array}$ \\
\hline & 26 & $\begin{array}{l}\text { Media Manajemen } \\
\text { Jasa }\end{array}$ & 25023632 & $\begin{array}{l}\text { Universitas } 17 \\
\text { Agustus } 1945 \\
\text { Jakarta }\end{array}$ & $\begin{array}{l}\text { Usulan Baru } \\
\text { mulai Volume } 6 \\
\text { Nomor } 1 \text { Tahun } \\
2018\end{array}$ \\
\hline & 27 & $\begin{array}{l}\text { Pixel: Jurnal Ilmiah } \\
\text { Komputer Grafis }\end{array}$ & 26216256 & $\begin{array}{l}\text { Sekolah Tinggi } \\
\text { Elektronika dan } \\
\text { Komputer }\end{array}$ & $\begin{array}{l}\text { Usulan Baru } \\
\text { mulai Volume } 11 \\
\text { Nomor } 1 \text { Tahun } \\
2018\end{array}$ \\
\hline
\end{tabular}




\begin{tabular}{|r|r|l|c|l|l|}
\hline Peringkat & No. & \multicolumn{1}{|c|}{ Nama Jurnal } & E-ISSN & \multicolumn{1}{c|}{ Penerbit } & \multicolumn{1}{c|}{ Keterangan } \\
\hline & 28 & $\begin{array}{l}\text { Riyadhoh: Jurnal } \\
\text { Pendidikan } \\
\text { Olahraga }\end{array}$ & 26562936 & $\begin{array}{l}\text { UPT Publikasi } \\
\text { dan Pengelolaan } \\
\text { Jurnal, } \\
\text { Universitas Islam } \\
\text { Kalimantan }\end{array}$ & $\begin{array}{l}\text { Usulan Baru } \\
\text { mulai Volume 1 } \\
\text { Nomor 1 Tahun } \\
2018\end{array}$ \\
& 29 & $\begin{array}{l}\text { Unistek: Jurnal } \\
\text { Pendidikan dan } \\
\text { Aplikasi Industri }\end{array}$ & 27160416 & $\begin{array}{l}\text { Universitas Islam } \\
\text { Syekh Yusuf } \\
\text { Tangerang }\end{array}$ & $\begin{array}{l}\text { Usulan Baru } \\
\text { mulai Volume 5 } \\
\text { Nomor 1 Tahun } \\
\text { 2018 }\end{array}$ \\
\hline
\end{tabular}

MENTERI RISET DAN TEKNOLOGI/

KEPALA BADAN RISET DAN INOVASI NASIONAL REPUBLIK INDONESIA,

ttd.

BAMBANG P.S. BRODJONEGORO

Salinan sesuai dengan aslinya KEMENTERIAN RISET DAN TEKNOLOGI/ BADAN RISET DAN INOVASI NASIONAL Sekretariat Kementerian/Sekretariat Utama oGI/B 柏

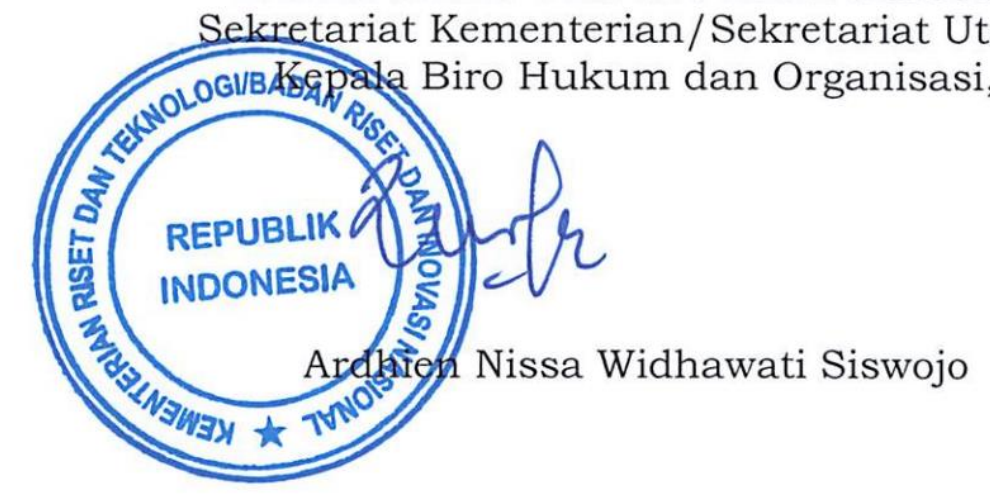

